\title{
STRUCTURAL CHANGES IN AGRICULTURE SINCE EU ACCESSION IN SLOVAKIA, THE CZECH REPUBLIC AND \\ HUNGARY
}


Editor:

Reviewed by:

Proofreader:

Editor-in-Chief:

Editorial Board:
Szabolcs Biró

prof. dr. Eleonóra Marišová,

Slovak University of Agriculture in Nitra,

Faculty of European Studies and Regional Development,

Nitra, Slovakia

prof. dr. András Nábrádi,

University Of Debrecen,

Faculty of Economics and Business,

Debrecen, Hungary

Andrew Fieldsend

Anikó Juhász

Szabolcs Biró

Károly Dublecz

János Felföldi

Imre Fertő

Miklós Herdon

Csaba Illés B.

István Kapronczai

József Káposzta

Gábor Kemény

Róbert Kertész

Szilárd Keszthelyi
Ibolya Lámfalusi

Károly Pető

Norbert Potori

László Rieger

Ildikó Stummer

Zoltán Szakály

István Szücs

István Takács

József Tóth

Szabolcs Vágó
Tamás Tóth

Publisher:

Research Institute of Agricultural Economics

H-1093 Budapest, Zsil utca 3-5.

Mailing address: H-1463 Budapest, Pf:: 944

Telephone: (+36 1) 217-1011

Fax: (+36 1) 217-4469

www.aki.gov.hu

aki@aki.gov.hu

DOI: http://dx.doi.org/10.7896/ak1702

ISBN 978-963-491-594-2

ISSN 2061-8204 (Agricultural Economics Books series)

Printed by Primerate Kft.

(C) Research Institute of Agricultural Economics

All rights reserved. Reproduction of any parts of this publication as well as storing, transmission or use of data (in written or electronic format) with any kind of database manager is only possible with the prior written permission of the publisher. 


\section{Contents}

Foreword

POTORI, Norbert, DOUCHA, Tomáš, MEDONOS, Tomáš, GÁLIK, Jozef, JAMBOROVÁ, Mária and ČIČOVÁ, Tatiana

Comparison of the agro-food sectors from a macro perspective ............................................ 9

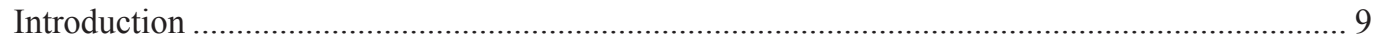

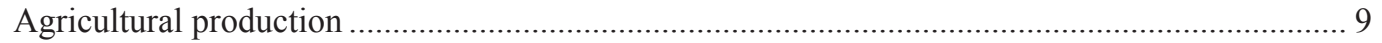

Shares of agriculture and the food industry in the GDP ........................................................ 17

Shares of agriculture and the food industry in employment.................................................... 19

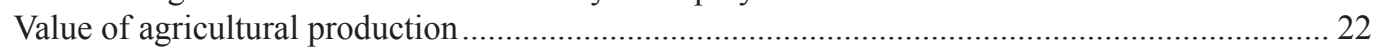

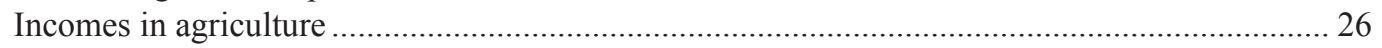

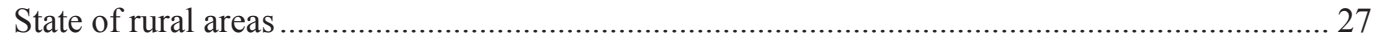

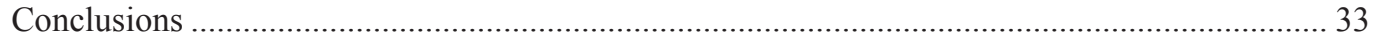

VÁSÁRY, Viktória, BARTOŇ, Petr, BOZIK, Marian and HUMPÁL, Jaroslav

Implementation of the new CAP - a comparative analysis ........................................... 35

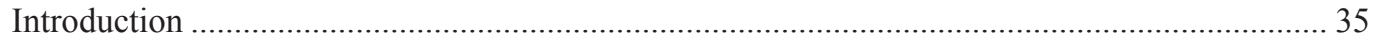

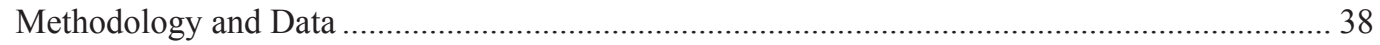

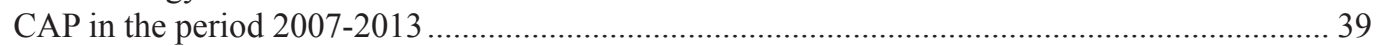

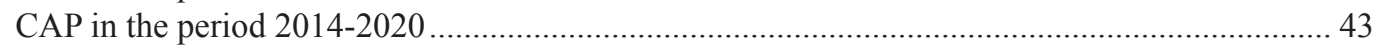

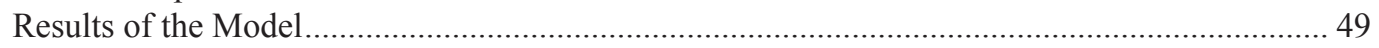

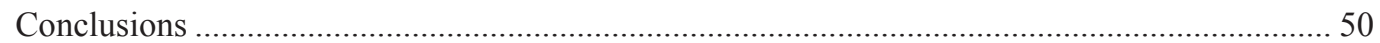

TIKÁSZ, Ildikó Edit, BENE, Enikő, KRÍŽOVÁ, Slávka, NOVOTNÝ, Petr and JAMBOROVÁ, Mária

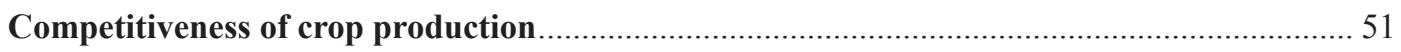

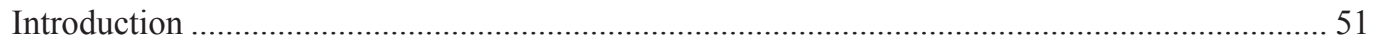

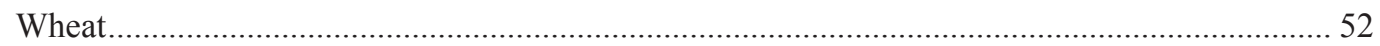

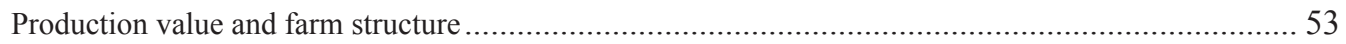

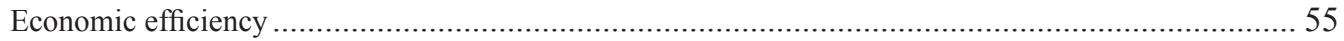

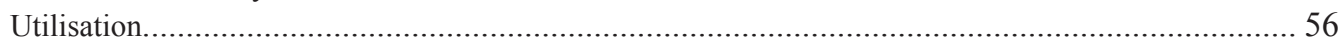

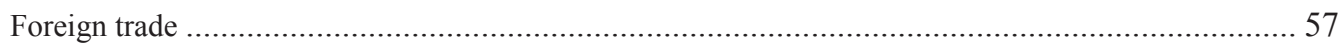

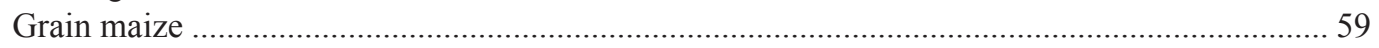

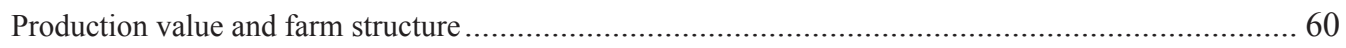

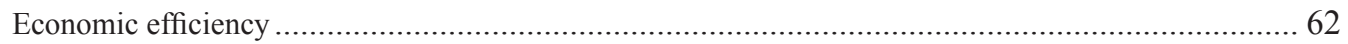

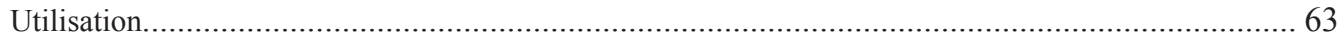

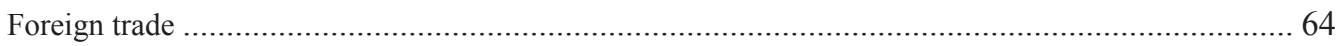

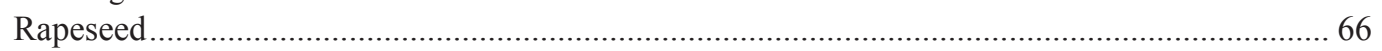

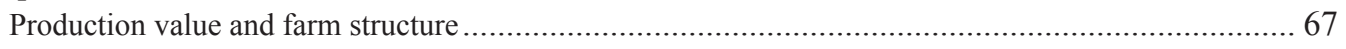

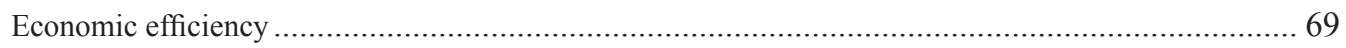

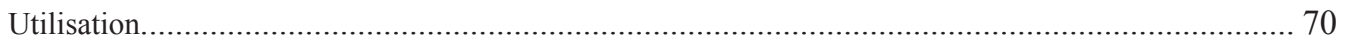

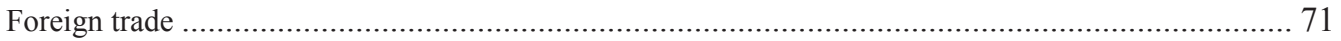

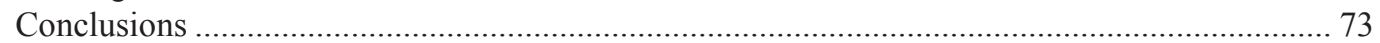




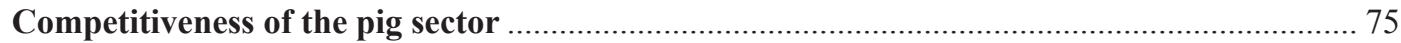

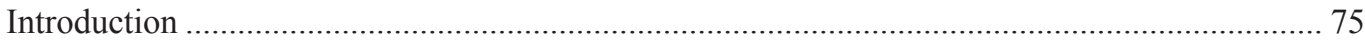

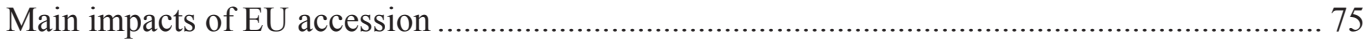

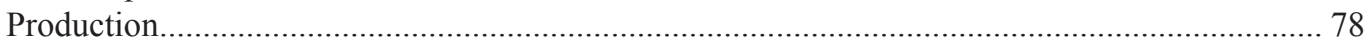

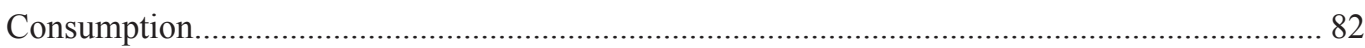

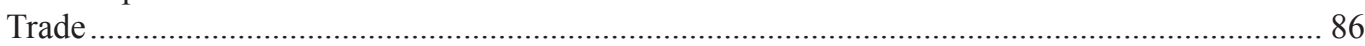

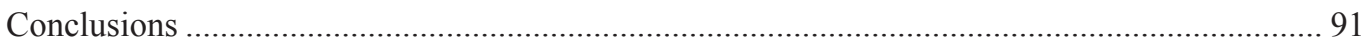

VŐNEKI, Éva, MATOSKOVA, Dagmar, BOSKOVA, Iveta and PÓTI, Gábor

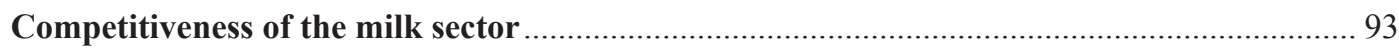

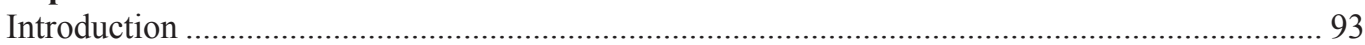

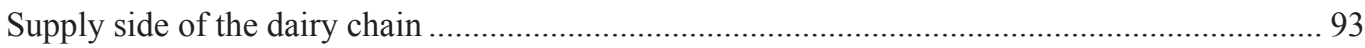

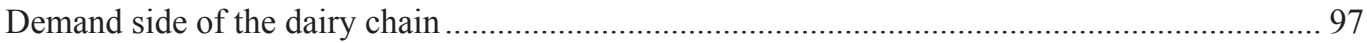

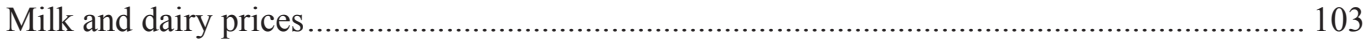

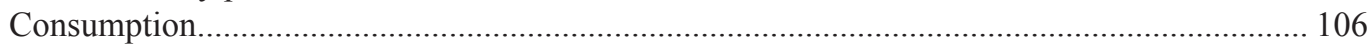

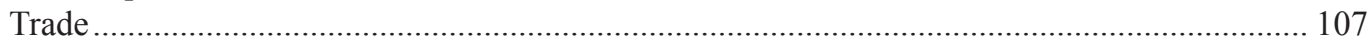

Milk quota system and direct support of milk production ..................................................113

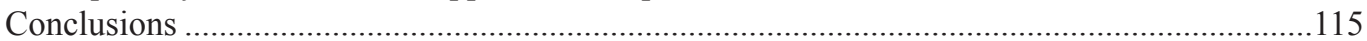

FELKAI, Beáta Olga, SZÉKELYHIDI, Katalin, JANKUNÉ KÜRTHY, Gyöngyi, BELEŠOVÁ, Svetlana, MASÁR, Ivan, MEZERA, Josef and NÁGLOVÁ, Zdeňka

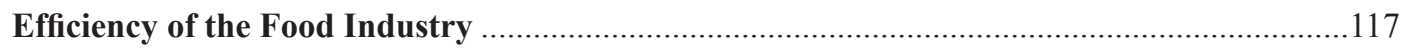

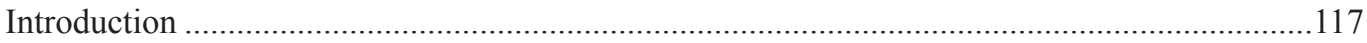

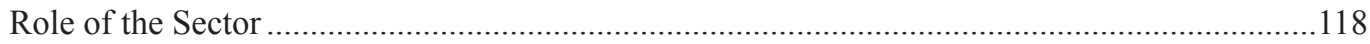

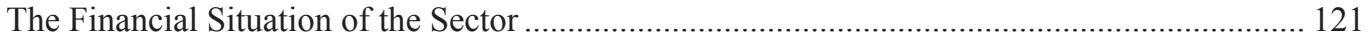

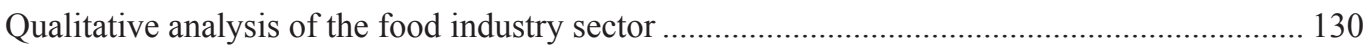

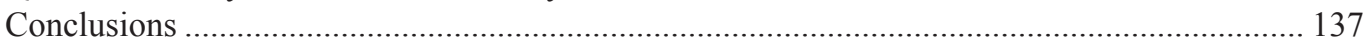

HAMZA, Eszter, BUCHTA, Stanislav and DRLÍK, Jan

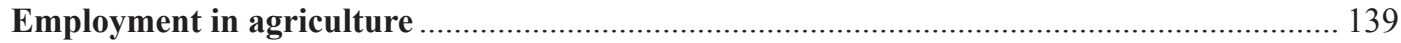

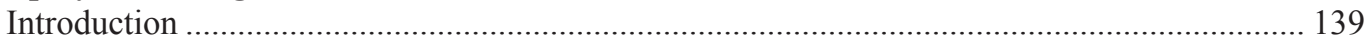

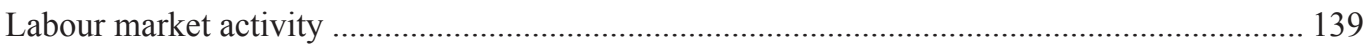

Employment situation in the agricultural sector................................................................... 140

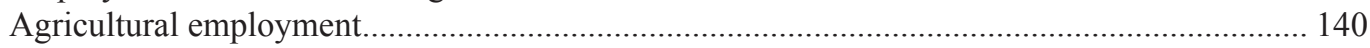

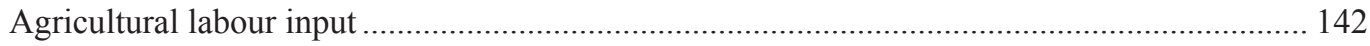

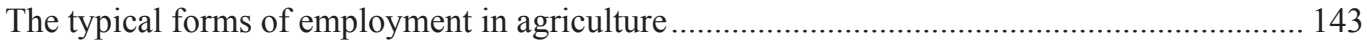

The features of agricultural labour ..................................................................................... 144

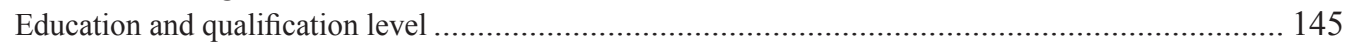

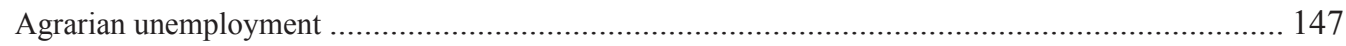

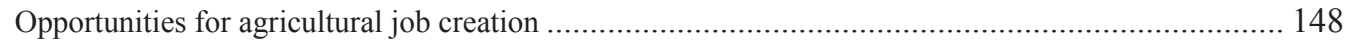

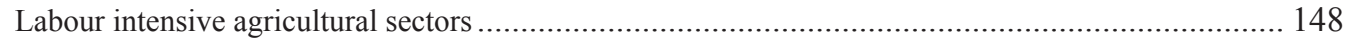

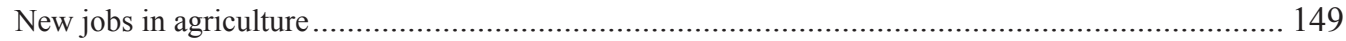

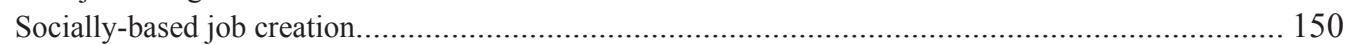

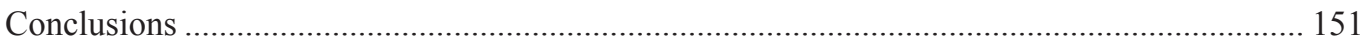


BIRÓ, Szabolcs, TÓTH, Orsolya, RÁCZ, Katalin, ČÁMSKÁ, Klára, VAJCÍKOVÁ, Ružena,

ČIČOVÁ, Tatiana and FEDERIČOVÁ, Zuzana

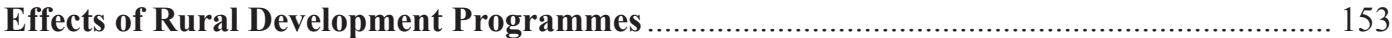

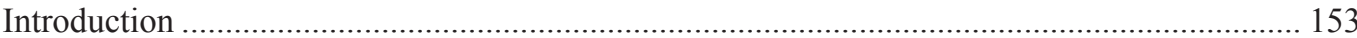

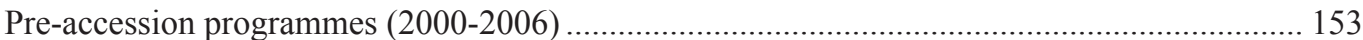

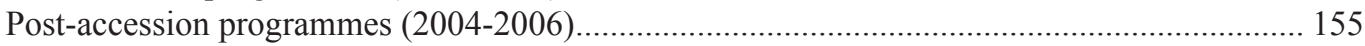

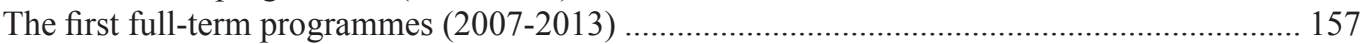

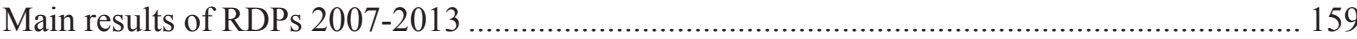

AXIS I: Improving the Competitiveness of the Agricultural and Forestry Sector ............................. 159

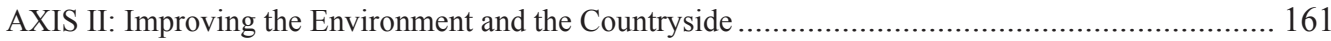

AXIS III: Quality of Life in Rural Areas and Diversification of the Rural Economy ......................... 163

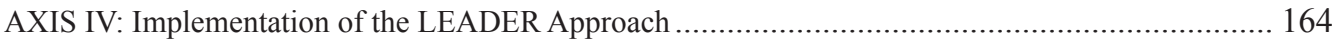

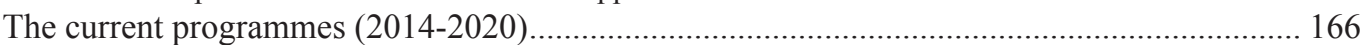

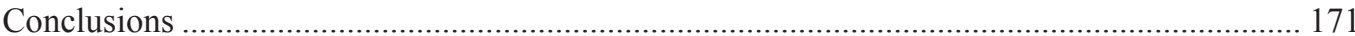

BIRÓ, Szabolcs, BUDAY, Štefan, GRAUSOVÁ, Gabriela, TÓTH, Orsolya, ČıČOVÁ, Tatiana and VILHELM, Václav

Agricultural land ownership, land market and land rent market ................................... 173

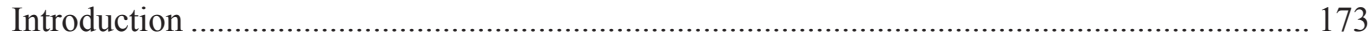

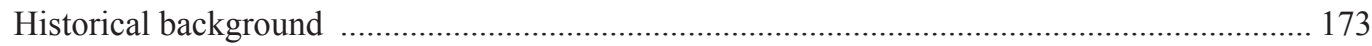

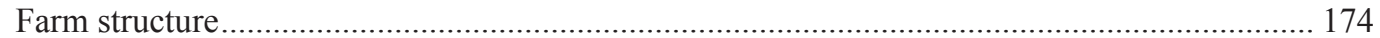

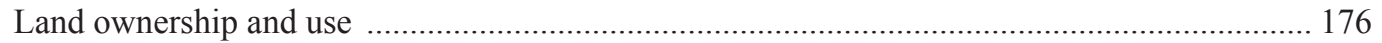

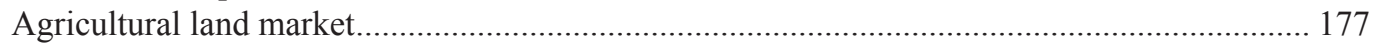

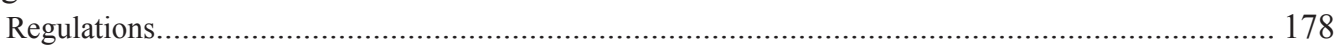

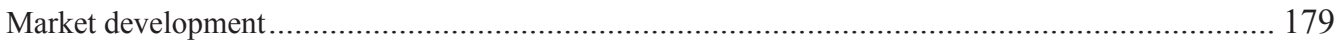

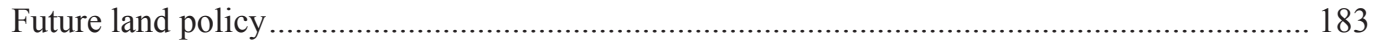

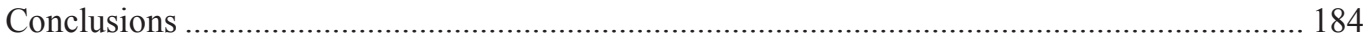

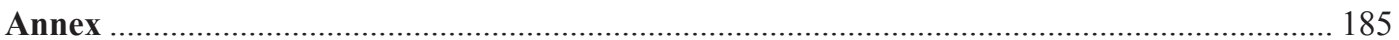

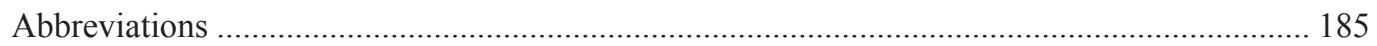

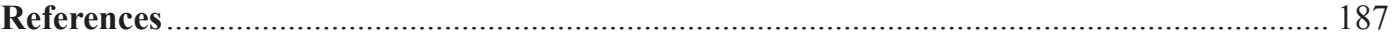

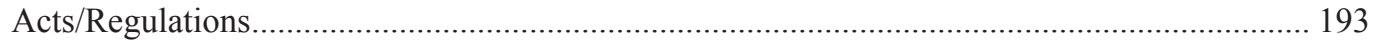





\section{Foreword}

The collaboration that has led to the publication of this book can be traced back to April 2013, when the Research Institute of Agricultural and Food Economics (VÚEPP) in Bratislava, Slovak Republic, approached the Research Institute of Agricultural Economics (AKI) in Budapest, Hungary, with a view to establishing a programme of bilateral cooperation. The approach was very positively received by AKI, and the idea rapidly developed into a plan for a series of trilateral cooperation activities that also included the Institute of Agricultural Economics and Information (IAEI) in Praha, Czech Republic. Representatives of the three institutes met in Budapest at the end of May, 2013 and agreed to work together to enhance mutual research collaboration in the field of agricultural economics, share information and discuss issues related to agricultural economics in the three countries, and establish a coordination group composed by members of the three research institutes.

The cooperation was formalised through the signing, in December 2013, of a trilateral Agreement covering the period 2014-2016 covering the following topics: (a) publication of individual or common papers in the institutes' journals or other journals, and exchange of journals between institutes; (b) exchange of experience via trilateral meetings of specialists; (c) cooperation with other scientific entities and support for affiliation to international networks or construction of a specific network in the institutes' common field of research interest; (d) applications and participation in common international projects; and (e) participation at international meetings with common research/papers and cooperation in organisation of different international meetings. The three institutes agreed that this would be an excellent way to better disseminate, nationally and internationally, the results of their research work and to open new perspectives to future mutual cooperation.

The centrepiece of the programme of cooperation was a trilateral research project entitled "The CAP Impact on the Effectiveness of Use of Agricultural Production Factors and the Economic Efficiency of Agricultural Production and Product Sectors in the Slovak Republic, the Czech Republic and Hungary". The general objective of this project has been: research on rural areas and the agrifood sector by sectoral analysis, country comparisons, identification of positive and negative influences on the rural and agricultural economy, dissemination of research results, and proposals for future policies in the field. Initially intended to cover four topics (implementation of the new Common Agricultural Policy (CAP), agricultural land ownership and related issues, competitiveness and profitability of crop and animal production, and the efficiency of food industry production), further discussion led to eight topics of joint research being agreed.

This book represents the tangible output of the trilateral research project. Each chapter in the book is the product of enthusiastic cooperation between the relevant research specialists of the three institutes, under the overall coordination and guidance of Ing. Tatiana Čičová, PhD of VUEPP, Petr Bartoň of IAEI, and especially Dr. Biró Szabolcs of AKI, who willingly took on the role of Editorin-Chief. Special thanks are also due to Dr. Potori Norbert, Research Director at AKI, for agreeing that AKI would oversee the publication of the volume, and Vrana Attila of AKI's Publications Group, for the excellent formatting. Thanks are also due to Dr. Eleonóra Marišová and Dr. Nábrádi András, who acted as external reviewers. This is the first joint publication between the three institutes and it unquestionably provides instructive and useful knowledge for researchers, stakeholders in the agrofood sector and agricultural policy decision makers. We hope that it will be followed by similar volumes in the coming years.

doc. Ing. Štefan Buday, PhD, Director, Research Institute of Agricultural and Food Economics, Bratislava, Slovak Republic

Juhász Anikó, PhD, General Director, Research Institute of Agricultural Economics, Budapest, Hungary

Ing. Kala Štěpán, PhD, Director, Institute of Agricultural Economics and Information, Praha, Czech Republic 



\title{
Comparison of the agro-food sectors from a macro perspective
}

\author{
POTORI, Norbert' ${ }^{1}$ DOUCHA, Tomáš², MEDONOS, Tomáš², GÁLIK, Jozef ${ }^{3}$, \\ JAMBOROVÁ, Mária ${ }^{3}$ and ČIČOVÁ, Tatiana ${ }^{3}$
}

\section{Introduction}

The aim of this chapter is to compare briefly the development of the Czech, Hungarian and Slovak agro-food sectors from a macro perspective, focusing on, inter alia, the contribution of agriculture and food processing to the national economy, as well as on the development of production structures, financing and agro-food trade. Our analysis was based on data available from the Central Statistical Offices of the three countries. Although the general time frame for the analysis was 2000-2014, references to earlier periods were made where necessary. This chapter provides the context to help to understand better the following chapters. It begins by presenting the changes over time in the agricultural production in the three countries, and then focuses on employment in agriculture and food processing industry. Finally, the value of agricultural production, the incomes derived from the sector and the status and development of rural areas are briefly assessed.

\section{Agricultural production}

The area of Hungary is 93.0 thousand $\mathrm{km}^{2}$, of which the land area is 92.3 thousand $\mathrm{km}^{2}$. In 2014 the utilised agricultural area (UAA) was 5.3 million hectares, while 1.93 million hectares were covered by forests, 65.3 thousand hectares by reeds and 36.6 thousand hectares by fish ponds. The arable area totalled 4.31 million hectares, and fruit orchards, vineyards and kitchen gardens occupied around 92.6, 81.2, and 80.3 thousand hectares of the UAA respectively. The remaining 760.9 thousand hectares were grassland. In 2014, irrigated area accounted for 130.4 thousand hectares, and a 4 per cent increase since 2000 but still representing just 2.4 per cent of the total UAA. Consequently, crop production is heavily exposed to the risk of drought. At approximately 3.7 thousand hectares in 2014 , the area covered by glasshouses and polytunnels was 40 per cent less than in 2000 . The area eligible for EU direct payments in 2014 totalled 4,980 thousand hectares. This represented a decrease of over 100 thousand hectares since 2007, when it peaked at 5,081 thousand hectares, and was around 40 thousand hectares less than in 2004, the first year of application. In the same period, the number of farms eligible for direct payments declined from 208,504 to 177,241.

The vast majority of farmers giving up agricultural activity in the last 15 years farmed less than 10 hectares. In contrast to the number of farms eligible for direct payments, the farm structure survey in 2013 registered 482.5 thousand private holdings, a nearly 50 per cent drop over the census data from $2000^{4}$. There were 8.7 thousand legal entities in 2013, an almost 2 per cent increase since 2000 . The principal arable crops in Hungary have traditionally been maize, wheat, barley, sunflower and oilseed rape (Table 1). The production of each of these would normally exceed domestic needs by about twofold, thus they represent the bulk of exportable agricultural goods. Maize and wheat had relatively stable sowing areas of 1.2 million and 1.1 million hectares respectively in the past, but the area devoted to oilseeds has increased significantly at the expense of other field crops such as barley.

Research Institute of Agricultural Economics, Budapest, Hungary

Institute of Agricultural Economics and Information, Prague, Czech Republic.

National Agricultural and Food Centre - Research Institute of Agricultural and Food Economics, Bratislava, Slovak Republic.

The definition of a farm in Hungary is having a minimum of $1500 \mathrm{~m}^{2}$ land area including agricultural area, forests, reeds and fish ponds; or $500 \mathrm{~m}^{2}$ fruit orchards and/or vineyards; or $100 \mathrm{~m}^{2}$ protected area; or at least one larger livestock such as cattle, pig, sheep, goat, horse etc.; or 50 heads of poultry; or 25 rabbits; or 25 animals kept for fur production; or 25 meat pigeons; or 5 bee families. 
Table 1: All-time production records of the principal arable crops in Hungary.

\begin{tabular}{lcccc}
\hline \multicolumn{1}{c}{ Crop } & Year & $\begin{array}{c}\text { Area } \\
\text { (million hectares) }\end{array}$ & $\begin{array}{c}\text { Yield } \\
\text { (tonne/hectares) }\end{array}$ & $\begin{array}{c}\text { Production } \\
\text { (million tonnes) }\end{array}$ \\
\hline \multirow{2}{*}{ Maize } & 2005 & 1.198 & 7.70 & 9.050 \\
\cline { 2 - 5 } Wheat & 2014 & 1.230 & 7.80 & 9.315 \\
\hline \multirow{2}{*}{ Barley } & 1984 & 1.361 & 5.41 & 7.366 \\
\hline Sunflower & 2014 & 1.112 & 4.73 & 5.261 \\
\hline Oilseed rape & 1992 & 0.480 & 3.59 & 1.723 \\
\hline
\end{tabular}

Source: HCSO

The area under oilseed rape has more than doubled to 240-260 thousand hectares in the years following Hungary's accession to the EU. This parallels the boom in biodiesel production within the EU, an industry heavily dependent on rapeseed oil. Sunflower has also considerably gained in popularity, thanks to the increase in vegetable oil prices, raising the sowing area by around 25 per cent to 580-600 thousand hectares. Owing to the EU sugar policy reform, since 2004 the sugar beet area has fallen by over two-thirds to under 20 thousand hectares. Arable production in Hungary is characterised by considerable seasonal swings in both yields and output. All-time production records for maize, sunflower and rapeseed that were observed after EU accession can be attributed, inter alia, either to the introduction of the EU cereal intervention system, or to the first of the oilseed price rallies in the latter half of the 2000s.

Over 20 per cent of the value of agricultural production in Hungary is accounted for by fruits and vegetables. The fruits sector is dominated by apple production, followed by sour cherries, plums, peaches, apricots and pears. In the vegetables sector, sweet corn, green pepper, tomatoes and water melons are the major products, with sweet corn, either frozen or canned, being an exportable good of outstanding importance. Since EU accession, production both of fruits and vegetables has declined slightly.

Livestock numbers in Hungary have been falling for decades (Table 2 and Figure 1). This process was accelerated firstly by the splitting of large cooperatives during privatisation after the political and economic transition, accompanied by the collapse of the Comecon (Council for Mutual Economic Assistance) market where most of the livestock products were sold, and later by EU accession (i.e. the elimination of trade barriers and the termination of direct support to non-ruminants) as well as the dramatic increases in feed grain and oilseed meal prices.

According to official data, there were 3.1 million pigs by the end of 2014 while, at just around 200 thousand, the number of sows hit an all-time low. It is important to note that the number of pigs almost reached 5 million in 2000. The declines in cattle raising and milk production appear to have been reversed recently. There was a significant increase in the number of cattle in 2014, reaching 802 thousand in December, the highest level until then since EU accession. The number of dairy cows bottomed out in 2010 and also increased, by 16.2 per cent, to 359 thousand in 2014, while milk production gained 5.8 per cent in the same year. Nevertheless, in the 2013/2014 marketing year only around 72.3 per cent of the national milk quota was used. The number of suckler cows (including dual-purpose breeds) reached 359 thousand in 2014, an almost 6 per cent decrease from 2000. 
Table 2: Livestock record numbers in Hungary in the past 50 years versus 1 December 2014.

\begin{tabular}{|c|c|c|c|c|}
\hline Livestock & Year & $\begin{array}{c}\text { Numbers } \\
\text { (thousand) }\end{array}$ & Year & $\begin{array}{c}\text { Numbers } \\
\text { (thousand) }\end{array}$ \\
\hline Cattle & \multirow{2}{*}{1974} & 2,017 & \multirow{2}{*}{2014} & 802 \\
\hline of which dairy cows & & $797^{\text {a) }}$ & & 359 \\
\hline Ewes & 1982 & 1,947 & 2014 & 855 \\
\hline Pigs & \multirow{2}{*}{1983} & 9,844 & \multirow{2}{*}{2014} & 3,136 \\
\hline of which sows & & 740 & & 200 \\
\hline Poultry & \multirow{2}{*}{1982} & 67,552 & \multirow{2}{*}{2014} & 30,521 \\
\hline of which hens & & 42,009 & & 11,946 \\
\hline
\end{tabular}

a) The figure represents all cows (almost entirely of the traditional dual-purpose breed) of which over 90 per cent were used in milk production. Source: HCSO

The number of ewes declined to 855 thousand in 2014. This number was the lowest since EU accession in 2010 (844 thousand), representing just over 65 per cent of the national quota. Broiler chickens and laying hens account for 80-85 per cent of the Hungarian poultry flock. In 2014, the number of broiler chickens was around 30 million (15 per cent less than in 2003), while the number of laying hens fell by 26.6 per cent to 11.946 million during the same period., Turkeys and waterfowl (i.e. geese and ducks) numbered around 2.75 million and 5.3 million in 2014, these figures being 40 per cent less and 1 per cent more respectively than in 2003.

The total area of the Czech Republic is 78.9 thousand $\mathrm{km}^{2}$. In 2014 the total agricultural land area comprised 4.2 million hectares, 53.5 per cent of the country's total area, while forests covered 33.8 per cent. While the latter figure has remained more or less constant over recent years, the former is generally in slight decline. So is arable land, but permanent grassland is slightly increasing (both in single tenths of a per cent). In terms of uses, 70.7 per cent of the agricultural land is arable, 23.7 per cent is permanent grassland and 5.7 per cent is under permanent culture (hop fields, vineyards, gardens and orchards). In terms of capital infrastructure, 25.6 per cent of the agricultural land is drained and 0.4 per cent is irrigated. In total about 1.2 per cent of agricultural land is officially endangered by deficient moisture, while about 5 per cent is endangered by excessive moisture. In terms of alternative uses, 11.7 per cent of agricultural land was farmed in the regime of ecological agriculture, and 1,754 ha ( 0.04 per cent) were planted with Genetically modified (GM) crop (all MON810). The area eligible for EU direct payments covers 3.5 million hectares (84 per cent of agricultural land).

In terms of organisational structure, 69.4 per cent of agricultural land was cultivated by cooperatives and 30.6 per cent by natural person farmers in 2014. Altogether this comprises 48.6 thousand units, although the vast majority of them (44.4 thousand) were natural persons. Of these, 25.3 thousand were registered as sole proprietorships, the remainder being small farmers without a business licence. The average area of agricultural land was 25 ha for natural persons (those registered as sole proprietorships averaging 40 ha of UAA), while the average of businesses was 623 ha. Even among businesses there is a substantial difference between the average sizes of different legal forms. A limited liability company (equivalent to the German $\mathrm{GmbH}$ ) with 345 ha on average was much smaller than the average joint stock company (equivalent to the German AG) with 1,293 ha. Interestingly, the average area farmed by cooperatives is very similar to that of the joint-stocks with 1,344 ha. Overall, the Czech agricultural sector is relatively more dominated by businesses than in many other European countries. This applies especially to arable farming, where businesses manage three quarters of total arable land. The split of agricultural land into individual business forms is one quarter limited liability companies, one quarter joint stocks and one fifth cooperatives. The relative dominance of businesses in animal production is even greater as they raise 76 per cent of cattle (within which almost 90 per cent of dairy cows), 92 per cent of pigs and 91 per cent of poultry. 
Figure 1: Changes in livestock numbers expressed in percentages of 1990 in Hungary, 2000-2014.

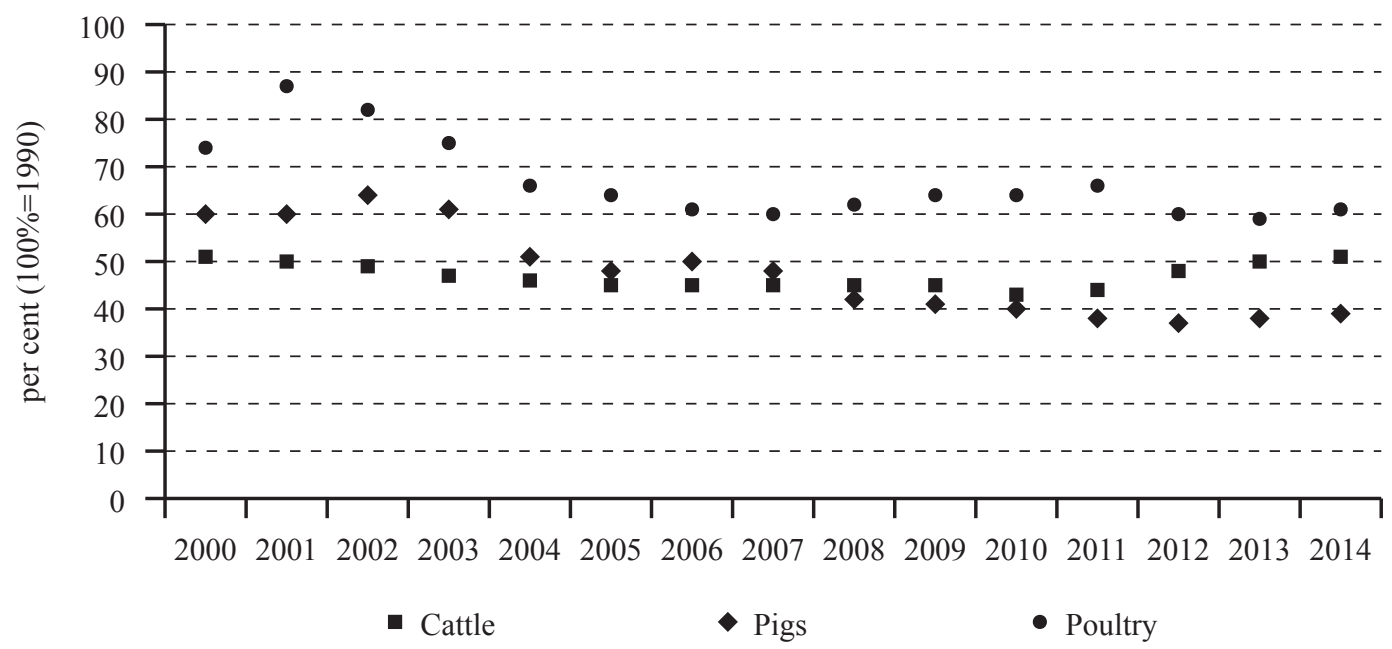

Source: HCSO

The principal arable crops in the Czech Republic since 2000 have been wheat, barley, potatoes, sugar beet, oilseed rape and maize (Table 3). Wheat has occupied the largest area of arable land, with over 800 thousand hectares sown every year since the 1970s. The area of barley is currently around 350 thousand ha, although in the intervening period it has been double that, peaking at 736 thousand ha in 1979 and holding above 500 thousand ha as late as 2006.

Table 3: All-time production records of the principal arable crops in the Czech Republic.

\begin{tabular}{lcccc}
\hline \multicolumn{1}{c}{ Crop } & Year & $\begin{array}{c}\text { Area } \\
\text { (thousand hectares) }\end{array}$ & $\begin{array}{c}\text { Yield } \\
\text { (tonne/hectares) }\end{array}$ & $\begin{array}{c}\text { Production } \\
\text { (million tonnes) }\end{array}$ \\
\hline Wheat & 2014 & 835.9 & 6.51 & 5.442 \\
\hline Barley & 2014 & 350.5 & 5.61 & 3.157 \\
\hline $\begin{array}{l}\text { Fodder } \\
\quad \text { potatoes }\end{array}$ & 1937 & & & \\
$\quad$ sugar beet & 1925 & 0.507 & 18.40 & 9.331 \\
Oilseed rape & 2014 & 0.239 & 31.17 & 7.451 \\
\hline Maize & 2012 & 389.2 & 3.95 & 1.537 \\
\hline
\end{tabular}

Source: CZSO

The traditional Czech staple food - the potato - has been in steady decline in area from the peak of 500 thousand ha yielding almost 10 million tonnes on the eve of World War Two down to about 24 thousand ha yielding some 600 thousand tonnes. Another traditional crop that feeds the formerly very developed sugar refinery industry (and distilleries) is the sugar beet. It also suffered some decline, but by no means as dramatic as the potato. During most years since the change of regime, over 150 thousand ha were planted and yielded more than 5 million tonnes. This then fell to an all-time low of some 59 thousand ha and 2.7 million tonnes in 1999, but since then the numbers have recovered somewhat, thanks also to the subsidies that the crop has been receiving. In all but two years of this century it has held well above 3 million and has been close to the 4 million tonnes level in most recent years. 
The story for oilseed rape is very much similar to neighbouring countries. It occupied around 30 thousand ha until the 1970s but, owing to technological advances combined with subsidies, the area increased rapidly and reached 100 thousand ha before the end of socialism. By the end of the century the 300 thousand ha mark had been broken, and although there have been variations since then, in most recent years it even broke the 400 thousand ha level. More than one million tonnes are harvested annually. Arable production in the Czech Republic is heavily exposed to weather conditions which influence the improvement of yields and output. All-time production records for maize, sunflower and rapeseed were observed after EU accession.

Fruits and vegetables account for just over 5 per cent of the value of agricultural production in the Czech Republic. The fruits sector is dominated by apple production with plums, cherries, pears and apricots behind by some distance. The vegetable sector is dominated (in terms of area) by onions (about 16 per cent of the vegetable area), followed by sweet peas (11 per cent) and cabbage (10 per cent). The main exports included, next to onions, carrots, watermelons and tomatoes. Perhaps as an indicator of continued strong links with the former member of a federal state, 75 per cent of vegetable exports went to Slovakia. There has been no significant decline in fruit and vegetable production since EU accession.

Livestock numbers in the Czech Republic have been falling since the end of communism (Table 4 and Figure 2) for similar reasons as in Hungary. While the number of cattle hovered between 3 and 3.5 million throughout the interwar period as well as during the communist regime, it has since declined to 1.35 million (most of the decline happening in the first several years after the collapse of socialism).

Table 4: Livestock record numbers in Czech Republic in the past 50 years versus 1 April 2014.

\begin{tabular}{|c|c|c|c|c|}
\hline Livestock & Year & $\begin{array}{l}\text { Numbers } \\
\text { (thousand) }\end{array}$ & Year & $\begin{array}{c}\text { Numbers } \\
\text { (thousand) }\end{array}$ \\
\hline Cattle & \multirow{2}{*}{1982} & 3,556 & \multirow{2}{*}{2014} & 1,374 \\
\hline of which dairy cows & & $1,317^{\mathrm{a})}$ & & 371 \\
\hline Ewes & 1990 & 429 & 2014 & 225 \\
\hline Pigs & \multirow{2}{*}{1981} & 5,105 & \multirow{2}{*}{2014} & 1,617 \\
\hline of which sows & & 368 & & 103 \\
\hline Poultry & \multirow{2}{*}{1984} & 34,192 & \multirow{2}{*}{2014} & 21,464 \\
\hline of which hens & & 16,556 & & 6,756 \\
\hline
\end{tabular}

a) The figure represents all cows.

Source: CZSO

The number of pigs gradually increased from just under 2 million to just over 5 million in 1981, the all-time peak, but has since dwindled to the current 1.6 million. Unlike beef, however, most of the decline in pig numbers has been more or less gradual over the period, not having been halted since the turn of the century by generous subsidies as with beef. Czechs are, however, eating no less pork - after all, it is the main ingredient in the nation's diet. But the domestic sector has lost out mostly to foreign competition; the inability to raise sufficient offspring from sows has been one of the main problems. Poultry numbers have varied much less over the decades. In the 1970s they broke the 20 million threshold and in the 1980s the 30 million threshold, hovering around that figure ever since. Since the turn of the century, however, there has been a steady decline from the high 20 s to the current low 20s. 
Figure 2: Changes in livestock numbers expressed in percentages of 1990 in the Czech Republic, 2000-2014.

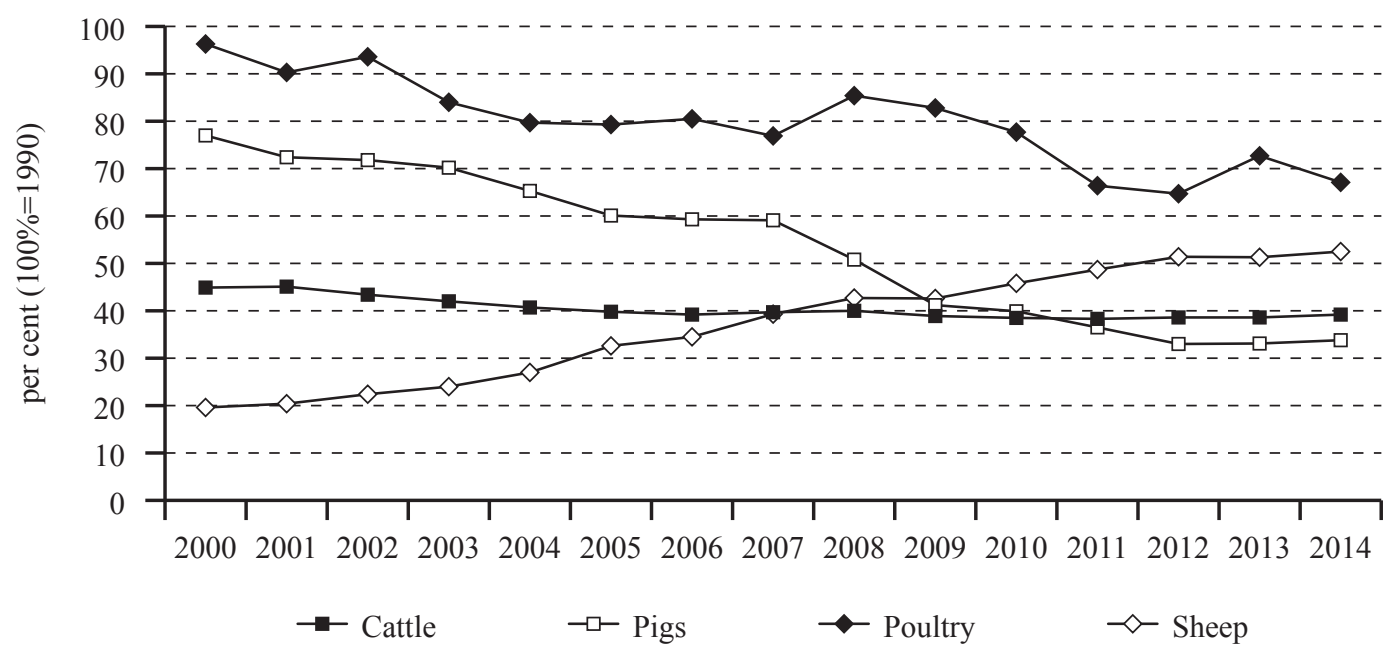

Source: CZSO

Sheep numbers have, by contrast, witnessed a roller-coaster. They declined from over 400 thousand in the mid-1950s to 120 thousand in the mid-1960s. Then they rose again to 430 thousand at the end of the regime change, only to dwindle to just 84 thousand by the turn of the century. In line with consumer demand for alternative sources of meat and dairy, ecological farming and (some) subsidies, the numbers have grown steadily since then and now stand at a relatively healthy 225 thousand.

The total area of Slovakia is 4.9 million hectares; of this UAA constituted 1.9 million hectares in 2014, and forest land 2.0 million hectares. Arable land comprises 70 per cent, and permanent meadows and pastures 27 per cent of the area, and the balance is permanent crops. The area of registered land in ecological farming was 162 thousand hectares in 2013, i.e. 8 per cent of the UAA. During last decade the ecological areas have tripled in size. Since 2007 a declining interest of agricultural businesses in renting irrigation facilities has been evident as the area decreased by 58 thousand hectares to less than 97 thousand hectares. However, from this rented area just 24 thousand hectares are really irrigated.

One decade ago the share of animal production in total gross agricultural output was higher than crop production (around 53 per cent) but in the last couple of years crop production has prevailed (58 per cent). The primary crops are cereals (wheat, barley and maize), oilseeds (rapeseed, sunflower) sugar beet and potatoes. The major animal commodities are sheep and poultry. Slovakia is selfsufficient in cereals, oilseeds, sheep meat and sheep milk, cow milk and beef cattle.

The harvested area of cereals covered 770 thousand hectares on average during the period 20032013, of which wheat constituted 47 per cent, barley 24 per cent and grain maize 22 per cent. The average weight of cereal production was 3.2 million tonnes but production fluctuated between years, mainly due to the weather conditions over the growing season. During the past decade, Slovak growers harvested the highest production (4.1 million tonnes) in 2008 and lowest in 2003 (2.5 million tonnes). Since 2003, crop production has been affected by many factors such as rising input costs, worsening economic conditions, decline in livestock herds, strengthened competition of foreign growers, sale prices volatility, CAP regulations, the bio-fuels market and climate change. Over the past ten years the harvested area of wheat has ranged from 340 to 390 thousand hectares, with an average yield of 3.3-4.6 tonnes per hectare and production of 1.2-1.8 million tonnes. The total supply 
of maize for grain has been increasing and self-sufficiency reached 125.9 per cent on average during the monitored period. The maize harvested area ranged from 144 to 221 thousand hectares. The volume of maize production and per hectare yield varied from 601 to 1,444 thousand tonnes and 3.977.15 tonnes per hectare respectively. The harvested area of maize in 2013 was 56.0 per cent higher than in 2003 due to more favourable climate conditions and growing bio-ethanol production based on maize. While in 2003 the maize crop was 601 thousand tonnes, ten years later production exceeded 1,400 thousand tonnes, i.e. it increased by 86.8 per cent. In the period 2003-2013 the harvested area of barley ranged between 121 and 270 thousand hectares. The harvested area of barley decreased in 2013 by 58.7 per cent compared to the level in 2003 . This was caused by a gradual reduction in the spring barley area and changes at malt and beer producers. During the period 2003-2013 the average barley crop reached 648 thousand tonnes per year. Oilseed rape occupied the most important position among oilseeds, on average 54 per cent of the total oilseeds planting area and around 17 per cent of the crop production area. Owing to high farm gate prices and rising demand for bio-diesel production, oilseed rape became the crop recording the highest growth rate of planting area.

Potato cultivation showed a gradual declining trend during past decade. The crop is mainly affected by price instability on the domestic market, hectare yields fluctuation, increased imports and the situation in neighbouring countries. The harvested area of potatoes decreased by 65.1 per cent in 2013 compared to 2003. During the period 2003-2013 the average potato production was 251 thousand tonnes while the smallest crop was recorded in 2010, less than 126 thousand tonnes, and biggest in 2003, which exceeded 392 thousand tonnes.

The development of cropping areas in Slovakia was mainly influenced by the restructuring of agricultural production after 1989 and changes in market conditions since EU accession. In the period 1970-2014, the most important crops grown in Slovakia were cereals including wheat, barley and grain maize, followed by rapeseed, sunflower, potatoes and sugar beet (Table 3 ). The largest harvested area of all cereals was represented by wheat with about 400 thousand hectares. The largest area of wheat was recorded in 2001 (448.9 thousand ha) and the lowest in 1999 (295.8 thousand ha). In Slovakia, barley is mainly used for malting. The barley harvested area reached an average of 231.7 thousand ha during this time. From 1970 to 2014 a significant drop in planting areas was recorded for oats, grain legumes, potatoes and sugar beet. The most significant progress was observed for oilseed rape of which the harvested area increased from 10.9 thousand ha in 1970 to 164.0 thousand ha in 2010, when it reached a maximum for the whole period. The main reasons why producers grow oilseed rape are the favourable marketing conditions relating to the demand in terms of increasing consumption for food production as well as non-food production and the production of biodiesel. In recent years, the areas of grain maize have increased in Slovakia. Despite climate change, it provides sufficient yield for the domestic agri-food market. While in 1970 grain maize was grown on 113.0 thousand ha, in 2013 a maximum of 221.5 thousand ha of harvest area was reached. An increasing maize growing area was also affected by the possibility to sell the grain for bioethanol production. In recent years, an unfavourable situation has developed with potato production: the harvested area declined from 108.1 thousand ha in 1970 to 9.1 thousand ha in 2014. This was caused by the economic conditions of producers, weather fluctuations, falling consumption of potatoes by Slovaks and competition with neighbouring countries. 
Table 5: All-time production records of the principal arable crops in Slovakia.

\begin{tabular}{lcccc}
\hline \multicolumn{1}{c}{ Crop } & Year & $\begin{array}{c}\text { Area } \\
\text { (thousand hectares) }\end{array}$ & $\begin{array}{c}\text { Yield } \\
\text { (tonne/hectares) }\end{array}$ & $\begin{array}{c}\text { Production } \\
\text { (million tonnes) }\end{array}$ \\
\hline Maize & 2014 & 216.2 & 8.39 & 1.814 \\
\hline \multirow{2}{*}{ Barley } & 2014 & 379.3 & 5.46 & 2.072 \\
\hline Sunflower & 1974 & 274.4 & 4.05 & 1.110 \\
\hline Oilseed rape & 2003 & 131.0 & 1.93 & 0.253 \\
\hline Potatoes & 2014 & 125.6 & 3.57 & 0.449 \\
\hline Sugar beet & 1971 & 108.3 & 13.73 & 1.487 \\
\hline
\end{tabular}

Source: Statistical Office of the Slovak Republic (SO SR)

Livestock numbers in Slovakia have been falling for decades (Table 6 and Figure 3) for similar reasons as in Hungary and the Czech Republic. While the number of cattle hovered between 1.3 and 1.5 million throughout the 1970s and 1980s, it has declined to 464 thousand since (most of the decline in cattle numbers has been more or less gradual over the period).

Table 6: Livestock record numbers in Slovakia in the past 50 years versus 1 April, 2014.

\begin{tabular}{|c|c|c|c|c|}
\hline Livestock & Year & $\begin{array}{l}\text { Numbers } \\
\text { (thousand) }\end{array}$ & Year & $\begin{array}{l}\text { Numbers } \\
\text { (thousand) }\end{array}$ \\
\hline Cattle & \multirow{2}{*}{1984} & $1,647.4$ & \multirow{2}{*}{2014} & 463.5 \\
\hline of which dairy cows & & $594.1^{\text {a) }}$ & & 143.1 \\
\hline Ewes & 1970 & 698.3 & 2014 & 377.4 \\
\hline Pigs & \multirow{2}{*}{1979} & $2,791.3$ & \multirow{2}{*}{2014} & 629.5 \\
\hline of which sows & & 200.5 & & 40.2 \\
\hline Poultry & \multirow{2}{*}{1982} & $17,128.7$ & \multirow{2}{*}{2014} & $11,340.2$ \\
\hline of which hens & & $7,824.3$ & & $5,931.3$ \\
\hline
\end{tabular}

a) The figure represents all cows.

Source: SO SR

The number of dairy cows decreased by 29.1 from 2004 to 143 thousand in 2014. Nevertheless, only around 78.0 per cent of the national milk quota was used in the 2013/2014 marketing year. The number of suckler cows (including dual-purpose breeds) reached 56.4 thousand in 2014 which is an 87 per cent increase compared to 2004 . The number of pigs peaked at 2.8 million in 1979 , but has since dwindled to the current 640 thousand (most of the decline happening in the first several years after the EU accession). Poultry numbers have varied much less over the decades. In 1976 they broke the 15 million threshold and in 1982 the 17 million threshold. Up to the turn of the century, however, there has been a steady decline. Since EU accession poultry numbers have fluctuated around 12 million. Sheep numbers declined from almost 700 thousand at the end of the 1960 s to 540 thousand in the mid 1970s. Then they rose again to 698 thousand in the mid 1980s, only to dwindle to just 316 thousand by the turn of the century. The numbers have grown steadily since then and currently stand at a relatively healthy 377 thousand. 
Figure 3: Changes in livestock numbers in Slovakia, 2000-2014.

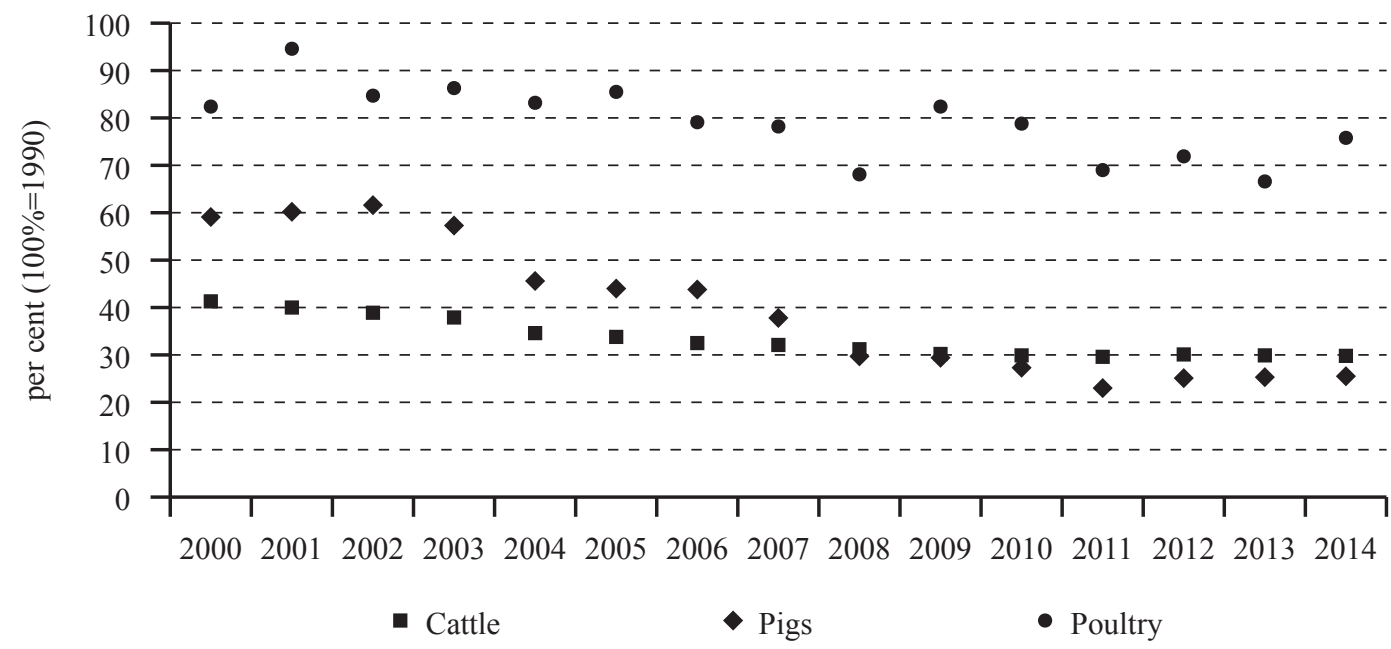

Source: SO SR

\section{Shares of agriculture and the food industry in the GDP}

Hungary has permanently been exposed to the shifts in the confidence of its lenders in the new Millennium due to its high foreign currency indebtedness. As one of the most vulnerable among the Central and Eastern European economies, it was already hit hard by the global financial and economic crisis in 2008, experiencing a decline in exports as well as in domestic consumption, and fixed asset accumulation, dampened by government austerity measures in subsequent years which resulted in the contraction of the economy. Although Hungarian agriculture and the processing industries had been in a long recession before EU accession, due to the general macroeconomic, legal and social environment, the crisis impacted the agro-food sector to a lesser extent than other sectors of the national economy (Potori et al., 2011).

In 2014, agriculture in Hungary contributed 3.7 per cent to the Gross Domestic Product (GDP), remarkably the same as in 2003, and almost 1.5 times higher than the EU-27 average. The unprecedented high volatility of agricultural produce prices and weather extremes in recent years have interrupted the declining trend and made the year on year changes of this indicator rather erratic (Figure 4). In 2009, for instance, arable production was affected by the most severe drought in decades while in 2011 high commodity prices coincided with favourable weather conditions and the downturn of other sectors of the national economy which ultimately led to recession in 2012.

The Czech Republic enjoyed a reasonable boom at the beginning of the century, similar to many advanced industrialised countries. Unlike in many of those, however, sovereign debt was growing since budget deficits were run even during the boom years. The financial crisis hit hard, but only indirectly, through a loss of many export markets; the domestic financial industry has been sound. There are no major domestic banks and Czech branches of international retail banks are always among the healthiest in the respective groups. After the 2008 financial turmoil, the Czech Republic experienced a decline in exports as well as in domestic consumption, and fixed asset accumulation. Given that the previous boom was dominated by the expansion of industry (especially in the exportoriented automotive sector), it is clear that the relative impact of the global economic downturn was smaller in agriculture. Not surprisingly, therefore, the share of agriculture in the GDP actually rose in 2008, halting a secular downward trend since the beginning of the century (and beyond). Agriculture in the Czech Republic (including fisheries and forestry) contributed 3.93 per cent to the GDP at 
the start of the century, but only 1.68 per cent a decade later! A combination of reasonable harvests and factor prices in the most recent years has meant that the share has recovered somewhat. Several floods affected agriculture severely, especially in 2002, 2009 and 2013. In recent years, the share of agriculture in the GDP seems to have remained constant.

The share of Slovak agriculture in the economy measured by GDP was 4.0 per cent in 2014, 0.5 percentage points lower than in 2002. The share of agriculture in the GDP was the lowest in 2010 ( 2.6 per cent) and the highest in 2001 and 2002 (4.5 per cent). The share of agriculture in the GDP has been continuously increasing since 2010 .

Figure 4: Share of agriculture (including forestry, hunting and fisheries) in the GDP in Hungary, the Czech Republic and Slovakia, 2000-2014.

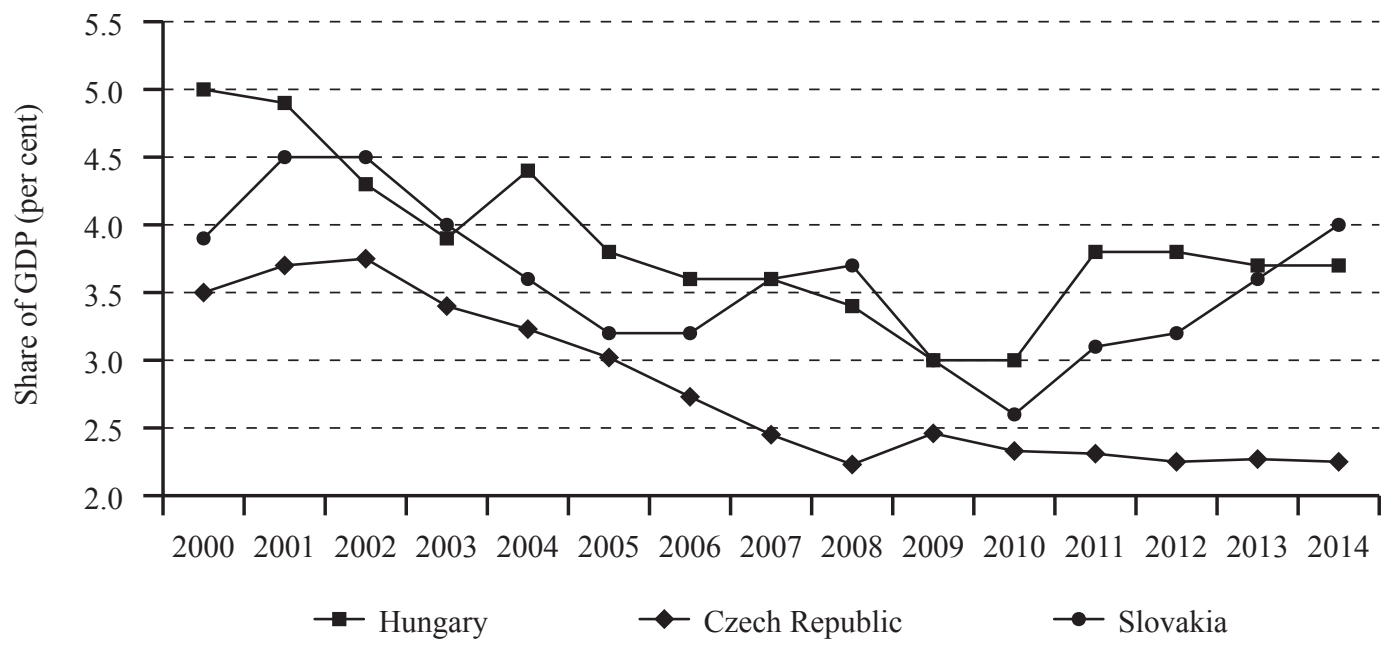

Source: HCSO, CZSO and SO SR

In Hungary share of the GDP of the food processing industry has been falling continuously (Figure 5). A relatively large rise in 2011 can be attributed mainly to the extreme price movements and to the slowdown of the whole economy, while in 2008 and 2009 the economic crises contributed to the relative strengthening of the position of the food processing industry. In recent years the position of the food processing industry seems to have been stronger in terms of its contribution to the GDP. Food price inflation has been racing ahead of the Consumer Price Index in Hungary since 2006. Depreciation in the value of the Hungarian Forint (HUF) against the Euro (EUR) has also impacted on the performance of the agro-food sector.

In the Czech Republic, compared to agriculture, the food industry's contribution to the national economy is more stable from year to year. Through the mid-2000s it managed to stay around or above 3 per cent, but especially since the crisis seems to be resting around 2.5 per cent (Figure 5). The decline is due to a combination of factors, but consumers continue to be very price conscious. In spite of government's and NGOs' campaigns that quality (at a price) is also important, data suggest that price is king, even if it means importing food. Some see large supermarkets as the main culprit exerting pressure on prices; it is undisputed that the Czech Republic has one of the highest shop floor ratios to population in the EU, reflected in a relatively strict competition in the retail sector. Since 2012, the share of the food processing industry in the GDP is mostly constant. One recent development which is likely to affect both sectors (but which may not have been fully felt yet) is the sudden artificial devaluation (by about 10 per cent) of the Czech currency through the Central Bank's intervention since autumn 2013. The price of any foreign-made inputs in both sectors immediately 
increased, although effectively it meant an increase in Czech money available through EU subsidies (which are denominated in EUR).

Figure 5: Share of the food processing industry in the GDP in Hungary, the Czech Republic and Slovakia, 2000-2014.

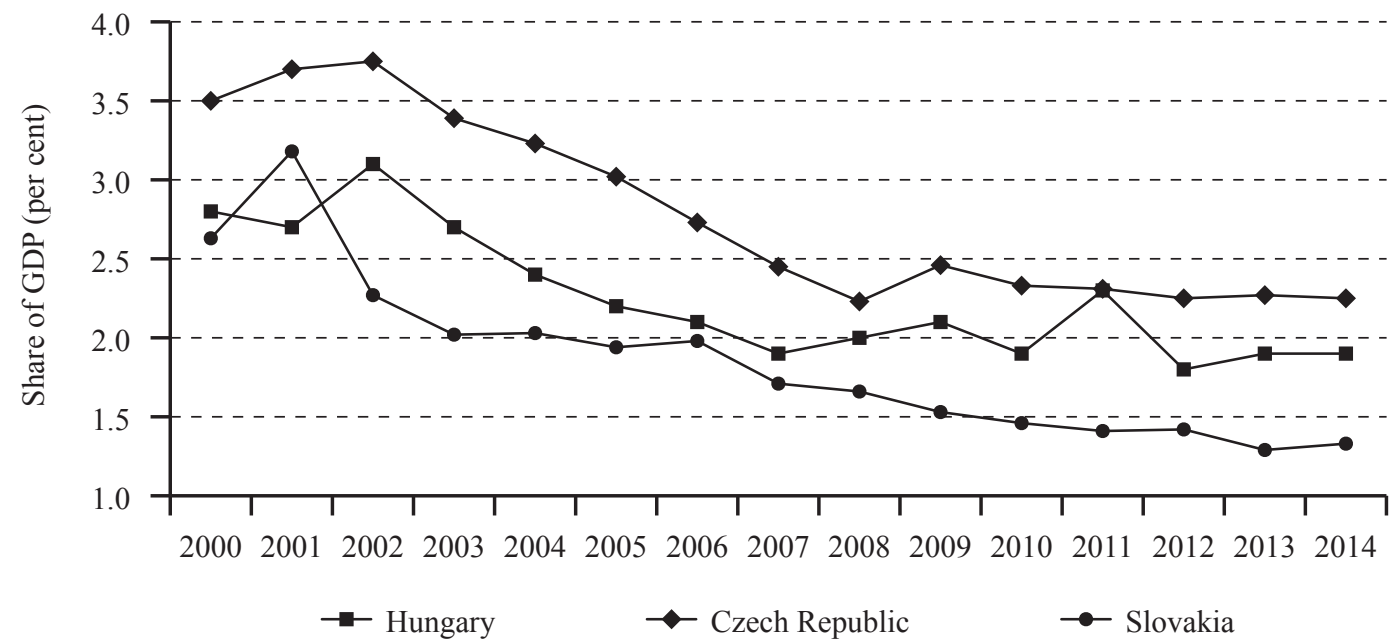

Source: HCSO, CZSO and SO SR

In Slovakia the share of the food processing industry in the GDP shows a continuously declining trend. It was the highest in 2001 (3.2 per cent) and the lowest in 2013 and 2014 (1.3 per cent). Since 2004 the growth of intermediate consumption in Slovak agriculture was faster than total agricultural output. Similarly, the fixed capital consumption had faster dynamics compared to gross value added formation. The diminution of production capacities, and the decrease of agricultural output and employment rate persist.

\section{Shares of agriculture and the food industry in employment}

The share of agriculture in employment had been declining continuously in Hungary for many years. However, in 2009 this trend was reversed (Figure 6) by the economic crisis which severely impacted on other sectors of the national economy, and by the simplification of a bureaucratic seasonal work permit process. In 2011 the share of agriculture in employment increased by an even larger proportion than in the previous years, reaching the level of 2006. This can be attributed to a modification in the public work system: since 2011, public workers have recorded as regular employees. The share of agricultural employment in Hungary has followed a slightly declining trend since 2012. The number of agricultural workers can be determined in several ways, while labour input can be calculated based on some more credible, international methodologies. Although annual work unit (AWU) can be used to examine the structure of agricultural work, it is not suitable for comparison with other branches of the national economy since it expresses the amount of work and not the number of workers. The share of the food processing industry in employment also decreased until 2008. The economic downturn can again explained the break in this trend in 2009 as it resulted in the loss of jobs in other sectors of the national economy. Since 2012, the share of the food processing industry in employment has shown a slight increasing trend. 
Figure 6: Share of agriculture (including forestry, hunting and fisheries) and food processing industry in employment in Hungary, 2000-2014

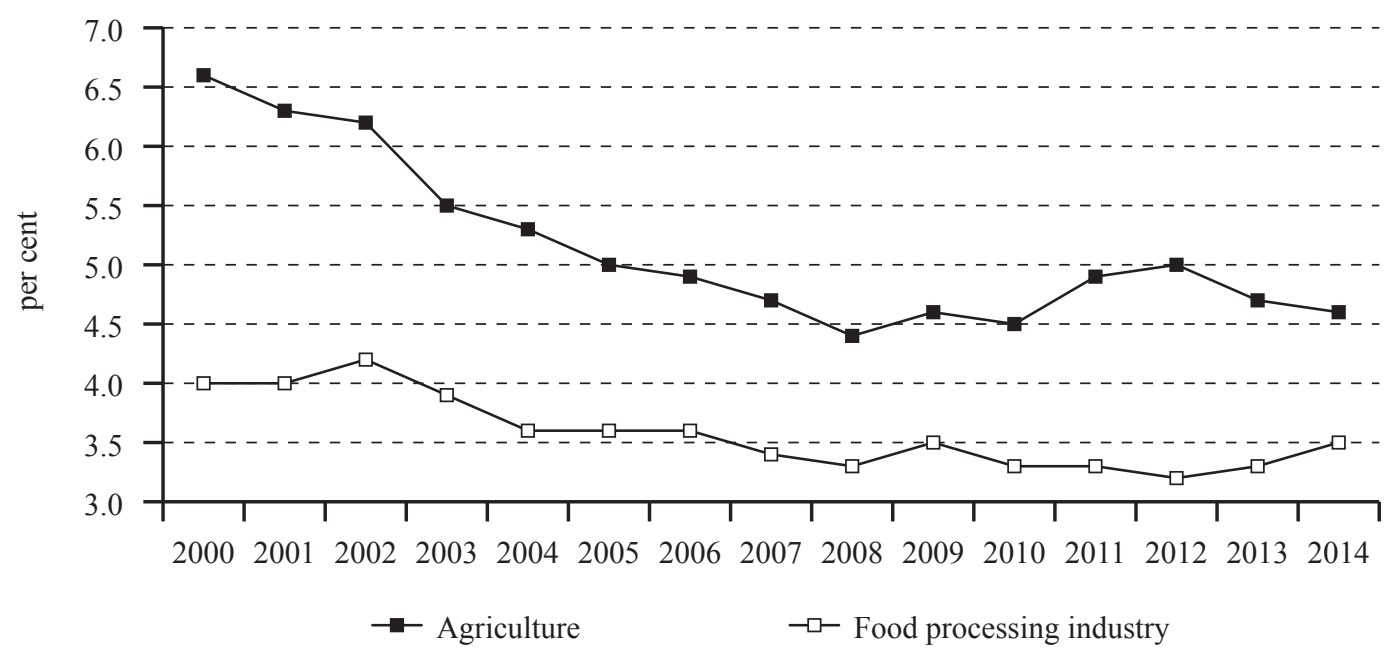

Source: HCSO

The share of agriculture in employment in the Czech Republic has been declining since 2000, but it has been at around the same level (2.63-2.64) since 2010. That the share in employment is higher than the share in the GDP is a testament to the lower-than-average productivity in the sector compared to the rest of the national economy. However, Figure 7 reveals another interesting trend. The small increase in the GDP share in the last four years or so is not reflected by a rise in the employment share. This clearly indicates that the rise in agriculture's prominence has been due to intensive rather than extensive factors, especially favourable market conditions which allowed the relative prominence to grow without employing more people. Given that Czech industrial and service sectors were hit harder by the European recession, a slight rise in agriculture's share in employment could have even been predicted.

The share of the food processing industry in employment also decreased throughout the period, although once again less so than in agriculture. In fact, there was a small trend reversal just before the onset of the economic downturn post-2008. The sector has been experiencing some significant mergers of large companies which contributed to streamlining the labour force numbers. It is also affected by some bottlenecks: Czech abattoirs, for example, do not seem to be as efficient and productive as foreign ones, so some live animals are exported and a relative large quantity of meat is then re-imported for the domestic processing.

In 2010, 91.0 thousand people were working on Slovak farms, a 53 per cent drop from 2000. This was among the lowest values reported within the EU-28. In terms of AWU, the decrease is very similar: from 117.8 thousand AWU to 54.2 thousand AWU. In terms of sole holders, the share of females moved from 14 per cent in 2000 to 16 per cent in 2010 (Eurostat, 2014). Since 2000, the share of agriculture and the food processing industry in employment has been continuously declining. The highest share of agriculture in employment was in 2000 (6.22 per cent) and the lowest was in 2012 (3.19 per cent). The highest share of the food processing industry in employment was in 2000 (3.26 per cent) and it was the lowest in 2014 (1.89 per cent) (Figure 8). 
Figure 7: Share of agriculture (including forestry, hunting and fisheries) and food processing industry in employment in the Czech Republic, 2000-2014.

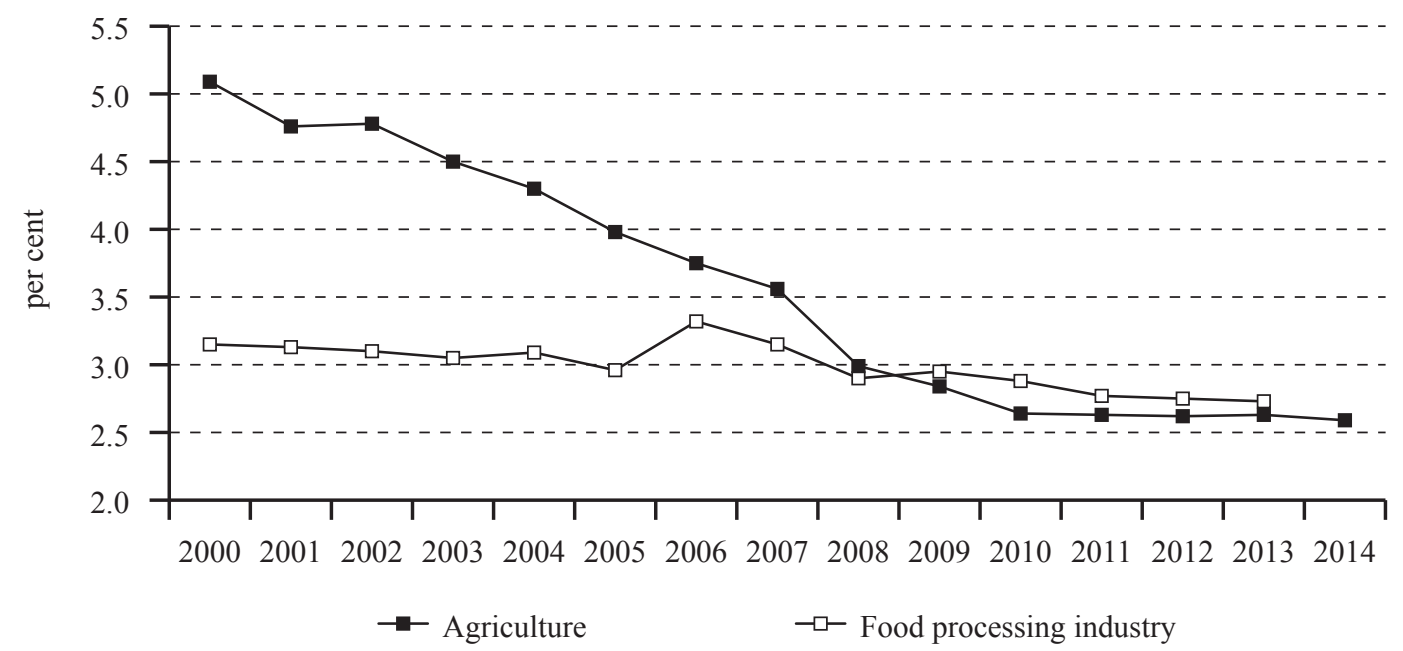

Source: CZSO

Figure 8: Share of agriculture (including forestry, hunting and fisheries) and food processing industry in employment in Slovakia, 2000-2014.

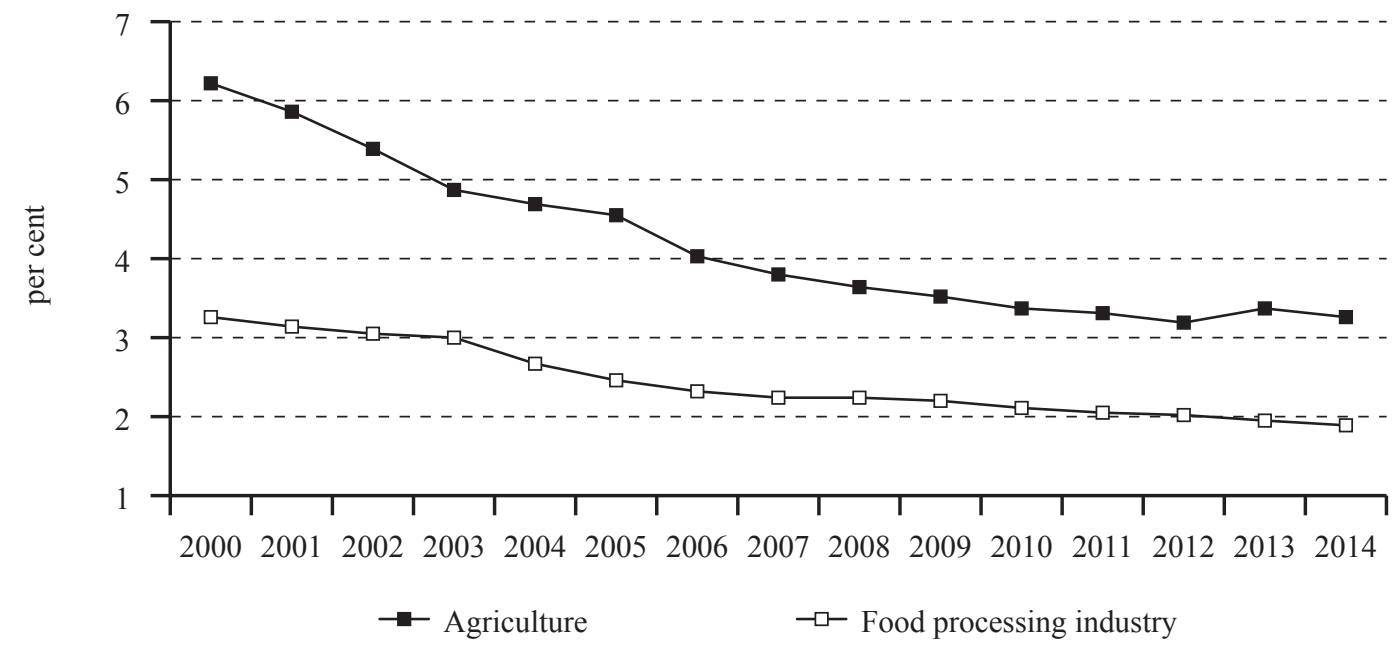

Source: SO SR 


\section{Value of agricultural production}

The value of agricultural production in Hungary totalled EUR 7.39 billion in 2014. This was a 45.1 per cent increase compared to the average of the years 2000-2002 in current prices, primarily thanks to the rise in agricultural commodity prices. In 2005 fixed prices, however, its value was 4.5 per cent below that of 2005 and only 7.2 higher than in 2000 . Hungary represented 2.0 per cent of the value of agricultural production of the EU-27 in 2014.

The values of crop and livestock production amounted to EUR 4.71 billion (2.3 per cent) and 2.67 billion (1.7 per cent) respectively in 2014. The value of agricultural production per hectare of UAA, at EUR 1.45 thousand, exceeded the EU-12 average by 10.8 per cent but was only 56.1 per cent of the EU-15 average in 2011. The value per AWU was EUR 18.0 thousand. This was 34.7 per cent above the EU-12 average but just 28.0 per cent of the EU-15 average in 2013. The share of livestock farming in the gross output of agriculture dropped from almost 50 per cent in the early 2000 s to around 35 per cent in 2014 (Figure 9), parallel to a decline in livestock numbers.

Figure 9: The share of crop production and livestock farming in the gross output of agriculture in Hungary, 2000-2014.

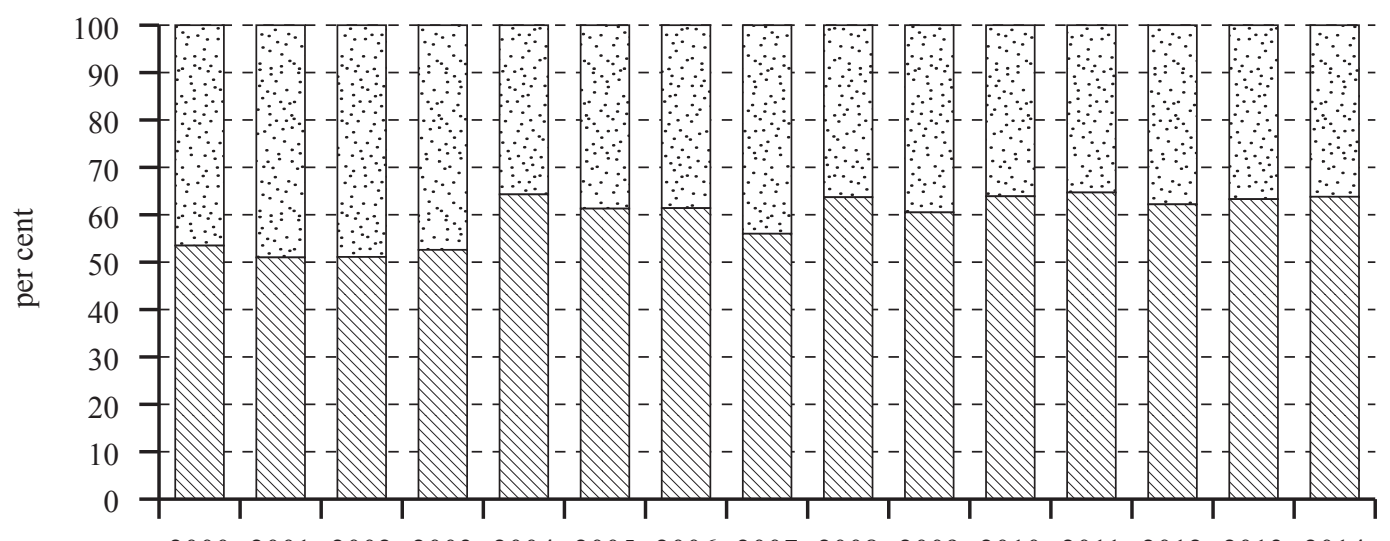

200020012002200320042005200620072008200920102011201220132014

MV Crop $\quad \because \because$ Livestock

Source: HCSO

The total output of Czech agricultural production was valued at EUR 4,635 million, about a 23.7 per cent rise (in current prices) on the recent low dip of EUR 3,547 million in 2009. This rise is, in line with other countries, largely due to the favourable development of commodity prices, although the annual rises are not as great as those experienced by some of the country's neighbours. In 2014, the Czech Republic represented 1.3 per cent of the value of agricultural production of the EU-28. The values of crop and livestock production amounted in 2014 to EUR 2.8 billion and 1.8 billion respectively.

The value of agricultural production per hectare of UAA reached EUR 1.3 thousand, and the labour productivity per AWU was EUR 12.6 thousand ( 80 per cent of the level of the EU-27 in 2013) in the Czech Republic. Up until the recent global economic downturn, the relative sizes of the Czech livestock and crop sectors were remarkably stable and roughly equal to each other. Since then, however, the value of crop production has cast an increasing shadow over livestock. This partly reflects the significant decline in livestock numbers, although other reasons (especially commodity prices) are at play since the number of livestock had been also declining previously. In 2013, crop production was estimated to be 62 per cent of the total (Figure 10). 
Figure 10: The share of crop production and livestock farming in the gross output of agriculture in the Czech Republic, 2000-2014.

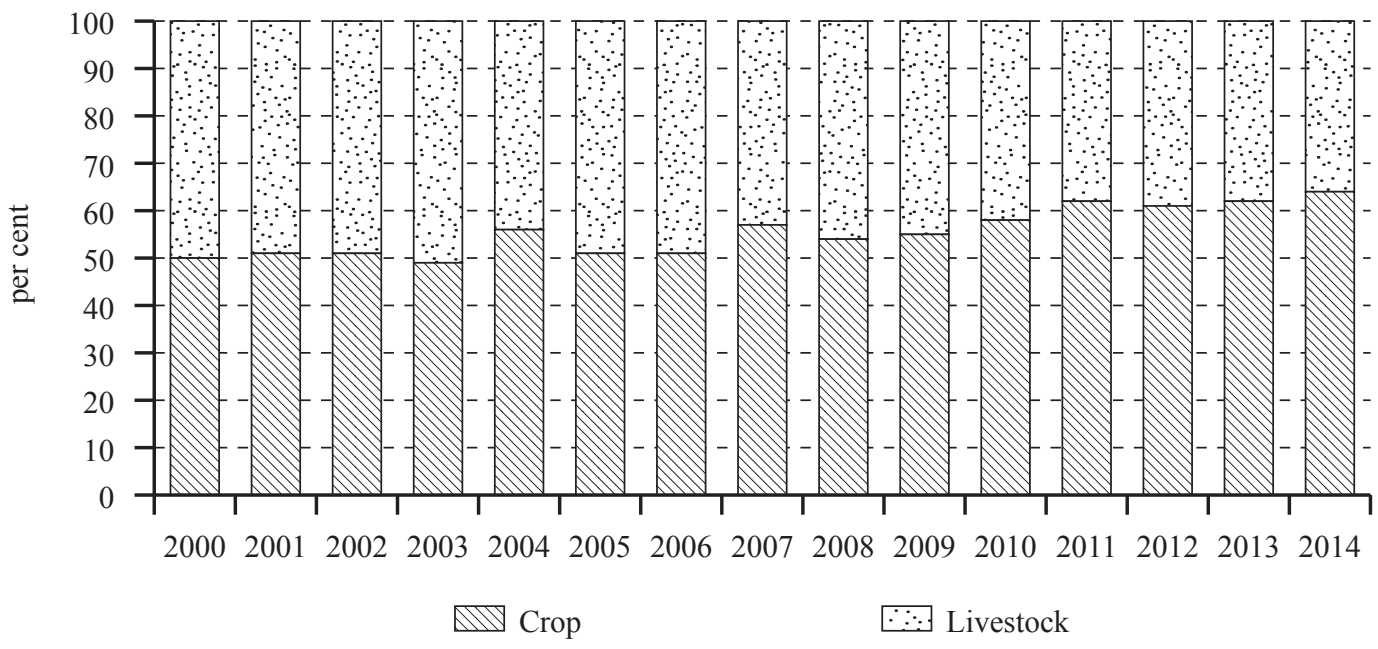

Source: CZSO

In Slovakia at the beginning of the 2000s the higher share of animal production in the gross output of agriculture was characteristic. 2004 was a good year for agriculture in Slovakia (Blaas and Varošćák, 2006). The total output was higher than the year before by 10 per cent, intermediate consumption grew only moderately and the entrepreneurial income was more than three times higher than the year before. Three components coincided in this evolution: the change in physical inputs, the price change and the implementation of the CAP support system.

Figure 11: The share of crop production and livestock farming in the gross output of agriculture in Slovakia, 2000-2014.

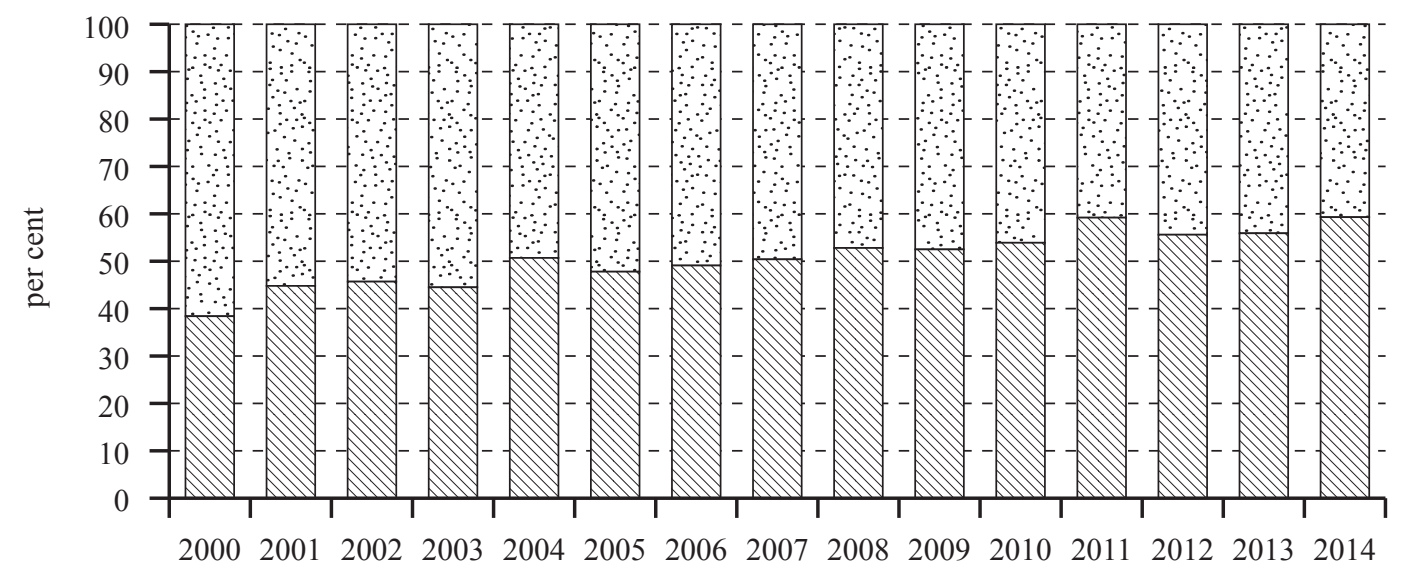

MV Crop $\because \because$ Livestock

Source: SO SR

Since 2007, the dominance of crop production in the gross output of agriculture has been characteristic in Slovakia. The value of crop production grew approximately equally under the influence of physical production growth and of the change in the support system (Figure 11). The situation 
developed in another way for livestock production. The fall of production value at basic prices was mainly due to a significant reduction of subsidies on products but also due to lower physical output.

In Hungary the value of crop production averaged EUR 4.55 billion in current prices during the period 2012-2014, a sharp increase over the EUR 2.64 billion for the period 2000-2002 ${ }^{5}$. The share of cereals and industrial crops much demanded on the export markets increased substantially, causing the share of fodder, fruits, wine, potatoes and especially vegetables production to shrink (Table 7).

Table 7: The share of major sectors in the value of crop production in Hungary, average of 2000-2002 versus 2012-2014.

EUR million

\begin{tabular}{lrrrrrrrr}
\hline Denomination & \multicolumn{1}{c}{$\mathbf{2 0 0 0}$} & \multicolumn{1}{c}{$\mathbf{2 0 0 1}$} & $\mathbf{2 0 0 2}$ & $\mathbf{a v . 0 0 - 0 2}$ & $\mathbf{2 0 1 2}$ & $\mathbf{2 0 1 3}$ & $\mathbf{2 0 1 4}$ & av.12-14 \\
\hline Cereals & $1,048.1$ & $1,107.6$ & $1,181.1$ & $\mathbf{1 , 1 1 2 . 3}$ & $2,104.3$ & $2,250.04$ & $2,375.4$ & $\mathbf{2 , 2 4 3 . 2}$ \\
\hline Industry crops & 234.2 & 357.5 & 427.6 & $\mathbf{3 3 9 . 8}$ & 945.1 & 887.2 & 921.2 & $\mathbf{9 1 7 . 8}$ \\
\hline Fodder & 96.1 & 123.0 & 128.2 & $\mathbf{1 1 5 . 8}$ & 141.5 & 172.5 & 180.6 & $\mathbf{1 6 4 . 9}$ \\
\hline Vegetables & 513.4 & 583.5 & 632.3 & $\mathbf{5 7 6 . 4}$ & 565.1 & 598.1 & 642.5 & $\mathbf{6 0 1 . 9}$ \\
\hline Potatoes $^{\text {a) }}$ & 107.6 & 116.0 & 112.5 & $\mathbf{1 1 2 . 0 3}$ & 91.1 & 116.0 & 117.0 & $\mathbf{1 0 8 . 0 3}$ \\
\hline Fruits $^{\text {Wine }}$ & 366.3 & 368.7 & 328.0 & $\mathbf{3 5 4 . 3}$ & 355.6 & 424.5 & 354.8 & $\mathbf{3 7 8 . 3}$ \\
\hline Others $^{\text {b) }}$ & 180.8 & 108.8 & 93.01 & $\mathbf{1 2 7 . 5}$ & 102.1 & 108.8 & 78.3 & $\mathbf{9 6 . 4}$ \\
\hline Total & 38.4 & 22.1 & 17.9 & $\mathbf{2 6 . 1}$ & 32.1 & 38.1 & 42.9 & $\mathbf{3 7 . 7}$ \\
\hline
\end{tabular}

a) Including seed potatoes.

b) In the case of 'wine' production the data are concerning to 2004, 2005 and 2006.

Source: HCSO

In contrast to crop production, the EUR 2.46 billion average value of livestock farming in 20002002 increased to EUR 2.66 billion during the period 2012-2014 in current prices, which was not a significant rise compared to the crop production. The share of pig meat and poultry production (these livestock sectors have been excluded from all direct aids since EU accession) contracted considerably relative to that of milk production and other sectors of livestock farming (Table 8).

Table 8: The share of major sectors in the value of livestock production in Hungary, average of 2000-2002 versus 2012-2014.

EUR million

\begin{tabular}{|c|c|c|c|c|c|c|c|c|}
\hline Denomination & 2000 & 2001 & 2002 & av.00-02 & 2012 & 2013 & 2014 & av.12-14 \\
\hline Cattle & 100.6 & 98.9 & 101.1 & 100.2 & 197.8 & 177.6 & 158.6 & 178.0 \\
\hline Pigs & 707.8 & 970.1 & 954.2 & 877.4 & 721.8 & 713.0 & 713.2 & 716.0 \\
\hline Poultry & 484.8 & 583.8 & 660.2 & 576.3 & 793.4 & 832.8 & 827.6 & 817.9 \\
\hline Milk & 495.5 & 555.1 & 605.9 & 552.2 & 535.0 & 570.7 & 618.4 & 574.7 \\
\hline Others & 51.5 & 65.3 & 102.8 & 73.2 & 81.6 & 99.5 & 84.9 & 88.7 \\
\hline Total & $2,089.7$ & $2,570.9$ & 2,711.1 & $2,457.2$ & $2,636.0$ & $2,664.6$ & $2,678.3$ & $2,659.6$ \\
\hline
\end{tabular}

Source: HCSO

\footnotetext{
For Hungary, owing to the large fluctuations in crop production, averages of three years were chosen for comparison.
} 
In the Czech Republic the value of crop production averaged EUR 2.89 billion in current prices during the period 2012-2014, a substantial increase over the EUR 1.33 billion for 2000-2002. The share of cereals and industrial crops, much due to a favourable export market situation increased substantially, the greatest 'victim' of this was the potatoes' share, marking the general decline in potato output demonstrated above (Table 9).

Table 9: The share of the major sectors in the value of crop production in the Czech Republic, average of 2000-2002 versus 2012-2014.

EUR million

\begin{tabular}{lrrrrrrrr}
\hline Denomination & $\mathbf{2 0 0 0}$ & $\mathbf{2 0 0 1}$ & $\mathbf{2 0 0 2}$ & $\mathbf{a v . 0 0 - 0 2}$ & $\mathbf{2 0 1 2}$ & $\mathbf{2 0 1 3}$ & $\mathbf{2 0 1 4}$ & av.12-14 \\
\hline Cereals & 551.6 & 787.8 & 714.2 & $\mathbf{6 8 4 . 5}$ & $1,287.1$ & $1,253.1$ & $1,233.6$ & $\mathbf{1 , 2 5 8 . 0}$ \\
\hline Industry crops & 287.2 & 388.0 & 354.5 & $\mathbf{3 4 3 . 2}$ & 757.2 & 794.2 & 780.9 & $\mathbf{7 7 7 . 4}$ \\
\hline Fodder & 235.9 & 190.1 & 239.2 & $\mathbf{2 2 1 . 7}$ & 409.3 & 452.4 & 466.8 & $\mathbf{4 4 2 . 8}$ \\
\hline Vegetables & 76.3 & 77.9 & 98.9 & $\mathbf{8 4 . 4}$ & 205.6 & 203.3 & 197.8 & $\mathbf{2 0 2 . 3}$ \\
\hline Potatoes & 147.3 & 95.4 & 145.0 & $\mathbf{1 2 9 . 2}$ & 76.5 & 98.6 & 99.8 & $\mathbf{9 1 . 7}$ \\
Fruits & 64.6 & 49.9 & 55.4 & $\mathbf{5 6 . 6}$ & 50.9 & 52.9 & 47.0 & $\mathbf{5 0 . 3}$ \\
\hline Wine & 16.3 & 16.6 & 22.0 & $\mathbf{1 8 . 3}$ & 30.8 & 36.0 & 29.2 & $\mathbf{3 2 . 0}$ \\
\hline Others & 18.1 & 17.4 & 23.2 & $\mathbf{1 9 . 6}$ & 33.0 & 29.9 & 30.7 & $\mathbf{3 1 . 2}$ \\
\hline Total & $\mathbf{1 , 3 9 7 . 4}$ & $\mathbf{1 , 6 2 3 . 2}$ & $\mathbf{1 , 6 5 2 . 5}$ & $\mathbf{1 , 5 5 7 . 7}$ & $\mathbf{2 , 8 5 0 . 5}$ & $\mathbf{2 , 9 2 0 . 4}$ & $\mathbf{2 , 8 8 5 . 8}$ & $\mathbf{2 , 8 8 5 . 6}$ \\
\hline
\end{tabular}

Source: CZSO

In contrast to crop production, the EUR 1.57 billion average value of livestock farming in the period 2000-2002 increased to EUR 1.82 billion during the period 2012-2014 in current prices only, which was much less compared to the crop production. Pig production was the greatest 'victim' with a decrease from EUR 500 million on average in 2000-2002 to EUR 363 million on average in 20122014 (Table 10).

Table 10: The share of the major sectors in the value of livestock production in the Czech Republic, average of 2000-2002 versus 2012-2014.

\begin{tabular}{|c|c|c|c|c|c|c|c|c|}
\hline Denomination & 2000 & 2001 & 2002 & av.00-02 & 2012 & 2013 & 2014 & av.12-14 \\
\hline Cattle & 209.1 & 160.4 & 177.1 & 182.2 & 265.4 & 256.1 & 240.7 & 254.1 \\
\hline Pigs & 453.7 & 582.0 & 464.9 & 500.2 & 370.6 & 368.8 & 350.2 & 363.2 \\
\hline Poultry & 129.7 & 182.8 & 200.8 & 171.1 & 231.1 & 228.7 & 225.1 & 228.3 \\
\hline Milk & 534.7 & 554.6 & 640.1 & 576.5 & 815.8 & 862.5 & 965.0 & 881.1 \\
\hline Others & 92.4 & 99.0 & 85.2 & 92.2 & 107.6 & 89.4 & 91.1 & 96.0 \\
\hline Total & $1,419.5$ & $1,578.9$ & $1,568.2$ & $1,522.2$ & $1,790.4$ & $1,805.5$ & $1,872.1$ & $1,822.7$ \\
\hline
\end{tabular}

Source: SO SR

In Slovakia, the value of crop production on average at current prices increased by 47.6 per cent from EUR 851.5 million in the period 2000-2002 to EUR 1,257.2 million in the period 2012-2014. The production value of cereals, industrial crops and vegetables increased in relation to the good sale conditions for agri-food markets. The production value of grape, fruit and potatoes decreased by 61.4 per cent, due to the decline in the growing area caused by the increased climate-related risk of production and competition from neighbouring countries (Table 11). 
Table 11: The share of the major sectors in the value of crop production in Slovakia, average of 2000-2002 versus 2012-2014.

EUR million

\begin{tabular}{lrrrrrrrr}
\hline Denomination & $\mathbf{2 0 0 0}$ & $\mathbf{2 0 0 1}$ & $\mathbf{2 0 0 2}$ & $\mathbf{a v . 0 0 - 0 2}$ & $\mathbf{2 0 1 2}$ & $\mathbf{2 0 1 3}$ & $\mathbf{2 0 1 4}$ & av.12-14 \\
\hline Cereals & 253.7 & 399.6 & 409.3 & $\mathbf{3 5 4 . 2}$ & 625.4 & 597.9 & 647.1 & $\mathbf{6 2 3 . 5}$ \\
\hline Industry crops & 68.3 & 99.7 & 116.1 & $\mathbf{9 4 . 7}$ & 232.2 & 226.7 & 257.4 & $\mathbf{2 3 8 . 8}$ \\
\hline Fodder & - & - & - & - & - & - & - & - \\
\hline Vegetables & 106.3 & 127.6 & 109.0 & $\mathbf{1 1 4 . 3}$ & 150.7 & 180.5 & 133.6 & $\mathbf{1 5 4 . 9}$ \\
\hline Potatoes & 68.5 & 48.4 & 83.7 & $\mathbf{6 6 . 9}$ & 23.8 & 23.8 & 29.7 & $\mathbf{2 5 . 8}$ \\
\hline Fruits & 42.6 & 44.9 & 31.5 & $\mathbf{3 9 . 7}$ & 26.3 & 29.2 & 22.6 & $\mathbf{2 6 . 0}$ \\
\hline Wine & 23.9 & 26.9 & 18.7 & $\mathbf{2 3 . 2}$ & 22.1 & 22.1 & 14.2 & $\mathbf{1 9 . 5}$ \\
\hline Others & 67.6 & 126.5 & 126.1 & $\mathbf{1 0 6 . 7}$ & 109.7 & 107.6 & 148.4 & $\mathbf{1 2 1 . 9}$ \\
\hline Total & $\mathbf{6 7 1 . 0}$ & $\mathbf{9 2 5 . 5}$ & $\mathbf{9 5 4 . 2}$ & $\mathbf{8 5 1 . 5}$ & $\mathbf{1 , 2 3 0 . 6}$ & $\mathbf{1 , 2 4 0 . 9}$ & $\mathbf{1 , 3 0 0 . 1}$ & $\mathbf{1 , 2 5 7 . 2}$ \\
\hline
\end{tabular}

Source: SO SR

In contrast to crop production, the average value of livestock production decreased from EUR 1,118.59 million in the period 2000-2002 to EUR 946.33 million in the period 2012-2014 in current prices. The biggest decrease was in pigs, where the average value of production was 2.7 times smaller in 2012-2014 than in 2000-2002 (Table 12).

Table 12: The share of the major sectors in the value of livestock production in Slovakia, average of 2000-2002 versus 2012-2014.

\begin{tabular}{lcccrcrrr}
\hline Denomination & $\mathbf{2 0 0 0}$ & $\mathbf{2 0 0 1}$ & $\mathbf{2 0 0 2}$ & $\mathbf{a v . 0 0 - 0 2}$ & $\mathbf{2 0 1 2}$ & $\mathbf{2 0 1 3}$ & $\mathbf{2 0 1 4}$ & av.12-14 \\
\hline Cattle & 158.77 & 149.80 & 150.10 & $\mathbf{1 5 2 . 8 9}$ & 154.53 & 152.77 & 149.9 & $\mathbf{1 5 2 . 4}$ \\
\hline Pigs & 364.44 & 399.75 & 377.68 & $\mathbf{3 8 0 . 6 2}$ & 142.87 & 155.45 & 127.63 & $\mathbf{1 4 1 . 9 8}$ \\
\hline Poultry & 125.07 & 148.58 & 134.77 & $\mathbf{1 3 4 . 1 4}$ & 114.02 & 123.42 & 97.61 & $\mathbf{1 1 1 . 6 8}$ \\
\hline Milk & 286.16 & 301.43 & 330.15 & $\mathbf{3 0 5 . 9 1}$ & 278.27 & 336.63 & 311.64 & $\mathbf{3 0 8 . 8 5}$ \\
\hline Others & 143.4 & 143.51 & 142.17 & $\mathbf{1 4 3 . 0 3}$ & 292.93 & 210.98 & 190.35 & $\mathbf{2 3 1 . 4 2}$ \\
\hline Total & $\mathbf{1 , 0 7 7 . 8 4}$ & $\mathbf{1 , 1 4 3 . 0 7}$ & $\mathbf{1 , 1 3 4 . 8 7}$ & $\mathbf{1 , 1 1 8 . 5 9}$ & $\mathbf{9 8 2 . 6 2}$ & $\mathbf{9 7 9 . 2 5}$ & $\mathbf{8 7 7 . 1 3}$ & $\mathbf{9 4 6 . 3 3}$ \\
\hline
\end{tabular}

Source: SO SR

\section{Incomes in agriculture}

Income is a key measure for determining the viability of the agricultural sector. The nominal factor income of the agricultural industry (the remuneration of all factors of production: land, capital, labour) in the EU-28 was EUR 153.7 billion in basic price terms in 2014 (Eurostat, 2015). After 2004, owing to the introduction of EU direct payments, farm incomes in Hungary increased in nominal terms. The transfer efficiency of these payments, however, eroded significantly as they were gradually capitalised into land lease prices and into agricultural input prices (Kovács et al., 2009).

In Hungary in 2014 the average monthly gross income per employee was EUR 770.1. The figure for the agriculture, forestry and fisheries sector (EUR 584.0) was higher only than tourism (EUR 495.3). The average monthly gross income per employee in the construction industry - hit most by the economic crisis - was only slightly higher, EUR 601.5, but in education it reached EUR 796.8 and in industry EUR 835.4. Information and communication (EUR 1,456.1) followed financing and 
insurance (EUR 1,574.7), the highest income sector. Factor incomes, comprising compensation of employees by, and operating surplus of, producers in Hungarian agriculture, totalled EUR 7.8 billion in 2014, according to the Economic Accounts for Agriculture (EAA), This represents a 272.6 per cent growth over 2000 in current prices. Factor incomes per hectare of UAA reached EUR 0.834 thousand, but lagged behind the EU-27 average by 28.8 per cent. Factor incomes per AWU were 47.5 per cent below the EU-27 average, at EUR 8.387 thousand, which is a clear signal of the relative inefficiency of agricultural production technologies in 2014.

In the Czech Republic the average monthly gross earnings per employee were EUR 930 in 2014. Among the sectors, accommodation and food service activities represented the lower, and financing and insurance the higher end at EUR 510 and EUR 1,748, respectively. The agriculture, forestry and fishing sector, at EUR 770, was substantially below the national average. According to the EAA, factor incomes, comprising compensation of employees by, and operating surplus of, producers in Czech agriculture, totalled EUR 4.1 billion in 2014. This represents a 335.5 per cent growth over 2000 in current prices. Factor incomes per hectare of UAA reached EUR 0.590 thousand in 2014, but lagged behind the EU-27 average by 49.6 per cent. Factor incomes per AWU were EUR 19.633 thousand in 2014, 237.6 per cent compared to 2005 (EU 27 - 122.9 per cent).

In 2014 the average monthly gross earnings per employee in Slovakia was EUR 964. Among the sectors, accommodation and food service activities represented the lowest average monthly earnings with EUR 580, and the highest average monthly earnings are characteristics by information and communication with EUR 1,791 and by financial and insurance activities with EUR 1,627. The average nominal monthly earnings were only EUR 776 in the agriculture, forestry and fisheries sector. The monthly earnings in construction and education were EUR 851 and EUR 807 respectively in 2014. According to the EAA, factor incomes, comprising compensation of employees by, and operating surplus of, producers in Slovakian agriculture, totalled EUR 1.5 billion in 2014. This represents a 213.5 per cent growth over 2000 in current prices. Factor incomes per hectare of UAA reached EUR 0.392 thousand, but lagged behind the EU-27 average by 66.4 per cent. Factor incomes per AWU were EUR 13.845 thousand, 13.4 per cent below the EU-27 average.

\section{State of rural areas}

Owing to the development of infrastructure over the past decade, and the expansion and increase in the quality level of basic services, regional disparities have been moderated in all three countries, lifestyle differences have declined substantially, and farms in some rural areas are moving in different developmental pathways depending on their economic conditions. The OECD (2012) and Eurostat criteria, based on the proportion of population living in areas with a population density less than 150 people $/ \mathrm{km}^{2}$, are used for defining NUTS 3 regions as 'predominantly urban', 'intermediate' or 'predominantly rural' in the Rural Development Programmes.

In Hungary the City of Budapest is the only predominantly urban NUTS 3 region. In the Czech Republic as of 1 January 2012 the only predominantly rural NUTS 3 region was the Vysočina Region, while the only predominantly urban region was the City of Prague. There are six intermediate regions covering the suburbs of the largest county seats, while the rest are predominantly rural regions. In Slovakia only the Bratislava NUTS 3 region is predominantly urban. Banská Bystrica region and Nitra region are two predominantly rural regions, and five regions are intermediate.

Employment in the predominantly rural areas continues to be the highest in the Czech Republic (Figure 12). The lowest employment rates were in Hungary, but in 2014 the rate for Hungary was higher than in Slovakia. In Slovakia the employment rate in urban areas was overall higher in 2014 (70.9 per cent) as it was at the beginning of the reference period (67.3 per cent). Unemployment levels and rates move in a cyclical manner, largely related to the general business cycle. However, other 
factors such as labour market policies and demographic developments may also influence their short and long-term evolution (Eurostat, 2016).

Figure 12: Employment rates in the predominantly rural areas of Hungary, the Czech Republic and Slovakia, 2004-2014.

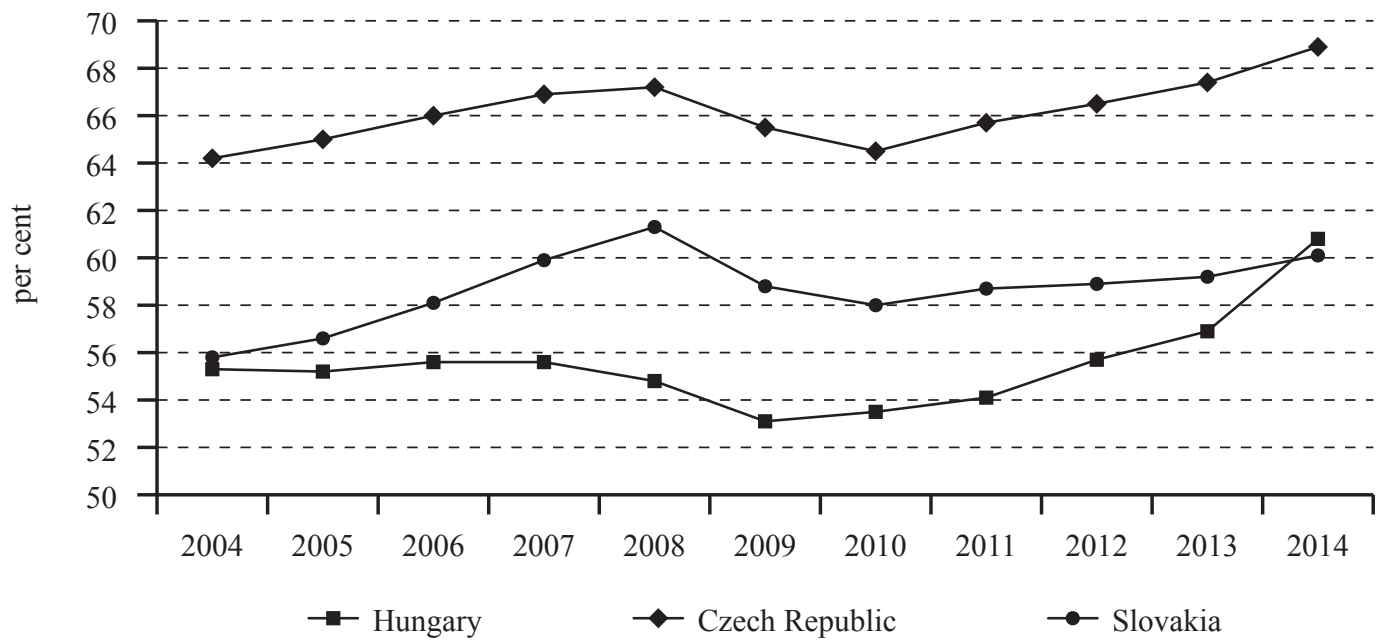

Source: Eurostat

Two thirds of Hungary's territory is rural, where 46.9 per cent of the population live. The level of employment is the lowest in predominantly rural (and intermediate) regions, especially in the predominantly rural eastern, north-eastern and southern-Transdanubian NUTS 3 regions of the country. Thus the rural areas generate just one third of the total Gross Value Added (GVA) and provide employment for 39.3 per cent of the workforce (Figure 13). Only a few people in rural areas can find jobs that provide an adequate standard of living. The role of agriculture in direct employment is even decreasing in areas of agricultural dominance.

Figure 13: Area, population, GDP and employment according to rurality in Hungary, 2014.

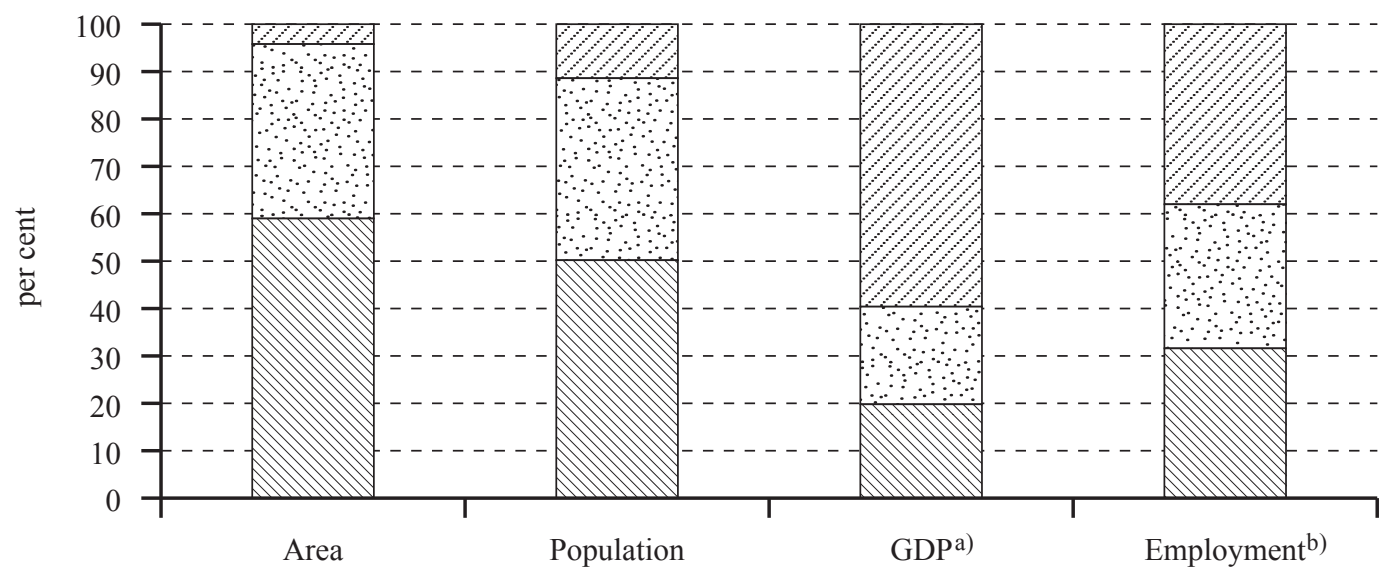

MIV Predominantly rural $\quad \because \because$ Intermediate $\quad \because$ Predominantly urban 
The economic backwardness of rural areas has not declined in recent years. In rural areas in 2011 the GDP per capita was EUR 7.5 thousand per person (Figure 14), i.e. less than three-quarters of the national average (EUR 7.7 thousand per person) and only one-third of the figure for Budapest (EUR 22.6 thousand per person). The growing backwardness of the rural areas is shown by the economic inactivity rate of the rural population as well.

In rural areas, agribusiness traditionally plays a major role in labour use and income generation. This indicates the sector's contribution to gross value added, which in rural areas decreased from 9.3 per cent in 2000 to 6.6 per cent to 2010 , but it is still nearly twice the national average (3.6 per cent). The index in rural areas increased again in 2011. The increased employment in agriculture in recent years was primarily due to the simplification of the legal and tax background of casual employment and tightening labour inspections, this means that, this was a result of the 'whitening' of illegal 'black' employment.

Figure 14: GDP per capita in rural areas in Hungary, 2001-2011.

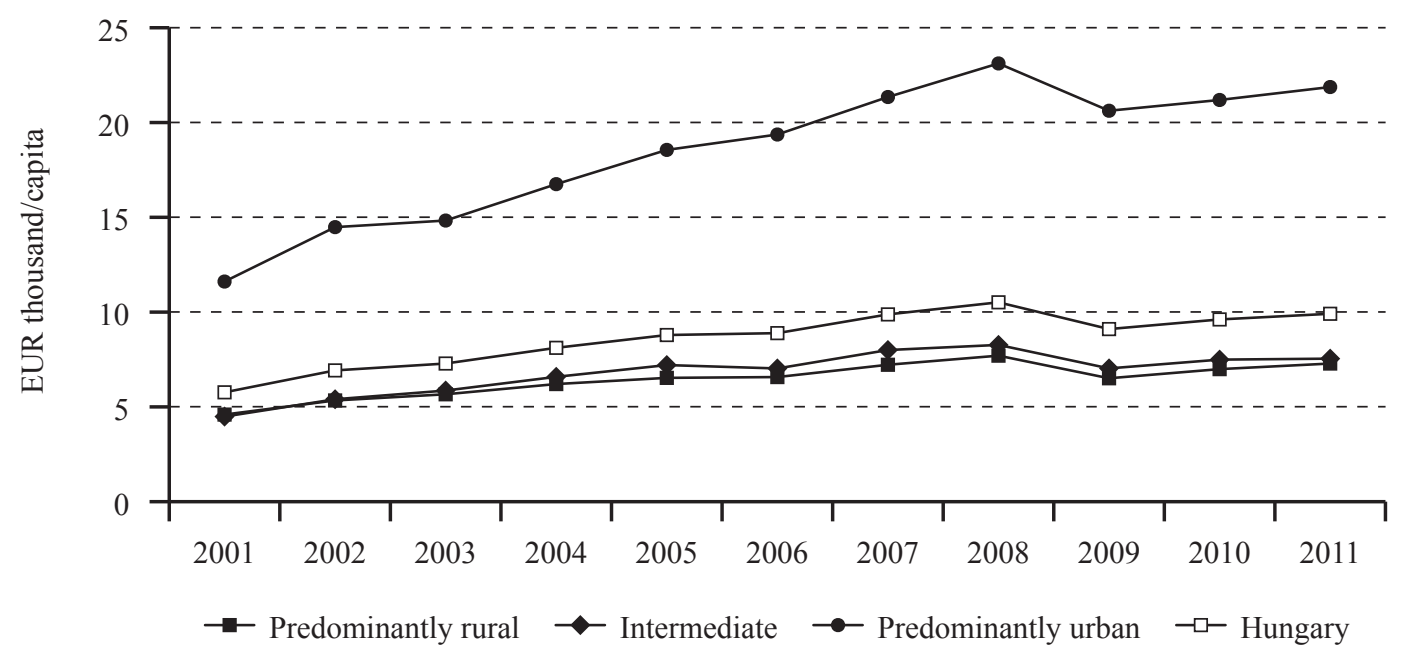

Source: $\mathrm{HCSO}$

The regional disparities in employment have increased in recent times. The service sector and hence the business sector are still generally underdeveloped. The availability of skilled labour is limited. The rate of unemployment is high and persistent mainly for unskilled social groups while the more educated and younger people migrate from the rural areas; thus the rural population is in decline. From 2001 to 2013 about 107 thousand people from rural areas moved to the intermediate and urban areas (Figure 15).

In the Czech Republic, predominantly rural areas occupy 48.4 per cent of the territory, the intermediate regions 37 per cent and the predominantly urban areas 14.6 per cent. In terms of population the predominantly rural areas represent 24.2 per cent, the intermediate areas 42.9 per cent and the predominantly urban areas 32.9 per cent of the population in 2014 (Figure 16). These ratios have been more or less consistent, without any major changes, throughout the period 2007-2013. With regard to the average population density, it increased slightly from 131 to almost 138 inhabitants per $\mathrm{km}^{2}$. 
Figure 15: Internal migration in rural areas in Hungary, 2001-2013.

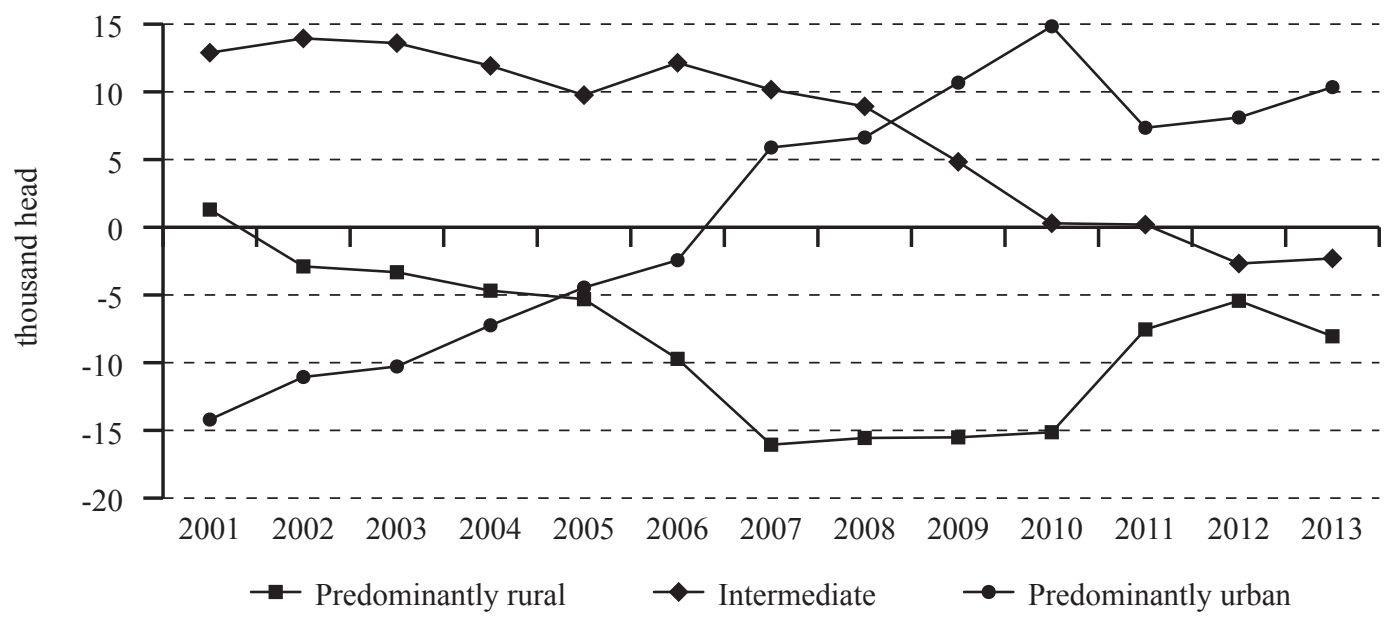

Source: HCSO

Figure 16: Area, population, GDP and employment according to rurality in the Czech Republic, 2014.

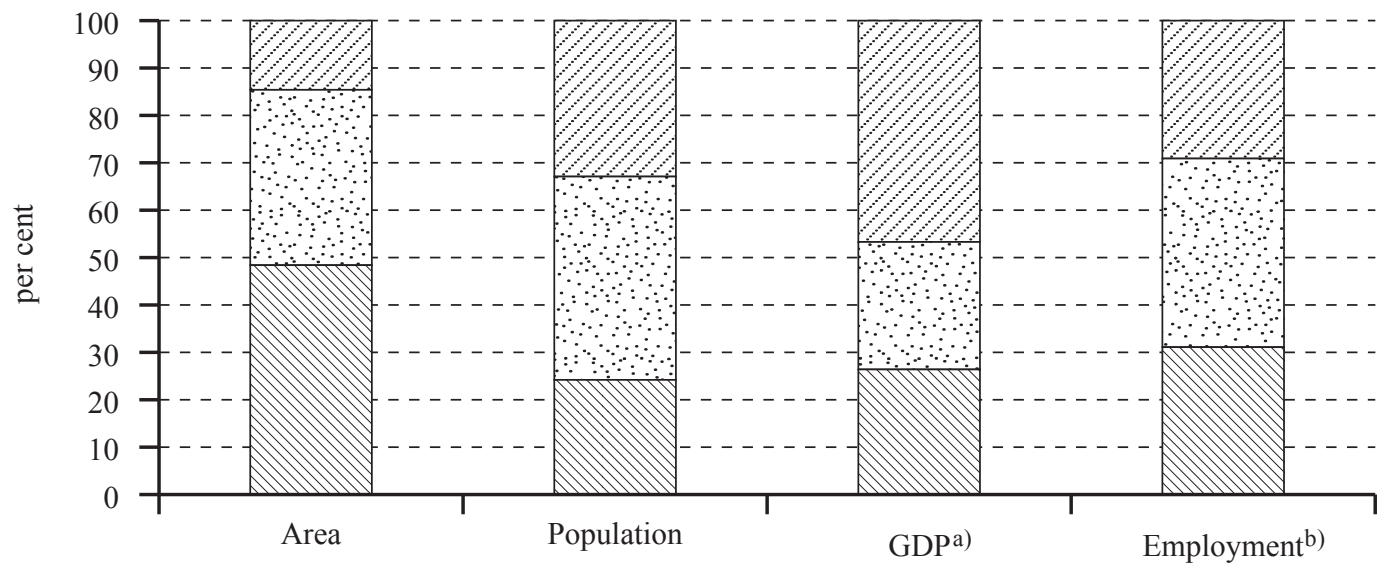

MIV Predominantly rural

$\therefore \because$ Intermediate

Predominantly Urban

a) Data for the year 2012; ${ }^{\text {b) }}$ Data for the year 2013.

Source: Eurostat

The overall unemployment rate in the Czech Republic in 2014 was 6.1 per cent, and it was higher for women ( 7.4 per cent) than for men ( 5.1 per cent). Nevertheless, in comparison with the EU average (10.2 per cent), the level of unemployment in the Czech Republic is relatively low (about 4 percentage points below the EU average). Historically, women have been more affected by unemployment than men. In 2008 there were 3.9 applicants for each job vacancy; this number increased up to 18 applicants, of whom the majority were aged between 21 and 30 years.

Since the end of 2008, when the impact of the global economic recession began, the Czech economy has been undergoing a significant change. According to Czech Central Statistical Office (CZSO) data, the annual growth achieved in terms of GDP in 2005 and 2006 was about 7 per cent, in 2007 the figure was 5.7 per cent, while in 2008 it was only 3.1 per cent. The economic recession of late 
2008 and 2009 meant that in 2009 there was a decrease in GDP of 4.7 per cent (Figure 17). A slight recovery in the economy occurred in 2010, when the growth in GDP reached 2.7 per cent. In 2011 the GDP grew by only 1.7 per cent and in 2012 a fall of 1.2 per cent was recorded. The reasons for this were primarily the impact of fiscal consolidation associated with its relatively negative impact on both household consumption and investment. The economy was still in a negative output gap and there was a high degree of uncertainty resulting primarily from concerns regarding the European economy within the context of the ongoing debt crisis. The forecast assumed stagnation of the GDP.

Figure 17: GDP per capita in rural areas in the Czech Republic, 2000-2011.

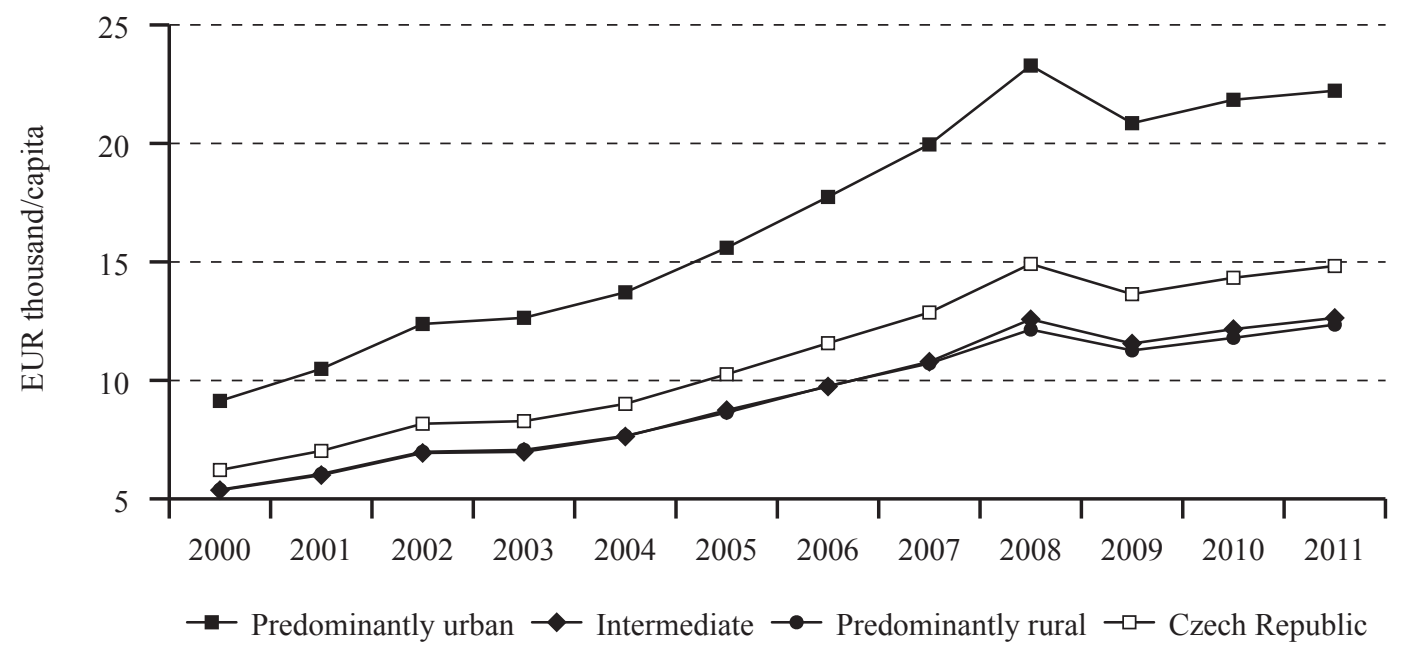

Source: Eurostat

Fifty-nine per cent of Slovakia's territories, where half of the total population lives, are rural. These areas generate only 19.8 per cent of the total GDP and provide employment for 31.6 per cent of the work force (Figure 18).

Figure 18: Area, population, GDP and employment according to rurality in Slovakia, 2014.

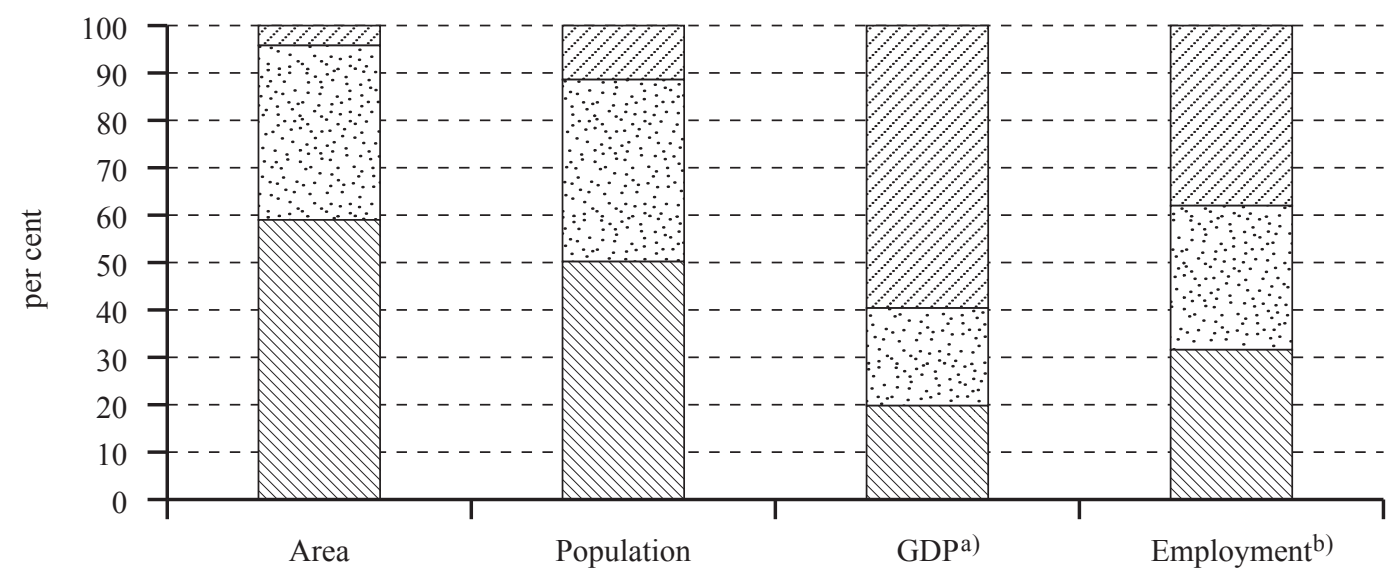

$\mathbb{Q W}$ Predominantly rural $\quad \because \because$ Intermediate $\quad \because$ Predominantly urban 
GDP per capita in Slovakia increased in the period 2000-2012 but this trend was reversed under the impact of the financial and economic crisis in 2009. There was a revival in 2010 and the pace of economic growth increased (Figure 19). GDP increased faster in urban areas than in rural areas. While the GDP per capita was 2.6 times higher in urban areas than in rural areas in 2000, it was already 3.1 times higher in 2009. The employment rate in Slovakia increased in the period 20002008, there was a sharp decline due to the financial and economic crisis in 2009, and since 2011 the employment rate has shown slow but steady growth.

Figure 19: GDP per capita in rural areas in Slovakia, 2000-2012.

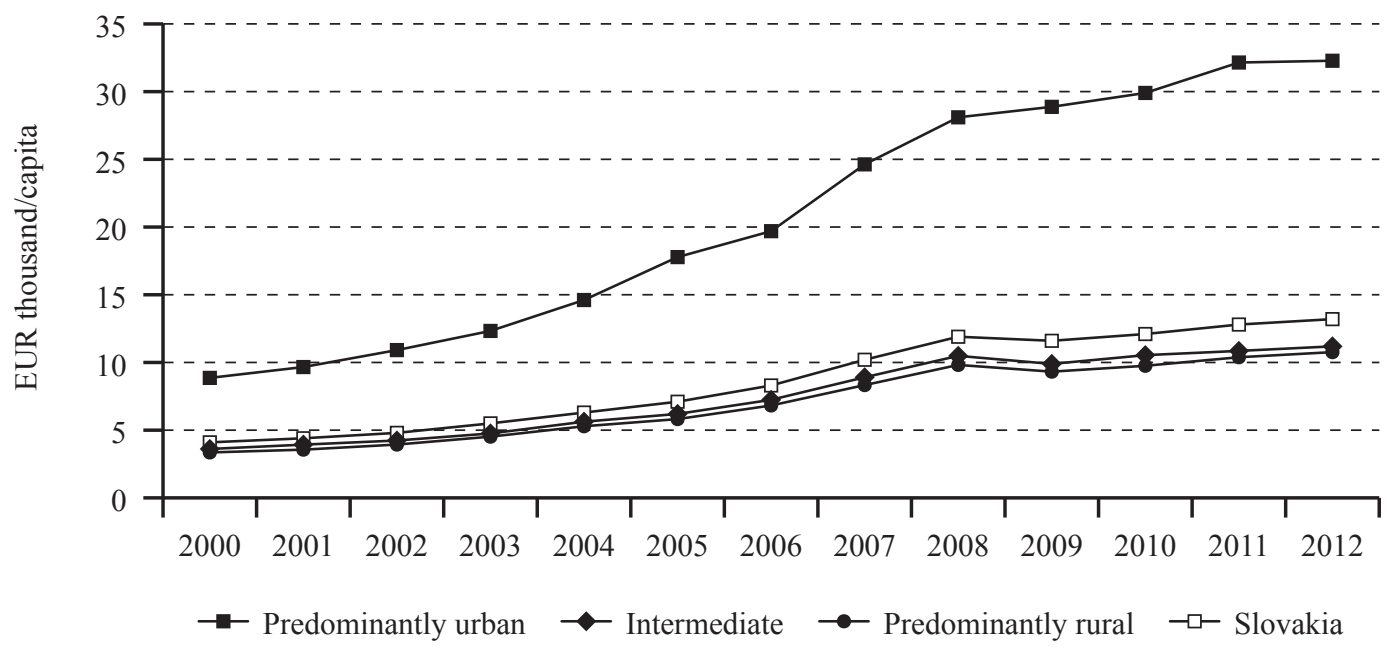

Source: Eurostat

The demographic balance in rural areas had an equable trend in the period 2000-2014. It was 3.2 times higher in urban areas than in rural areas (Figure 20). The situation was the same in urban and intermediate areas.

Figure 20: Demographic balance in rural areas in Slovakia, 2002-2014.

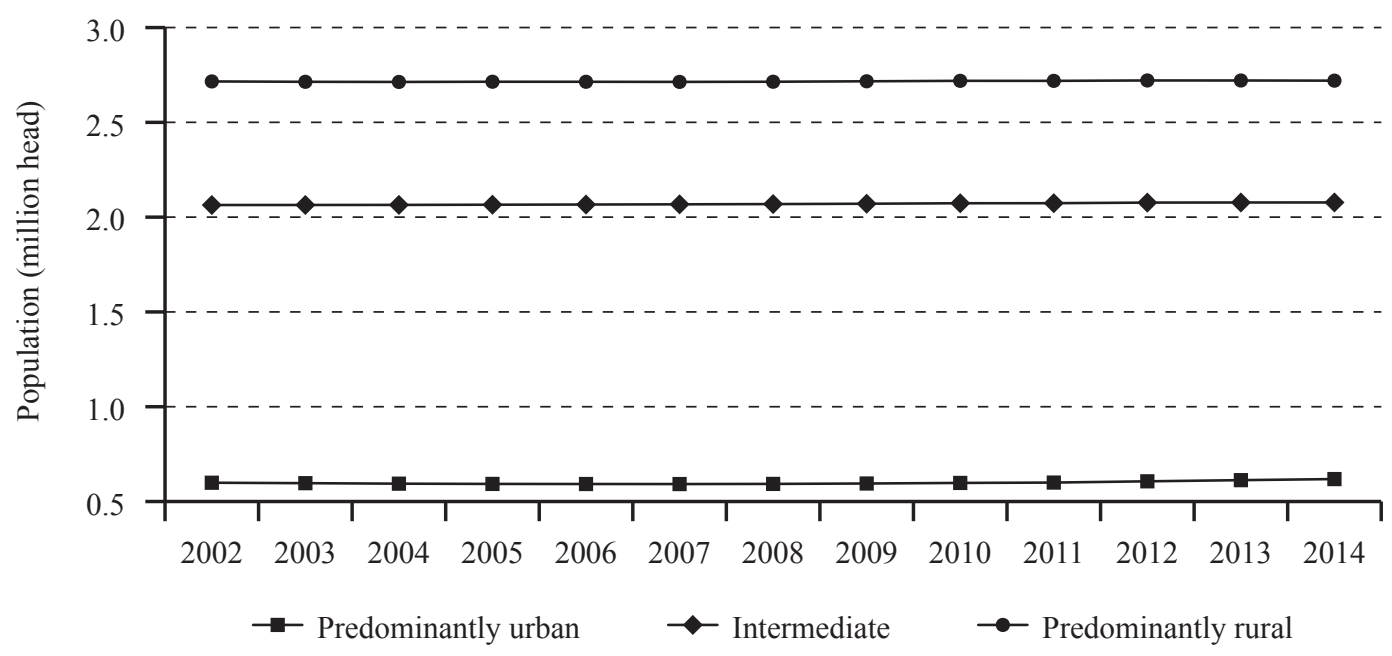

Source: Eurostat 


\section{Conclusions}

Hungary, the Czech Republic and Slovakia are three neighbouring, medium-sized Central European countries which have had a shared history since at least the middle of the twentieth century. After around four decades of a socialist economy, each went through a period of political and economic change from 1989 onwards (the Czech Republic and Slovakia initially as two parts of one country) prior to joining the EU in 2004. The analyses presented in this chapter have shown that the agro-food sectors and the rural areas of the three countries have been substantially affected by the events of recent decades. In particular, while farmers have benefitted from financial support through the CAP, the elimination of trade barriers, while opening up new markets, have exposed both farmers and the rest of the agro-food chain in the three countries to competition from other EU Member States (MSs). Employment in farming has declined in parallel with farm restructuring, and uncompetitive agro-food businesses have closed. Superimposed on these developments are several other trends and events, not least the general decline of many of the rural territories of the three countries (an experience shared with rural areas in many other parts of Europe), most clearly illustrated by the ageing of the population as mainly younger residents move to urban areas, and the financial and economic crisis of 2008 onwards. This chapter offers just a brief introduction to some of the developments that have occurred, especially during the period from 2004. The implementation of the CAP, trends in agricultural land ownership and related issues, the impacts of the changes outlined above on the competitiveness and profitability of crop production and the milk and pigmeat sectors, and of the food industry of the three countries, are explored in more detail in the following chapters. 



\title{
Implementation of the new CAP - a comparative analysis
}

\author{
VÁSÁRY, Viktória ${ }^{1}$, BARTOŇ, Petr², BOZIK, Marian ${ }^{3}$ \\ and HUMPÁL, Jaroslav ${ }^{2}$
}

\section{Introduction}

The social-economic transition (Szanyi, 2013) in each of the post-socialist countries ${ }^{4}$ caused a decline in economic performance. At the beginning of the 1990s the accumulated efficiency and structural problems came to the surface. Economic relations within countries and among countries were disarranged. Decreasing real income, increasing unemployment and the fall in consumption, and the cessation of the Council for Mutual Economic Assistance (COMECON) had a negative impact on economic situations. The gap between the level of development in 'Eastern Europe' and that in 'Western Europe' became deeper. By the middle of the 1990s most of the countries had overcome the most difficult years of the transition. Agriculture was the biggest loser as a result of the change in the production structure. The process - the decline in the share of agriculture in GDP - lasted several decades in Western-Europe, but only 2-3 years in Central and Eastern European countries (CEECs). In the CEECs the decline in the rate of agricultural production was caused not only by the rapid increase in the ratio of other sectors, but the decrease in the volume of agricultural production, too. The transitional crisis was characterised by the deterioration of other basic agricultural indicators too, such as investments, use of inputs, per capita food consumption, terms of trade or trade balance (Evangelos, 2010; Liefert and Swinnen, 2002, Brooks and Nash, 2002, Macours and Swinnen, 2000, EC DG AGRI 2002a, 2002b and 2002c). A further common characteristic is that the production of animal husbandry has fallen to a greater extent than that of plant production. The problem is that the decline and the long lasting depression in agricultural production persisted into the period when general economic growth started up. So depression became specific to agriculture ${ }^{5}$ in the second half of the 1990s.

Despite the transitional crisis, the CEECs, including the Czech Republic, Slovakia and Hungary, conducted their own separate and independent negotiations with the European Union (EU), before the date of their accession, regarding the terms and condition of entering the CAP.

\footnotetext{
Research Institute of Agricultural Economics, Budapest, Hungary.

Institute of Agricultural Economics and Information, Prague, Czech Republic.

National Agricultural and Food Centre - Research Institute of Agricultural and Food Economics, Bratislava, Slovak Republic.

The Czech Republic and Slovakia are constituent parts of the former federal state of Czechoslovakia, peacefully dissolved in 1993. After years of common planning of all output, including agriculture, the two countries started to undertake independent agricultural policies. For example, in the Czech Republic, agricultural support (predominantly from domestic taxation) grew at an average annual rate of 22 per cent between 1995 and 2001 (Kř́stková and Golová, 2011), before plateauing after the turn of the century until the accession to the EU in 2004. This expenditure was only partly caused by inflation which was generally relatively low (less than 5 per cent per annum), most of which was aimed at restructuring after some 40 years of collectivisation.

5 For example, in Hungary agricultural policy was not able to reach a genuine solution regarding the transformational crisis and depression, and the structural problems of the agriculture. The structural changes took an unfavourable direction; the polarisation proceeded as some kind of 'drift'. A comprehensive concept dealing with important questions was not carried out for several years. The agricultural policy was able neither to manage the transformational crisis and the structural problems emerging in agriculture, nor to take stock of the economic and social political connections of agriculture in a wider sense and to build these connections into its goal- and tool-system. (Halmai and Vásáry, 2007).
} 
Prior to 2004 the Special Accession Programme for Agriculture and Rural Development (SAPARD Programme) 6 assisted the implementation of the Community acquis, supported measures to enhance efficiency and competitiveness in farming and the food industry and to create employment and sustainable economic development in rural areas. (EC, 2001; Ministerstvo zemědělství, 2006; Buchta, 2005)

Since accession to the EU, Czech, Slovak and Hungarian farmers have had access to Pillar 1 measures, i.e. market measures (export refunds, intervention) and direct payments, and Pillar 2 funds. The chapter, however, focuses only on direct payments of Pillar 1 and there is no intention to examine market or rural development measures and national programmes. (RDP measures are described in Chapter Effects of Rural Development Programmes.)

Because of the large differences between the level of then existing subsidies and those enjoyed by the incumbent 15 EU members, and because of the threat that immediate introduction of 100 per cent direct payments would have served to freeze existing structures and to hamper modernisation, a gradual system of adaptation was followed on a sliding scale. So the agricultural support in the countries concerned consisted of two large components: Single Area Payment Scheme (SAPS) and the Complementary National Direct Payments (CNDP or top-up) ${ }^{7}$. The former was intentionally set at below the EU-15 levels and was supposed to increase gradually towards standard levels over the first decade. Member States received 25 per cent of the full EU rate in 2004, 30 per cent in 2005, 35 per cent in 2006, 40 per cent in 2007 and from 2008 onwards an additional 10 per cent annually. To make up some of the shortfall, the latter sum could be financed by the national government to partially offset the gap from EU-15 levels.

\footnotetext{
"The SAPARD programme had very good absorption capacity, owing to the fact that 100 per cent of the available budget was used by the Candidate Countries. The measures with the highest rate of use were as follows: 'Investments in agricultural holdings', 'Processing and marketing of agricultural and fishery products', 'Improving structures for quality, veterinary and plant-health controls', 'Agricultural production methods protecting environment and maintaining countryside'. Unfortunately, originally, planned measures were not implemented in more than half of the eight countries (EE, HU, LV, LT, and PL)". Final financial allocation amounted to EUR 122 million in the Czech Republic, EUR 213 million in Hungary and EUR 102 million in the Slovak Republic. Measures with the highest financial shares were the same in all three countries, namely 'Processing and marketing' (CZ: 20 per cent, HU and SK: 33-33 per cent) and 'Investment in agricultural holdings '(CZ: 20 per cent, HU: 37 per cent, SK: 31 per cent.

"The implementation of the SAPARD programme, on the one hand, has helped to reduce regional disparities in the vertical spatial approach by the diversion of the bulk of funding to the economically less favoured southern areas of Slovakia lagging behind in terms of infrastructure. On the other hand, though, it has increased the regional disparities in the horizontal spatial view with regard to the fact that most of the funding is spent in the developed regions of western Slovakia. Eastern Slovakia thus has become a disadvantaged and minority recipient of the financial assistance under this programme" (Buchta, 2005).

I $n$ the Czech Republic "the Programme has produced a wide range of positive results and impacts, such as increase in productivity and more rational production, increase in income, improved quality of products, positive effects on animal welfare, improved working and health conditions, improved storage capacity, high number of created jobs, partial diversification of rural economy, improved competitiveness and increased activity of existing SME. However, it turned out that the farmers inexperienced in demanding public funds had been often discouraged by the volume of information required to accompany an application for projects of any size" (Cerna, 2005).

"SAPARD, as the forerunner of the Structural Funds, has fulfilled a real mission in Hungary with lots of conflicts, mistakes but also with lots of positive impacts. The development resources channelled to agriculture and rural areas, institution building as well as experiences gained on submitting proposals from the clients' point of view and processing, administering, selecting them on the side of the SAPARD Office have to be emphasized" (Kovács et al., 2005).

The rate of SAPS implemented in 2004 was set at EUR 56.4 (CZK 1,830) per hectare in the Czech Republic, EUR 70 (HUF 18,000) in Hungary and EUR 44 (SKK 1,769) in Slovakia. Czech top-up payments were implemented for set-aside arable land and various commodityspecific programmes (hops, suckler cows, ewes and goats, cattle and flax and forage seed). It was limited to 23 per cent. Hungarian CNDPs were provided for area-based support (EUR 32/ha), suckler cows (EUR 159/head), milk (EUR 8/tonnes) and ewes (EUR 6/head). In addition, EUR 44 per hectare of COP crops, grain legumes and seeds, EUR 236 per hectare of rice, EUR 2,960 and EUR 2,320 per hectare of Virginia- and Burley-type tobacco respectively, and EUR 139 per head for fattened bulls were made available after EU accession. CNDPs favoured arable, ruminant and tobacco farmers the most (see e.g. Potori and Nyárs, 2007). In the Slovak Republic top-up payments were implemented through commodity-specific programmes (arable crops, tobacco, hops, suckler cows, sheep and goats). The actual top-up was 27.5 per cent (OECD, 2005).
} 
By now not only Agenda $2000^{8}$, having covered the period 2000-2006 in the 'old' Member States and 2004-2006 in the new MS, but also the previous multiannual financial framework, came to an end. The time has come to start the analysis of the first full financial framework in Slovak Czech and Hungarian history i.e. the period between 2007 and 2013. Furthermore, on 26 June 2013, the European Commission (EC), the European Parliament (EP) and the Council of the EU reached agreement on reforming the CAP) for the period 2014-2020. On 16 December the Council adopted the reform package comprising four main legal texts - regulation establishing rules for direct payments to farmers (1307/2013/EU), regulation on support for rural development (1305/2013/EU), regulation on the financing, management and monitoring of the CAP (1306/2013/ EU), and regulation establishing a common organisation of the markets in agricultural products $(1308 / 2013 / \mathrm{EU})$. A transitional regulation for the year 2014 was also adopted. The rates of direct payments to farmers under the CAP for the period 2014-2020, distribution of these payments, and ultimately their impact on farming decisions, will depend on the combination of mandatory and optional Pillar I support schemes to be introduced in 2015 .

The chapter is aimed at analysing and comparing the direct payments and the CNDP in the period between 2007 and 2013 and the new direct payment systems and their potential impacts in the Czech Republic, Slovakia and Hungary. Detailed objectives are as follows:

- Comparison of the structure of the budgets - aggregate EU and national support - in terms of Direct Payment systems in the period 2007-2013 and in the current financial framework;

- Analysis of the match between the budget's structure and the structure of individual national agriculture. The question arises whether the difference in structures followed differences in the form of agriculture in the three countries?

- Analysis and impact assessment of the new direct payment systems in relation to economic, environmental and social aspects;

- Comparison of the new direct payment systems (common rules - minimum requirements for receiving direct payments, reduction of payments, flexibility between pillars);

- Analysis of the combination of mandatory and optional Pillar I support schemes in the Czech Republic, Slovakia and Hungary. (Introduction of the basic payment scheme [BPS] or further application of SAPS; redistributive payments; small farmers' scheme; voluntary coupled support etc.) Comparison of characteristics of the national allocation mechanisms;

- Analysis and comparison of the impacts induced by different combinations of support schemes: counterfactual analysis;

- Systematisation of possible negative effects originating from the new direct payments system to be faced between 2014 and 2020. Proposals to eliminate them.

According to the working hypothesis, the implementation of the CAP and its impacts were rather similar in the previous multiannual financial framework and those are expected to be similar between 2014 and 2020 in the three countries.

EAGGF Guarantee and Guidance Sections expenditure were as follows:

- in 2004: EUR 168 million in the Czech Republic (0.37 per cent of the total Guarantee Section expenditures) EUR 181.7 million in Hungary ( 0.40 per cent of the total Guarantee Section expenditures), EUR 120.9 million in Slovakia ( 0.27 per cent of the total Guarantee Section expenditures)

- in 2005: EUR 463.8 million in the Czech Republic (0.94 per cent of the total Guarantee Section expenditures) EUR 716.8 million in Hungary (1.46 per cent of the total Guarantee Section expenditures), EUR 247.5 million in Slovakia ( 0.50 per cent of the total Guarantee Section expenditures)

- in 2006: EUR 517.3 million in the Czech Republic (1.03 per cent of the total Guarantee Section expenditures) EUR 826.1 million in Hungary (1.65 per cent of the total Guarantee Section expenditures), EUR 294 million in Slovakia (0.58 per cent of the total Guarantee Section expenditures) (EC DG AGRI, 2010) 


\section{Methodology and Data}

The calculations of direct payment rates and the distribution of these payments was based on data originating from

- the Hungarian Agricultural and Rural Development Agency (ARDA) and the Farm Accountancy Data Network (FADN) in Hungary;

- the Agricultural Paying Agency (APA), Ministry of Agriculture and Rural Development of the Slovak Republic (MPRV SR) and FADN in Slovakia, and

- the State Agricultural Intervention Fund (SZIF), FADN and the National Statistical Office in the Czech Republic (CZSO).

To assess the structural impact of the new policy options to be introduced in the three countries, a model developed in Hungary was used. Each country's input agricultural data were fed into the model, which then yielded simulated results for evaluation of identical scenarios in an agreed result structure. This allowed the researchers to compare and contrast the differences and commonalities of the new policies in the three countries.

The model itself belongs to that group of linear optimisation methods that requires no derivation. This method is often used when there is not enough information regarding the gradient vector when searching for the optimum. The actors of the model are heterogeneous, their decisions are modelled at micro level, and then macro level changes are derived. This way the results of a linear programming model can be interpreted as equilibriums of a well-defined economy/farm. The inputs of the model are divided into three groups: inputs related to FADN (FADN DATABASE), to the support system (SUPPORT), and to independent external sources (HCSO (2014), OECD (2013), PAMI (2013)). Forecasts of the model embrace 15 sectors: crops: wheat, barley, maize, sunflower and rapeseed; livestock: dairy cow, beef cattle (female), beef cattle for fattening (male), ewe, swine for fattening, sow, broiler, duck, turkey and goose (Figure 1).

Figure 1: Schematic flow diagram of the program operation.

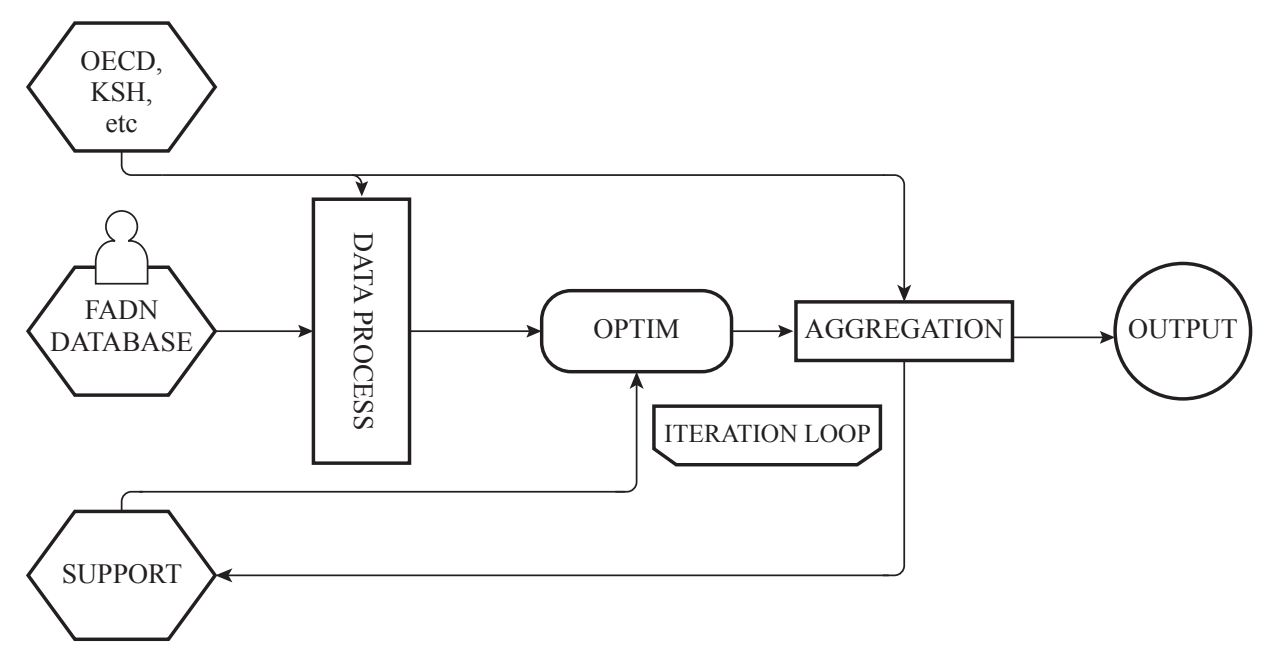

Source: AKI, 2014

A country's economy is modelled using a representative sectoral database of FADN data from a few thousand farms and also external data. The first step is to decide how to allocate the stock of each farm to the different sectors. Individual farms make their decisions based on their own preference systems. They take into account the available costs, revenues and subsidies in the 15 tested sectors. Based on 
these they maximise their profit function and an optimum will be created for each farm by taking into account the relevant legal and natural barriers. Subsequently each optimum rate is normalised then aggregated to derive the changes at the national level during one period. Projections of new periods are predicted and recalculated by the dynamic changes in the cost, revenue and subsidy structure, adjusted according to international predictions provided by OECD and PAMI. In each period a linear discrete optimisation procedure is executed during individual decisions (COBYLA algorithms). The basics of coding and program structure were done using the programming language Python, and the statistical programming language $\mathrm{R}$ was used for the supplementing calculations and costs fittings. (See further description of the model in Vöneki et al., 2015.)

\section{CAP in the period 2007-2013}

Between 2007 and 2013, direct payments represented 71-68 per cent of Heading 2 (agriculture and rural development) and 30-27 per cent of the total EU budget. As regards the decoupled direct aids, they covered 25 per cent of the total budget and about 58-64 per cent of Heading 2 (Table 1).

\section{Table 1: Budgetary expenditure on the Common Agricultural Policy (Commitment appropriations), 2007-2013.}

\begin{tabular}{|c|c|c|c|c|c|c|c|}
\hline Indicator & 2007 & 2008 & 2009 & 2010 & 2011 & 2012 & 2013 \\
\hline EU budget & $120,326.5$ & $131,748.1$ & $131,748.1$ & $139,778.5$ & $139,832.5$ & $141,001.5$ & $147,085.4$ \\
\hline $\begin{array}{l}\text { Policy area: agri- } \\
\text { culture and rural } \\
\text { development }\end{array}$ & $52,026.4$ & $57,905.3$ & $60,054.0$ & $58,880.4$ & $58,578.8$ & $59,514.1$ & $58,851.9$ \\
\hline direct aids & $37,045.8$ & $37,568.6$ & $39,113.9$ & $39,675.7$ & $40,178.0$ & $40,880.0$ & $40,931.9$ \\
\hline $\begin{array}{l}\text { decoupled direct } \\
\text { aids }\end{array}$ & $30,369.1$ & $31,414.5$ & $32,794.1$ & $33,825.0$ & $36,830.4$ & $37,665.5$ & $38,076.0$ \\
\hline
\end{tabular}

Remark: 2007-2012 execution, 2013 budget, year = agricultural year.

Source: EC DG AGRI

Expenditure covered by the European Agricultural Guarantee Fund (EAGF) more than doubled in all three countries between 2007 and 2012, but national expenditure fell by 10 per cent in the Czech Republic, 20 per cent in Hungary and 60 per cent in Slovakia. EAGF subsidies per Utilised agricultural area hectare tripled in Hungary, almost tripled in the Czech Republic and more than doubled in Slovakia over that period of time. EAGF payments per person employed in agriculture increased in all three counties, the rate of growth is however very different. It tripled in Slovakia, more than doubled in the Czech Republic and grew by less than 50 per cent in Hungary due to significant changes in the number of persons employed in agriculture over these years. The EAGF expenditure per output of the agricultural industry doubled in the Czech Republic and Hungary and fell by nearly 20 per cent in Slovakia (Table 2).

Both the annual financial envelope for SAPS and the average annual SAPS payments per eligible area (ha) doubled or more than doubled in all three countries from 2007 to 2012 (Tables 3 and 4). In Slovakia, based on the data reported by the EC DG AGRI source and the APA on direct payments, there are some differences between the budget commitments and disbursed payments to be assessed. The total amount disbursed to SAPS (with the exception of 2012) was lower than its budget (98.8 per cent as an average of 2007-2012). Direct payments in livestock production were reduced only to support suckler cows and heifers, breeding ewes and goats and ewes with a single rate for the whole of Slovakia (2004-2006). From 2007 Slovakia applied payment per livestock unit (LU). Implementation of the budget in 2007-2008 was influenced not only by on-year transfers, but undrawn eligible area for SAPS. In 2007, support of crops represented 81.4 per cent and livestock 18.6 per cent. Cou- 
pled payments represented 41.2 per cent of total amount. In 2013, however, crop support accounted for 96.3 per cent and for livestock only 3.7 per cent. Coupled support fell to 3.7 per cent. The structure of support, however, was influenced by the strict limitations of CAP and measures for coupled support in livestock.

Table 2: EAGF expenditure (commitment appropriations) and national expenditures and EAGF expenditure per UAA hectare, per person employed in agriculture and output of the agricultural industry in the Czech Republic, Slovakia and Hungary, 2007-2012.

\begin{tabular}{|c|c|c|c|c|c|c|c|}
\hline & Indicator & 2007 & 2008 & 2009 & 2010 & 2011 & 2012 \\
\hline \multirow{5}{*}{$\mathrm{CZ}$} & EAGF & 351.6 & 401.7 & 502.7 & 608.6 & 669.3 & 768.9 \\
\hline & EAGF EUR/UAA ha & 82.65 & 113.12 & 141.77 & 171.63 & 192.11 & 220.69 \\
\hline & $\begin{array}{l}\text { EAGF EUR/person employed in } \\
\text { agriculture }\end{array}$ & $1,997.73$ & $2,419.88$ & $3,264.29$ & $4,508.15$ & $4,403.29$ & $4,576.79$ \\
\hline & $\begin{array}{l}\text { EAGF EUR /EUR output of the } \\
\text { agricultural industry }\end{array}$ & 0.08 & 0.08 & 0.14 & 0.15 & 0.14 & 0.16 \\
\hline & national expenditure & 235 & 237 & 219 & 219 & 213 & 207 \\
\hline \multirow{5}{*}{$\mathrm{HU}$} & EAGF & 473.2 & 513.6 & 758 & 955 & $1,053.50$ & $1,144.10$ \\
\hline & EAGF EUR/UAA ha & 81.49 & 88.70 & 131.07 & 165.14 & 224.82 & 244.15 \\
\hline & $\begin{array}{l}\text { EAGF EUR/person employed in } \\
\text { agriculture }\end{array}$ & $2,628.89$ & $2,968.79$ & $4,356.32$ & $4,340.91$ & $3,620.27$ & $3,775.91$ \\
\hline & $\begin{array}{l}\text { EAGF EUR /EUR output of the } \\
\text { agricultural industry }\end{array}$ & 0.07 & 0.07 & 0.13 & 0.15 & 0.14 & 0.15 \\
\hline & national expenditure & 326 & 221 & 224 & 198 & 237 & 255 \\
\hline \multirow{5}{*}{ SK } & EAGF & 157.6 & 165.2 & 220.4 & 274.3 & 297.7 & 332.6 \\
\hline & EAGF EUR/UAA ha & 81.62 & 85.33 & 114.20 & 142.12 & 157.01 & 175.42 \\
\hline & $\begin{array}{l}\text { EAGF EUR/person employed in } \\
\text { agriculture }\end{array}$ & $1,591.92$ & $1,685.71$ & $2,592.94$ & $6,095.56$ & $4,192.96$ & $4,891.18$ \\
\hline & $\begin{array}{l}\text { EAGF EUR /EUR output of the } \\
\text { agricultural industry }\end{array}$ & 0.96 & 0.85 & 1.04 & 1.01 & 0.83 & 0.79 \\
\hline & national expenditure & 34 & 59 & 71 & 57 & 10 & 13 \\
\hline
\end{tabular}

Remark: year $=$ financial year.

Source: EC DG AGRI, 2013

Table 3: Annual financial envelope for SAPS in the Czech Republic, Slovakia and Hungary, 2007-2012.

EUR million

\begin{tabular}{lcccccc}
\hline Country & $\mathbf{2 0 0 7}$ & $\mathbf{2 0 0 8}$ & $\mathbf{2 0 0 9}$ & $\mathbf{2 0 1 0}$ & $\mathbf{2 0 1 1}$ & $\mathbf{2 0 1 2}$ \\
\hline $\begin{array}{l}\text { Czech } \\
\text { Republic }\end{array}$ & 355,384 & 437,762 & 517,895 & 581,177 & 667,365 & 755,659 \\
Hungary & 509,562 & 641,446 & 768,875 & 831,578 & 958,593 & $1,033,364$ \\
\hline Slovakia & 147,342 & 188,923 & 227,613 & 268,304 & 292,357 & 328,485 \\
\hline
\end{tabular}

Remark: year $=$ calendar year.

Source: EC DG AGRI (a) 
Table 4: Average annual SAPS payment per eligible SAPS area in the Czech Republic, Slovakia and Hungary, 2007-2012.

EUR/ha

\begin{tabular}{lcccccc}
\hline \multicolumn{1}{c}{ Country } & $\mathbf{2 0 0 7}$ & $\mathbf{2 0 0 8}$ & $\mathbf{2 0 0 9}$ & $\mathbf{2 0 1 0}$ & $\mathbf{2 0 1 1}$ & $\mathbf{2 0 1 2}$ \\
\hline Czech Republic & 101.40 & 124.61 & 147.43 & 165.08 & 189.33 & 214.28 \\
\hline Hungary & 100.92 & 127.46 & 154.18 & 167.13 & 192.92 & 207.72 \\
\hline Slovakia & 79.09 & 101.20 & 122.32 & 143.76 & 156.47 & 175.16 \\
\hline
\end{tabular}

Source: own calculation based on EC DG AGRI (a)

The amount of direct payments and the amount of decoupled payments doubled in all three countries between financial years 2008 and 2012. The amount of coupled payments changed however significantly over this period. In financial years 2011 and 2012 there was a huge increase in the envelope for coupled payments (Table 5). The number of beneficiaries eligible for direct payments did not change in Slovakia, fell by 10 per cent in Hungary and grew by 20 per cent in the Czech Republic. At the same time the number of beneficiaries eligible for coupled payments hardly changed in Hungary, doubled in Slovakia and more than tripled in the Czech Republic. The average coupled payment per beneficiary was multiplied by 17 in Hungary, 7 in the Czech Republic and only 3 in Slovakia (Table 5).

Table 5: Amount of direct payments and number of beneficiaries for financial years in Hungary, Slovakia and the Czech Republic, 2008-2012.

\begin{tabular}{|c|c|c|c|c|c|c|c|c|}
\hline \multirow{2}{*}{$\begin{array}{l}\text { Finan- } \\
\text { cial year }\end{array}$} & $\begin{array}{l}\text { All direct } \\
\text { payments }\end{array}$ & $\begin{array}{c}\text { No of } \\
\text { beneficiaries }\end{array}$ & $\begin{array}{c}\text { DP/ } \\
\text { Beneficiary }\end{array}$ & $\begin{array}{c}\text { Decoupled } \\
\text { payments }\end{array}$ & $\begin{array}{c}\text { Payment/ } \\
\text { beneficiary }\end{array}$ & $\begin{array}{l}\text { Coupled } \\
\text { payment }\end{array}$ & $\begin{array}{c}\text { No of } \\
\text { beneficiaries }\end{array}$ & $\begin{array}{c}\text { Payment/ } \\
\text { beneficiary }\end{array}$ \\
\hline & $\begin{array}{c}\text { EUR } \\
\text { thousand }\end{array}$ & thousand & EUR & $\begin{array}{c}\text { EUR } \\
\text { thousand }\end{array}$ & EUR & $\begin{array}{c}\text { EUR } \\
\text { thousand }\end{array}$ & thousand & EUR \\
\hline \multicolumn{9}{|c|}{$\mathrm{CZ}$} \\
\hline 2008 & 380,440 & 21.98 & $17,308.46$ & 379,076 & 787.46 & 1,368 & 0.58 & $2,358.62$ \\
\hline 2009 & 473,694 & 23.40 & $20,243.33$ & 472,385 & 865.10 & 1,310 & 0.46 & $2,847.83$ \\
\hline 2010 & 563,477 & 24.61 & $22,896.26$ & 561,722 & 930.36 & 1,754 & 0.49 & $3,579.59$ \\
\hline 2011 & 656,991 & 25.96 & $25,307.82$ & 625,240 & 974.88 & 31,753 & 2.11 & $15,048.82$ \\
\hline 2012 & 743,150 & 26.81 & $27,719.13$ & 711,408 & $1,033.91$ & 31,741 & 2 & $15,870.50$ \\
\hline \multicolumn{9}{|c|}{$\mathrm{HU}$} \\
\hline 2008 & 543,356 & 190.63 & $2,850.32$ & 540,798 & 14.95 & 2556 & 2.7 & 946.67 \\
\hline 2009 & 682,896 & 185.14 & $3,688.54$ & 682,099 & 19.92 & 798 & 1.2 & 665.00 \\
\hline 2010 & 821,206 & 182.83 & $4,491.64$ & 820,388 & 24.57 & 817 & 1.2 & 680.83 \\
\hline 2011 & 953,870 & 178.33 & $5,348.90$ & 908,039 & 29.99 & 45,831 & 2.47 & $18,555.06$ \\
\hline 2012 & $1,078,414$ & 174.61 & $6,176.13$ & $1,032,600$ & 35.37 & 45,813 & 2.84 & $16,131.34$ \\
\hline \multicolumn{9}{|c|}{ SK } \\
\hline 2008 & 156,030 & 15.31 & $10,191.38$ & 154,214 & 665.67 & 1815 & 0.56 & $3,241.07$ \\
\hline 2009 & 200,629 & 15.73 & $12,754.55$ & 197,959 & 810.84 & 2670 & 0.43 & $6,209.30$ \\
\hline 2010 & 245,836 & 15.76 & $15,598.73$ & 243,419 & 989.77 & 2,447 & 0.28 & $8,739.29$ \\
\hline 2011 & 283,056 & 15.85 & $17,858.40$ & 274,296 & $1,126.71$ & 8,764 & 1.41 & $6,215.60$ \\
\hline 2012 & 319,360 & 15.93 & $20,047.71$ & 308,416 & $1,258.49$ & 10,946 & 1.17 & $9,355.56$ \\
\hline
\end{tabular}

Source: EC DG AGRI (b) 
In all three countries, separate decoupled payments were introduced in the sugar and fruits and vegetables (F\&V) sectors, and specific support under Articles 68-72 of Regulation (EC) No. 73/2009 was granted for dairy farmers. In the Czech Republic and Hungary some other sectors were also eligible for specific support (Table 6). Table 6: Overview of the implementation of direct payments in the Czech Republic,
Slovakia and Hungary.

\begin{tabular}{|c|c|c|c|}
\hline & Year & Separate decoupled payments & $\begin{array}{c}\text { Specific support under Articles 68-72 of } \\
\text { Regulation (EC) } N^{\circ} 73 / 2009\end{array}$ \\
\hline \multirow{3}{*}{$\mathrm{CZ}$} & $\begin{array}{l}2007 \text { and } \\
2008\end{array}$ & $\begin{array}{l}\text { separate sugar payment } 85 \text { per cent } \\
\text { separate } F \& V \text { payment } 100 \text { per cent }\end{array}$ & \\
\hline & $\begin{array}{l}2009,2010 \\
2011\end{array}$ & $\begin{array}{l}\text { separate sugar payment } 100 \text { per cent } \\
\text { separate F\&V payment for tomatoes } \\
\text { intended for processing } 100 \text { per cent }\end{array}$ & aid for dairy farmers \\
\hline & 2012 & $\begin{array}{l}\text { separate sugar payment } 100 \text { per cent } \\
\text { separate F\&V payment for tomatoes } \\
\text { intended for processing } 100 \text { per cent }\end{array}$ & $\begin{array}{l}\text { aid for dairy farmers } \\
\text { sheep and goat sector } \\
\text { starch potato sector } \\
\text { improving quality in hops and suckler cow } \\
\text { stocks }\end{array}$ \\
\hline \multirow{3}{*}{ HU } & $\begin{array}{l}2007 \text { and } \\
2008\end{array}$ & $\begin{array}{l}\text { separate sugar payment } 100 \text { per cent } \\
\text { separate F\&V payment } 100 \text { per cent } \\
\text { transitional soft fruit payment } 100 \\
\text { per cent }\end{array}$ & \\
\hline & $\begin{array}{l}2009,2010 \\
2011\end{array}$ & $\begin{array}{l}\text { separate sugar payment } 100 \text { per cent } \\
\text { separate F\&V payment } 100 \text { per cent } \\
\text { transitional soft fruit payment } 100 \\
\text { per cent }\end{array}$ & $\begin{array}{l}\text { in the dairy sector } \\
\text { for tobacco and fresh fruit and vegetable } \\
\text { growing areas, bovine sector and ovine sec- } \\
\text { tor subject to restructuring and development } \\
\text { programmes }\end{array}$ \\
\hline & 2012 & $\begin{array}{l}\text { separate sugar payment } 100 \text { per cent } \\
\text { separate F\&V payment (tomatoes } \\
\text { and other fruits) } 100 \text { per cent }\end{array}$ & $\begin{array}{l}\text { in the dairy sector } \\
\text { for tobacco and fresh fruit and vegetable } \\
\text { growing areas, bovine sector and ovine sec- } \\
\text { tor subject to restructuring and development } \\
\text { programmes } \\
\text { contribution to crop, animal and plant insur- } \\
\text { ance }\end{array}$ \\
\hline \multirow[t]{3}{*}{ SK } & $\begin{array}{l}2007 \text { and } \\
2008\end{array}$ & $\begin{array}{l}\text { separate sugar payment } 100 \text { per cent } \\
\text { separate F\&V payment } 50 \text { per } \\
\text { cent of the envelope for tomatoes } \\
\text { intended for processing and } 100 \text { per } \\
\text { cent of the envelope for fruits other } \\
\text { than annual crops } \\
\text { transitional F\&V payment } 50 \text { per } \\
\text { cent of the envelope for tomatoes } \\
\text { intended for processing }\end{array}$ & \\
\hline & $\begin{array}{l}2009,2010 \\
2011\end{array}$ & $\begin{array}{l}\text { separate sugar payment } 50 \text { per cent } \\
\text { separate } \mathrm{F} \& \mathrm{~V} \text { payment } 67 \text { per cent } \\
\text { separate transitional } \mathrm{F} \& \mathrm{~V} \text { payment } \\
33 \text { per cent of the envelope for toma- } \\
\text { toes intended for processing }\end{array}$ & in the dairy sector \\
\hline & 2012 & $\begin{array}{l}\text { separate sugar payment } 100 \text { per cent } \\
\text { separate F\&V payment } 68 \text { per cent }\end{array}$ & in the dairy sector \\
\hline
\end{tabular}

Source: EC DG AGRI (a) 


\section{CAP in the period 2014-2020}

In the EU-28, 39 per cent of the approximately EUR 960 billion $^{9}$ in appropriations for commitments are available under Heading 2 'Sustainable growth: natural resources' ${ }^{10}$ for the period 20142020. 29 per cent cover market related expenditure and direct payments (Pillar 1) and 9 per cent are available for rural development measures (Pillar 2).

Using constant 2011 prices the amount of Pillar 1 support in 2020 will be 13 per cent less and the amount of Pillar 2 support will be 18 per cent less than the support spent respectively in year 2013 . Commitment appropriations for market-related expenditure and direct payments within the period between 2014 and 2020 amount to EUR 277,851 million and commitment appropriations for rural development reach EUR 84,936 million expressed in constant 2011 prices (EP, 2013) (Table 7).

Table 7: CAP expenditure (EU-28), 2014-2020.

\begin{tabular}{lcccccccccc} 
& & & & & & & & \multicolumn{2}{c}{ EUR million $^{\text {a) }}$} \\
\hline Denomination & $\mathbf{2 0 1 3}$ & $\mathbf{2 0 1 4}$ & $\mathbf{2 0 1 5}$ & $\mathbf{2 0 1 6}$ & $\mathbf{2 0 1 7}$ & $\mathbf{2 0 1 8}$ & $\mathbf{2 0 1 9}$ & $\mathbf{2 0 2 0}$ & $\begin{array}{c}\text { Total: } \\
\mathbf{2 0 1 4} \\
\mathbf{2 0 2 0}\end{array}$ \\
\hline Heading 2 & $\mathbf{5 9 , 6 3 3}$ & $\mathbf{5 5 , 8 8 3}$ & $\mathbf{5 5 , 0 6 0}$ & $\mathbf{5 4 , 2 6 1}$ & $\mathbf{5 3 , 4 4 8}$ & $\mathbf{5 2 , 4 6 6}$ & $\mathbf{5 1 , 5 0 3}$ & $\mathbf{5 0 , 5 5 8}$ & $\mathbf{3 7 3 , 1 7 9}$ \\
\hline $\begin{array}{l}\text { Pillar 1 } \\
\text { of which }\end{array}$ & $\mathbf{4 3 , 1 8 0}$ & $\mathbf{4 1 , 5 8 5}$ & $\mathbf{4 0 , 9 8 9}$ & $\mathbf{4 0 , 4 2 1}$ & $\mathbf{3 9 , 8 3 7}$ & $\mathbf{3 9 , 0 7 9}$ & $\mathbf{3 8 , 3 3 5}$ & $\mathbf{3 7 , 6 0 5}$ & $\mathbf{2 7 7 , 8 5 1}$ \\
\hline direct payment & & & & & & & & & \\
\hline $\begin{array}{l}\text { 30 per cent for } \\
\text { greening }\end{array}$ & & 11,904 & 11,734 & 11,571 & 11,404 & 11,187 & 10,974 & 10,765 & 79,538 \\
\hline \begin{tabular}{l} 
Pillar 2 \\
\hline
\end{tabular} & $\mathbf{1 3 , 8 9 0}$ & $\mathbf{1 2 , 8 6 5}$ & $\mathbf{1 2 , 6 1 3}$ & $\mathbf{1 2 , 3 6 6}$ & $\mathbf{1 2 , 1 2 4}$ & $\mathbf{1 1 , 8 8 7}$ & $\mathbf{1 1 , 6 5 4}$ & $\mathbf{1 1 , 4 2 6}$ & $\mathbf{8 4 , 9 3 6}$ \\
\hline
\end{tabular}

a) In constant 2011 prices.

Source: EP, 2013

In Hungary EUR 10,972 million, in Slovakia EUR 4,062 million and in the Czech Republic EUR 7,434 million (using constant 2011 prices) is available during this multiannual period, out of which direct payments amount to EUR 7,901 million (3 per cent of the EU-28 direct payments), EUR 2,382 million (0.9 per cent) and EUR 5,128 million (2.1 per cent) respectively ${ }^{11}$. Farmers' applications for direct payments might cover EUR 1,269.16 million in current prices in 2020 in Hungary, EUR 394.39 million in Slovakia and EUR 872.81 million in the Czech Republic. Pre-allocations for the three countries are listed in Table 8.

\footnotetext{
9 EUR 959,988 million in appropriations for commitments represents 1.00 per cent of EU Gross National Income (GNI), and EUR 908,400 million in appropriations for payments represents 0.95 per cent of the EU GNI.

10 Commitment appropriations for this Heading, which covers agriculture, rural development, fisheries and a financial instrument for the environment and climate action will not exceed EUR 373,179 million of which EUR 277,851 million will be allocated to market related expenditure and direct payments. (EC, 2013a)

11 EUR 3,071 million (i.e. 3.7 per cent) of the rural development budget in the EU-28 could be spent on rural development measures in Hungary, EUR 1,680 million (i.e. 2.0 per cent) in Slovakia and EUR 2,306 million (i.e. 2.3 per cent) in the Czech Republic.
} 
Table 8: Pre-allocations for the Czech Republic, Hungary and Slovakia (current prices).

EUR million

\begin{tabular}{lccc}
\hline \multicolumn{1}{c}{ Country } & Total 2014-2020 & Total CAP & Direct payments $^{\text {a) }}$ \\
\hline Czech Republic & 30,329 & 8,315 & 6,145 \\
\hline Hungary & 34,335 & 12,390 & 8,935 \\
\hline Slovakia & 18,823 & 4,590 & 2,700 \\
\hline
\end{tabular}

a) 2014: Annex IV to Regulation (EC) No 73/2009 for calendar year 2013 and Annex VIII for HR, RO, BG; 2015: Annex VIII to Regulation (EC) No 73/2009 for calendar year 2014; 2016-2020: Annex III to Regulation (EU) No 1307/2013 calendar years 2015-2019, does not include direct payments for POSEI and Smaller Aegean Islands; subject to financial discipline reduction as referred to in Articles 25-26 of Regulation (EU) No 1306/2013, before flexibility between the Pillars as referred to in Art 136a Regulation (EC) No 73/2009 and Art 14 of Regulation (EU) No 1307/2013; after UK voluntary adjustment for calendar year 2013 as referred to in Art 10(b) of Regulation (EC) No 73/2009; before demining reserve notification for HR for calendar years 2015-2019.

Source: EC, DG Financial Programming and Budget

Within the budget framework the new design of the CAP - with a high degree of flexibility at the supranational level - for the period 2014-2020 will provide options for the EU Member States to increase further the complexity of their existing direct support schemes. In this respect, national governments could rather prefer greater flexibility to facilitating simplification and transparency by a strict selection of optional direct support schemes ${ }^{12}$.

For Hungary ${ }^{13}$, the decision on whether to cap the direct payments for individual farms (reducing the amounts higher than EUR 150 thousand by at least 5 per cent), or rather opting for a redistributive payment (a top-up on the first 30 hectares, amounting to at least 5 per cent of the direct payment ceiling of Hungary and not exceeding 65 per cent of the national average payment per hectare) as from 2015 onwards, was considered by policy decision makers and representatives of farming groups to be of key importance from both political and economic aspects. Determining the exact amount of the subsidy for small farmers within the range of EUR 500-1,250, and defining who can apply for it and how, was of equally high importance (Potori et al., 2013a and 2013b).

It was decided in all three countries to apply the SAPS, to grant the Voluntary Coupled Support (VCS) and the reduction of payments ${ }^{14}$, but not to grant the redistributive payment and the payment for areas with natural constraints from 2014 to 2020. Only Hungary opted for the Small Farmers Scheme. (SFS payments will be rounded up to 500 EUR and the maximum amount is fixed at EUR 1,250. Farmers will not be included automatically.) Basic conditions for SAPS are fulfilling the definition of agricultural activity, an active farmer status and cross-compliance.

As regards the reduction of payments, two tranches of reduction have been decided in Hungary. Between EUR 150 thousand and EUR 176 thousand the payments will be reduced by 5 per cent, above EUR 176 thousand ${ }^{15}$ by 100 per cent. In Slovakia and the Czech Republic, all amounts above EUR 150 thousand will be reduced by 5 per cent. In terms of main policy choices to implement greening the so called equivalent practices ${ }^{16}$ will not be available for farmers in any of these three

\footnotetext{
${ }_{12}$ Rational economic approach at the national or the regional level may justify the implementation of a smaller number of optional support schemes, and favouring the capping of direct payments against a top-up on the first 30 hectares of eligible farm land along the introduction of the subsidy for small farmers.

13 During the negotiations, Hungary put emphasis on convincing other MS and the EC that there was a need to:

- provide the opportunity to increase the percentage of the annual ceiling set out in Annex II (Regulation (EU) 1307/2013) to be granted as Voluntary Coupled Support;

- to offer the possibility to continue SAPS until 2020;

- to increase the maximum SFS payment from EUR 1,000 to EUR 1,250;

- to increase the number of eligible hectares declared by the farmers - 100 hectares was proposed by Hungary.

14 Estimated product of reduction of payments: EUR 69,067 thousand in 2015, EUR 68,999 thousand in 2016, EUR 68,993 thousand in 2017, EUR 68,987 thousand in 2018 and EUR 68,980 thousand in 2019.

15 The limit of EUR 176 thousand (1,200 hectares) is in accordance with the Land Act (coming into force on 1 May 2014) that prescribes that the maximum area of land used by a natural or a legal person normally cannot exceed 1,200 hectares. It has been decided not to apply the subtraction of salaries.

16 Pursuant to Article 43(3) of Regulation (EU) No 1307/2013.
} 
countries, and Ecological Focus Area (EFA) regional and/or collective implementation ${ }^{17}$ and EFA forest exemption are not being applied either ${ }^{18}$ (Table 9).

\section{Table 9: Optional and obligatory direct support schemes in Hungary, Slovakia and the Czech Republic.}

\begin{tabular}{lccc}
\hline \multicolumn{1}{c}{ Schemes } & Czech Republic & Hungary & Slovakia \\
\hline SAPS & yes (2014-2020) & yes (2014-2020) & yes (2014-2020) \\
\hline BPS & not applied & not applied & not applied \\
\hline redistributive payment & not applied & not applied & not applied \\
\hline $\begin{array}{l}\text { payment for areas with } \\
\text { natural constraints }\end{array}$ & not applied & not applied & not applied
\end{tabular}

reduction above EUR 150

reduction of payments thousand: 5 per cent (without possibility of applying deductible items)

\begin{tabular}{|c|c|}
\hline SFS & not applied \\
\hline VCS & $\begin{array}{l}\text { for suckler cows, dairy cows, } \\
\text { sheep, goats, sugar beet, } \\
\text { vegetables fruits, protein } \\
\text { crops, potato starch, hops } \\
\text { and table potatoes. }\end{array}$ \\
\hline flexibility between pillars & $\begin{array}{l}\text { from Direct Payments to } \\
\text { Rural Development: } \\
3.4 \text { per cent per year }\end{array}$ \\
\hline \multicolumn{2}{|l|}{ Greening } \\
\hline equivalent practices & not applied \\
\hline EFA & $\begin{array}{l}\text { land lying fallow; terraces; } \\
\text { landscape features - hedges } \\
\text { or wooded strips, isolated } \\
\text { trees, trees in line, trees in } \\
\text { group and field copses, field } \\
\text { margins, ponds, ditches; } \\
\text { other landscape features } \\
\text { under GAEC or SMR; buffer } \\
\text { strips, hectares of agro- } \\
\text { forestry, strips of eligible } \\
\text { hectares along forest edges; } \\
\text { areas with short rotation cop- } \\
\text { pice; afforested areas; areas } \\
\text { with catch crops or green } \\
\text { cover; areas with nitrogen- } \\
\text { fixing crops }\end{array}$ \\
\hline
\end{tabular}

two tranches of reduction above EUR 150 thousand:

$$
\begin{aligned}
& 5 \text { per cent } \\
& \text { and above }
\end{aligned}
$$

EUR 176 thousand: 100 per cent (without possibility of applying deductible items) rounded up to EUR 500 and maximum amount EUR 1,250 . reduction above EUR 150 thousand: 5 per cent (with possibility of applying deductible items)

not applied ${ }^{\text {a) }}$

for male bovine animals for suckler cow, male bovine (beef), dairy cows, sheep and animals (beef), milk, sheep, goats, sugar beet, some kinds rice, sugar beet, vegetable, of selected vegetable and fruits, protein fodder, soy- fruit species with high and bean and protein crops very high labour demand, and hops.

from Rural Development to from Rural Development to Direct Payments: Direct Payments: 15 per cent/year $18,28 \mathrm{per}$ cent/year

not applied
land lying fallow; terraces; landscape features - hedges or wooded strips, isolated trees, trees in line, trees in group and field copses, field margins, ponds, ditches; other landscape features under GAEC or SMR; buffer strips, hectares of agro-forestry, strips of eligible hectares along forest edges - strips without or with production; areas with short rotation coppice; afforested areas; areas with catch crops or green cover; areas with nitrogen-fixing crops

$$
\text { not applied }
$$

land lying fallow; terraces; landscape features - hedges or wooded strips, isolated trees, trees in line, trees in group and field copses, field margins, ponds, ditches; other landscape features under GAEC or SMR; buffer strips, hectares of agroforestry, strips of eligible hectares along forest edges; areas with short rotation coppice; afforested areas; areas with catch crops or green cover; areas with nitrogenfixing crops.

\footnotetext{
EFA regional and/or collec- no (will be resolved at farm tive implementation level)

EFA forest exemption no 43). By own calculation share for Small farmers represents 0.24 per cent of total RDP expenditures.

Sources: EC (2014) and EC (2015a)

17 In accordance with Article 46(5) and (6) of Regulation (EU) No 1307/2013.

18 In accordance with Article 46(7) of Regulation (EU) No 1307/2013.
} no

no

no

no

a) Small farmers in Slovakia will be supported form Pillar 2 in Rural Development Programme, measure no. 19a) ii (MPRV SR, 2015a, page 
In the framework of greening: all three countries intend to apply the obligation to maintain permanent grassland at national level. The following areas will be considered as EFA: land lying fallow; terraces; landscape features - hedges or wooded strips, isolated trees, trees in line, trees in group and field copses, field margins, ponds, ditches; other landscape features under Good agricultural and environmental condition (GAEC) or Statutory management requirements (SMR); buffer strips, hectares of agro-forestry, strips of eligible hectares along forest edges - strips without production; areas with short rotation coppice; afforested areas; areas with catch crops or green cover; areas with nitrogen-fixing crops.

In the VCS scheme, payment will be available for beef, vegetable and fruit, milk, sheep and goat and sugar beet in all three countries. In the Czech Republic funds will be allocated to hops, protein crops and starch potato. In Slovakia farmers cultivating hops will get additional payments. In Hungary the following sectors will be subsidised: rice and protein crops (Table 10).

Table 10: Voluntary Coupled Support in Hungary.

\begin{tabular}{lccccr}
\hline Indicator & $\begin{array}{c}\text { Percentage of } \\
\text { national ceiling } \\
\text { for each sector/ } \\
\text { product 2015 } \\
\text { (per cent) }\end{array}$ & $\begin{array}{c}\text { Resources } \\
\text { devoted to each } \\
\text { sector/product } \\
\mathbf{2 0 1 5} \\
\text { (EUR million) }\end{array}$ & $\begin{array}{c}\text { Total resources } \\
\text { devoted to } \\
\text { each sector/ } \\
\text { product } \\
\mathbf{2 0 1 5 - 2 0 2 0} \\
\text { (EUR million) }\end{array}$ & $\begin{array}{c}\text { Unit value of } \\
\text { payment for each } \\
\text { sector/product } \\
\text { (EUR/animal, ha) }\end{array}$ & $\begin{array}{c}\text { Estimated } \\
\text { area (ha)/ } \\
\text { number } \\
\text { of } \\
\text { animals }\end{array}$ \\
\hline suckler cow & 20.0 & 35 & 209.68 & 216 & 162,000 \\
\hline beef for fattening & 2.6 & 4.5 & 26.96 & 93.8 & 48,000 \\
\hline dairy cow & 39.5 & 69 & 413.36 & 353.8 & 195,000 \\
\hline ewes & 12.6 & 22 & 131.8 & 24.7 & 890,000 \\
\hline sugar beet & 4.6 & 8 & 47.93 & 421.1 & 19,000 \\
\hline rice & 1.1 & 2 & 11.98 & 689.7 & 2,900 \\
\hline fruits & 9.4 & 16.5 & 98.85 & 660.0 & 25,000 \\
\hline field vegetable & 4.6 & 8 & 47.93 & 400.0 & 20,000 \\
\hline $\begin{array}{l}\text { vegetables for } \\
\text { processing }\end{array}$ & 5.7 & 9.96 & 59.67 & 199.2 & 50,000 \\
\hline $\begin{array}{l}\text { soybean and } \\
\text { protein crops }\end{array}$ & 50.0 & 13.46 & 80.63 & 200.9 & 67,000 \\
\hline protein fodder & 50.0 & 13.46 & 280.63 & 65.0 & 207,000 \\
\hline
\end{tabular}

Source: ISAMM Communication No. 07. 2014/ Feldman, 2015, p. 8-22 
In Slovakia the sectors listed in Table 11 will be subsidised.

Table 11: Voluntary Coupled Support in Slovakia.

\begin{tabular}{lccccr}
\hline Indicator & $\begin{array}{c}\text { Percentage of } \\
\text { national ceiling } \\
\text { for each sector// } \\
\text { product 2015 } \\
\text { (per cent) }\end{array}$ & $\begin{array}{c}\text { Resources } \\
\text { devoted to each } \\
\text { sector/product } \\
\mathbf{2 0 1 5} \\
\text { (EUR million) }\end{array}$ & $\begin{array}{c}\text { Total resources } \\
\text { devoted to } \\
\text { each sector/ } \\
\text { product } \\
\text { 2015-2020 } \\
\text { (EUR million) }\end{array}$ & $\begin{array}{c}\text { Unit value of } \\
\text { payment for each } \\
\text { sector/product } \\
\text { (EUR/animal, ha) }\end{array}$ & $\begin{array}{c}\text { Estimated } \\
\text { area (ha)/ } \\
\text { number } \\
\text { of } \\
\text { animals }\end{array}$ \\
\hline Sugar beet & 1.82 & 7.99 & 48.81 & 393 & 20,320 \\
\hline Hop & 0.02 & 0.09 & 0.52 & 362 & 236 \\
\hline Fruits & 0.26 & 1.14 & 6.97 & 134 & 8,506 \\
\hline Vegetable & 0.13 & 0.57 & 3.48 & 143 & 4,000 \\
\hline Tomatoes & 0.07 & 0.28 & 1.74 & 371 & 767 \\
\hline Sheep and goats & 1.31 & 5.75 & 35.16 & 125 & 45,857 \\
\hline Cattle fattening & 1.80 & 8.11 & 49.56 & 227 & 35,716 \\
\hline Dairy cows & 7.60 & 33.35 & 203.86 & 249 & 134,000 \\
\hline
\end{tabular}

Source: MPRV SR, 2015a; Government Regulation no. 36/2015 Coll.

In the Czech Republic the sectors listed in Table 12 will be subsidised.

Table 12: Voluntary Coupled Support in Czech Republic.

\begin{tabular}{lccccc}
\hline \multicolumn{1}{c}{ Indicator } & $\begin{array}{c}\text { Percentage of } \\
\text { national ceil- } \\
\text { ing for each } \\
\text { sector/product } \\
\mathbf{2 0 1 5} \\
\text { (per cent) }\end{array}$ & $\begin{array}{c}\text { Resources } \\
\text { devoted to } \\
\text { each sector/ } \\
\text { product } \\
\text { 2015 } \\
\text { (EUR million) }\end{array}$ & $\begin{array}{c}\text { Total resourc- } \\
\text { es devoted to } \\
\text { each sector/ } \\
\text { product } \\
\mathbf{2 0 1 5 - 2 0 2 0} \\
\text { (EUR million) }\end{array}$ & $\begin{array}{c}\text { Unit value of } \\
\text { payment for } \\
\text { each sector/ } \\
\text { product } \\
\text { (EUR/animal, } \\
\text { ha) }\end{array}$ & $\begin{array}{c}\text { Estimated } \\
\text { area (ha)/ } \\
\text { number of } \\
\text { animals }\end{array}$ \\
\hline Sugar beet & 13.15 & 16.67 & 116.69 & 267.15 & 62,400 \\
\hline Hop & 2.48 & 3.15 & 22.04 & 593.18 & 5,307 \\
\hline $\begin{array}{l}\text { Fruits with high labour } \\
\text { demand }\end{array}$ & 0.83 & 1.06 & 7.39 & 236.77 & 4,460 \\
\hline $\begin{array}{l}\text { Fruits with very high } \\
\text { labour demand }\end{array}$ & 2.09 & 2.65 & 18.54 & 444.52 & 5,957 \\
\hline $\begin{array}{l}\text { Vegetables with high } \\
\text { labour demand }\end{array}$ & 0.40 & 0.51 & 3.56 & 222.08 & 2,284 \\
\hline $\begin{array}{l}\text { Vegetables with very } \\
\text { high labour demand }\end{array}$ & 2.52 & 3.19 & 22.36 & 370.39 & 8,626 \\
\hline Ware potatoes & 1.46 & 1.85 & 12.96 & 90.34 & 20,481 \\
\hline Potato starch & 2.48 & 3.15 & 22.04 & 719.05 & 4,378 \\
\hline Sheep and goats & 2.24 & 2.84 & 17.35 & 20.37 & 140,199 \\
\hline Suckler calf & 19.21 & 24.35 & 148.49 & 202.92 & 120,000 \\
\hline Dairy cows & 39.78 & 50.42 & 306.29 & 137.04 & 399,518 \\
\hline protein crops & 13.33 & 16.9 & 102.56 & 116.99 & 144,458 \\
\hline Ser & & & & &
\end{tabular}

Source: IAEI 
As regards the Young Farmers Scheme, Slovakia ${ }^{19}$ is expected to allocate about one per cent of the available envelope and both Hungary ${ }^{20}$ and the Czech Republic ${ }^{21}$ are expected to allocate less than one per cent.

As regards flexibility between Pillars, in Hungary 15 per cent of the Rural Development Pillar will be transferred to direct payments starting in the financial year 2016 and in Slovakia 18,276 per cent starting in the financial year 2015. In the Czech Republic, by contrast, about 3.4 per cent of funding is to be transferred from Direct Payments to Rural Development starting in the financial year 2016 (Table 13).

\section{Table 13: Envelope size of Pillar 1 after transfers from and to Pillar 2 in Hungary, Slovakia and the Czech Republic.}

\begin{tabular}{|c|c|c|c|c|c|c|}
\hline Country & 2015 & 2016 & 2017 & 2018 & 2019 & 2020 \\
\hline Czech Republic & & 844.0 & 843.2 & 861.7 & 861.7 & 872.8 \\
\hline Hungary & & $1,345.7$ & $1,344.5$ & $1,343.1$ & $1,343.0$ & $1,342.9$ \\
\hline Slovakia & 437.7 & 441.3 & 445.0 & 449.0 & 453.1 & 445.7 \\
\hline
\end{tabular}

Source: own calculation based on MPRV SR, 2015a and MPRV SR, 2015b

As regards all the optional and obligatory schemes to be applied by the Member States, Table 14 shows the size of schemes expressed in EUR million and their share of the direct payments envelope.

\section{Table 14: Size of schemes and their share of the Direct Payments envelope in Hungary, Slovakia and the Czech Republic in 2015.}

\begin{tabular}{lrrrrrr}
\hline \multirow{2}{*}{ Indicator } & \multicolumn{2}{c}{ CZ } & \multicolumn{2}{c}{ HU } & \multicolumn{2}{c}{ SK } \\
\cline { 2 - 7 } & EUR million & $\begin{array}{c}\text { per cent of } \\
\text { DP envelope } \mathbf{a}^{\text {a) }}\end{array}$ & EUR million & $\begin{array}{c}\text { per cent of } \\
\text { DP envelope }^{\text {a) }}\end{array}$ & EUR million & $\begin{array}{c}\text { per cent of } \\
\text { DP envelope }^{\text {a) }}\end{array}$ \\
\hline SAPS & 456.2 & 53.9 & 724.4 & 48.88 & 244,6 & 55.8 \\
\hline Greening & 253.4 & 30.0 & 403.7 & 30 & 131.7 & 30.0 \\
\hline YFS & 8.4 & 1.0 & 8.3 & 0.62 & 4.4 & 1.0 \\
\hline SFS & - & - & 7.4 & 5.5 & - & - \\
\hline VCS & 126.7 & 15.0 & $174.9+26.9$ & $13+2$ & 5,733 & 13.0 \\
\hline
\end{tabular}

a) Difference to 100 per cent goes to the reserve.

Source: Hungarian Ministry of Agriculture, MPRV SR, Ministry of Agriculture of the Czech Republic (MZe)

\footnotetext{
${ }_{19}$ In the national guidelines is not specified the percentage of payments for young farmers (Guidance of the MPRV SR to Gov. reg. no. $342 / 2014$ Coll.) but based on source MPRV SR (2015a) is possible derives one per cent.

${ }^{20}$ Hungary calculated each year the amount of the payment for young farmers by multiplying a figure corresponding to 25 per cent of the national average payment per hectare by the number of entitlements that the farmer has activated in accordance with Article 32(1), or by the number of eligible hectares that the farmer has declared in accordance with Article 36(2). (Reg. (EU) 1307/2013). According to calculations of the Hungarian Ministry of Agriculture (Czerván, 2015) about 4,000 farmers will be granted this payment with a high degree of certainty, however, potentially about 9,000 farmers are expected to be entitled to this scheme.

${ }_{21}$ Terms are defined in a standard way, as a natural person who first founded the farm and is not older than 40 years. A legal person must meet the following criteria for all individuals having control over a legal person. The payment is for a maximum period of 5 years. The period shall be reduced by the number of years between the founding of the company and the first submission of the application for payment. The number of hectares cultivated by the farmer is not firmly set, but depends on the crop. The idea is that the area must be such that through Standard Output on that crop it must be able to yield the farmer a living income in the Czech Republic (which is currently Standard Output of EUR 10,500 to 14,500 per annum). For greenhouse farming, for example, this can be as little as $600 \mathrm{~m} 2$.
} 


\section{Results of the Model}

The structural impact of the new policy options, i.e. the projected change in livestock number and sowing area are summarised in Table 13 where 2015 is considered to be the base year. Some differences and similarities of the models among the countries analysed are as follows. As for the structure of the model the Slovakian and the Hungarian models are basically the same. They optimise fundamentally by using single farm data of the FADN and search for the best combination of sowing areas and livestock number which is a result of the own preferences of the farmers. In the Hungarian case, broken-line regression is the method to fit cost functions as small and big farms were treated separately. As for the Slovakian data there was no such selection and therefore simple linear regression was used. In the case of the Czech Republic the model had to be adjusted as FADN data for single firms were not available. Certain farm types were identified, and aggregate data were used in the profit-maximising process and in the calculation of profitability. The different farm types were created according to the most typical farming operations. As regards the central algorithm and the flowchart of the program there is, however, no difference between the countries and the external inputs (OECD, PAMI projections) have similar impact on these countries.

\section{Table 15: Projected change in livestock number and sowing area compared to the base year in Hungary, Slovakia and the Czech Republic, 2015-2020.}

\begin{tabular}{|c|c|c|c|c|c|c|c|c|c|c|c|c|}
\hline Year & $\begin{array}{c}\text { Wheat } \\
\text { (ha) }\end{array}$ & $\begin{array}{c}\text { Barley } \\
\text { (ha) }\end{array}$ & $\begin{array}{c}\text { Maize } \\
\text { (ha) }\end{array}$ & $\begin{array}{c}\text { Sun- } \\
\text { flower } \\
\text { (ha) }\end{array}$ & $\begin{array}{c}\text { Rape- } \\
\text { seed } \\
\text { (ha) }\end{array}$ & $\begin{array}{c}\text { Sows } \\
\text { (head) }\end{array}$ & $\begin{array}{c}\text { Pigs } \\
\text { (head) }\end{array}$ & $\begin{array}{c}\text { Chickens } \\
\text { (head) }\end{array}$ & $\begin{array}{c}\text { Dairy } \\
\text { cows } \\
\text { (head) }\end{array}$ & $\begin{array}{c}\text { Suckler- } \\
\text { cows } \\
\text { (head) }\end{array}$ & $\begin{array}{c}\text { Beef } \\
\text { (head) }\end{array}$ & $\begin{array}{l}\text { Ewes } \\
\text { (head) }\end{array}$ \\
\hline \multicolumn{13}{|c|}{ Hungary } \\
\hline 2015 & 100.0 & 100.0 & 100.0 & 100.0 & 100.0 & 100.0 & 100.0 & 100.0 & 100.0 & 100.0 & 100.0 & 100.0 \\
\hline 2016 & 97.8 & 97.6 & 101.7 & 101.9 & 99.9 & 101.7 & 97.8 & 102.1 & 101.4 & 102.4 & 103.0 & 102.8 \\
\hline 2017 & 96.0 & 95.2 & 104.0 & 102.9 & 98.1 & 103.4 & 97.3 & 104.4 & 102.9 & 105.0 & 106.5 & 105.5 \\
\hline 2018 & 94.2 & 92.9 & 105.6 & 104.8 & 96.7 & 104.9 & 103.9 & 106.7 & 104.4 & 107.5 & 110.1 & 108.2 \\
\hline 2019 & 92.4 & 90.6 & 106.8 & 107.1 & 96.2 & 106.3 & 103.1 & 109.0 & 106.0 & 110.2 & 113.9 & 111.1 \\
\hline 2020 & 90.4 & 88.4 & 108.2 & 108.9 & 97.1 & 107.9 & 109.7 & 111.5 & 107.4 & 112.6 & 117.9 & 114.0 \\
\hline \multicolumn{13}{|c|}{ Slovakia } \\
\hline 2015 & 100.0 & 100.0 & 100.0 & 100.0 & 100.0 & 100.0 & 100.0 & 100.0 & 100.0 & 100.0 & 100.0 & 100.0 \\
\hline 2016 & 98.4 & 97.1 & 101.9 & 102.9 & 102.6 & 98.0 & 95.0 & 102.7 & 101.4 & 97.5 & 103.0 & 97.2 \\
\hline 2017 & 96.8 & 94.4 & 103.8 & 105.7 & 105.2 & 96.1 & 90.3 & 105.5 & 102.8 & 95.2 & 106.1 & 94.6 \\
\hline 2018 & 95.1 & 91.6 & 105.5 & 108.8 & 108.0 & 94.1 & 91.6 & 105.2 & 104.2 & 92.8 & 107.7 & 92.0 \\
\hline 2019 & 93.4 & 89.0 & 107.2 & 111.9 & 110.9 & 92.3 & 87.1 & 104.1 & 105.7 & 90.5 & 109.4 & 89.4 \\
\hline 2020 & 91.6 & 86.4 & 108.8 & 115.2 & 113.8 & 90.4 & 82.7 & 103.6 & 107.2 & 88.2 & 111.3 & 87.0 \\
\hline \multicolumn{13}{|c|}{ Czech Republic } \\
\hline 2015 & 100.0 & 100.0 & 100.0 & 100.0 & 100.0 & 100.0 & 100.0 & 100.0 & 100.0 & 100.0 & 100.0 & 100.0 \\
\hline 2016 & 97.0 & 100.6 & 103.0 & 97.0 & 103.0 & 97.3 & 98.0 & 97.3 & 98.6 & 102.5 & 103.0 & 102.8 \\
\hline 2017 & 94.1 & 100.9 & 106.1 & 94.1 & 106.1 & 94.7 & 96.0 & 94.7 & 97.2 & 105.1 & 106.1 & 105.7 \\
\hline 2018 & 91.3 & 100.8 & 109.3 & 91.3 & 109.3 & 92.1 & 94.1 & 92.1 & 95.9 & 107.7 & 109.3 & 108.6 \\
\hline 2019 & 88.5 & 100.3 & 112.6 & 88.5 & 112.6 & 89.6 & 92.2 & 89.6 & 94.5 & 110.4 & 112.6 & 111.7 \\
\hline 2020 & 85.9 & 99.4 & 115.9 & 85.9 & 115.9 & 87.2 & 90.4 & 87.2 & 93.2 & 113.1 & 115.9 & 114.8 \\
\hline
\end{tabular}

Source: own calculations

The model projects the following trends between 2015 and 2020. In all three countries a decrease is expected in the sowing area of wheat and increases are expected in the sowing area of maize and in the livestock number of beef. In Hungary the sowing areas of barley and rapeseed are projected to 
decline and that of sunflower will increase. On the contrary, the sowing area of rapeseed will grow in Slovakia and the Czech Republic (where the growth will be limited by agronomic criteria). The number of sows and pigs will increase in Hungary but decline in the other two countries. The number of other livestock is expected to grow in Hungary. At the same time, in Slovakia the numbers of chickens and dairy cows will increase and the numbers of suckler cows and ewes will fall. In the Czech Republic the numbers of chickens and dairy cows will plummet and the number of ewes will increase (Table 15).

\section{Conclusions}

As regards the absolute amount of expenditures covered by the EAGF (Pillar 1), the annual financial envelope for SAPS, decoupled and coupled payments or the number of beneficiaries of direct payments over the period between the EU accession and now, the data differ significantly among Slovakia, the Czech Republic and Hungary. The Czech and the Slovak data for the EAGF expenditure per person employed in agriculture are rather close to each other, but in terms of EAGF expenditure per utilised arable area the difference between the Czech and Hungarian data is much smaller than the difference between the Czech and the Slovak data or between the Hungarian and the Slovak data. The average annual SAPS payment per eligible SAPS area has been low in Slovakia compared to Hungary or the Czech Republic where the figures have been very close to each other. In certain cases, there are similarities among all three countries, for example, considering some support schemes, separate decoupled payments were introduced in the sugar and F\&V sectors, and specific support under Articles 68-72 of Regulation (EC) No. 73/2009 was granted for dairy farmers.

In the ongoing financial framework all three countries intend to apply SAPS, to grant VCS, and the reduction of payments, but not to grant the redistributive payment and the payment for areas with natural constraints. Only Hungary opted for the SFS. The basic conditions for SAPS will be fulfilling the definition of agricultural activity, an active farmer status and cross-compliance. Greening as an obligatory scheme has very similar requirements in all three countries. As for VCS it is worth having a closer look at each sector because there are not only similar payments per unit of production but also some big differences between the countries. The structural impact of the new policy options, i.e. the projected change in livestock number and sowing area show both similar and different trends depending on the sectors and countries analysed. That is why, all in all, it is advisable to avoid committing the fallacy of sweeping generalisation. 


\title{
Competitiveness of crop production
}

\author{
TIKÁSZ, Ildikó Edit'1 ${ }^{1}$ BENE, Enikő'1, KRÍŽOVÁ, Slávka², NOVOTNÝ, Petr ${ }^{3}$ \\ and JAMBOROVÁ, Mária ${ }^{2}$
}

\section{Introduction}

Crop production serves as the basis of agriculture and determines the competitiveness of many product chains. As regards arable crops cultivated in Hungary, Slovakia and the Czech Republic, the significance of wheat, maize and rapeseed has been similar in the three countries: as on the average of the period 2010-2014 their production values were among the four highest within all cereals and oilseeds together. Besides ensuring self-sufficiency, these crops also play an important role in the agri-food foreign trade of these countries. This chapter presents a comparative analysis of the changes in competitiveness (i.e. production, production value, yields, profitability, consumption and foreign trade) of the main arable sectors in Hungary, Slovakia and the Czech Republic during the period since their accession to the European Union (EU).

The analysis used data available from the national Statistical Offices of the three countries, i.e. the Központi Statisztikai Hivatal (KSH) in Hungary, the Český statistický úřad (ČSÚ) in the Czech Republic and the Štatistický úrad (SR) in Slovakia, from the Farm Accountancy Data Network operated by AKI in Hungary, by ÚZEI in the Czech Republic and by VÚEPP in Slovakia and from Eurostat. The general time frame for the analysis was 2000-2014. For comparison, mainly five-year averages were used; however, in some cases, the available data series allowed only the use of specific individual years.

Of the three countries, cereal production has the greatest significance in Hungary. With a cereals production area of 2.6-3.0 million hectares, representing 59.6-68.2 per cent of the arable land - and an annual production of 8.7-16.8 million tonnes, Hungary was among the top one third of the 28 EU Member States during the period 2000-2014. Both the area and the volume of cereal production represented around 5.0 per cent of the EU average during this period. Cereal production exceeds domestic needs by about twofold, thus cereals represent the bulk of exportable agricultural goods. The main cereal crops in Hungary are maize and wheat, both having relatively stable sowing areas of 1.2 million and 1.1 million hectares respectively. In the Czech Republic, cereals occupied 52.6-60.2 per cent of the arable land during the period 2000-2014. The harvested area of cereals decreased steadily, from 1.7 million hectares in 2000 to 1.4 million hectares in 2014, while the annual production of cereals varied between 6.4 and 8.8 million tonnes. On average, both the area and the production represented around 2.5 per cent of the annual totals for the EU-28 between 2000 and 2014. In Slovakia, cereals accounted for 36.6 per cent of total crop production value in 2000 and 51.7 per cent in 2014, and this trend is expected to continue. In contrast, during this period the production area of cereals decreased from 825.7 thousand hectares as an average of 2000-2004 to 753.6 thousand hectares as an average of 2010-2014. Cereals occupied 51.3-60.4 per cent of the arable land in Slovakia in the period 2000-2014, and around 1.3 per cent of the total EU-28 cereals area.

The area of oilseed crops and its share in the total arable area increased in all the three countries during the period 2000-2014: in Hungary, from 573.3 thousand hectares (12.5 per cent) as an average of the period 2000-2004 to 847.2 thousand hectares (19.6 per cent) in 2010-2014; in Slovakia, from 195.1 thousand hectares (13.9 per cent) to 247.9 thousand hectares (18.1 per cent) and in the Czech Republic, from 408.6 thousand hectares (14.2 per cent) to 475.4 thousand hectares (18.9 per cent). In Hungary, sunflower, with a share of 64.2-74.5 per cent (298.8-615.1 thousand hectares), dominated the total oilseeds area during the period 2000-2014, while rapeseed accounted for 10.8-31.4 per cent

Research Institute of Agricultural Economics, Budapest, Hungary.

National Agricultural and Food Centre - Research Institute of Agricultural and Food Economics, Bratislava, Slovak Republic.

Institute of Agricultural Economics and Information, Prague, Czech Republic. 
(71.0-260.6 thousand hectares). In contrast, the most important oilseed crop in the Czech Republic and in Slovakia was rapeseed, with shares of 59.6-86.0 per cent (251.0-418.8 thousand hectares) and 25.5-66.4 per cent (54.3-167.6 thousand hectares) of the total oilseeds area respectively.

The following subchapters introduce the wheat, grain maize and rapeseed sectors of Hungary, the Czech Republic and Slovakia, and show the impact of the EU's Common Agricultural Policy (CAP) in these sectors by analysing changes before and after the accession to the EU (the periods 2000-2004 and 2010-2014).

\section{Wheat}

Wheat represented 31.1 per cent of the arable land in the Czech Republic, 27.2 per cent in Slovakia and 24.6 per cent in Hungary during the period 2000-2014. During this period the average harvested area was 1,052.4 thousand hectares in Hungary, 835.5 thousand hectares in the Czech Republic and 368.0 thousand hectares in Slovakia. The harvested area of wheat in the Czech Republic declined until the country's accession to the EU, but after that it remained quite stable around an average of 823 hectares during the period 2006-2014. However, the wheat area decreased slowly but steadily in Hungary and in Slovakia. Concerning five year averages, wheat area declined by 6.5 per cent, from 1,125.6 thousand hectares in 2000-2004 to 1052.4 thousand hectares in 2010-2014 in Hungary, and by 4.9 per cent, from 386.9 thousand hectares to 368.0 thousand hectares in the same periods in Slovakia (Table 1).

Table 1: Harvested area and production of wheat in Hungary, the Czech Republic and Slovakia, average of 2000-2004, 2005-2009 and 2010-2014.

\begin{tabular}{lcccc}
\hline \multicolumn{1}{c}{ Country } & Years & $\begin{array}{c}\text { Harvested area } \\
(\mathbf{1 0 0 0} \text { hectares })\end{array}$ & $\begin{array}{c}\text { Hectare yield } \\
\text { (tonnes) }\end{array}$ & $\begin{array}{c}\text { Production } \\
(\mathbf{1 0 0 0} \text { tonnes })\end{array}$ \\
\hline \multirow{3}{*}{ Hungary } & $2000-2004$ & $1,125.6$ & 3.84 & $4,349.4$ \\
& $2005-2009$ & $1,118.6$ & 4.20 & $4,700.2$ \\
\hline \multirow{3}{*}{ Czech Republic } & $2010-2014$ & $1,052.4$ & 4.21 & $4,436.6$ \\
& $2000-2004$ & 850.8 & 4.70 & $4,021.4$ \\
& $2005-2009$ & 809.3 & 5.08 & $4,116.0$ \\
\hline \multirow{3}{*}{ Slovakia } & $2010-2014$ & 835.5 & 5.44 & $4,547.3$ \\
& $2000-2004$ & 386.9 & 3.75 & $1,460.8$ \\
\hline
\end{tabular}

Source: HCSO, CZSO and SO SR

The decline in the harvested area was offset by higher yields in the period 2000-2014, so wheat production increased slightly in each country. Production in the Czech Republic showed the highest growth rate between the averages of the five year periods 2000-2004 and 2010-2014. The wheat output of the Czech Republic rose by 13.1 per cent to 4,547.3 thousand tonnes as an average of the period 2010-2014, but remained below the Hungarian production level, which totalled in 4,436.6 thousand tonnes as an average of the same period, a decrease of 2.0 per cent from the average of 2000-2004. In Slovakia, production increased from 1,460.8 thousand tonnes as an average of 20002004 to 1,569.7 thousand tonnes in 2010-2014 (Table 1). The quality of wheat harvested reflected the annual weather conditions in all the three countries. In years with below average rainfall (e.g. in the marketing year of 2012/2013), the proportion of milling wheat reached 90 per cent in Hungary, 80 per cent in the Czech Republic and 85 per cent in Slovakia. Excessively wet weather (e.g. in the 
marketing year of 2014/2015) caused significant damage in wheat quality, so the proportion of feed wheat increased to 50 per cent in Hungary, to 40 per cent in Czech Republic and to 30 per cent in Slovakia (Tallage, 2015).

In contrast to the harvested area, per hectare wheat yields improved in all the three countries between 2000 and 2014. The biggest increase was in the Czech Republic, where yields grew from 4.70 tonnes/hectare as an average of 2000-2004 to 5.44 tonnes/hectare as an average of 2010-2014. In Hungary, yields increased from 3.84 tonnes/hectare to 4.21 tonnes per hectare, and in Slovakia from 3.75 tonnes/hectare to 4.26 tonnes per hectare in the observed periods (Table 1). However, for the period 2010-2014, wheat yields in all the three countries were far below those (ranging from 7.09 to 7.64 tonnes/hectares) of the main wheat producing EU Member States (France, Germany and the United Kingdom). The annual yield volatility was the highest in Hungary between 2000 and 2014, mainly because extensive wheat production practices are quite frequently applied in the country. Here, tillage is the most important determinant in wheat production, besides soil and climatic conditions (Pepó, 2002).

\section{Production value and farm structure}

Wheat production accounts for not only a large proportion of arable land, but also a big share of the value of crop production in all the three countries. The value of wheat production on average in the period 2010-2014 amounted to EUR 743.4 million in Hungary, EUR 245.6 million in Slovakia and EUR 714.5 million in the Czech Republic in current prices (Table 2). Its share in the value of crop production was 17.2 per cent in Hungary, 26.1 per cent in the Czech Republic and 21.8 per cent in Slovakia. As for the changes between the five year periods of 2000-2004 and 2010-2014, the value of wheat production in the three countries increased by 65.6-77.9 per cent in absolute value, primarily due to the rise in agricultural commodity prices and average yields. At the same time, the proportion of wheat in the value of crop production did not shift substantially in any of the three countries, due to the sharp increases in the shares of oilseed and maize production.

Table 2: Share of crop production (current price) in the value of crop output in Hungary, the Czech Republic and Slovakia, average of 2000-2004 and 2010-2014

\begin{tabular}{lrrrrrr}
\hline \multirow{2}{*}{\multicolumn{1}{c}{ Agricultural products }} & \multicolumn{3}{c}{$\begin{array}{c}\text { Average of 2000-2004 } \\
\text { (EUR million) }\end{array}$} & \multicolumn{3}{c}{$\begin{array}{c}\text { Average of 2010-2014 } \\
\text { (EUR million) }\end{array}$} \\
\cline { 2 - 7 } & \multicolumn{1}{c}{ HU } & \multicolumn{1}{c}{ CZ } & \multicolumn{1}{c}{ SK } & \multicolumn{1}{c}{ HU } & \multicolumn{1}{c}{ CZ } & \multicolumn{1}{c}{ SK } \\
\hline Cereals (including seeds) & $1,244.4$ & 717.2 & 295.1 & $2,166.5$ & $1,209.8$ & 543.5 \\
\hline Wheat and spelt & 449.0 & 409.1 & 138.0 & 743.4 & 714.5 & 245.6 \\
\hline Grain maize & 612.4 & 51.7 & 65.4 & 1153.9 & 137.2 & 194.6 \\
\hline Industrial crops & 405.6 & 361.5 & 122.9 & 848.0 & 711.4 & 257.2 \\
\hline Oilseeds and oleaginous fruits & 269.3 & 208.9 & 75.1 & 771.8 & 547.7 & 210.2 \\
\hline Rape and turnip rape seed & 43.6 & 157.5 & 39.1 & 199.9 & 468.8 & 131.5 \\
\hline Forage plants & 124.6 & 212.3 & 54.7 & 154.1 & 411.5 & 72.4 \\
\hline Vegetables and horticultural products & 589.4 & 99.1 & 90.6 & 565.5 & 204.5 & 157.5 \\
\hline Potatoes (including seeds) & 110.0 & 115.7 & 47.6 & 105.8 & 90.4 & 24.7 \\
\hline Fruits & 358.4 & 54.2 & 40.9 & 355.9 & 47.3 & 44.1 \\
\hline Wine & 36.2 & 20.8 & 0.0 & 94.9 & 34.5 & 0.0 \\
\hline Other crop products & 29.1 & 25.3 & 22.5 & 35.7 & 30.4 & 29.3 \\
\hline Crop output & $2,897.6$ & $1,606.0$ & 674.3 & $4,326.2$ & $2,739.8$ & $1,128.7$ \\
\hline
\end{tabular}

Source: Eurostat 
According to Eurostat Farm Structure Survey (FSS) data, in 2013 there were 67.1 thousand wheat producing farms in Hungary, 12.8 thousand in the Czech Republic and in 10.5 thousand in Slovakia. Between 2005 and 2013 almost 45 per cent of the wheat producing farms in Slovakia (29.7 per cent in the Czech Republic and 16.0 per cent in Hungary) disappeared although the wheat area remained almost stable. For the Czech Republic and Slovakia these changes in the number of farms were in part due to revisions to the FSS methodology in 2010 . However, comparing the 2013 FSS data with those of 2010, the number of wheat producing farms still shows a 7.6 per cent drop in Slovakia in just a few years during which the physical thresholds of the FSS remained unchanged. In the Czech Republic, the number of wheat producing farms increased by 17.4 per cent during the period 2010-2013.

The proportion of small wheat producing farms has been very high in Hungary and in Slovakia. In Hungary, 64.6 per cent, and in Slovakia, 69.2 per cent of the farms produced wheat on less than 5 hectares (small farms), while the same was true only for 36.5 per cent of the farms in the Czech Republic in 2013. During the period 2005-2013, the share of small wheat producing farms in the total number of wheat producing farms declined in all the three countries (by 19.2 percentage points in the Czech Republic, by 15.2 percentage points in Slovakia - both in part due to the changes in physical thresholds - and by 9.1 percentage points in Hungary). Parallel to this, the proportion of farms with over 80 hectares of wheat increased (by 17.2 percentage points in the Czech Republic, 9.5 percentage points in Slovakia and 3.1 percentage points in Hungary). Small farms managed 6.9 per cent of the total wheat area in Hungary, 3.1 per cent in Slovakia and 1.2 per cent in the Czech Republic in 2013. At the same time, the largest proportion of the total wheat area was being used by farms producing wheat on over 80 hectares in each of the countries: 52.6 per cent in Hungary, 83.1 per cent in Slovakia and 83.4 per cent in the Czech Republic (Table 3).

Table 3: Wheat area and the number of wheat producing farms according to physical size category of wheat producing farms in Hungary, the Czech Republic and Slovakia, 2005 and 2013.

\begin{tabular}{|c|c|c|c|c|c|c|c|c|c|}
\hline \multirow[b]{2}{*}{$\begin{array}{c}\text { Farm size } \\
\text { in hectares } \\
\text { of wheat } \\
\text { area }\end{array}$} & \multicolumn{3}{|c|}{ HU } & \multicolumn{3}{|c|}{$\mathbf{C Z}$} & \multicolumn{3}{|c|}{ SK } \\
\hline & 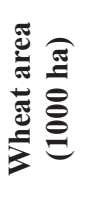 & 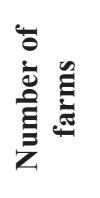 & 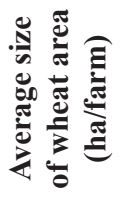 & 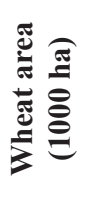 & 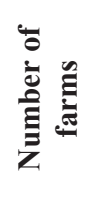 & 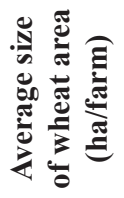 & 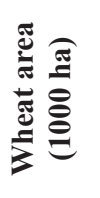 & 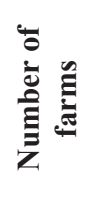 & 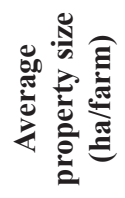 \\
\hline \multicolumn{10}{|c|}{2005} \\
\hline Total & 945.0 & 79,830 & 11.8 & 810.6 & 18,170 & 44.6 & 359.5 & 18,980 & 18.9 \\
\hline$<1$ ha & 10.5 & 27,200 & 0.4 & 1.9 & 4,450 & 0.4 & 4.2 & 11,280 & 0.4 \\
\hline 1-4.9 ha & 64.7 & 31,580 & 4.1 & 12.5 & 5,670 & 4.2 & 8.6 & 4,740 & 4.0 \\
\hline $5-9.9$ ha & 45.8 & 7,800 & 6.6 & 13.5 & 2,030 & 6.7 & 4.9 & 720 & 6.8 \\
\hline 10-79.9 ha & 273.9 & 11,280 & 82.8 & 110.7 & 3,970 & 85.0 & 39.5 & 1,320 & 86.8 \\
\hline$>80$ ha & 544.2 & 1,970 & 276.3 & 672.0 & 2,050 & 327.8 & 302.3 & 930 & 325.0 \\
\hline \multicolumn{10}{|c|}{2013} \\
\hline Total & 938.0 & 67,050 & 14.0 & 833.3 & 12,780 & 65.2 & 356.1 & 10,480 & 34.0 \\
\hline$<1$ ha & 7.4 & 18,170 & 0.4 & 0.4 & 850 & 0.5 & 1.3 & 2,570 & 0.5 \\
\hline 1-4.9 ha & 57.7 & 25,130 & 4.4 & 9.9 & 3,820 & 4.5 & 9.8 & 4,680 & 4.3 \\
\hline $5-9.9$ ha & 60.2 & 8,870 & 6.8 & 13.1 & 1,910 & 6.9 & 5.6 & 820 & 6.8 \\
\hline $10-79.9$ ha & 319.3 & 12,760 & 84.0 & 112.5 & 4,000 & 85.1 & 43.5 & 1,420 & 88.0 \\
\hline$>80$ ha & 493.3 & 2,110 & 233.8 & 697.4 & 2,200 & 317.0 & 295.9 & 1,000 & 295.9 \\
\hline
\end{tabular}

Source: Eurostat 
The dualistic farm structure is also well represented by the average size of the wheat producing area of the farms. Regarding farms with less than 5 hectares of wheat area, this figure was between 1.5-2.2 hectares/farm in the three countries in 2013, and increased by 17.5 per cent in Hungary, 54.8 per cent in the Czech Republic and 91.3 per cent in Slovakia during the period 2005-2013. The average size of the wheat producing area of farms with over 80 hectares of wheat ranged between 234 hectares/farm (in Hungary) and 317 hectares/farm (in the Czech Republic). The average size of large (over 80 hectares) wheat producing farms declined in all the three countries - by 15.4 per cent in Hungary, by 3.3 per cent in the Czech Republic and by 9.0 per cent in Slovakia - during the period 2005-2013 (Table 3).

\section{Economic efficiency}

The profitability of wheat production has been significantly affected by climatic and economic conditions as well as by production practices. The world wheat market, including the European wheat market, has had a considerable impact on domestic wheat markets and wheat prices in Hungary, Slovakia and the Czech Republic since their accession to the EU. During the period 2010-2014, domestic average wheat prices varied between EUR 166 per tonne to EUR 169 per tonne in the three countries, showing much smaller differences compared to the averages of 2001-2004 (i.e. before EU accession), when the Slovakian figure was 36-41 per cent higher ${ }^{4}$, compared to the Czech and the Hungarian ones (Table 4). As crop prices, due to globalisation, became less dependent on local conditions, the competitiveness of different crop producing farms now depends much more on the development of technology to achieve cost-effective production (Evenson, 2002; Kapronczai et al., 2006; OECD, 2011).

Gross margins, calculated over all costs, were in the range EUR 261.5-371.0 per hectare in the three countries as an average of the period 2010-2014. They were the highest in the Czech Republic, 41.9 per cent and 30.3 per cent above the Hungarian and the Slovakian figures, mainly because the average yields were 13.6 per cent and 9.1 per cent higher and - due to much bigger wheat producing area of the farms - other variable costs (e.g. machinery) of the Czech wheat producers were 46.1 per cent and 20.5 per cent lower. Over the same period the proportion of the cost of different inputs in base variable costs was roughly similar in all the three countries. Gross margin was the lowest in Hungary during the period 2010-2014 (Table 4), which can be interpreted by extremely high other variable costs (47.4 and 85.5 per cent above the Czech and the Slovak figures respectively) as a result of fragmented wheat producing areas and the weakening of the Hungarian Forint, especially from 2012 onwards $^{5}$.

In respect to the averages of the periods 2001-2004 and 2010-2014, changes were remarkably moderate in Slovakia, and remained below 50 per cent in each revenue, variable cost and gross margin category. As a consequence, Slovakia lost its leading position in both gross margin categories of wheat production. Although the growth rate of gross margin, calculated over all costs of wheat production, was the largest in Hungary $(+167.9$ per cent), the country's position did not change compared to the other two countries, as its baseline value was the lowest. In contrast, in the Czech Republic, despite the highest increase ( +82.2 per cent) in total variable costs, due to the development of revenue, gross margin, calculated over base costs and all cost also, rose by about 130 per cent, providing the highest profitability of all the countries evaluated (Table 4).

\footnotetext{
4 Above average domestic crop prices in Slovakia were in connection with a small increase in imports in the first wave of agricultural trade liberalisation, as importers did not have enough time to react to tariff cuts as early as in 2002. Additionally, prior to the accession of 2004, agricultural trade was strongly inhibited by a series of non-tariff barriers (Chevassus-Lozza et al., 2005).

5 The EUR to HUF exchange rate increased from an average of HUF 267.6 in 2007-2011 to HUF 298.3 in 2012-2014, while during the same time periods the USD to EUR exchange rate rose from an average of HUF 193.4 to HUF 227.2.
} 
Table 4: Revenue, variable costs and gross margin of wheat in Hungary, the Czech Republic and Slovakia, average of 2001-2004 and 2010-2014

\begin{tabular}{|c|c|c|c|c|c|c|c|c|c|c|}
\hline \multirow{2}{*}{ Denomination } & \multirow{2}{*}{$\begin{array}{c}\text { Unit of } \\
\text { measurement }\end{array}$} & \multicolumn{3}{|c|}{$\begin{array}{l}\text { Average of } \\
\text { 2001-2004 }\end{array}$} & \multicolumn{3}{|c|}{$\begin{array}{l}\text { Average of } \\
2010-2014\end{array}$} & \multicolumn{3}{|c|}{$\begin{array}{l}\text { Change } \\
\text { (per cent) }\end{array}$} \\
\hline & & HU & $\mathbf{C Z}$ & SK & $\mathbf{H U}$ & $\mathbf{C Z}$ & SK & HU & $\mathbf{C Z}$ & SK \\
\hline \multicolumn{11}{|c|}{ Revenue } \\
\hline Price & EUR/tonne & 97.1 & 99.6 & 136.5 & 168.5 & 165.7 & 165.8 & 173.5 & 166.4 & 121.4 \\
\hline Yield & tonnes/hectare & 4.0 & 4.0 & 4.3 & 4.3 & 4.9 & 4.5 & 108.6 & 122.0 & 105.3 \\
\hline Sales revenue & EUR/hectare & 376.1 & 401.4 & 585.1 & 726.0 & 812.1 & 738.1 & 193.0 & 202.3 & 126.1 \\
\hline \multicolumn{11}{|c|}{ Variable costs } \\
\hline $\begin{array}{l}\text { Base variable } \\
\text { costs }\end{array}$ & EUR/hectare & 142.1 & 189.4 & 229.3 & 242.3 & 321.3 & 302.3 & 170.6 & 169.6 & 131.9 \\
\hline Seeds & EUR/hectare & 50.8 & 46.6 & 61.8 & 59.7 & 61.3 & 68.4 & 117.5 & 131.6 & 110.7 \\
\hline Fertilisers & EUR/hectare & 58.6 & 77.1 & 107.0 & 122.2 & 156.7 & 151.6 & 208.5 & 203.2 & 141.7 \\
\hline Crop protection & EUR/hectare & 32.7 & 65.7 & 60.5 & 60.4 & 103.3 & 82.3 & 184.9 & 157.2 & 136.0 \\
\hline $\begin{array}{l}\text { Other variable } \\
\text { costs }\end{array}$ & EUR/hectare & 136.4 & 52.7 & 111.0 & 222.2 & 119.8 & 150.7 & 162.8 & 227.4 & 135.7 \\
\hline $\begin{array}{l}\text { Total variable } \\
\text { costs }\end{array}$ & EUR/hectare & 278.5 & 242.1 & 340.3 & 464.5 & 441.1 & 453.1 & 166.8 & 182.2 & 133.1 \\
\hline $\begin{array}{l}\text { Gross margin } \\
\text { (all costs) }\end{array}$ & EUR/hectare & 97.6 & 159.3 & 244.8 & 261.5 & 371.0 & 284.8 & 267.9 & 232.9 & 116.3 \\
\hline $\begin{array}{l}\text { Gross margin } \\
\text { (base costs) }\end{array}$ & EUR/hectare & 234.0 & 212.0 & 355.9 & 483.7 & 490.8 & 435.5 & 206.7 & 231.6 & 122.4 \\
\hline
\end{tabular}

a)There were no data available for Hungary for the year 2000.

Source: FADN

\section{Utilisation}

The utilisation of wheat differs slightly in the three countries. Within total consumption, the share of wheat used for food production was between 42.0-48.1 per cent in the three countries, as an average of the period 2010/2011-2012/2015. In the Czech Republic, 46.2 per cent of wheat was used in animal feed. Parallel with the decline in livestock numbers, wheat use in animal feed fell in the Czech Republic and Slovakia between the periods 2000/2001-2004/2005 and 2010/20112014/2015, so its share in total consumption shrank by 14.1 percentage points in the Czech Republic and by 12.3 percentage points in Slovakia. In Hungary, the same figure was volatile during the whole period observed, and rose by an average of 2.2 percentage points between 2000/2001-2004/2005 and 2010/2011-2014/2014, because the reduction of the use of wheat in food consumption and for other purposes. The relative stability in the use of wheat in animal feed in Hungary can be also explained by the sharp decrease in the use of grain maize during the same period, due to the changes in the international wheat and maize price ratio and the development of ethanol production. As an average of the period 2010/2011-2010/2014, other uses of wheat (mainly in distilling and the starch industry) were the most common in Slovakia of the three countries; its proportion reached 13.5 per cent (142.8 thousand tonnes) in total consumption, a rise of 2.8 percentage points since the average of the period 2000/2001-2004/2005 (Figure 1). 
Figure 1: Wheat use by segments in Hungary, the Czech Republic and Slovakia, as an average of the period 2000-2004 and 2010-2014.

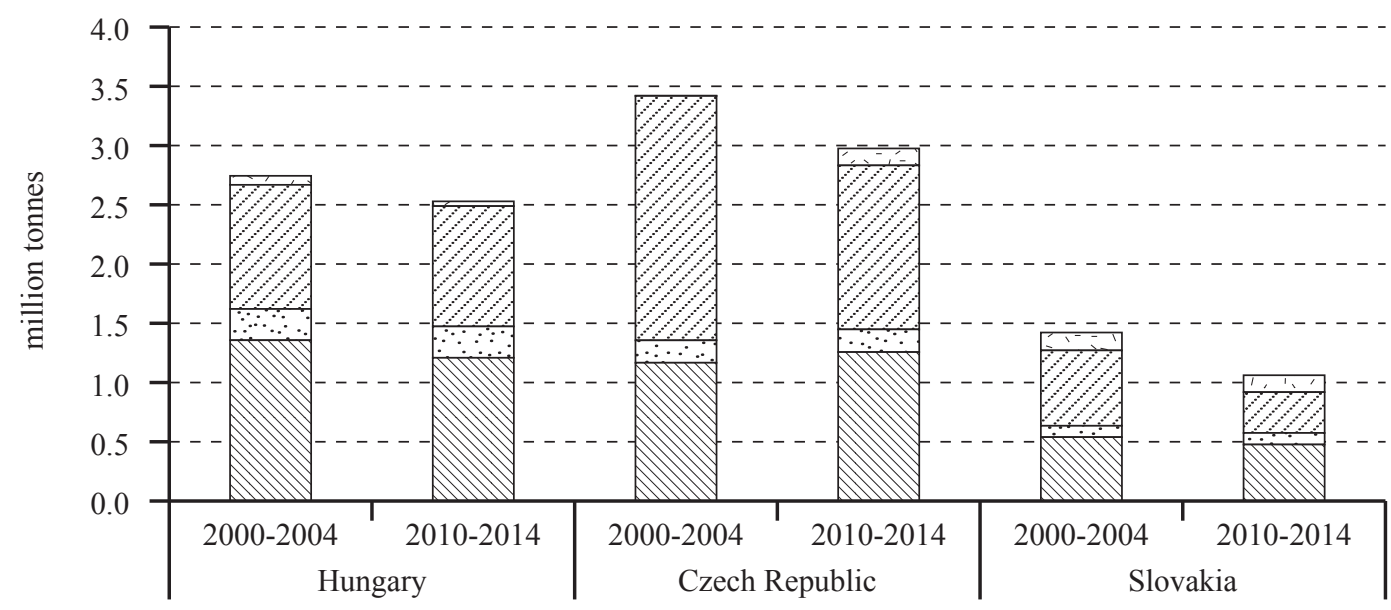

WV Food consumption $\because$ Sowing seed $\quad \square$ Fodder $\quad \cdots$ Other

\begin{tabular}{l|l|l|l|l|l|l|}
$\begin{array}{l}\text { Food } \\
\text { consumption }\end{array}$ & 1.36 & 1.21 & 1.17 & 1.26 & 0.54 & 0.48 \\
\hline Sowing seed & 0.26 & 0.26 & 0.19 & 0.19 & 0.10 & 0.10 \\
\hline Fodder & 1.05 & 1.02 & 2.06 & 1.38 & 0.64 & 0.34 \\
\hline Other & 0.08 & 0.04 & 0.00 & 0.14 & 0.15 & 0.14
\end{tabular}

Source: HCSO, CZSO, MZe, ÚZEI and SO SR

\section{Foreign trade}

As regards the wheat trade balance, Hungary, the Czech Republic and Slovakia are net exporter countries (Hungary: EUR 347.6 million, Czech Republic: EUR 312.8 million, Slovakia: EUR 101.5 million on average in the period 2010-2014). The volume of wheat imports was negligible in each of the three countries during the period 2000/2001-2014/2015, its share of total supply was 1-5 per cent, due to the high rate of self-sufficiency of all the countries (166.9 per cent in Hungary, 136.5 per cent in the Czech Republic and 127.1 per cent in Slovakia). ${ }^{6}$

As an average of the marketing years 2010/2011-2014/2015, Hungary, with 2,024.2 thousand tonnes, was the fifth largest wheat exporter in the EU-28, while the seventh was the Czech Republic, with 1,743.9 thousand tonnes. As for the changes between the periods 2000/2001-2004/2005 and 2010/2011-2014/2015, wheat exports increased the most in Slovakia, to 611.4 thousand tonnes $\left(+1,067.7\right.$ per cent) on average ${ }^{7}$. At the same time the Czech Republic raised its exports to 1743.9 thousand tonnes $(+309.0 \text { per cent })^{8}$ and Hungary to 2,024.2 thousand tonnes ( +46.0 per cent) (Figure 2). Although Hungarian export wheat quality has been characterised by lack of homogeneity (both within and between years), the presence of multinational trading companies (e.g. Cargill, Glencore,

\footnotetext{
6 During the period of the 2000/2001-2004/2005 marketing years, Hungary purchased 23.6 thousand tonnes of wheat on average, which increased to around 221.8 thousand tonnes as an average of the 2010/2011-2014/2015 marketing years. At the same time, the Czech Republic raised its wheat imports to 43.1 thousand tonnes ( +221.0 per cent) and Slovakia to 79.6 thousand tonnes $(+282.4$ per cent $)$ on average (Figure 2).

7 Wheat exports of Slovakia increased besides fluctuating during the period 2000/2001-2014/2015, with selling 783.9 thousand tonnes, record quantity on foreign markets in the crop year 2014/2015 (Figure 2).

8 Wheat exports of the Czech Republic steadily increased besides fluctuating during the period 2000/2001-2014/2015, shipping an all time high volume of 2,6 million tonnes in the crop year 2014/2015 (Figure 2).
} 
etc.), evolved business partnerships in the sector, and quite clear wheat export markets contributed to effective and stable foreign trading opportunities (Varga et al., 2013) ${ }^{9}$.

Figure 2: Foreign trade of wheat in Hungary, the Czech Republic and Slovakia, 2000/2001-2014/2015.

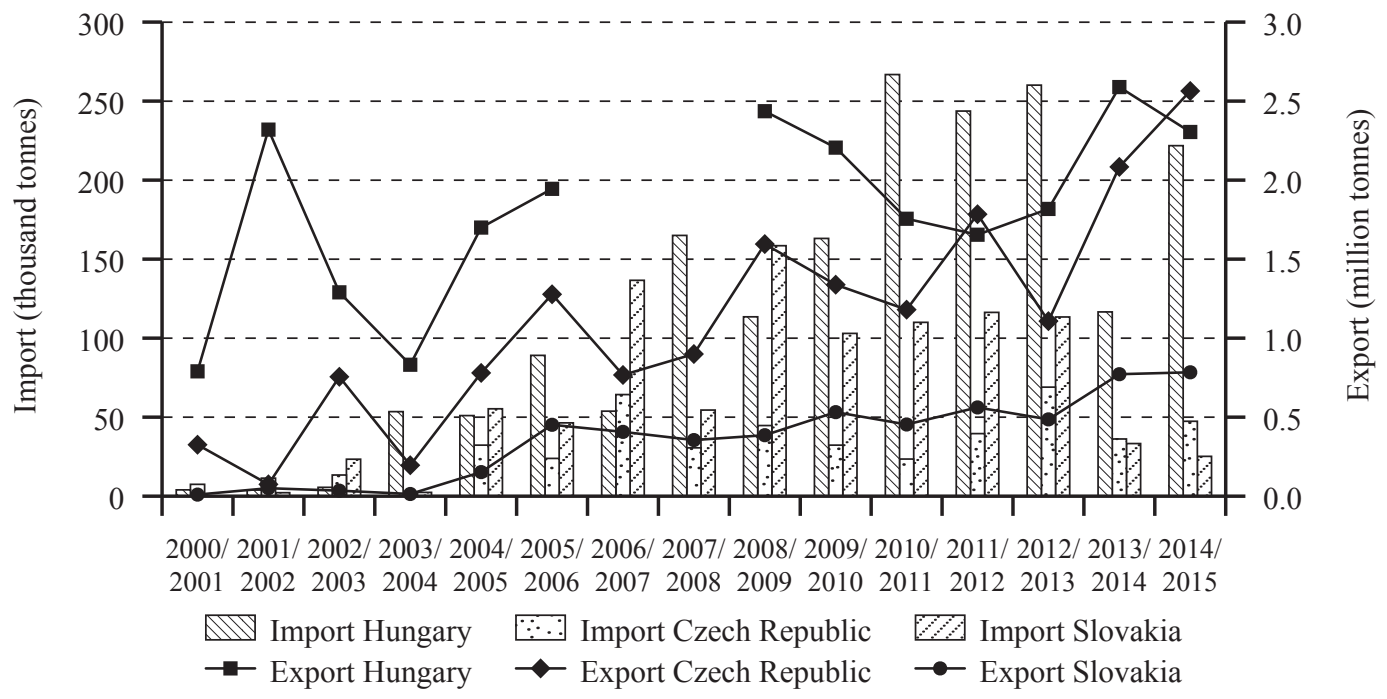

Source: HCSO, CZSO and SO SR

In 2010-2014 the top five export destinations from Hungary in descending order were Italy, Romania, Austria, Bosnia and Herzegovina, and Germany. Hungary exported varying quantities of wheat 1.0-1.9 million tonnes, representing 50-90 per cent of total wheat export - during these years to these countries. Meanwhile, the Czech Republic exported the most of its wheat to Germany, Poland and Austria, and Slovakia to Austria and Poland. Both countries increased their exported quantities in the main destinations year-by-year. Regarding competition in export markets, all the three countries sold very similar quantities of wheat in Austria, but the Czech Republic has remained the most important wheat supplier in Germany since 2008. So in this market only Hungary and Slovakia may compete with each other, due to the increasing volume coming from Slovakia. In Poland's wheat market, Slovakia has taken the first position from the Czech Republic in the rank of supplier countries since 2013, while Hungary exported less than half of their quantity as an average of 2010-2014.

\footnotetext{
9 After the EU accession, Hungarian wheat export quantity, though having been quite volatile, exceeded 1,5 million tonnes each year and reached a record level of 2,8 million tonnes in the marketing year 2006/2007 (Figure 2).
} 


\section{Grain maize}

In contrast to wheat production, the share of maize production in arable crops shows huge differences in the countries analysed. In Hungary, grain maize production has had an outstanding role for decades, its harvested area stabilised between 1.1 and 1.3 million hectares during the period 20042014 (the third largest maize producing area in the EU-28, after Romania and France), and accounted for 26.6 per cent of the total arable land as an average of 2010-2014. In Slovakia, the significance of grain maize production has risen during the ten-year period observed, due to the increased planting area, favourable weather conditions and the use of modern hybrid seeds. The harvested area of grain maize grew from 140.4 thousand hectares as an average of the period 2000-2004 to 203.7 thousand hectares as an average of the years 2010-2014, and represented 12.1 per cent of the total arable land during the period 2010-2014. As a result of the improved production intensity of new maize hybrids, specialised plant protection and modern machinery, maize production spread from the original production area of the Czech Republic to the majority of the country between 2000 and 2014. Although, its harvested area increased the most out of the three countries, by 58.8 per cent between the fiveyear periods of 2000-2004 and 2010-2014, it totalled only a little over 100 thousand hectares as an average of the period 2010-2014. This figure represented 3.5 per cent of the total area of arable land in the Czech Republic, which placed maize production in third place after wheat and barley in the country (Table 5).

Maize production increased in each of the countries between the periods 2000-2004 and 20102014 as a result of larger production areas in Slovakia and in the Czech Republic and of higher yields in all the three countries. The highest rate of increase occurred in Slovakia, the average harvested quantity of maize doubled during the five-year periods analysed, reaching 1,294.7 thousand tonnes as an average of the period 2010-2014. At the same time, in the Czech Republic, maize production rose by 77.9 per cent to 838.4 thousand tonnes, and in Hungary by 12.5 per cent to 7,162.2 thousand tonnes. Thus Hungary was the fourth largest maize producer in the EU-28, representing 10.8 per cent of the EU's total maize production. Despite the growth, maize output can be characterised by high annual volatility in all the three countries, owing rather to variable yields than any change in production area (Table 5).

Table 5: Harvested area and production of grain maize in Hungary, the Czech Republic and Slovakia, average of 2000-2004, 2005-2009 and 2010-2014.

\begin{tabular}{lcccc}
\hline \multicolumn{1}{c}{ Country } & Years & $\begin{array}{c}\text { Harvested area } \\
(\mathbf{1 0 0 0} \text { hectares) }\end{array}$ & $\begin{array}{c}\text { Hectare yield } \\
\text { (tonnes) }\end{array}$ & $\begin{array}{c}\text { Production } \\
\text { (1000 tonnes) }\end{array}$ \\
\hline \multirow{3}{*}{ Hungary } & $2000-2004$ & $1,198.4$ & 5.27 & $6,365.4$ \\
& $2005-2009$ & $1,172.2$ & 6.39 & $7,556.8$ \\
\hline \multirow{3}{*}{ Czech Republic } & $2010-2014$ & $1,186.9$ & 6.05 & $7,162.2$ \\
\cline { 2 - 5 } & $2000-2004$ & 67.9 & 6.69 & 471.3 \\
\hline \multirow{3}{*}{ Slovakia } & $2005-2009$ & 103.7 & 7.34 & 763.2 \\
& $2010-2014$ & 107.8 & 7.74 & 838.4 \\
& $2000-2004$ & 140.4 & 4.68 & 654.8 \\
\hline
\end{tabular}

Source: HCSO, CZSO, SO SR 
Production volatility was the highest in Hungary during the period 2000-2014; harvested maize quantity varied between -51.4 per cent and +120.9 per cent year by year ${ }^{10}$, while in Slovakia it fluctuated to a much more limited extent, between -25.6 per cent and +102.1 per cent, year by year ${ }^{11}$. Maize production was the least volatile in the Czech Republic in this period (between -27.2 and +53.6 per cent year by year) owing to different climatic conditions (less extremities in temperatures during the growing season) $)^{12}$.

As regards per hectare yields, average figures showed increases in all the three countries between the five-year periods of 2000-2004 and 2010-2014. Maize yields rose the most in Slovakia, by 30.8 per cent to an average of 6.12 tonnes/hectare for the period 2010-2014. At the same time, average yields improved only by 15.6 per cent in the Czech Republic, however, yields were the highest here, compared to the other two countries, in both periods: 6.69 tonnes/hectare as an average of the period 2000-2004 c.f. 7.74 tonnes/hectare in 2010-2014. In Hungary, though the use of inputs, especially fertilisers, increased, production practices remained underdeveloped, so the yields of maize production remained below the EU average (7.51 tonnes/hectare) during the whole period of the analysis (Futó és Sárvári, 2015, Marton et al., 2015). Furthermore, as a result of a moderate growth (+14.6 per cent between the five-year periods), Hungarian maize yields totalled 6.05 tonnes/hectare as an average of the years 2010-2014, which was the worst result among the three countries. Comparing all the yield data to the EU average, neither of the three countries could achieve EU average yields as an average of the five-year periods. However, if looking at individual years, sometimes the Czech figure exceeded EU data (e.g. by 15.6 per cent in 2002 or by 7.9 per cent in 2011). In contrast to this, the most effective maize producers in the EU (e.g. Germany, Italy and France) harvested more than 9 tonnes per hectare as an average of 2010-2014.

\section{Production value and farm structure}

Although the value of grain maize production was the highest in Hungary, intensive production growth in the other two countries resulted in more substantial increases in production value during the period 2000-2014. The value of grain maize production in Hungary totalled in EUR 1,154.0 million in current prices during the period 2010-2014, compared to EUR 612.4 million for 2000-2004. This can be mainly attributed to the rise in agricultural commodity prices. Hungary accounted for 9.9 per cent of the value of maize production of the EU-28 as an average of the period 2010-2014. The share of grain maize in the value of crop production increased from an average of 21.1 per cent in 2000-2004 to an average of 26.7 per cent in 2010-2014. In Slovakia, owing to the increase in production, the value of maize production grew more intensively than in Hungary: by 197.7 per cent to EUR 194.6 million in current prices as an average of 2010-2014. Also the share of maize production in the value of crop production increased strongly, from an average of 9.7 per cent in 2000-2004 to an average of 17.2 per cent in 2010-2014. Almost the same trend could be observed, during the five-year periods, in the Czech Republic, where the production value grew by 165.4 per cent to EUR 137.2 million in current prices. However, the proportion of maize production in the value of crop production increased slightly, by 1.8 percentage points to 5.0 per cent as an average of the years $2010-2014$ (Table 2).

\footnotetext{
${ }_{10}$ Production decreased seven times during this ten year period, the most spectacular drops occurred in $2003(-26.0$ per cent $\mathrm{y} / \mathrm{y}), 2007$ (-51.4 per cent $\mathrm{y} / \mathrm{y})$ and $2012(-40.4$ per cent $\mathrm{y} / \mathrm{y})$, driven by extreme hot and dry weather. Total maize output fell below 5 million tonnes in these years. On the other hand, favourable weather conditions resulted in production peaks in 2005, 2008 and 2014, with about 9 million tonnes of maize harvested.

11 The main production losses occurred in 2006 (-21.9 per cent y/y), 2007 (-25.6 per cent y/y) and 2009 (-21.6 per cent y/y), caused by adverse weather conditions. In contrast to this, production reached record levels several times, parallel with the growth of harvested area. The last peak was recorded in 2014 , with a harvested quantity of 1,814.1 thousand tonnes of maize.

12 The harvested quantity of maize, in contrast to Hungary and Slovakia, decreased only five times in the Czech Republic, the most in 2013 (-27.2 per cent $y / y)$, after an all-time high production of 1,063.7 thousand tonnes in 2012. Production losses in 2013 were mainly driven by a drop in harvested area (-18.8 per cent $y / y)$, as areas sown with the so called Bt-maize (GM maize), due to problematic sales, the necessity of separation and obligations of labelling, decreased compared to the previous year by 16.1 per cent to 2.6 thousand hectares, according to the data of the Ministry of Agriculture of the Czech Republic.
} 
Based on FSS data of Eurostat, in 2013 there were 160.9 thousand grain maize producing farms in Hungary, 4.9 thousand in Slovakia and 1.3 thousand in the Czech Republic. During the period 2005-2013, 37.4 per cent of maize producing farms in Hungary, 48.6 per cent in Slovakia and 22.5 per cent in the Czech Republic disappeared, which, in case of Slovakia and the Czech Republic, was in part due to the change in thresholds in the FSS methodology. At the same time, both in Hungary and Slovakia, for farms managing more than 5 hectares of maize, both the number of farms and the maize production area increased in each category. Efficiency problems originating from small farm size have led to a concentration process in maize production sector in Hungary, with a 78.6 per cent increase of average farm size to 6.6 hectares/farm (Béládi and Kertész, 2010). Still, the average maize producing area in Hungary lags far behind that in Slovakia (46.6 hectares/farm) and the Czech Republic (79.6 hectares/farm). In the Czech Republic, only in the category of farms managing more than 50 hectares of maize could similar growth as in Hungary and Slovakia be observed (Table 6).

Table 6: Grain maize area and the number of maize producing farms according to physical size category of maize producing farms in Hungary, the Czech Republic and Slovakia, 2005 and 2013.

\begin{tabular}{|c|c|c|c|c|c|c|c|c|c|}
\hline \multirow[b]{2}{*}{$\begin{array}{c}\text { Farm size } \\
\text { in hectares } \\
\text { of maize } \\
\text { area }\end{array}$} & \multicolumn{3}{|c|}{ HU } & \multicolumn{3}{|c|}{ CZ } & \multicolumn{3}{|c|}{ SK } \\
\hline & 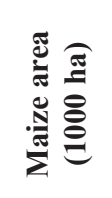 & 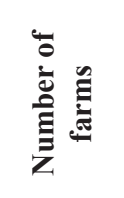 & 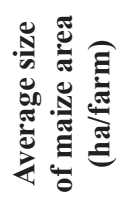 & 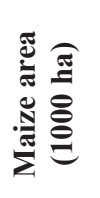 & 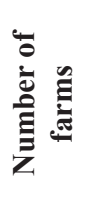 & 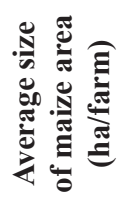 & 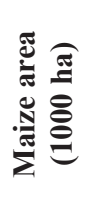 & 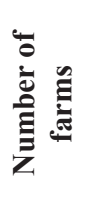 & 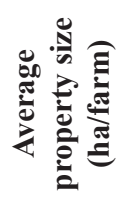 \\
\hline \multicolumn{10}{|c|}{2005} \\
\hline Total & 954.0 & 257,020 & 3.7 & 83.4 & 1,730 & 48.2 & 149.9 & 9,630 & 15.6 \\
\hline$<1$ ha & 46.4 & 173,590 & 0.3 & 0.1 & 290 & 0.2 & 1.5 & 6,720 & 0.2 \\
\hline $1-5$ ha & 113.9 & 59,020 & 1.9 & 0.8 & 350 & 2.4 & 2.7 & 1,360 & 2.0 \\
\hline $5-10$ ha & 69.3 & 10,630 & 6.5 & 1.1 & 160 & 6.9 & 2.2 & 320 & 6.8 \\
\hline $10-50$ ha & 213.8 & 10,850 & 19.7 & 12.2 & 500 & 24.5 & 15.4 & 640 & 24.0 \\
\hline$>50$ ha & 510.6 & 2,930 & 174.3 & 69.1 & 430 & 160.8 & 128.1 & 590 & 217.2 \\
\hline \multicolumn{10}{|c|}{2013} \\
\hline Total & $1,067.2$ & 160,960 & 6.6 & 106.7 & 1,340 & 79.6 & 230.3 & 4,940 & 46.6 \\
\hline$<1$ ha & 23.5 & 89,680 & 0.3 & 0.0 & 60 & 0.5 & 0.5 & 950 & 0.5 \\
\hline $1-5$ ha & 93.4 & 42,350 & 2.2 & 0.7 & 250 & 2.6 & 4.0 & 1,760 & 2.2 \\
\hline $5-10$ ha & 80.2 & 11,720 & 6.8 & 0.8 & 100 & 7.5 & 3.3 & 480 & 6.9 \\
\hline $10-50$ ha & 272.9 & 13,440 & 20.3 & 11.4 & 450 & 25.3 & 20.8 & 870 & 24.0 \\
\hline$>50$ ha & 597.2 & 3,770 & 158.4 & 93.9 & 480 & 195.5 & 201.8 & 890 & 226.7 \\
\hline
\end{tabular}

Source: Eurostat

The dualistic structure of farming appears in maize production - as well as wheat production in Hungary and Slovakia. In Hungary, still 82.0 per cent, and in Slovakia, 54.9 per cent of farms produced maize on less than 5 hectares (small farms) in 2013. The average maize producing area of these farms was 1.3 hectares in both countries. In the same time, only 2.3 per cent of the farms in Hungary, and 18.0 per cent in Slovakia produced maize on more than 50 hectares, but these farms managed 56.0 per cent of the total maize area in Hungary and 87.6 per cent in Slovakia. That means that the average maize producing area of these large farms was 158.4 hectares (2005: 174.3 hectares) in Hungary and 226.7 hectares (2005: 217.2 hectares) in Slovakia in 2013 (Table 6). 
In contrast, in the Czech Republic, only 23.1 per cent (2005: 37.0 per cent) of farms produced maize in less than 5 hectares in 2013, to which belonged 0.6 per cent (2005: 1.1 per cent) of total maize area, 1.0 hectares per farm in average (2005:1.3 hectares/farm). Parallel to this, 35.8 per cent (2005: 24.9 per cent) of maize producing farms managed more than 50 hectares of maize area (196 hectares/farm) one by one, together 87.6 per cent (2005: 85.5 per cent) of total maize area.

\section{Economic efficiency}

The profitability of maize production, due to the favourable development of prices between 20102013, has been quite high in the three countries, especially in Hungary and Slovakia, despite the year by year increases in costs and adverse climate conditions in 2012. However, as regards prices, it should be noted that, as in the case of wheat, the world maize market, as well as the European maize market, strongly influence domestic maize prices in the EU-28 Member States. As a result, the differences in maize prices in Hungary, Slovakia and the Czech Republic were much smaller as an average of the years 2010-2014 (varied between EUR 159 per tonne and EUR 164 per tonne) than before the accession of these countries to the EU in 2004 (ranged between EUR 92 per tonne and EUR 138 per tonne), when again the Slovakian figure exceeded those of the Czech Republic and Hungary by 40-51 per cent (Table 7). Therefore, by evaluating profitability and competitiveness of maize production, emphasis should be put on cost-effectiveness.

Gross margin, calculated over all costs, of maize production varied between EUR 426.2 and EUR 545.3 per hectare in Hungary, Slovakia and the Czech Republic, as an average of the period 20102014. Again, this figure in the Czech Republic exceeded that of Hungary by 27.9 per cent, and Slovakia by 3.1 per cent. This result was in part due to the 4.4-8.1 per cent higher yield compared to Slovakia and Hungary and 25.9 per cent lower other variable cost (e.g. machinery), in contrast to Hungary. Gross margins (both calculated over all costs and base costs) were the lowest in Hungary, owing to low yields (3.4 and 7.5 per cent below the Slovakian and the Czech figures) and high other variable costs (35.0 and 40.8 per cent higher than in the Czech Republic and Slovakia) arising from the small size of the farms and the weakening of the Hungarian Forint from 2012 onwards.

Input costs (base variable costs) of maize production exceeded those of wheat production in all the three countries as an average of the years 2010-2014. The value was again the lowest in Hungary, 19.5 and 26.1 per cent below those of Slovakia and the Czech Republic. However, as in the case of wheat production, within base variable costs, the proportion of the costs of different inputs was very similar in each country: fertilisers represented around 40 per cent, seeds 35 per cent and crop protection 25 per cent. The proportion of seeds in total base variable costs - owing to the cultivation of grain maize hybrids, representing high economic value - was relatively high compared to wheat and rapeseed production (Table 7).

Between the periods 2001-2004 and 2010-2014, due to the moderate changes in the costs and revenue of maize production, compared to Hungary and the Czech Republic, Slovakia lost its leading position in both gross margin categories, and became second after the Czech Republic. Although the value of gross margin almost tripled in Hungary between the periods observed, the country's position weakened to third place, because of its baseline value as an average of 2001-2004 and the extremely high increase in the Czech figures. The growth of variable costs was the highest in the Czech Republic, but this was compensated by the outstanding rise of sales revenue. As a result, the growth rate of Czech maize production's gross margin (calculated over all costs) was twice as high as in Hungary and four times as high as in Slovakia (Table 7). 
Table 7: Revenue, variable costs and gross margin of grain maize in Hungary, the Czech Republic and Slovakia, average of 2001-2004 and 2010-2014.

\begin{tabular}{|c|c|c|c|c|c|c|c|c|c|c|}
\hline \multirow[t]{2}{*}{ Denomination } & \multirow{2}{*}{$\begin{array}{c}\text { Unit of } \\
\text { measure- } \\
\text { ment }\end{array}$} & \multicolumn{3}{|c|}{$\begin{array}{l}\text { Average of } \\
\text { 2001-2004 }\end{array}$} & \multicolumn{3}{|c|}{$\begin{array}{l}\text { Average of } \\
2010-2014\end{array}$} & \multicolumn{3}{|c|}{$\begin{array}{l}\text { Change } \\
\text { (per cent) }\end{array}$} \\
\hline & & HU & $\mathbf{C Z}$ & SK & HU & $\mathbf{C Z}$ & SK & HU & $\mathbf{C Z}$ & SK \\
\hline \multicolumn{11}{|c|}{ Revenue } \\
\hline Price & EUR/tonne & 91.9 & 98.7 & 138.5 & 158.8 & 161.9 & 164.0 & 172.8 & 164.1 & 118.4 \\
\hline Yield & $\begin{array}{l}\text { tonnes/ } \\
\text { hectare }\end{array}$ & 6.0 & 4.5 & 5.7 & 6.7 & 7.2 & 6.9 & 110.7 & 159.3 & 120.7 \\
\hline Sales revenue & EUR/hectare & 533.5 & 444.4 & 793.2 & $1,032.7$ & $1,177.4$ & $1,118.4$ & 193.6 & 265.0 & 141.0 \\
\hline \multicolumn{11}{|c|}{ Variable costs } \\
\hline $\begin{array}{l}\text { Base variable } \\
\text { costs }\end{array}$ & EUR/hectare & 176.3 & 222.5 & 276.4 & 298.7 & 404.1 & 370.9 & 169.4 & 181.6 & 134.2 \\
\hline Seeds & EUR/hectare & 63.6 & 82.9 & 100.1 & 103.9 & 142.4 & 136.4 & 163.4 & 171.8 & 136.3 \\
\hline Fertilisers & EUR/hectare & 60.1 & 80.3 & 101.9 & 119.8 & 180.6 & 152.6 & 199.3 & 224.9 & 149.8 \\
\hline Crop protection & EUR/hectare & 52.6 & 59.4 & 74.4 & 74.9 & 81.2 & 81.9 & 142.4 & 136.7 & 110.0 \\
\hline $\begin{array}{l}\text { Other variable } \\
\text { costs }\end{array}$ & EUR/hectare & 196.4 & 117.1 & 130.5 & 307.8 & 228.0 & 218.6 & 156.7 & 194.7 & 167.5 \\
\hline $\begin{array}{l}\text { Total variable } \\
\text { costs }\end{array}$ & EUR/hectare & 372.7 & 339.6 & 406.9 & 606.5 & 632.1 & 589.5 & 162.7 & 186.1 & 144.9 \\
\hline $\begin{array}{l}\text { Gross margin } \\
\text { (all costs) }\end{array}$ & EUR/hectare & 160.8 & 104.8 & 386.3 & 426.2 & 545.3 & 528.9 & 265.1 & 520.4 & 136.9 \\
\hline $\begin{array}{l}\text { Gross margin } \\
\text { (base costs) }\end{array}$ & EUR/hectare & 357.2 & 221.9 & 516.8 & 734.1 & 773.3 & 747.7 & 205.5 & 348.5 & 144.7 \\
\hline
\end{tabular}

\section{Utilisation}

Maize was mainly used as a feed grain in all the three countries, its share in total consumption was 74.0 per cent in Hungary, 86.3 per cent in the Czech Republic and 45.0 per cent in Slovakia during the period 2000-2014. However, parallel with the downward trend in the number of livestock, the proportion of total maize consumption that was used for feed decreased in each of the countries between the five-year periods of 2000-2004 and 2010-2014: in Hungary from an average of 82.2 per cent to 63.7 per cent, in the Czech Republic from 94.0 per cent to 81.3 per cent and in Slovakia from 59.4 per cent to 33.8 per cent. As a result, in Slovakia, food processing became the most common use of maize, representing 36.2 per cent of total consumption on average for the period 2010-2014 (c.f. 31.4 per cent for the years 2000-2004). Also the proportion of other use - mainly in ethanol production - increased significantly in Slovakia: from an average of 6.5 per cent to 26.2 per cent in the same periods. In Hungary, within maize consumption, the share of maize used in food processing has shown a similar trend as in Slovakia: it grew by 3.4 percentage points to 9.3 per cent between the five-year periods observed. A spectacular development could also be observed in ethanol production, which represented 25.7 per cent of total maize consumption as an average of the years 2010-2014 (10.8 per cent in 2000-2004). In contrast to Slovakia and Hungary, in the Czech Republic, a declining share of maize used as a feed grain in total consumption was exclusively accompanied by a rise in the proportion of ethanol production, from zero to 12.3 per cent regarding the averages of the five-year periods (Figure 3). 
Figure 3: Grain maize consumption by segments in Hungary, the Czech Republic and Slovakia, as an average of 2000-2004 and 2010-2014.

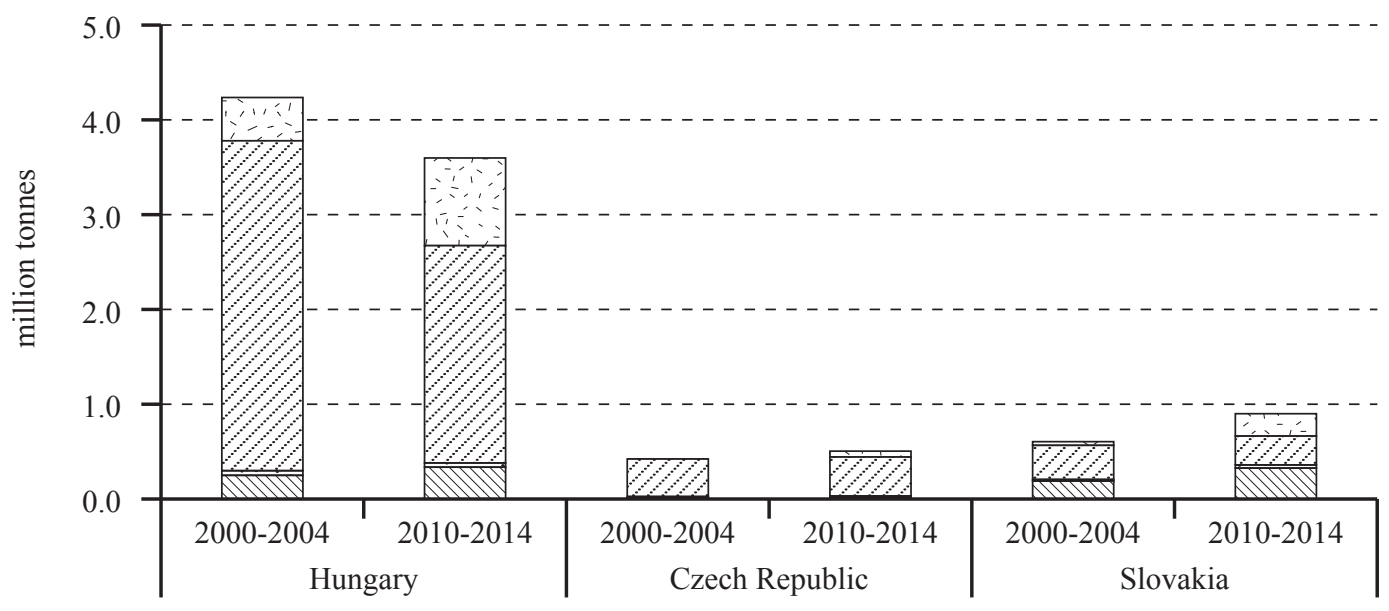

W Food consumption $\because$ Sowing seed $\quad \square$ Fodder $\quad->$ Other

\begin{tabular}{l|l|l|l|l|l|l|l|} 
Food & & 0.013 & 0.016 & 0.190 & 0.326 \\
\hline Sonsumption & 0.250 & 0.336 & 0.013 & 0.016 & 0.034 \\
\hline Fodder & 0.049 & 0.045 & 0.013 & 0.016 & 0.360 & 0.304 \\
\hline Other & 3.480 & 2.292 & 0.396 & 0.411 & 0.039 & 0.236
\end{tabular}

Source: HCSO, CZSO and SO SR

\section{Foreign trade}

Concerning the balance of grain maize trade, all the three countries are net exporters (Hungary: EUR 678.9 million, Czech Republic: EUR 30.7 million, Slovakia: EUR 50.9 million as an average of 2010-2014), however only Hungary has been engaging in significant commercial activity. The volume of maize imports rarely exceeded 200 thousand tonnes during the period 2000/2001-2014/2015 in the three countries. Its proportion of total supply was 2.5 per cent in Hungary, 7.1 per cent in the Czech Republic and 8.0 per cent in Slovakia during the period 2010/2011-2014/2015, due to their high rate of self-sufficiency (199.0 per cent in Hungary, 168.5 per cent in the Czech Republic and 145.6 per cent in Slovakia) (Figure 5). ${ }^{13}$

Hungarian maize exports totalled 3,777.6 thousand tonnes as an average of the marketing years of 2010/2011-2014/2015, which was the second largest volume in the EU-28, after France ${ }^{14}$. Hungary accounted for 19.1 per cent of total EU maize exports. However, from 2013/2014 onward, Romania changed position with Hungary in the second and third places of the EU maize exporters ranking list. Though the Czech Republic and Slovakia were among the top ten maize exporters of the EU, their maize exports reached only 347.6 thousand tonnes and 479.1 thousand tonnes respectively as an average of the period 2010/2011-2014/2015. Maize exports were boosted by the accession to the EU in all the three countries which, at the same time, could be characterised by high volatility, because of

\footnotetext{
13 After the accession to the EU, growing export opportunities to EU markets lead to a general increase in maize imports in all the three countries. Between the five-year periods of 2000/2001-2004/2005 and 2010/2011-2014/2015, Hungary increased its maize imports more than tenfold, to an average of 191.8 thousand tonnes, and the Czech Republic more than seven fold, to an average of 89.6 thousand tonnes. At the same time, Slovakian purchases increased more moderately, by 249.9 per cent to an average of 147.4 thousand tonnes (Figure 4).

${ }^{14}$ It should be emphasised that, within grain maize, Hungary exported 55.8 thousand tonnes of grain maize seed as an average of the period 2010/2011-2014/2015, which was 1.7 per cent of the total exported volume. However, owing to high value added, the value of exported maize seed amounted to EUR 172.6 million, which accounted for 22.8 per cent of the total value of maize exports.
} 
strong dependency on weather influenced production and international prices. Hungary's shipments rose to around 4,000 thousand tonnes as an average of the marketing years of 2005/2006-2014/2015 from 1671.0 thousand tonnes as an average of 2000/2001-2004/2005, due to unrestricted market access, and reached a record level in the marketing year of 2006/2007 with 5,543.6 thousand tonnes. Also the Czech and Slovakian maize exports increased from below 100 thousand tonnes before EU accession to 150-800 thousand tonnes after 2004 in both countries. The Czech Republic sold the largest quantity to its foreign markets, 496.9 thousand tonnes, in the marketing year 2011/2012. Subsequently, in parallel with the decrease in maize production, maize exports declined to around 300 thousand tonnes in the Czech Republic. In Slovakia, maize exports peaked at 788.0 thousand tonnes in the marketing year 2006/2007, then shipments remained between 210 and 600 thousand tonnes per year (Figure 4).

During the period 2010/2011-2014/2015, the top export destinations for Hungarian grain maize were Italy, the Netherlands, Germany, Austria and Romania. These countries accounted for 79.6 per cent of Hungary's total grain maize exports. On average during this five-year period Hungary was the primarily supplier of Italy, Austria and Romania, with market shares of 26.5 per cent, 39.3 per cent and 48.5 per cent respectively in these countries. Hungary's supplier position has been stable in Austria and has improved in Germany, but has declined, because of the increasing imports from Ukraine, in Italy and the Netherlands, and from Bulgaria in Romania. The Czech Republic shipped 69.5 per cent of its total grain maize exports to Germany and Austria as an average of the years 2010/2011-2014/2015. The exported volume was volatile in the case of Germany, changed between 100 and 300 thousand tonnes after 2006/2007, while to Austria an almost steady increase occurred, from a few hundred tonnes in the years 2000/2001-2002/2003 to nearly 150 thousand tonnes in 2014/2015. So, the Czech Republic became the third biggest maize supplier, after Hungary and Slovakia, of Austria in 2009/2010 and its shipments pose a growing threat to Slovakia's position, especially as Slovakia's principal destination for maize has been Austria since 2010/2011. During the period 2010/2011-2014/2015, an average of 36.9 per cent of the Slovakian shipments came to Austria (Figure 4).

Figure 4: Foreign trade of grain maize in Hungary, the Czech Republic and Slovakia, 2000/2001-2013/2014.

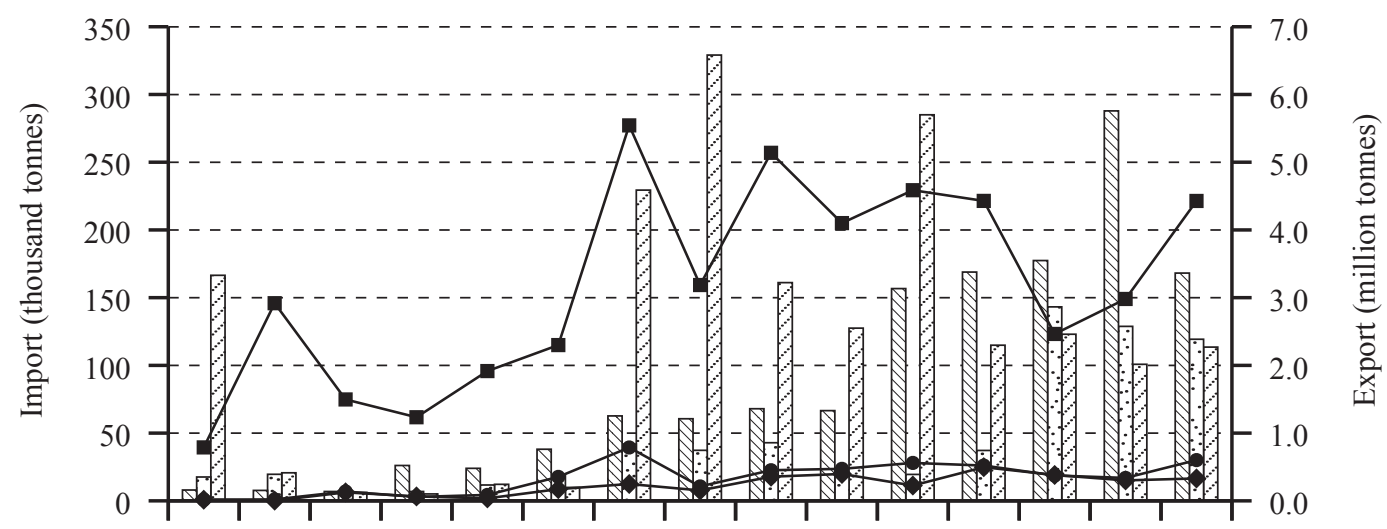

2000/2001/2002/2003/2004/2005/2006/2007/2008/2009/2010/2011/2012/2013/2014/ 200120022003200420052006200720082009201020112012201320142015

MV Import Hungary $\because$ Import Czech Republic $\quad$ Import Slovakia

$\rightarrow$ Export Hungary $\rightarrow$ Export Czech Republic $\rightarrow$ Export Slovakia 


\section{Rapeseed}

The importance of rapeseed production differs in Hungary, the Czech Republic and Slovakia, although the area under this crop - like other major oilseed crops - grew intensively after 2004. This was related to the boom in EU biodiesel production (Potori et al., 2014). In the Czech Republic the crop accounted for 390.3 thousand hectares - the fifth largest area in the EU-28 - and represented 15.5 per cent in arable land as an average of the period 2010-2014. In Slovakia the rapeseed area totalled 135.3 thousand hectares and its share of arable land was 9.9 per cent. Despite being the most dynamically developing sector in field crop production, the proportion of rapeseed area in arable land was only 4.4 per cent in Hungary, with an area of 213.9 thousand hectares (Table 8).

The harvested area of rapeseed in Hungary increased from around 70-120 thousand hectares during the period 2000-2005 to 240-260 thousand hectares in the period 2007-2011. Adverse weather conditions - severe frost damage caused significant crop losses in early 2012 and serious drought during planting decreased the harvested area in 2013 (Ecsediné Wanek et al., 2013, 2014) - lead to a drop in the harvested area of rapeseed in Hungary to below 200 thousand hectares. The same trend occurred in Slovakia, where the harvested area of rapeseed increased to 150-166 thousand hectares during the period 2007-2011, compared to 50-120 thousand hectares between 2000-2005 and dropped below 150 thousand hectares in 2012 and in 2013. In contrast, the harvested area of rapeseed in the Czech Republic increased year-by-year from 2004 onward, and exceeded 400 thousand hectares in 2013.

Rapeseed production trends showed similarities in Hungary and Slovakia during the period 20102014: reaching their lowest levels, 108.1 thousand tonnes in Hungary and 53.0 thousand tonnes in Slovakia, in 2003, mostly due to the decrease in harvested area and reduced yields as a result of frost damage. After EU accession, rapeseed production increased year-by-year in both countries, peaking in 2008 at 654.7 thousand tonnes in Hungary and 424.4 thousand tonnes in Slovakia. Following four years of decline - mainly as a result of unfavourable weather condition and lower yields - rapeseed production reached record quantities, i.e. 699.8 thousand tonnes in Hungary and 448.9 thousand tonnes in Slovakia, in 2014. In the Czech Republic, rapeseed production was a little more volatile during the period 2000-2014. In 2013, as in Hungary and Slovakia, production fell from 700-1,000 thousand tonnes in the years before to a multi-year low of 387.8 thousand tonnes. After returning to a level of around 1,000 thousand tonnes between 2006 and 2012, rapeseed production - driven by above average yields (3.45 tonnes/hectare) - rose sharply to 1,443.2 thousand tonnes in 2013 and to $1,537.3$ thousand tonnes in 2014.

Table 8: Harvested area and production of rapeseed in Hungary, the Czech Republic and Slovakia, average of 2000-2004, 2005-2009 and 2010-2014.

\begin{tabular}{lcccc}
\hline \multicolumn{1}{c}{ Country } & Years & $\begin{array}{c}\text { Harvested area } \\
(\mathbf{1 0 0 0} \text { hectares })\end{array}$ & $\begin{array}{c}\text { Hectare yield } \\
\text { (tonnes) }\end{array}$ & $\begin{array}{c}\text { Production } \\
\text { (1000 tonnes) }\end{array}$ \\
\hline \multirow{3}{*}{ Hungary } & $2000-2004$ & 106.2 & 1.86 & 198.2 \\
& $2005-2009$ & 199.4 & 2.35 & 470.2 \\
\hline \multirow{3}{*}{ Czech Republic } & $2010-2014$ & 213.9 & 2.55 & 541.2 \\
& $2000-2004$ & 298.1 & 2.57 & 770.0 \\
\hline \multirow{3}{*}{ Slovakia } & $2005-2009$ & 321.7 & 3.01 & 971.7 \\
& $2010-2014$ & 390.3 & 3.16 & $1,235.6$ \\
\hline & $2000-2004$ & 93.1 & 1.94 & 189.5 \\
\hline
\end{tabular}

Source: HCSO, CZSO and SO SR 
As a consequence of the spread of hybrid oilseed rape plants - since high production potentials, stable and consistent yields - and modern production practices, yields increased in Hungary during the period 2000-2014 (Pepó, 2012), and the same holds true for the Czech Republic and Slovakia, as well as the average of the EU-28. Yields increased the most in Hungary, by 37.6 per cent from 1.86 tonnes/hectare as an average of the years 2000-2004 to an average of 2.55 tonnes/hectare for the period 2010-2014. At the same time, in Slovakia, oilseed rape yields increased from 1.94 tonnes/ hectare to 2.52 tonnes/hectare. Although the rate of the change in yields was the lowest $(+22.7$ per cent) in the Czech Republic, average yields were the highest in this country, in both time series: 2.57 tonnes/hectare during the period 2000-2004 and 3.16 tonnes/hectare between 2010-2014 (Table 8). However, this latter was only the tenth highest yield in the EU-28, and was 16.7 per cent lower than the yield of Germany, the leading rapeseed producer in the EU.

\section{Production value and farm structure}

Oilseeds - as mentioned in the beginning of the chapter - represent significantly smaller proportion in the total value of crop production than cereals. The value of rapeseed production was the highest in the Czech Republic out of the three countries, and totalled EUR 468.8 million in current prices (7.2 per cent of the value of rapeseed production of the EU-28) as an average of the period 2010-2014. Meanwhile, the share of rapeseed in the value of crop production was 17.1 per cent, and showed a very intensive growth compared to the five-year period 2000-2004, when it was 9.8 per cent. Almost the same holds true for Slovakia, where the value of rapeseed production rose by 236.3 per cent to an average of EUR 131.5 million in current prices, during the five year periods examined. Its share in crop production increased also quite intensively, from an average of 5.8 per cent of the period 2000-2004 to an average of 11.6 per cent in the years 2010-2014. In Hungary, the value of rapeseed production averaged EUR 199.9 million between 2010 and 2014 in current prices, and showed the highest growth (+358.9 per cent) compared to the period 2000-2004 of the three countries. However, because cereals account for 50.1 per cent of the value of crop production and of the strong commitment to sunflower seed production, oilseed rape could reach only a share of 4.6 per cent of production during the period 2010-2014 (2000-2004: 1.5 per cent). The increase of the value of rapeseed production in all the three countries can be explained, besides the rise in commodity prices, by expanding production area and improving yields, in particular after 2004 (Table 2).

Growing prosperity of biodiesel production in the EU interprets the spread of rapeseed production in Hungary, the Czech Republic and Slovakia. The raw material requirement of the biodiesel industry ensures a quite stable market demand for rapeseed compared to other crops (Béládi and Kertész, 2013). This lead to a visible increase in the number of rapeseed producing farms in these countries during the period 2005-2013, according to FSS data. In spite of the declining trend in the number of agricultural farms, in part due to the changes in the FSS thresholds, during the period 2005-2013 the number of rapeseed producing farms increased one and a half times in Hungary, to 6,960, by 32.4 per cent in the Czech Republic, to 4,820 and by 23.8 per cent in Slovakia, to 1,610 (Table 9). However, comparing the 2013 FSS data with those of 2010, rapeseed producing farm numbers declined by 21.1 per cent in Hungary and by 17.0 per cent in Slovakia. In contrast, in the Czech Republic, this figure increased by 10.3 per cent.

Oilseed rape has been mainly produced on larger farms in Slovakia and the Czech Republic; the average rapeseed area was 85.8 hectares/farm and 86.4 hectares/farm respectively in these two countries in 2013. In Slovakia, 51.6 per cent, and in the Czech Republic 41.3 per cent of rapeseed producing farms cultivated over 50 hectares of the crop in 2013. At the same time, the share of farms producing rapeseed on less than 5 hectares in the total number of rapeseed producing farms was only 9.3 per cent in the Czech Republic and 19.9 per cent in Slovakia. By contrast, the number of rapeseed producing farms was much more balanced between the different farm size categories in Hungary. 
Only 23.4 per cent of the farms produced the crop on more than 50 hectares. Consequently, the average rapeseed area was 28.7 hectares in Hungary in 2013. During the period 2005-2013, the share of small rapeseed producing farms among all rapeseed producing farms increased in Hungary $(+9.3$ percentage points) and in Slovakia (+9.1 percentage points), but decreased in the Czech Republic (-1.9 percentage points). In parallel, the proportion of farms growing more than 50 hectares of rapeseed declined in each of the countries (by 6.2 percentage points in Hungary, 3.8 percentage points in the Czech Republic and 6.1 percentage points in Slovakia). Small farms managed 1.9 per cent of the total rapeseed area in Hungary, 0.3 per cent in the Czech Republic and 0.5 per cent in Slovakia in 2013. However, over 75 per cent of the total rapeseed area was being used by farms producing more than 50 hectares of the crop in each of the countries (Table 9).

Table 9: Rapeseed area and the number of rapeseed producing farms by different rapeseed producing farm sizes in Hungary, the Czech Republic and Slovakia, 2005 and 2013.

\begin{tabular}{|c|c|c|c|c|c|c|c|c|c|}
\hline \multirow[b]{2}{*}{$\begin{array}{c}\text { Farm size } \\
\text { in hectares } \\
\text { of rape- } \\
\text { seed area }\end{array}$} & \multicolumn{3}{|c|}{ HU } & \multicolumn{3}{|c|}{$\mathrm{CZ}$} & \multicolumn{3}{|c|}{ SK } \\
\hline & 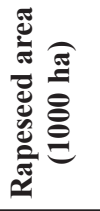 & 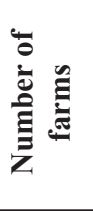 & 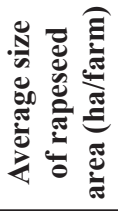 & 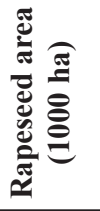 & 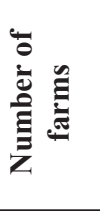 & 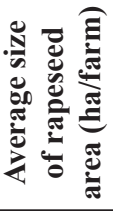 & 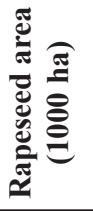 & 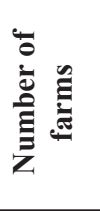 & 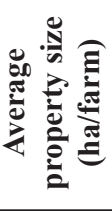 \\
\hline \multicolumn{10}{|c|}{2005} \\
\hline Total & 105.3 & 2,810 & 37.5 & 265.0 & 3,650 & 72.6 & 108.0 & 1,300 & 83.1 \\
\hline$<1$ ha & 0.0 & 50 & 0.4 & 0.0 & 90 & 0.2 & 0.0 & 40 & 0.5 \\
\hline $1-5 \mathrm{ha}$ & 1.1 & 470 & 2.3 & 0.9 & 320 & 2.9 & 0.3 & 100 & 2.5 \\
\hline $5-10$ ha & 2.0 & 390 & 5.2 & 2.9 & 430 & 6.8 & 0.8 & 110 & 6.8 \\
\hline $10-50$ ha & 16.6 & 1,070 & 15.5 & 24.1 & 1,170 & 20.6 & 6.6 & 300 & 22.0 \\
\hline$>50 \mathrm{ha}$ & 85.6 & 830 & 103.1 & 237.1 & 1,640 & 144.5 & 100.4 & 750 & 133.8 \\
\hline \multicolumn{10}{|c|}{2013} \\
\hline Total & 200.1 & 6,960 & 28.7 & 416.4 & 4,820 & 86.4 & 138.2 & 1,610 & 85.8 \\
\hline$<1$ ha & 0.2 & 430 & 0.5 & 0.0 & 0.0 & 0.0 & 0.0 & 40 & 0.5 \\
\hline $1-5$ ha & 3.6 & 1,510 & 2.4 & 1.3 & 450 & 2.9 & 0.7 & 280 & 2.6 \\
\hline 5-10 ha & 5.5 & 920 & 5.9 & 3.6 & 510 & 7.1 & 0.8 & 120 & 6.6 \\
\hline $10-50$ ha & 37.6 & 2,470 & 15.2 & 41.8 & 1,870 & 22.3 & 7.1 & 340 & 20.8 \\
\hline$>50$ ha & 153.2 & 1,630 & 94.0 & 369.7 & 1,990 & 185.8 & 129.6 & 830 & 156.1 \\
\hline
\end{tabular}

Source: Eurostat 


\section{Economic efficiency}

The evaluation of the economic efficiency of rapeseed production confirms that - similar to wheat and maize production - climatic conditions and economic environment, as well as the level of production practices determine the profitability of rapeseed production to a considerable extent. Domestic rapeseed prices in Hungary, the Czech Republic and Slovakia have followed the trend of world oilseed and vegetable oil prices or mainly the European price tendency of rapeseed and rapeseed oil, since these countries joined the EU in 2004. As with wheat and maize production, when comparing the domestic prices of rapeseed, less differences can be detected between the countries in the average of the period 2010-2014 (prices varied between EUR 376 and EUR 403 per tonne) than in the average of the period 2001-2004 (prices changed between EUR 200 and EUR 270 per tonne), when the domestic price of Slovakia proved to be outstandingly high again (Table 10). That is the reason why cost-effectiveness is examined primarily in connection with the competitiveness of rapeseed production.

Gross margin, calculated over all costs, of rapeseed production ranged between EUR 408.4 and EUR 606.8 per hectare in the three countries, as an average of the period 2010-2014. As with wheat and grain maize production, the Czech Republic's gross margin (all costs) was 39.0 and 48.6 per cent above the figures for Slovakia and Hungary. This was due to 13.8-28.3 per cent higher rapeseed yields and 12.5-41.2 per cent lower other costs (e.g. machinery) in the Czech Republic, compared to Slovakia and Hungary, as an average of the period evaluated. Meanwhile, Hungary realised the lowest gross margin (calculated over all costs), and this can be explained in part by the 8.0-21.0 per cent lower rapeseed yields compared to Slovakia and the Czech Republic, by extremely high other variable costs (48.9 and 70.2 per cent above the Slovakian and the Czech figures), again as a result of the small average size of the rapeseed producing area and the weakening of the Hungarian Forint after 2012 (Table 10).

Table 10: Revenue, variable costs and gross margin of rapeseed in Hungary, the Czech Republic and Slovakia, average of 2001-2004 and 2010-2014.

\begin{tabular}{|c|c|c|c|c|c|c|c|c|c|c|}
\hline \multirow[t]{2}{*}{ Denomination } & \multirow{2}{*}{$\begin{array}{c}\text { Unit of } \\
\text { measurement }\end{array}$} & \multicolumn{3}{|c|}{$\begin{array}{c}\text { Average of } \\
2001-2004^{\text {a) }}\end{array}$} & \multicolumn{3}{|c|}{$\begin{array}{c}\text { Average of } \\
2010-2014\end{array}$} & \multicolumn{3}{|c|}{$\begin{array}{c}\text { Change } \\
\text { (per cent) }\end{array}$} \\
\hline & & HU & $\mathrm{CZ}$ & SK & HU & $\mathrm{CZ}$ & SK & HU & $\mathbf{C Z}$ & SK \\
\hline \multicolumn{11}{|c|}{ Revenue } \\
\hline Price & EUR/tonne & 212.6 & 201.3 & 270.3 & 376.3 & 384.9 & 403.0 & 177.0 & 191.2 & 149.1 \\
\hline Yield & tonnes/hectare & 2.0 & 2.5 & 2.2 & 2.6 & 3.3 & 2.8 & 127.5 & 129.0 & 128.1 \\
\hline Sales revenue & EUR/hectare & 431.8 & 503.4 & 592.5 & 971.5 & 1246.5 & 1095.4 & 225.0 & 247.6 & 184.9 \\
\hline \multicolumn{11}{|c|}{ Variable costs } \\
\hline $\begin{array}{l}\text { Base variable } \\
\text { costs }\end{array}$ & EUR/hectare & 155.4 & 259.4 & 361.7 & 331.6 & 503.7 & 503.2 & 213.4 & 194.2 & 139.1 \\
\hline Seeds & EUR/hectare & 35.4 & 25.4 & 32.3 & 53.7 & 58.7 & 57.0 & 151.7 & 230.9 & 176.5 \\
\hline Fertilisers & EUR/hectare & 67.6 & 112.9 & 154.6 & 161.9 & 236.6 & 220.0 & 239.4 & 209.6 & 142.3 \\
\hline Crop protection & EUR/hectare & 52.4 & 121.1 & 174.7 & 116.0 & 208.4 & 226.2 & 221.5 & 172.1 & 129.4 \\
\hline $\begin{array}{l}\text { Other variable } \\
\text { costs }\end{array}$ & EUR/hectare & 138.6 & 71.8 & 124.2 & 231.5 & 136.0 & 155.5 & 167.0 & 189.3 & 125.3 \\
\hline $\begin{array}{l}\text { Total variable } \\
\text { costs }\end{array}$ & EUR/hectare & 294.0 & 331.2 & 485.8 & 563.1 & 639.7 & 658.8 & 191.5 & 193.1 & 135.6 \\
\hline $\begin{array}{l}\text { Gross margin } \\
\text { (all costs) }\end{array}$ & EUR/hectare & 137.8 & 172.1 & 106.7 & 408.4 & 606.8 & 436.6 & 296.5 & 352.6 & 409.2 \\
\hline $\begin{array}{l}\text { Gross margin } \\
\text { (base costs) }\end{array}$ & EUR/hectare & 276.4 & 244.0 & 230.9 & 639.9 & 742.8 & 592.4 & 231.5 & 304.5 & 156.6 \\
\hline
\end{tabular}

a) There were no data available for Hungary for 2000 .

Source: FADN 
Out of wheat, grain maize and rapeseed, rapeseed production needs the highest expenditure on inputs for efficient production in each of the three countries, as this crop tolerates differences in ecological conditions the least (Pepó, 2012). Base variable costs (input costs) - similar to the other crops evaluated in this chapter - were very similar in the Czech Republic and Slovakia, as an average of the period 2010-2014, at a little above EUR 503 per hectare. At the same time, the Hungarian figure was 34 per cent below this figure. Within total input costs, the cost of fertilisers represented the highest share in Hungary and the Czech Republic, at 48.8 per cent and 47.0 per cent respectively, followed by crop protection costs, with a proportion of 35.0 per cent in Hungary and 41.4 per cent in the Czech Republic. By contrast, in Slovakia the shares of crop protection costs (44.9 per cent) and fertiliser costs (43.7 per cent) in total input costs were very similar as an average of the period 2010-2014. The proportion of seed costs in total input costs was the lowest in each of the countries, at 11-16 per cent (Table 10).

Regarding the changes of the averages of the periods 2001-2004 and 2010-2014, gross margin of rapeseed production, calculated over all costs, increased the most in Slovakia (+209.2 per cent) as variable costs grew slightly here. However, because of its baseline value as an average of 2001-2004, this change was only enough for Slovakia to move, in respect of gross margin (all costs), from third to second place after the Czech Republic. Hungary realised the smallest increase of gross margin (all costs) in rapeseed production, as the development of sales revenue - which exceeded the Slovakian figure by 40.1 percentage points - could only partially compensate for the relatively high growth of variable costs, compared to the other two countries. As a consequence, the country dropped to third place in terms of gross margin (all costs) among the three countries. By contrast, the Czech Republic, with the second largest rise in gross margin (all costs), was able to maintain its leading position in rapeseed production (Table 10).

\section{Utilisation}

Oilseed rape has been the most important raw material of biodiesel production in the EU. The quantity of rapeseed used for biodiesel production varied between 14.5 million tonnes and 17.3 million tonnes during the period 2010-2014, which represented about 50 per cent of the total rapeseed supply (F.O. Licht, 2015; Tallage, 2015). During the same period, of the three countries, the Czech Republic used the largest quantity, an average of 484.0 thousand tonnes for biodiesel production, which represented 34.6 per cent of the country's total rapeseed supply. Slovakia used 193.4 thousand tonnes (47.0 per cent $)^{15}$ and Hungary 136.8 thousand tonnes $\left(22.1\right.$ per cent) ${ }^{16}$. Before 2004, biodiesel production did not or hardly existed in Hungary and Slovakia. In contrast, in the Czech Republic ${ }^{17}$, an average of 33.2 per cent of the total rapeseed supply (247.0 thousand tonnes) was used for biodiesel production during the period 2000-2004. After 2004, the volume of rapeseed used in biodiesel production increased intensively in each of the three countries (Figure 5), its share in total rapeseed supply reached 47.0 per cent in Slovakia, 34.6 per cent in the Czech Republic and 22.1 per cent in Hungary as an average of the period 2010-2014.

\footnotetext{
15 There is only one producer of biofuels from rapeseed in Slovakia: ENAGRO s.c. company. The average consumption of rapeseed for biofuels production (MERO) is about 210,000 tonnes per year.

${ }_{16}$ In Hungary, Rossi Biofuel Zrt. (in Komárom) has played a dominant role in biodiesel production since 2008. The company’s plant, which produces biodiesel by the process of transesterification, has a processing capacity of 150 thousand tonnes a year, and its yearly produced volume of biodiesel has approximately covered the domestic demand so far (Varga et al., 2013). Parallel with the development of biodiesel production in Hungary, the number of rapeseed oil processing companies has risen since 2005. Besides Bunge Zrt., Glencore Grain Hungary Zrt., Ökoil Kft. and Zöldolaj BB Zrt. are involved in rapeseed oil production with the aim of providing the raw material needs of biodiesel production (Tikász és Varga, 2015).

${ }_{17}$ There are only three companies producing certified FAME in the Czech Republic: Kratolia Trade a.s. (in Ústí nad Labem), Preol, a.s. (in Lovosice), and Primagra, a.s. (in Milín), with an aggregate capacity of 255 thousand tonnes, according to the data of the Association for Biodiesel Production.
} 
Figure 5: The volume of rapeseed used for biodiesel production in Hungary, the Czech Republic and Slovakia, 2000/2001-2014/2015.

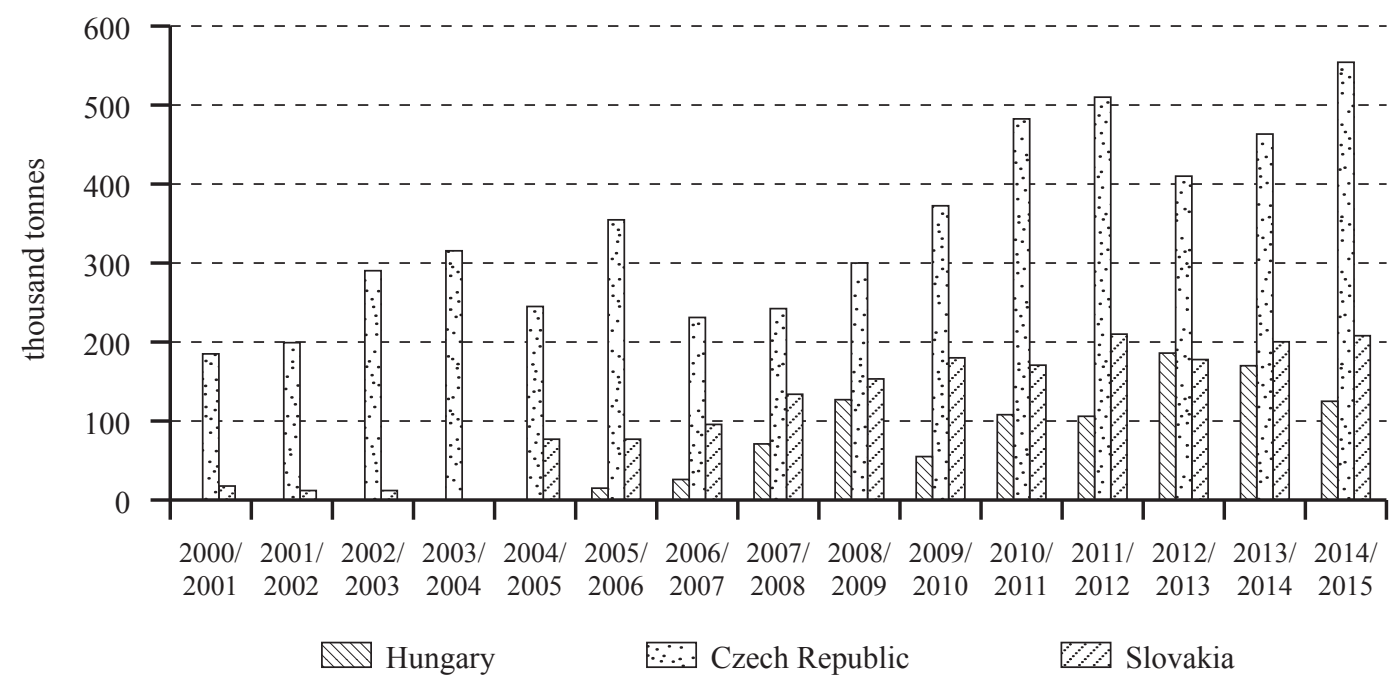

Source: HCSO, Tallage, CZSO, MZe, ÚZEI and SO SR

\section{Foreign trade}

Domestic rapeseed production easily covers the needs of rapeseed processing in all the three countries, the level of self-sufficiency was 428.0 per cent in Hungary, 132.0 per cent in the Czech Republic and 153.5 per cent in Slovakia as an average of the period 2010-2014. However, average rapeseed imports between the five-year periods of 2000/2001-2004/2005 and 2010/2011-2014/2015 increased from 0.2 thousand tonnes to 95.0 thousand tonnes in Hungary, from 41.2 thousand tonnes to 124.8 thousand tonnes in the Czech Republic and from 4.5 thousand tonnes to 81.7 thousand tonnes in Slovakia, mainly because of the presence of multinational trading and processing companies in all the three countries (Figure 6).

The share of the volume of rapeseed exports in the total rapeseed supply shows huge differences in the three countries. More than 88.4 per cent of the total Hungarian rapeseed supply (567.4 thousand tonnes) was sold on foreign markets as an average of the period 2010-2014. This was the fourth largest quantity in the EU-28 (after France, Romania and the Netherlands) and Hungary represented 8.0 per cent of the total EU rapeseed exports (extra and intra together). In the same period, Slovakia exported 47.3 per cent of its total rapeseed supply, 272.5 thousand tonnes. In contrast, the Czech Republic rather produces rapeseed for domestic processing; its average export quantity represented only 28.9 per cent of the total rapeseed supply, although the volume of the shipments amounted to 412.4 thousand tonnes. As regards the changes during the last 15 years, parallel with production growth, rapeseed exports increased in the three countries, showing high volatility after 2009, due to the changes in production, as well as in the demand of the processing industry. As a consequence, in the marketing years 2012/2013 and 2013/2014 the exports of the Czech Republic exceeded those of Hungary. Between the averages of the periods 2000-2004 and 2010-2014, the largest increase in the average quantity of rapeseed exports occurred in Hungary (+292.9 per cent) and Slovakia (+272.5 per cent), due in particular to the high levels of illegal trade (cross-border VAT fraud) ${ }^{18}$ (Figure 6).

\footnotetext{
18 Until introducing reverse-charged VAT in 2012, in Hungary, as an average of the period 2010-2012, around 100 thousand tonnes of rapeseed
} crossed the border to Slovakia only on paper, according to mirror statistics (Varga et al., 2013). 
The two most important export destinations of Hungarian exports were Germany and Austria during the whole period observed, and 72.7 per cent of total rapeseed exports went to these countries as an average of the years 2010-2014. The Czech Republic's main target market was Germany too, the country shipped 65.3 per cent of its total rapeseed exports to this destination as an average of the period 2010-2014. Slovakia has also been an important rapeseed market for the Czech Republic after Germany, however the traded quantity was much smaller, only 15.1 per cent of total rapeseed exports. Meanwhile, Slovakia exported most of its rapeseed to Hungary, the Czech Republic and Austria. The traded volume changed substantially in each of the countries year-by-year, so the position of the most important partner countries varied almost every year during the period observed. Because Hungary and the Czech Republic each accounted for little more than 7 per cent of Germany's annual rapeseed imports over the period 2010-2014, they regularly competed for third place in the ranking of suppliers. Besides, in the German market, the positions of both countries are jeopardised by the increasing quantity of rapeseed coming directly and indirectly (probably through Belgium) from Australia, the world's second largest rapeseed (canola) exporter. Similarly, supplier competition in the Austrian rapeseed market existed between Hungary and Slovakia. Hungary has been the leading rapeseed supplier of Austria during the 15-year period, consistently supplying around 55 per cent of Austria's total rapeseed import demand during the period 2010-2014. By contrast, the quantity of Slovakia's exports to Austria are highly volatile, varying between 10 and 200 thousand tonnes year-by-year. Thus, Slovakia from time to time has threatened Hungary's leading supplier position in the Austrian rapeseed market.

Figure 6: Foreign trade of oilseed rape in Hungary, the Czech Republic and Slovakia, 2000/2001-2013/2014.

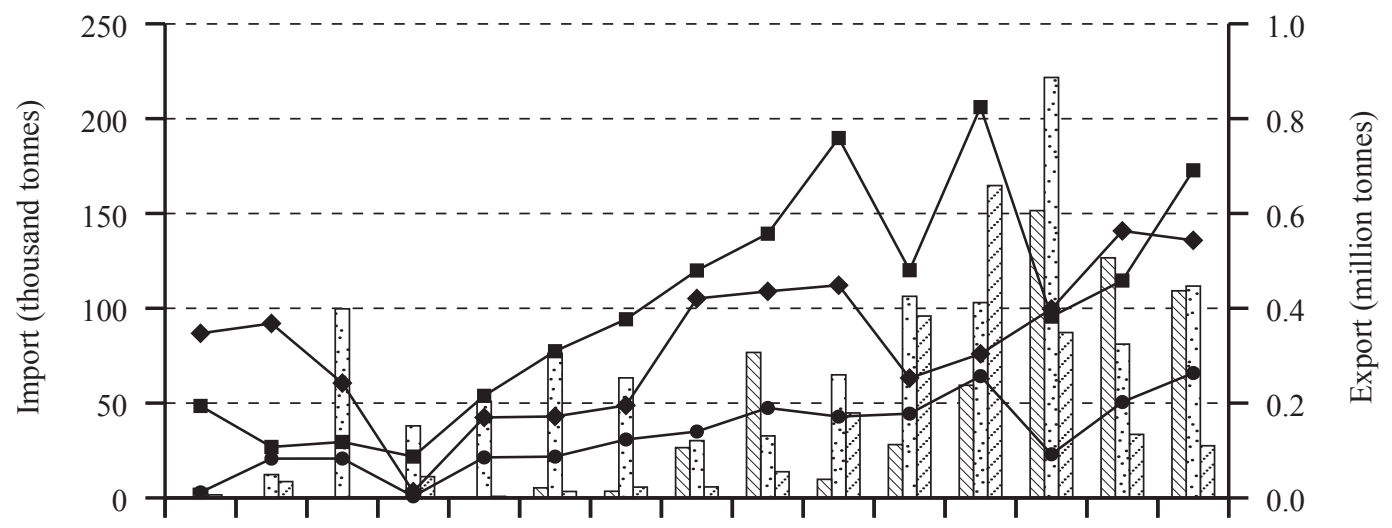

2000/2001/2002/2003/2004/2005/2006/2007/2008/2009/2010/2011/2012/ 2013/ 2014/ 200120022003200420052006200720082009201020112012201320142015
MV Import Hungary
$\because$ Import Czech Republic
Import Slovakia
$\rightarrow$ Export Hungary
$\checkmark$ Export Czech Republic
$\rightarrow$ Export Slovakia

Source: HCSO, CZSO, MZe, ÚZEI and SO SR 


\section{Conclusions}

The aim of this chapter was to introduce the Hungarian, Slovakian and Czech wheat, grain maize and rapeseed producing sectors by comparing their developments and competitiveness in the light of the impact of the CAP on the effectiveness of these sectors. The points thought to be of most crucial importance are as follows:

- The production of wheat, grain maize and rapeseed increased in the three countries, without exception, during the time frame of the analysis, primarily driven by higher yields, secondly by the increase in the harvested area in the case of rapeseed in all of the countries and maize in the Czech Republic and Slovakia. In some cases, sharp improvement in per hectare yields could be observed, especially in the Czech Republic, due to the adoption of new varieties. However, yields in all the three countries were far behind the yields of the leading producer EU Member States and often from the average yields of the EU-28, mainly because of underdeveloped production practices.

- Despite the concentration process taking place in the crop producing sectors of all the three countries, the proportion of small wheat and maize producing farms, managing fragments of the total crop area, was still very high in Hungary and in Slovakia in 2013. Meanwhile, the farm size structure in the Czech Republic is closer to the structure of the major western European producing countries, mainly due to the exclusive growth in the number of farms managing more than 50 hectares of crop during the period 2005-2013, in contrast to Hungary and Slovakia, where the same increase could be observed by all farms with a crop area over 5 hectares. This resulted in an almost similar average physical farm size for all the three crops in the Czech Republic, while in Slovakia and Hungary the average farm size of wheat and maize production were half, or one third of that of rapeseed production.

- The competitiveness of different crop producing farms now depends much more on cost-effective production than before the accession of these countries to the EU in 2004, as crop prices, due to globalisation, became an external factor. This process is shown in the equalisation of commodity prices between the countries.

- As an average of the period 2010-2014, the rank of the three crops based on their gross margin (calculated over all costs) was the same in Hungary and Slovakia, where grain maize production was the most, and wheat production the least profitable. In the Czech Republic, rapeseed production reached the highest gross margin and wheat production the lowest, such in the case of the other two countries. At the same time, comparing the gross margins of the three countries for each crop, the Czech Republic was the most effective, as yield improvement, due to high direct expenditure in favour of production, resulted in the most intensive development of gross margins here. Also, the larger producing area of the farms in the Czech Republic contributed to more cost-effective production, which showed the most spectacular differences in the case of other costs (e.g. machinery) in the three countries. By contrast, with the lowest gross margin, Hungary's crop production was the least effective during this period, which can be interpreted via extremely high other variable costs and also the weakening of the Forint compared to the Euro.

- After the accession to the EU, unrestricted market access lead to growing foreign market opportunities in all the three countries. Different exploitation of market potentials boosted commodity imports but primarily exports, as the high rate of self-sufficiency in each of the crops allowed an increasing presence on EU markets, in particular for Hungary, being the most export oriented of the three countries as regards raw material. However, owing to new competitors continuously entering these markets from inside and outside the EU, securing market share is becoming a growing challenge for market participants. 
In summary, the overwhelming weight of area-based decoupled payments under the SAPS and EU biofuels policies accompanied by developments in crop genetic resources and the increase in commodity prices and unrestricted export opportunities to EU markets boosted the production of wheat, grain maize and oilseed rape, as well as the production efficiency - albeit much more moderately and at a different level - in these sectors in Hungary, the Czech Republic and Slovakia during the period 2000-2014. 


\title{
Competitiveness of the pig sector
}

\author{
NAGY, László ${ }^{1}$, ABRAHAMOVÁ, Miluše ${ }^{2}$ and GÁLIK, Jozef ${ }^{3}$
}

\section{Introduction}

The pig sector is the largest and most important livestock sector in the EU. The EU is the world biggest exporter of pigmeat and the second biggest producer with 152 million pigs and a yearly production of about 23 million tonnes of carcass weight in 2014. The EU has a self sufficiency of about 110 per cent and exports about 12 per cent of its total production. More than half of the pigmeat were produced in four countries of the EU (Germany, Spain, Denmark and France) (OECD and FAO, 2014). Only 3,5 per cent pigmeat production (about 5 million pigs) in the EU come from Hungary, the Czech Republik and Slovakia. In the chapter we assess the main impacts of EU accession on the pig sectors in the three countries. After comparison of the importance of production, consumption and trade, we draw conlusions about the development of the sector.

\section{Main impacts of EU accession}

After EU accession the number of pigs significantly declined in all three countries. In Hungary many pig farmers quit production because the financing of losses became unbearable. Before Hungary's accession to the EU many small private (farm) and municipal slaughterhouses could not undertake the necessary developments to comply with EU regulations. The rest of the small slaughterhouses shouldered the costs of obligatory qualifications. Since the 1990s, and even more since Hungary's accession to the EU, the productivity and output of the Hungarian pig sector have declined constantly, which is clearly shown in the decrease in livestock. In 2012 there were fewer than 3 million pigs on the farms (Figure 1). Hungary lost its net exporter position in 2005 because the volumes of imported live pigs and pigmeat are very high. The profitability of livestock production declined compared to crop production after Hungary's accession to the EU. Lack of direct payments, a small share of investment support, lack of capital and unpreparedness are the factors which hit this sector. According to the opinions of experts, generous support before the EU accession period and the lack of targeted agricultural policy are the reasons why livestock production does not have a developed, viable, competitive and efficient structure.

In the Czech Republic, integration into the EU single market also put the pigmeat sector under strong competitive pressure from other Member States. Among the livestock production sectors, breeding pigs suffered the greatest downturn after 2004. The Czech Republic had been experiencing a decline in pig numbers since 1990. The rate of decline accelerated following EU accession, until 2011 when the trend halted. In 2012 and 2013 there was a gradual recovery of farms and the number of pigs increased slightly. From 2002 to 2011 the total number of pigs in the Czech Republic fell by 56.6 per cent according to the Czech Statistical Office (CZSO), a loss of 1.9 million animals. Numbers in the basic herd of sows over the same period decreased by 67.2 per cent ( 199 thousand) as their number dropped to below 100 thousand. The rate of loss of sows significantly accelerated in 2008 when compared to 2007 their numbers fell by nearly 25 per cent. Another 21 per cent decline was experienced between 2010 and 2011. During the next two years (2012 and 2013) there was a gradual expansion of herds. The total number of pigs increased by 4.1 per cent (by 60.5 thousand) from 2011 to 2014 , and sows increased by 5.6 per cent (5.4 thousand). One reason for this improvement from 2011 was the newly established national subsidies (state aid). This support was aimed at preventing the spread of diseases in pigs and was paid to breeders of pigs and sows engaged in rejuvenating and sanitising the breeds.

\footnotetext{
Research Institute of Agricultural Economics, Budapest, Hungary.

Institute of Agricultural Economics and Information, Prague, Czech Republic.

National Agricultural and Food Centre - Research Institute of Agricultural and Food Economics, Bratislava, Slovak Republic
} 
Figure 1: Pig livestock numbers, 2003-2014.

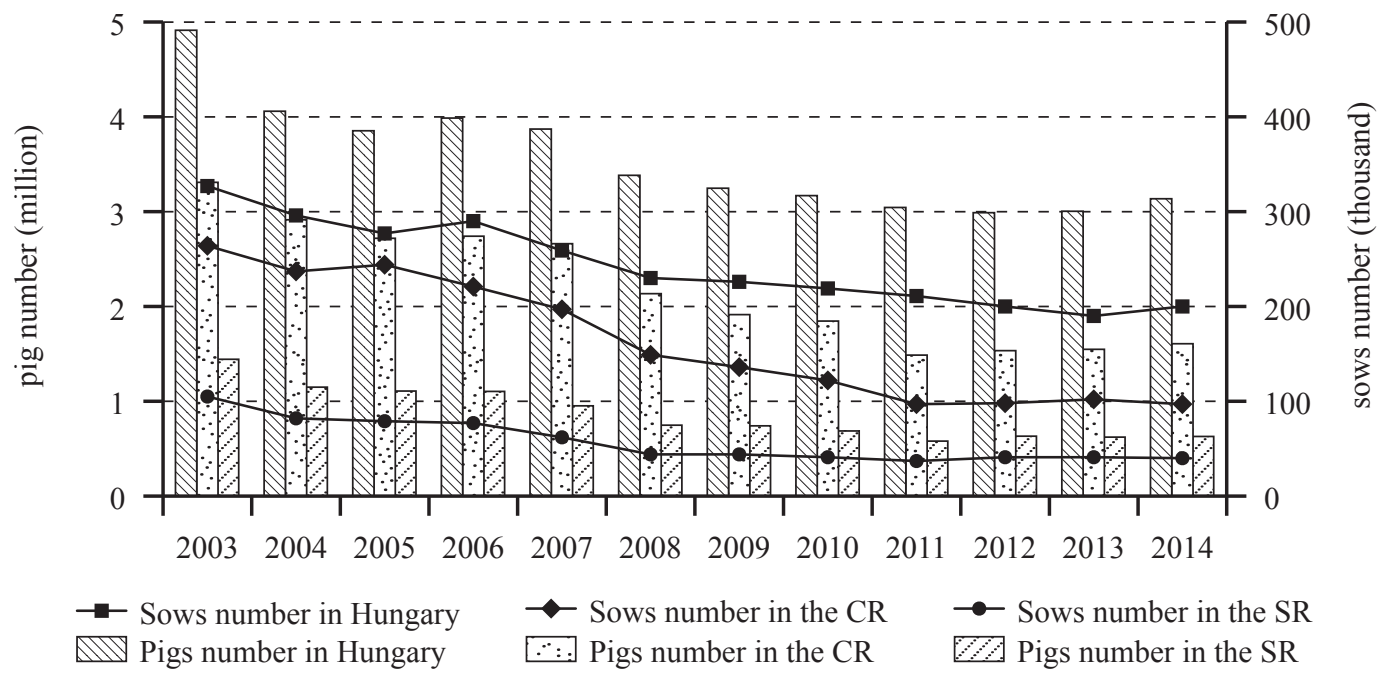

Source: HCSO, CZSO, SO SR

The main reason of the decrease was the negative profitability of pig farming and the low competitiveness of the meat processing industry. Further deterioration in competitiveness was due to unfavourable developments in this sector in the world and Europe in the period 2007-2008 from which the Czech sector has not recovered yet. The result was a significant deterioration in the economy of domestic production of pork accompanied by a reduction in the number of pigs, particularly sows, as well as a dynamic growth of imports. Consumer demand has been relatively stable over the last ten years, but the share of imports grew and worsened the rate of self-sufficiency.

Czech pig production is concentrated in relatively large companies, a legacy from the period before 1989 and the so-called "common agricultural holdings". Some of these companies ended production in the 1990s, others transformed their company into a limited liability or joint stock company. The downside is that most of these specialised pig businesses have a narrow diversification of production: they are mainly focused on breeding poultry and pigs, running mostly landless. They must therefore buy all the food and do not receive any direct payments. That makes them more sensitive to price volatility of the final product, but they are under more pressure to meet the environmental protection and animal welfare standards. The size of enterprises in the Czech Republic aimed at breeding pigs, however, does not seem to yield an advantage in terms of economic indicators, in many cases their production efficiency in comparison with small businesses is not any better. As for territorial distribution, almost 60 per cent of pig farms in the Czech Republic are concentrated in four regions (Highlands, Central Bohemia, South Moravia and South Bohemia), the fewest pigs are kept in northwestern Bohemia and districts of Karlovy Vary, Liberec and Ústí nad Labem.

With the decline in the number of pigs in the Czech Republic there was also a reduction in the number of companies engaged in their breeding and a concentration into farms with more animals. For example, in 2006, there were registered a total of nearly 4.69 thousand pig farmers with an average number of 621 animals in a company. Almost 74 per cent of the pigs bred in the Czech Republic belonged to 322 enterprises with an average concentration of more than 2 thousand pigs. By 2014, the number of pig farmers in the Czech Republic fell by almost a half, as only 2.5 thousand enterprises continued breeding. The average number of animals in a company rose by 9.0 per cent to 674 units. Almost 82 per cent of pigs were kept in 172 enterprises with a concentration of animals in excess of 2,000 units. The reduction was even more pronounced (for economic reasons) in breeding 
sows. Here, from 2006 to 2014 the production of piglets was closed in more than 63 per cent of the enterprises and at the end of 2013 there were only 1.7 thousand still running. More than half of all sows are now concentrated in 48 companies with over 500 individual sites.

Breeding sows associated with the production of piglets is economically the most difficult element in this sector, which is why so many farms stopped. This trend was evident across the EU. Downsizing of the basic herd of sows in the Czech Republic has gained rapid pace especially since 2007 and resulted in a decreasing number piglets born and bred. While in 20045.4 million piglets were weaned, in 2011 it was only 2.7 million piglets. A slight improvement had occurred by 2014, when the rearing increased by 0.7 per cent to 2.7 million units. Missing piglets for fattening had to be increasingly replaced by imports.

In Slovakia, pig farming experienced several crisis periods during the last decade. It is still not able to regenerate from the crisis that has persisted in the sector, with small exceptions, since 2002. The reason for this is Slovakia's lack of readiness for EU accession and the related absence of more marked grant incentives for pig farming development. This is considered to be a principal disadvantage compared to neighbouring countries and reflects in the optimum level of market price which would be competitive in the Central European region and pivotal for sector development. During whole period, only in 2009 was subvention per sow provided to pig keepers (approximately EUR 50 ), which succeeded in short-term mitigation of the pace of decline in the number of pigs.

In Slovakia between 2002 and 2011, pig herds decreased from 1,554 thousand head to 580 thousand head (-62.7 per cent); concurrently sows herd declined by 68.2 per cent (from 117.5 thousand head to 37.4 thousand head) (Figure 2). During only the past three monitored years was moderate growth of pig herds as well as sows noted. Because of the lack of state support mechanisms in pig husbandry, development of producer prices had a crucial influence on the number of livestock. The development of slaughter pig farm gate prices had not been favourable for farmers, negatively affecting profit-cost ratio of production and generating losses in many pig enterprises. Slaughter pig prices classified into trade classes S, E, U and R as well as average prices during the period 2002-2010 show declining trends. Since 2011 the trend has changed and farm gate prices have started to rise, in 2013 reaching the price level of 2004. Despite these lower price level, there was a significant improvement in meat quality during this period.

Figure 2: Development of pigs number and average producer prices of slaughter pigs, 2002-2014.

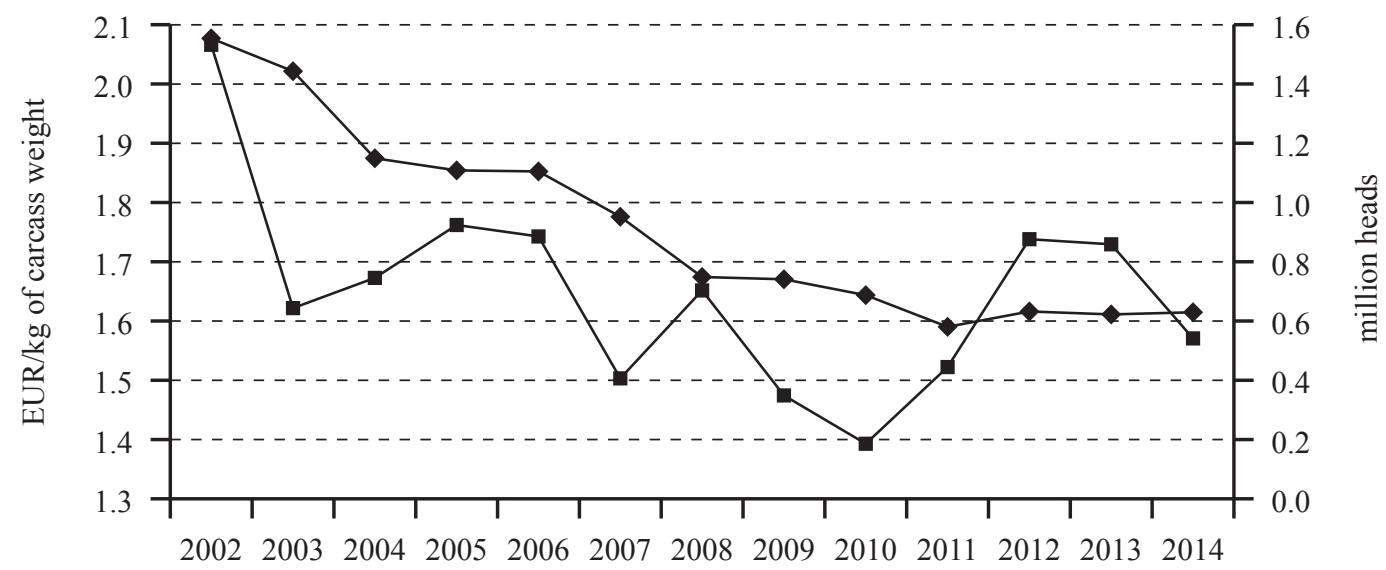

Average Producer Prices

Pigs number

Source: SO SR, NAFC-RIAFE 


\section{Production}

At around $3.2 \mathrm{~kg} / \mathrm{kg}$, feed efficiencies in the pig sector in Hungary are very low and, given the current high feed prices, the cost of feed per kg of live weight gain is a tremendous burden. Although pigs reach acceptable indices in small scale experiments, the results are much worse in practice. Illegal production can distort efficiency indices, when more animals are fattened on the feed than are shown in the books, but there are real existing deficiencies which affect feeding productivity. Low fertility rate, high culling rate, veterinary problems, raising sensitive breeds with low tolerance, low quality feed and inappropriate feed composition can all increase specific feed usage. Fertility, daily gain, feed efficiency and farrowing rate are all lower, fattening time is longer, and the working time spent on the animals are higher. Official statistics show a substantial lag: 16 weaning piglets raised per sow per year. Small farms often lack not only capital, but also appropriate knowledge of animal husbandry. The efficiency of slaughtering pig production is lagging behind the competition.

In Hungary pig breeding has a bipolar structure. There are partly self-sufficient producers and small factories, which sell only the surplus production, while on the other hand there are privatised former state owned companies and co-operatives with partly or fully modernised large plants with large numbers of livestock even in comparison with Europe as a whole. The EU is characterised by middle-sized producers, which are a missing segment in Hungary. Unlike in many leading pig producing countries, in Hungary most pig farms have not specialised, despite breeding and fattening requiring different technologies. Culled breeding animals are replaced by animals bred on the farm, which generally leads to reduced prolificacy and natural productivity. New genetic research and innovation are neglected and not applied in practice. Even if farmers use modern genetics and varieties they are often not able to ensure the necessary conditions which would allow the high genetic potential to be reached. Breeding stock in Hungary is heterogeneous; the basis of the selection is narrow.

Despite the modest efficiency indicators, there are also strengths. These are also typical of the Hungarian pig sector and will result in the improvement of competitiveness. More and more farms use modern, high-performance breeds, from which improved indicators of efficiency can be expected. However, the poor feed conversion is due to the difference in the feeding technology. In Hungary, the utilisation of by-products is less typical compared to the Netherlands. This is mainly due to the low wet feeding systems and because Hungary has excellent maize and wheat growing areas. Therefore, maize and wheat-based feed is ensured in the long term. There is currently an export market - South Korea - which buys Hungarian grain-fed pork exclusively. The farmers in the new pig farms are open to using by-products. This may result in reduced costs. The legislation on using animal proteins in feeds is expected to be revised in the near future and this also may result in reduced costs.

Hungarian pig holders have to overcome difficulties originating from the geographical location. Hungary has a continental climate, which imposes higher heating and cooling costs. Since seaports are far away, both importing protein meal and other feed ingredients and exporting through the ports to third countries are more expensive. Waste management costs and the costs of handling and disposing of animal corpses are also high in international comparison. During the last decade a growing number of thefts and other crimes against property have been reported by producers, and crime prevention investments and costs have also increased production costs.

Weak profitability and the insecure outlook of the sector have triggered concentration. At present, the livestock number of private pig holders is only half of the former 2.25 million; now 75 per cent of the livestock is held by commercial enterprises. Vertical and horizontal integrations are rare and weak and often inefficient, playing only minor role in the supply chains. Business relationships can seldom be described as trustworthy; business decisions are often based on short term profit, not on long term mutual benefits, and this makes partners unpredictable and forming integration and coop- 
eration rather difficult. It has not yet widely realised that common interest can be the foundation of setting up a long term strategy that is acceptable to producers, processors and all other market participants. It is expected that as a result of government measures the integrations will be strengthening and, parallel to this, development of consultancy network can be realised. There is a chance of this realisation, because many Hungarian substantial businessmen think that investing in the Hungarian pig sector is a good investment. For example, despite the significant pork imports the pork trade balance is positive due to the export of high-value-added products and many Hungarian pork products are world famous (Pick, Hertz).

Large private companies and agricultural enterprises have difficulties in finding dependable employees, due to the low wages. Employment can be even more crucial in the case of start-up businesses, although there are not many working opportunities in rural areas. There are problems about maintaining technological discipline, and as mentioned above, property security issues often arise. Education is not focused enough on practice, which results in a longer training period. There is a considerable demand among farmers for technical advice, for independent expertise. Most of the reliable experts are hired by input suppliers and their advice can be somewhat partial. Public consulting services have to be improved significantly in order to support the necessary development, and the competitiveness in the sector. Again, forming integrations would help in coordinating knowledge transfers efficiently. Some improvements can be expected from the Hungarian Chamber of Agriculture.

Most of the large pig farms operating in Hungary were designed and constructed in the 1970s. The technology and the construction usually allow every animal to be held in closed buildings, sometimes with open ranges for sows and for fattening pigs. Sows are held in group housing and without bedding. Piglets are weaned after 28 days; weaned piglets are held in groups in closed buildings with partly slatted concrete floors. Ventilation is often achieved with pressurised technology. Farms have separate buildings for the different age groups, which are often built with light structures, sometimes from prefabricated panels. About 80 per cent of farms have closed buildings, 10 per cent have open paddocks or yards, while 10 per cent have only one consolidated building and animals are moved only between pens and sectors within this, which is better for automatic operations and machinery but worse concerning elasticity. About 90 per cent of farms need to be renewed or renovated, since only one in ten is using up-to-date technology. Most farms are not able to use wet by-products for feed, and in this way save on feeding costs, because just a few premises have a wet feeding system installed. The basic feeds are usually maize, not by-products, which favours meat quality, but higher quality is not always accompanied by a higher sale price. Changing the technology or renovating and restructuring buildings require huge investments.

Many pig farmers do not have enough land of their own, or rented, to produce all of the necessary feed and to dispose of manure, although both have a significant impact on the security and profitability of the operation. Increasing feeding costs, compulsory investments concerning manure handling and adverse conditions on land use have caused many farmers to quit the pig business.

Low productivity due to inappropriate technology has forced more and more farmers and enterprises to invest in replacing the outdated equipment with new (Danish or German) technology. New buildings are usually equipped with computer controlled air conditioning and ventilation systems. The new feeding systems can often work automatically: the water saving drinking troughs, nipples or bowls can save costs even for the manure handling. On some farms it is possible to feed sows with individual rations with the help of a computer controlled identification system, but this is still rare compared to group feeding.

Using sewage and manure for biogas production is an option which was analysed and evaluated by many farms. Some had already considered biogas when the manure storage facilities were built. 
According to the current support schemes, 40 per cent of the building costs of biogas plants can be supported, but the problem lies with the operating costs and returns. Preliminary calculations have shown that owing to low tariff rates for renewable energy and because of the difficulties in utilising waste heat, investing in biogas plants linked to the pig farm does not produce sufficient return under the present conditions.

Specialisation on fattening or on breeding is not common in Hungary, most of the farms hold breeding animals and also growing pigs for slaughtering. On small farms piglets are raised in a onestage procedure, piglets stay in their birth pen until they are 2-3 months old and they are moved only at the start of the fattening period. On large enterprises piglets are raised in two steps, after weaning they are held in piglet rearing pens.

Many producers are considering changing genetics in the future. Hungarian breeds are producing very good meat quality but their prolificacy is lower than the popular world breeds. When the domestic breeds were developed Hungary had a strong position in the German market, which demanded a high lean meat ratio. Breeding strategies focused on that, leaving reproductive characters slightly neglected. Raising premium pigs with high meat ratio also increases production costs, and processors are now often not willing or able to pay the difference for the premium meat quality, since their consumers are not able to pay for that either.

Reproductive indicators of breeding sows in the Czech Republic, despite the loss of sows in the last ten years, have been steadily improving. At present the average level for some Czech breeders equals the standards of countries such as Germany or Austria, but there is still room for improvement. The number of piglets born per sow reached almost 28 in 2013 (Figure 3). Compared with 2004, this represented an increase of 31 per cent, i.e.by 6.6 piglets. Similarly, this period saw an increase in the number of weaned piglets per sow by 31.6 per cent (about 6 piglets) to 25 . Also, data on the annual number of litters per sow attributable to the period from 2004 to 2014 improved by 11 per cent. In contrast, the mortality of piglets did not change significantly during the reporting period and consistently exceeded 10 per cent, while in 2005-2008 it even increased slightly to over 11 per cent.

Figure 3: The indicators of reproduction of the sows farming in the Czech Republic, 2002-2014.

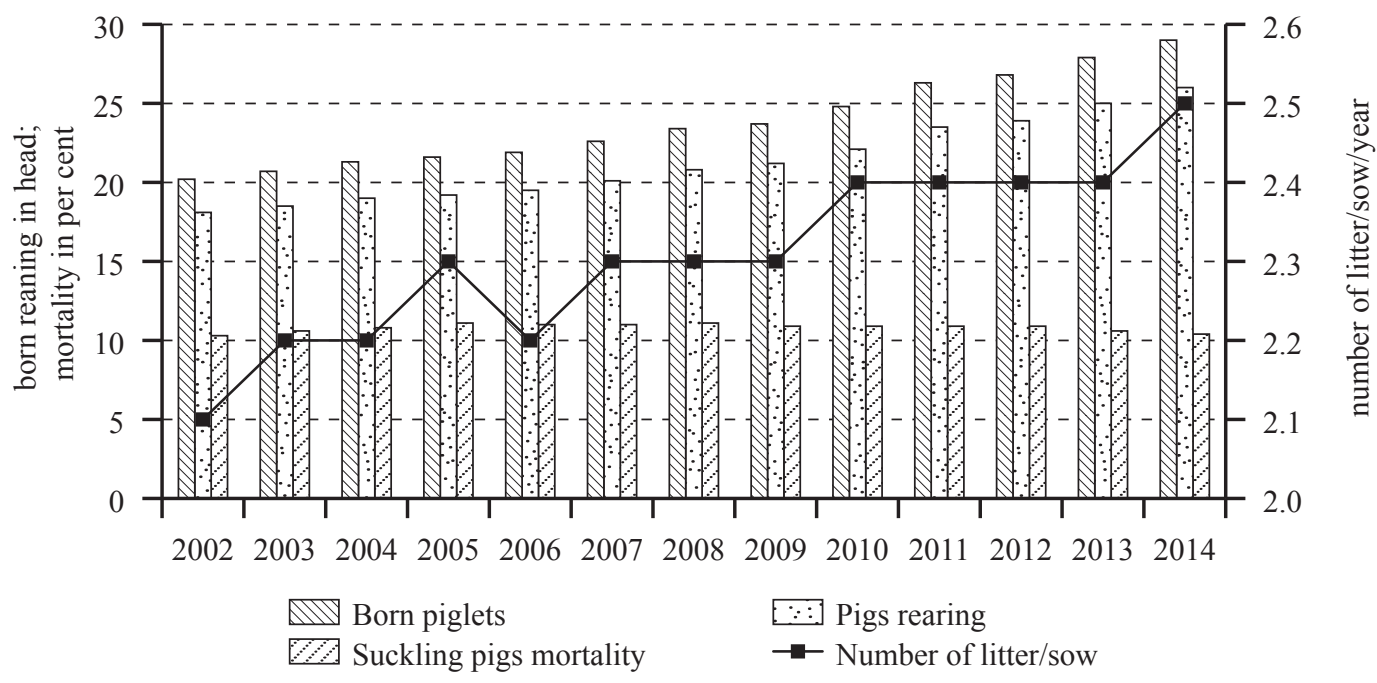

Source: CZSO 
In 2012 one sow produced $1,778 \mathrm{~kg}$ slaughter weight, lean meat reached 1,007 kg slaughter weight. Year on year, these values are also constantly improving. The increase in fattening pigs is another indicator that recorded over the last ten years a slight improvement. From 2004 to 2014 it increased by nearly 15 per cent, i.e. $0.1 \mathrm{~kg}$ per fed day. Relatively high values are recorded in the Czech Republic in feed conversion to fattening pigs, when a $1 \mathrm{~kg}$ increase accounts for about 3.2 $\mathrm{kg}$ of feed, which is a large margin for improvement in this indicator to influence the economics of production.

In Slovakia, apart from subsidies, only improvements in the reproductive and efficiency parameters could contribute to the development of the pig sector. Production intensity in pig feeding measured through average gain per feed day is currently approaching $0.6 \mathrm{~kg}$ per feed day. From the technological level and feedstuff quality points of view, pig feeding constantly achieves a low intensity level whereby the total feeding period is extended and therefore slaughter pig production surcharges and, as this has an influence on the low competitiveness of domestic pig producers against foreign competition. Conversely significant advances are noted in the development of reproduction indicators: the numbers of litters and matured piglets per sow have markedly increased. While in 2002 there were 15.7 matured piglets per sow, the figure was 23.4 in 2014. This increase was achieved despite the fact that pig farming has not modernised due to financial constraints. Moreover, many farms cannot obtain regular genetic material for reproduction and quality feedstuffs. There is a high percentage of mortality among sows as well as weaners despite a declining trend. This indicates that there would be huge benefits from improvements in the level of care (production costs could be reduced significantly by an increased number of pigs per handler and a larger herd size could lead to savings on veterinary costs), but also in new building and stall technologies which would provide a better environment for the pigs.

To main reasons for the significant decrease in pig meat production are: establishment of foreign trade chains on the Slovak market that have fully used the liberalisation of the international trade environment, higher growth rate of input prices in pig management as compared to development of slaughter pigs prices, a low level of local patriotism of Slovak consumers who prefer low price products without reference to the country origin, a huge surplus of production of slaughter pigs in the EU, the sales aimed at live slaughter pigs at the expense of processed meat products. Also the significant reduction in processing capacity (mainly the liquidation of large slaughter houses) have restrained the sales possibilities and minimised the price competition.

The unfavourable development of slaughter pig purchase prices, that dropped very markedly below the level of production costs in Slovakia, reduced the possibility of making a profit from pig meat production or yet to achieve the break-even point of production. At the same time the absence of adequate subsidies did not create conditions for the long-term economic sustainability and development of pig management in Slovakia.

The price pressure generated by trade chains has been solved by pig meat imports from Germany, Denmark or Spain to the domestic processing industry and so the opportunities for Slovak slaughter pigs sales have been limited. An increase in employment and consequently higher buying power of inhabitants generates the higher demand for more expensive meat and meat products from domestic provenance. Respectable supplier-costumer relations between producers, processors and trade and a higher volume of slaughter pigs processing by Slovak meat industry might create the conditions for the increase in the supply of Slovak pig meat and they might contribute to the eventual stabilisation of the development of pig management in Slovakia. 


\section{Consumption}

Average consumption of meat, meat products and offal in Hungary in 2013 was $55.5 \mathrm{~kg}$ per capita (in meat equivalent), of which 96 per cent related to raw meat and products, and the remaining part to offal. Total meat consumption decreased significantly in the 1990s and 2000s, and the structure of consumption also changed during that time. This resulted in a decrease in the total share of meat and offal consumption from 36 per cent at the beginning of the 1990s. The domestic demand for poultry meat increased during the 1990s and declined in the subsequent decade. In terms of consumption, pig meat and poultry meat are nowadays the most important types of meat in Hungary (Table 1). Pig meat consumption in Hungary fluctuated between $25-27 \mathrm{~kg}$ per capita (44 per cent) in the $2000 \mathrm{~s}$, lagging behind the EU-15 by around 48 per cent. The domestic sales of chopped pork (loin, rib and thigh) and half-carcasses did not change significantly in 2013. This is to be attributed to domestic pig meat prices following closely the price trends in the major pig producing Member States of the EU. Pig producer prices were HUF 477.3 per kg (warm carcass weight) in 2014, 3 per cent below the level in 2013. Rising prices can be explained by the weakening of the Hungarian forint, because the slaughterhouses purchased imported pigs at higher prices.

Table 1: Balance of meat consumption in Hungary, 2000-2013

$\mathrm{kg}$ of deadweight per resident

\begin{tabular}{lrrrrr}
\hline \multicolumn{1}{r}{ Specification } & \multirow{2}{*}{$\mathbf{2 0 0 0}$} & \multirow{2}{*}{$\mathbf{2 0 0 5}$} & \multirow{2}{*}{$\mathbf{2 0 1 3}$} & \multicolumn{2}{c}{$\mathbf{2 0 1 3}$} \\
\cline { 5 - 7 } & & & & $\mathbf{2 0 0 0}=\mathbf{1 0 0}$ & $\mathbf{2 0 0 5}=\mathbf{1 0 0}$ \\
\hline Total meat with offal & 73.3 & 66.2 & 57.7 & 78.7 & 87.2 \\
\hline Including: meat & 70.2 & 63.5 & 55.5 & 79.1 & 87.4 \\
\hline Including: pig meat & 28.0 & 26.7 & 24.0 & 85.7 & 89.9 \\
\hline beef & 4.3 & 3.1 & 2.2 & 51.2 & 71.0 \\
\hline poultry meat & 33.7 & 29.8 & 24.9 & 73.9 & 83.6 \\
\hline
\end{tabular}

Source: HCSO

Hungarian consumers are very price sensitive and this has been even more true since the start of the economic crisis. The price is the first on the preference list of the consumers: it is not easy to sell premium products on the Hungarian market. Retail chains have introduced private label products and brands and their market share is growing dynamically. Producing private label products for a retail chain is often challenging for a processor. Some choose to sell the same quality as they assure for producer's label products, but quality is often the victim of the low prices (Popp and Potori, 2009). Between 2006 and 2014 the increase of pig meat retail prices was higher than the pig meat sales prices, but the buying in prices of pigs were the highest (Figure 4). Therefore, the number of slaughterhouses decreased significantly. According to stakeholders, the incidence of the black economy in the pig sector is significant. The most common type of black marketing is where the product is sold by farmers to processors and by processors to butcheries or even to wholesale companies without a receipt. Reporting the export of live pigs or pig meat and claiming a VAT refund is also common, although the export transaction exists only on paper, and the animals are slaughtered and sold illegally on the domestic market (Varga et al., 2013). The pig sector became more transparent with the reduction in the level of VAT in 2016. 
Figure 4: Prices of pig meat in per cent in Hungary, 2006-2014.

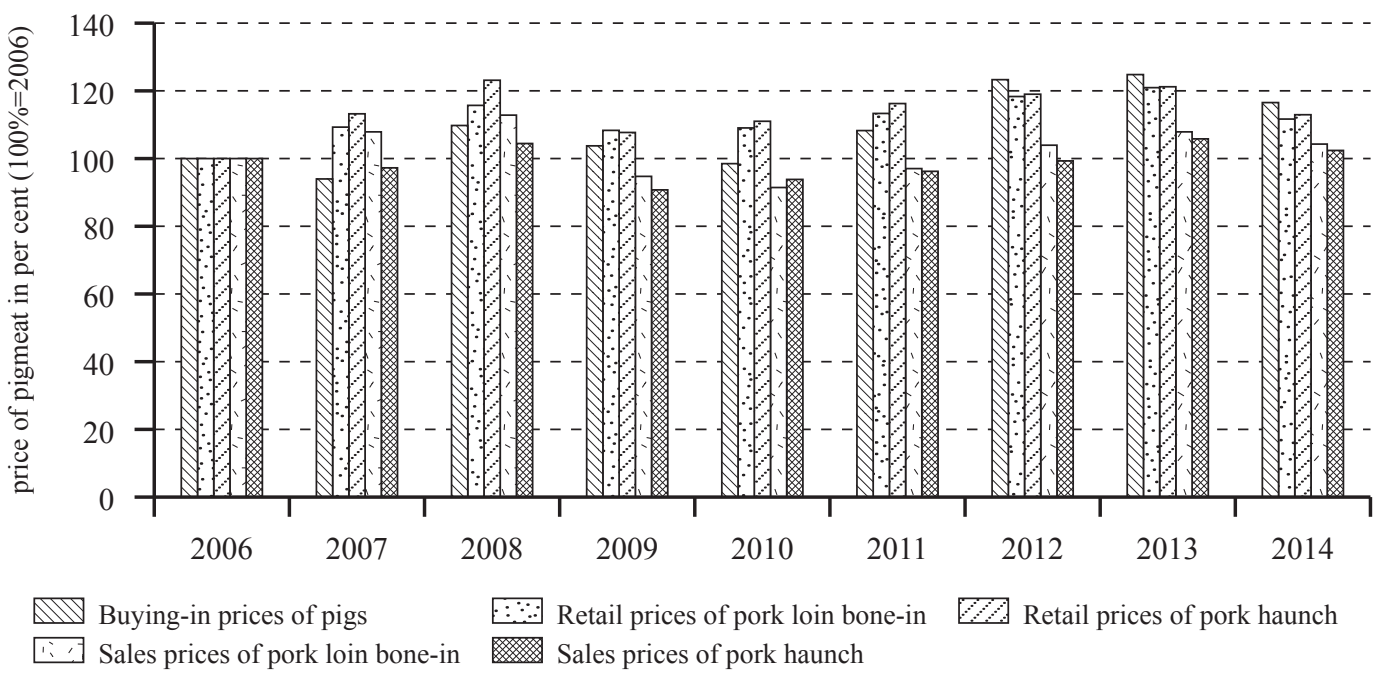

Source: AKI, HCSO

In the Czech Republic, pig farming and pork production have long traditions. In the preceding twelve years, production was negatively affected by a decrease in the number of pigs, but also by high imports, especially in manufacturing. Its low competitiveness stemmed from low production efficiency, which in many cases is caused by the low-volume production in slaughterhouses. Quite a large number of processors have a slaughterhouse but with low capacity utilisation. Of the approximately 190 slaughterhouses (in 2012), the top ten slaughterhouses processed almost 50 per cent of slaughter pigs. Pork is still a significant share of the total meat production in the Czech Republic, declining from 2002 to 2013 from 52.8 per cent to 42.5 per cent. Gross production of pork (i.e. the sale of pigs from farms, including self-supply) dropped from 455 thousand tonnes to 242.4 thousand tonnes in carcass weight between 2004 and 2013. Self-supply (domestic slaughter) decreased between 2004 and 2013 by more than 78 per cent to 10.1 thousand tonnes. Pork is currently purchased by consumers primarily in the retail network and few consume meat coming from own production.

During the period 20042014, pork production in the Czech Republic exhibited a downward trend; the exceptions were 2007 and 2013, when there was a year to year increase by 3.2 per cent and 2.6 per cent respectively. The main reason for the increase of production in 2007 was the elimination of certain breeds of pigs due to unfavorable economic developments in the sector. By contrast, in 2013, the annual production growth was influenced also by state aid to farmers to sanitise the breeds. Pig meat production in the Czech Republic declined along with the number of slaughtered animals. In 2003 the Czech Republic slaughtered 4.5 million pigs, in 2008 this fell to 3.7 million heads, and in 2014 to 2.7 million heads, an overall reduction of 40 per cent. While pork production declined in the Czech Republic, consumption was relatively stable. Pork is still a major part of total meat consumption in the Czech Republic, the average share in previous five years (2010-2014) amounted to 53,0 per cent. Annual total meat consumption per capita is around $77 \mathrm{~kg}$, of which pork represents an average of the last ten years of about $41 \mathrm{~kg}$. In the Czech Republic the popularity of pork consumption and its tradition consistently maintains first place among all kinds of meat.

The long-term adverse economic situation in the pig meat sector has caused significant attenuation of the Czech pig stock, the number of pig holders, and thus production. Tracking pig breeding revenues and expenses in the Czech Republic is based on a sample survey of costs and income in agriculture which is regularly monitored by the IAEI. The results of the Survey suggest that both piglets 
rearing and pig fattening have negative long-term profitability in the Czech Republic (Figure 5). The period 2002-2012 returned profits for pig fatteners only in 2005 and at $0.02 \mathrm{EUR} / \mathrm{kg}$ of live weight, as prices of pigs were high, while the prices of inputs (mainly cereals and compound feed) low. On the contrary, in 2007, 2008 and 2010 the profitability of pork production deteriorated sharply. In this period pig prices were low but feed prices and the associated rising costs of pig meat production were high. The return on costs in those years fell below 19 per cent, and the loss amounted to EUR 0.25 0.35 per kilogramme of live weight of fatted pig. At the slaughter weight of about $112 \mathrm{~kg}$ live weight this represented a loss of EUR 28 - 40 per slaughtered animal. Many farms were therefore forced for economic reasons to reduce significantly or end pig production. In particular, this befell holdings without agricultural land, which did not receive any subsidies and were economically dependent on income from sale of animals, which, however, failed to meet the long-term costs.

Figure 5: The costs, prices and return on costs of pigs fattenings in the Czech Republic, 2005-2014.

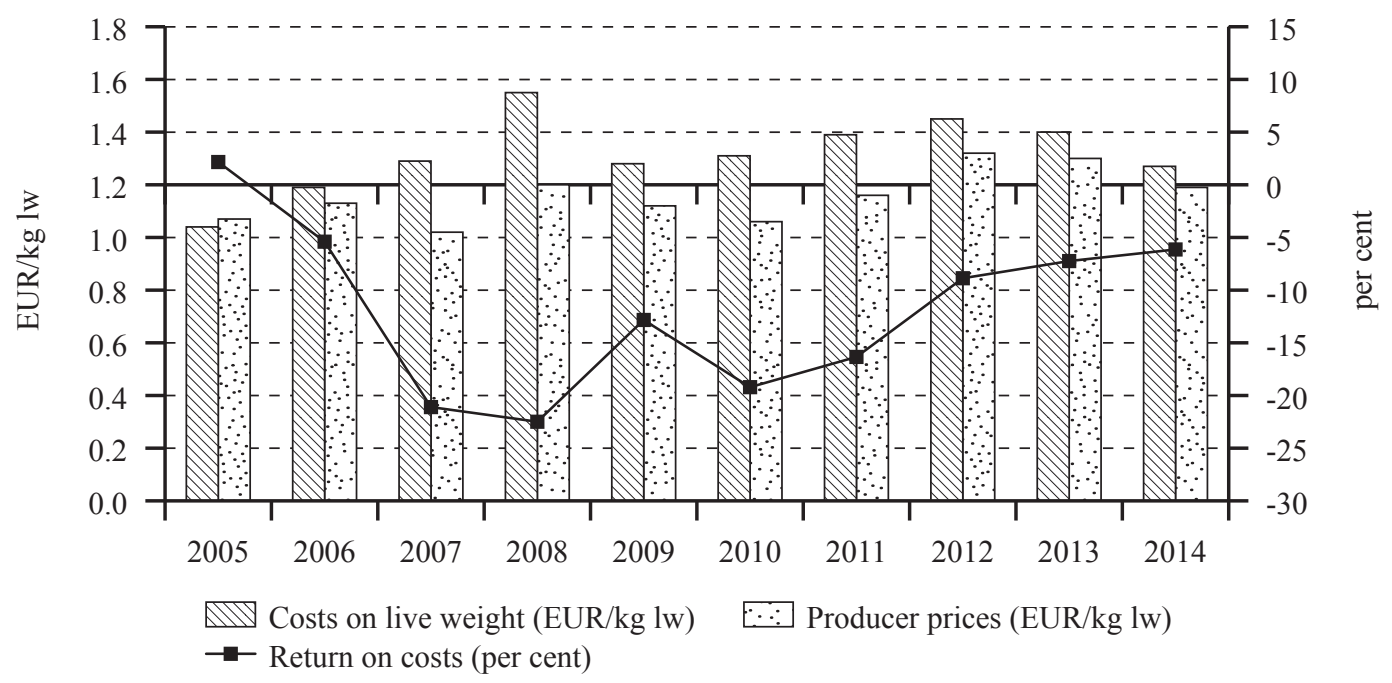

Source: SZIF, IAEI

In the Czech Republic the total cost per slaughtered pig was dependent not only on the results of reproduction and work efficiency in breeding sows, their health, but also on the efficiency of the pre-fattening and fattening of pigs. Cost per weaned piglet, including the costs of pre-fattening pigs, represents approximately 50 per cent of the total cost of the fattened pig, then the remaining 50 per cent accounted for pig fattening phase. The feed represents the most significant cost item in fattening pigs, contributing 65 per cent towards the total cost on average, thus significantly affecting the costs, particularly in 2007.

The prices of pigs in the Czech Republic are based on the development of prices of the commodity in the EU. In particular, after accession to the EU the common market impact on price developments in the country increased significantly. Within the marketisation of the slaughter pigs according to SEUROP in the period 20042014, tover 94 per cent of animals were marketised in the SEU class. From 2004 to 2012, an increasing percentage of pigs were included in the top tier (i.e. the classes S and $\mathrm{E}$, from 9.0 per cent to 12.6 per cent and from 52.5 per cent to 58.8 per cent respectively), while the proportion of animals in the lower classes (UROP) decreased. The highest prices for slaughter pigs' classes SEU (expressed in national currency) were achieved by Czech primary producers in 2005, 2012 and 2013, ranging from 1.41 to $1.73 \mathrm{EUR} / \mathrm{kg}$. In contrast, the lowest prices for agricultural producers were reported in 2007 and 2010 at $1.35 \mathrm{EUR} / \mathrm{kg}$ and $1.40 \mathrm{EUR} / \mathrm{kg}$ respectively. However, because of the exchange rate fluctuation, the lowest euro prices fall into the years 2002-2004. 
In Slovakia it is clear from correlative comparison of slaughter pig prices and their numerous herds that decreasing producer prices were not creating space for maintenance of pig herds (Figures 6 and 7). Decreasing prices were not creating conditions for long-term economic sustainability of pig farming, especially for predominantly large pig farms without agricultural land which did not have the option to cover losses from other sources (for instance from direct payments), and they gradually wentg bankrupt. This negative price development was a crucial factor in the slump in pig herds in Slovakia. Only in 2012 was a significant increase of slaughter pig average prices noted (to the level of 2006) which manifested in an 8.9 per cent year-to-year increase of herds. Steady price development in 2013 and 2014 contributed to pig herd stabilisation in Slovakia.

Figure 6: Processing Prices in Slovakia, 2002-2014.

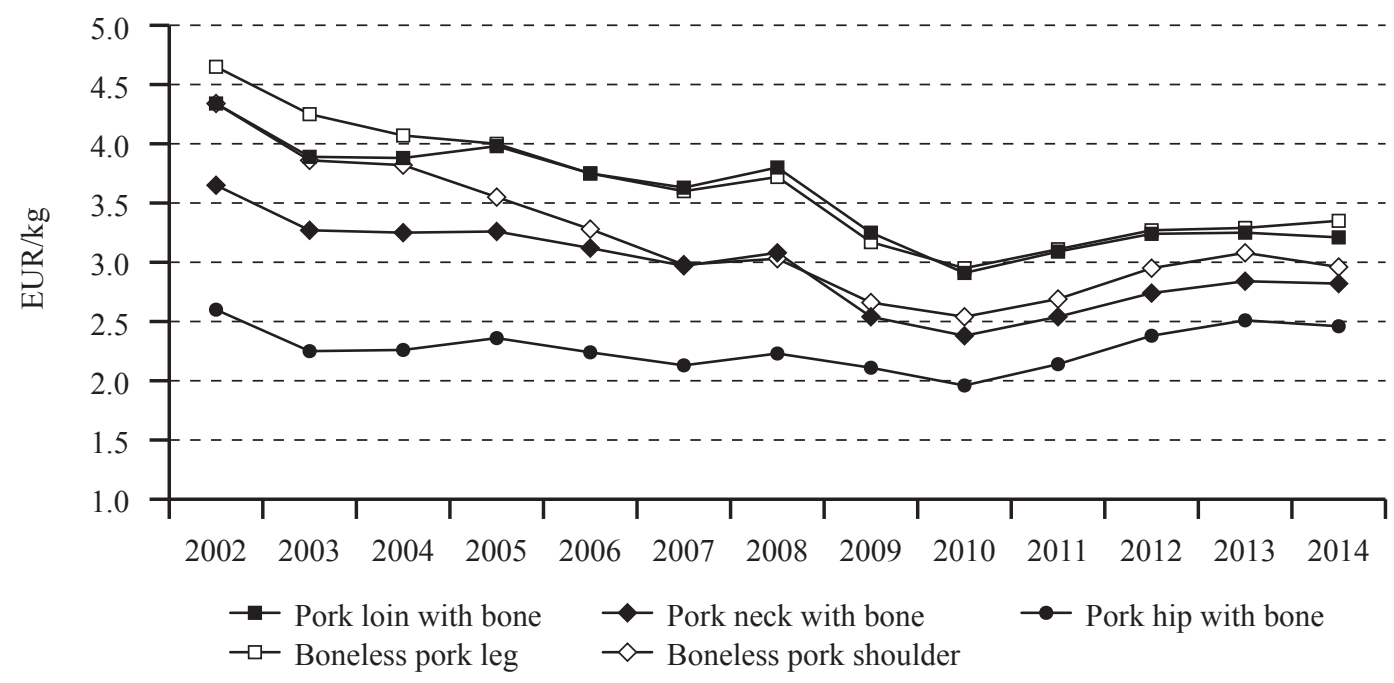

Source: MPRV SR

Figure 7: Consumer Prices in Slovakia, 2002-2014.

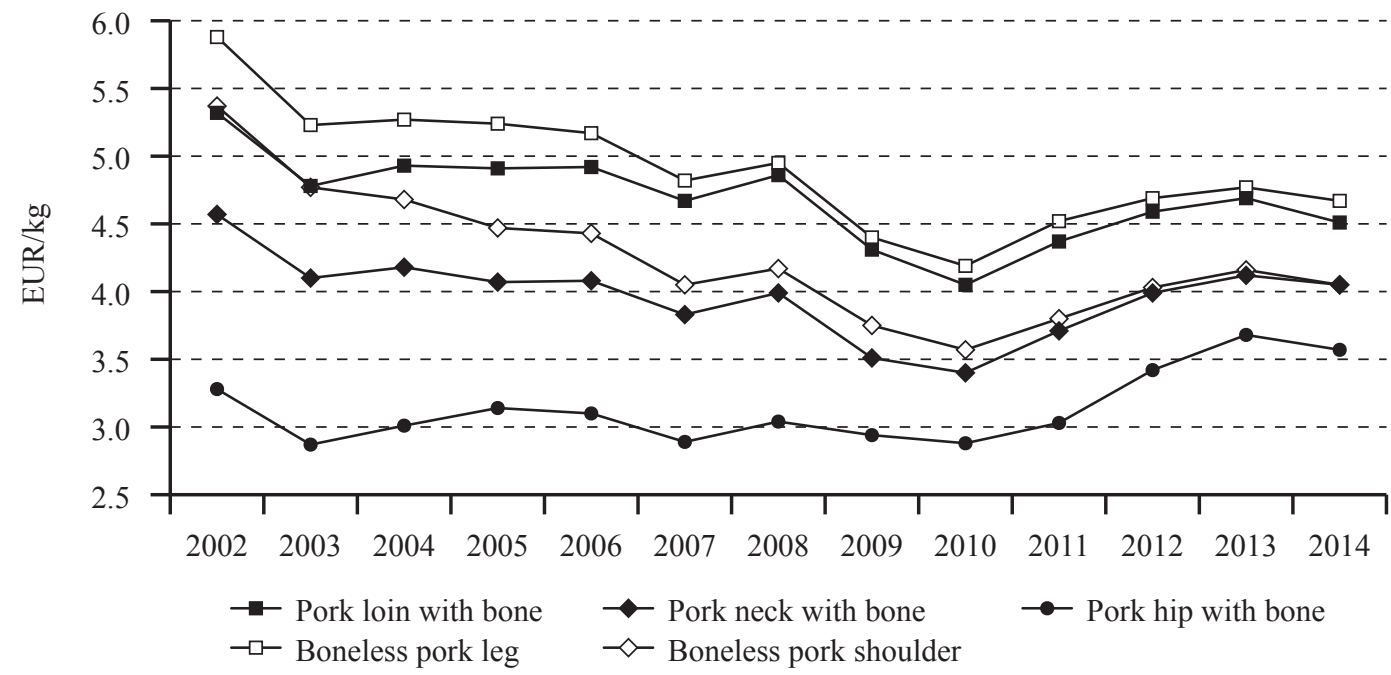

Source: SO SR 
Data of the Research Institute of Agricultural and Food Economics from selected set of enterprises also confirm the economic difficulty with pig farming sustainability in Slovakia during the monitored period. Growth of production input prices (feedstuff and energy prices) were reflected in a gradual increase of the own costs in pig feeding. Through an increase in production effectiveness at the end of the monitored period, unit costs were reduced to the level in 2002. Although data about unit costs amount are acquired only from a selected set of pig keepers in Slovakia, it is evident that since 2003 pig feeding without subvention is persistently lossmaking as market prices did not contrive to cover costs in any year of the monitored period.

Development of slaughter pig farm gate prices was directly influenced by consumer prices as well as by producer prices of registered pork meat varieties. From 2002 to 2010 a declining trend of producer and consumer prices of selected pork meat varieties was noted. Despite this the strong influence of retail chains is demonstrated by a more dynamic decrease of producer prices compared to consumer prices regarding pork leg by 12 percentage points, pork chop and loin end by 9 percentage points, and leg and shoulder by 8 percentage point. Pork consumer prices increased annually to 2013, demonstrated also in increasing producer prices and consecutively also farm gate prices. Contrary to the previous term the price changes dynamic of producers and retailers is significantly more balanced.

\section{Trade}

In Hungary retail trade companies and retail chains are the major market forces. As their market share has grown, so has their bargaining position. They are offering huge sale volumes and at the same time are putting pressure on prices (Kartali, 2009). The retail chains are importing carcasses and meat preparations to offer variety to customers and also to offer very cheap products. They are demanding prices which leave little profit for the sellers, but the meat processors are often forced to accept the offer in order to utilise capacities. Imports, even at dumping prices, are often more competitive than Hungarian production. Processors need to import not only to keep costs down: sometimes there would be an opportunity on the market but there are insufficient quality pigs available. This often happens with bacon pigs. A shortage of heavy slaughtering pigs also makes it difficult to produce some traditional Hungarian products such as special salamis and sausages, and can be the reason for importing meat too. However, cheap imports are usually used for cheap meat preparations for the domestic market (Popp and Potori, 2009).

Hungary exported 533 thousand tonnes of live pigs in 2014, a 25 per cent decrease over the previous year. Live pig exports are mainly directed to the neighbouring countries. Prior to 2004, there were almost no live pig imports, but 53 thousand tonnes were imported into Hungary in 2014. Dutch German, Czech, Polish, Italian and Slovakian pigs appeared in increasing quantities in Hungary in 2014. Because of the decreasing Hungarian pig stock, the slaughterhouses processed imported pork in order to better utilise their capacity. Almost two thirds of pork imports were from Germany and Poland.

In spite of the continually decreasing pig stock, 138 thousand tonnes of pork were exported in 2014, a similar figure to 2013. Hungarian pork exports typically include the chopped bone-in and boneless meat. Pork imports increased significantly in the year of Hungary's accession to the EU, but were still only 60 thousand tonnes. The pork imports decreased from 138 thousand tonnes in 2013 to 134 thousand tonnes in 2014. Overall, Hungary was a net exporter of live pigs and was a net importer of pork. In 2014, 74 per cent of pig meat exports were sold in the EU market. The most important market was Romania, where 33 thousand tonnes of pig meat were delivered from Hungary. Italy was second with 26 thousand tonnes, and was followed by Japanese markets with 20 thousand tonnes. Hungary imports cheaper pork meat categories which are mainly used in the manufacture of products. This is the reason why the pork trade balance remained more positive in value then in volume in spite of the high level of imports. In 2014, the value of exports was EUR 329 million, while that of imports was EUR 257 million (Figure 8). 
Figure 8: International trade in live pigs and pork in Hungary, 2003-2014.

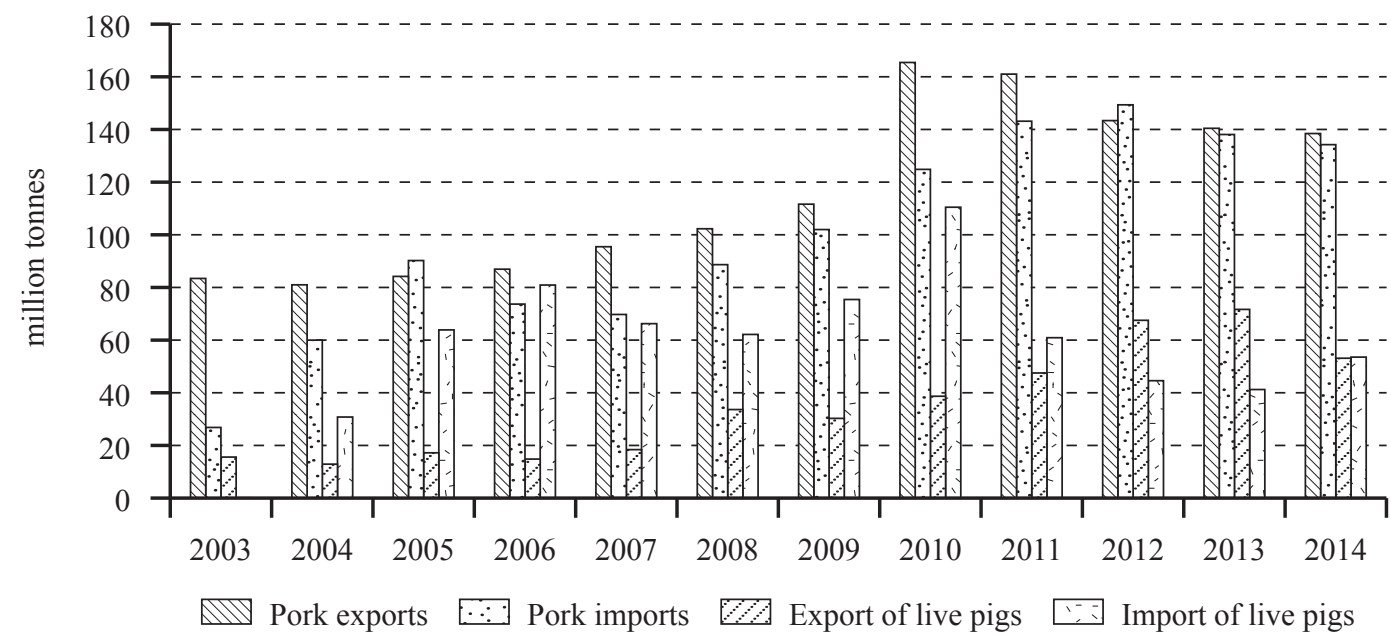

Source: HCSO

Exports of bone-in pork are increasing. Currently, about 75 per cent of the bone-in pork is sold on the domestic market and about 25 per cent is sold abroad, while 20 per cent of the domestic pork supply is imported. The sales of the market-leading organisations vary widely in domestic and foreign markets: 20-60 per cent of the chopped pork is sold domestically while the rest goes abroad. The smaller abattoirs mostly only carry out slaughtering. They sell almost exclusively in the domestic market and sales of half-carcasses account for 80-90 per cent of their total revenue.

The Czech Republic is not self-sufficient in pork production, as gross output is decreasing and is by now far below the level of domestic consumption. The rate of self-sufficiency is therefore in a long-term decline. While in 2004 the Czech Republic was almost self-sufficient in pork (96.9 per cent), by 2012 this figure had dropped to 54.5 per cent. That was the lowest level among all animal production commodities. The main reasons were the low profitability of pig farming and the weak competitiveness of the meat processing industry, which bought pork in increasing volumes from abroad, while it exported its products only minimally. Domestic consumption was therefore covered by the rising volume of imports, which in 2012-2013 exceeded the volume of domestic production. This has been the worst result in the history of the Czech pig production sector and proves that competitiveness throughout the product distribution vertical of the industry continues to decline.

The balance of foreign trade in pigmeat is another indicator that characterised the situation in this sector. Once the Czech Republic joined the EU, the market began to deteriorate especially in terms of foreign trade balance with both pork and live pigs. From 2004 to 2013 the trade balance with pork (including live pigs) worsened by EUR 366 million and amounted to EUR 424 million. Its share accounted for nearly 50 per cent of total agriculture foreign trade (EUR 912 million). In 2004, the Czech Republic showed a 48 thousand tonnes, EUR 82.9 million deficit of pork, and in 2014 there was a decline to 191.2 thousand tonnes and EUR 402.5 million. Although imports and exports grew over the ten-year period at an almost the same annual rate (i.e. 17 per cent and 15 per cent respectively), in terms of volume this represented a significant difference (Figure 9). The most important trade partner for the period 2004 to 2014 was Germany, the origin of more than 45 per cent of purchased pork, followed by Austria, Belgium, Poland and Denmark. In contrast, exports were sent mainly to Slovakia, which accounted for more than 80 per cent of the total export volume. 
The balance of trade in live pigs in the Czech Republic showed self-sufficiency in the past, however, this has changed since 2007. A big decline in domestic sow farms caused farmers focused on fattening pigs to complement their piglets from abroad. From 2004 to 2012 they increased their imports from 6 thousand heads to a record 604 thousand heads. In the years 2013-2014 imports dropped. In the years 2009-2014 piglets comprised nearly 80 per cent of total imports of live pigs. The largest trading partners in terms of imports of live pigs as piglets were the Netherlands and Denmark, and for other categories of pigs (slaughter, breeding), Germany. Exports of live pigs peaked in 2004, in the last three years (2011-2014) it rose slightly to over 250 thousand heads. It consisted mainly of fattening pigs which made up over 77 per cent for the 2004-2014 period. The main customers were Slovakia, Hungary and Germany.

Figure 9: The development of foreign trade with pork and live pigs in the Czech Republic, 2002-2014.
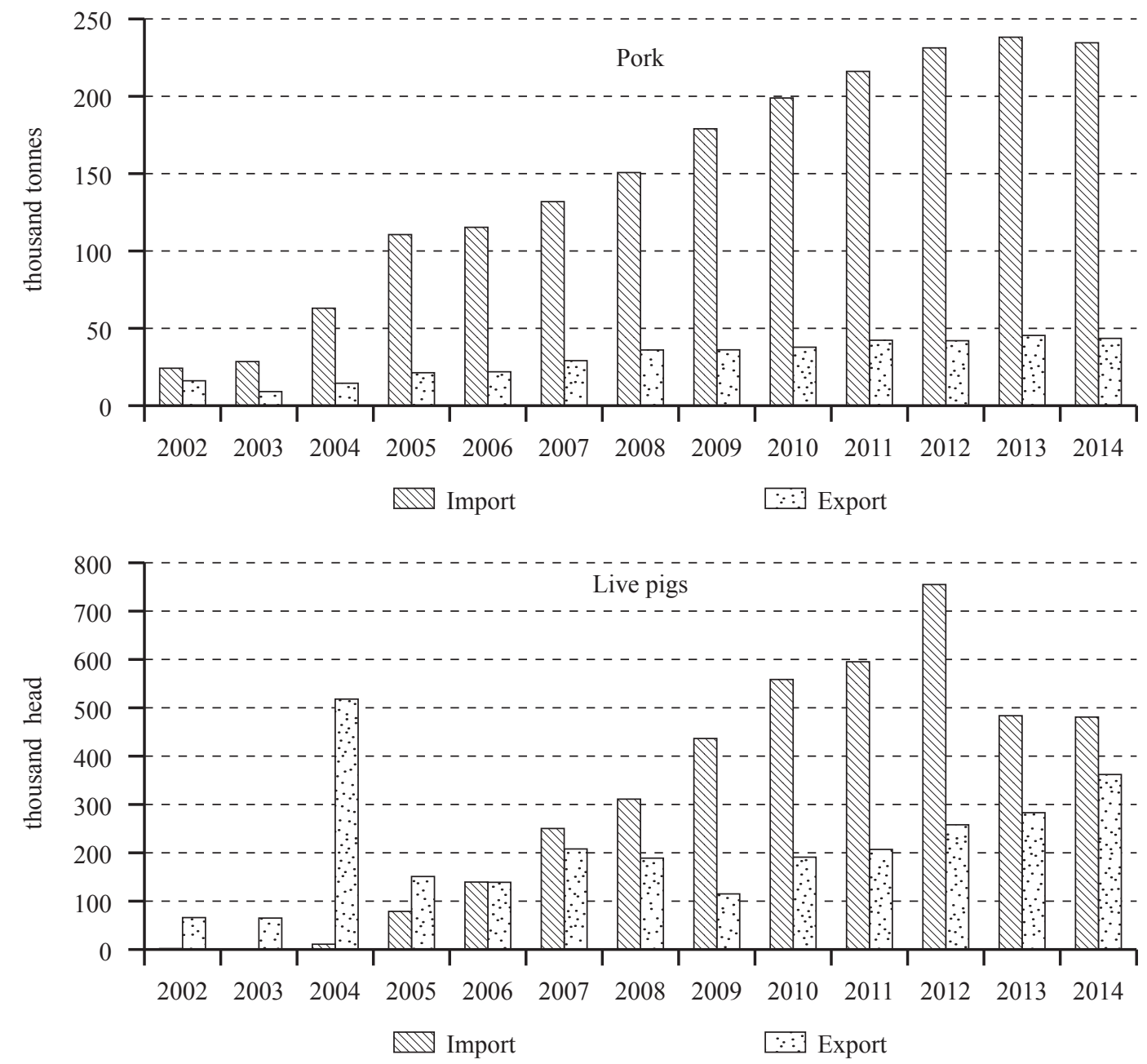

Source: CZSO, IAEI 
Figure 10: The development of foreign trade balance with live pigs and pork in the Czech Republic, 2002-2014.

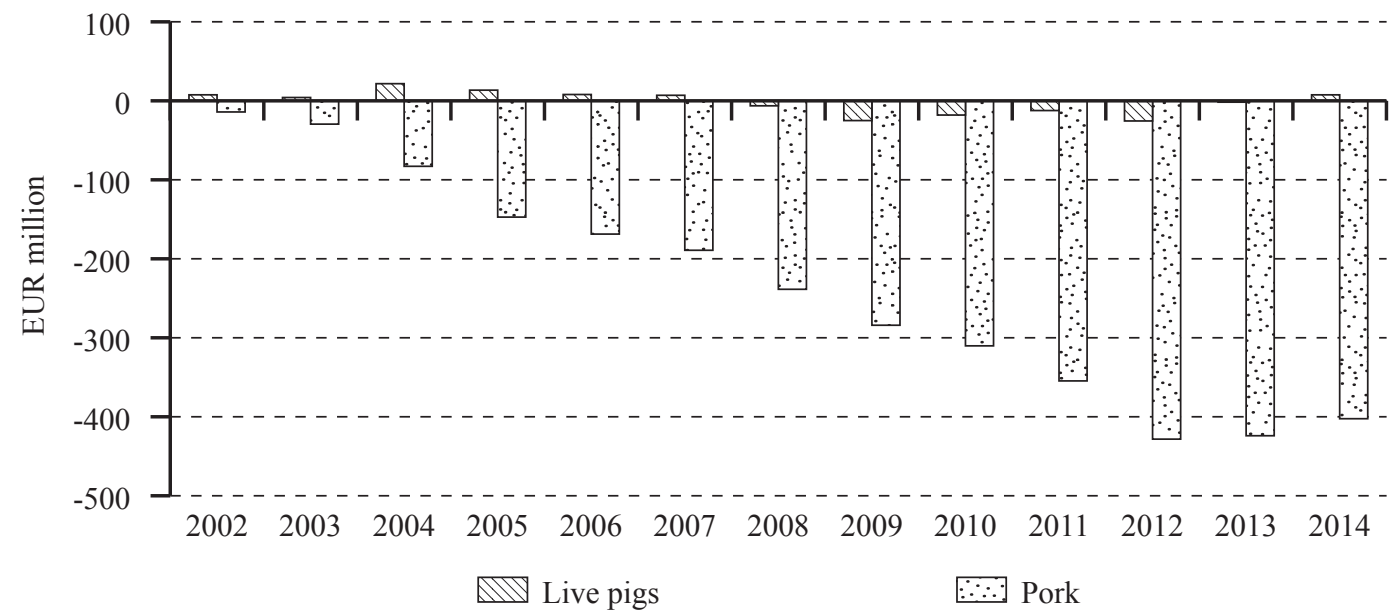

Source: CZSO, IAEI

The development of pig herds directly reflects on the level of slaughter pig sales in Slovakia. While in 2002, at 164 thousand tonnes live weight of slaughter pig sales were recorded, in 2014 just 77.6 thousand tonnes live weight it were sold (Figure 11). At the same time pork consumption level recorded by SO SR was steady, ranging from 30 to 33 kilogrammes per capita. There is a growing need to cover domestic consumption through pork imports so that the development of the Slovak pork market indicators will be balanced.

Figure 11: Development of balance indicators at pig meat market in Slovakia, 2002-2014.

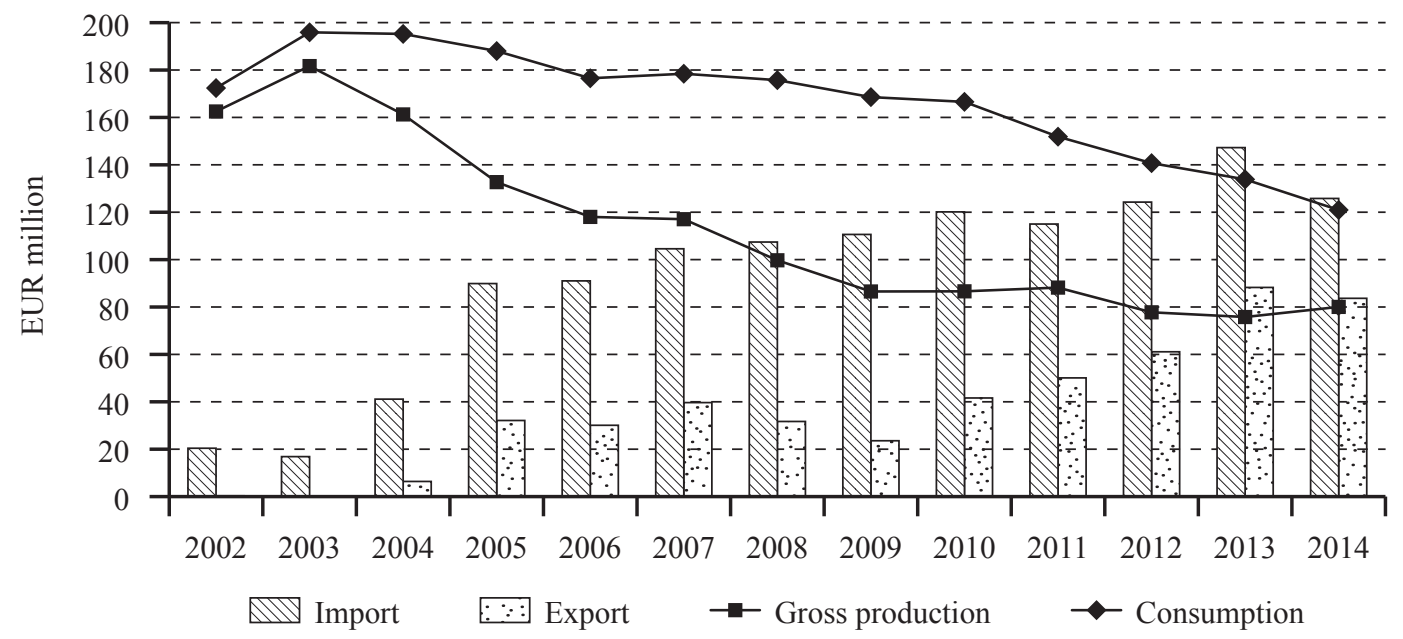

Source: SO SR, NAFC-RIAFE 
It is possible to identify the competitiveness of agricultural and food products that belong to the pork vertical on international markets on the basis of trade indicators. We focused on financial and natural import volume, export and trade balance. The Slovak Republic is a long term net importer of pork from EU Member States. EU accession had the largest impact on the pork sector. While in 2002 Slovakia imported 14.9 thousand tonnes of pork (HS 0203) with a total value EUR 37.4 million, since 2004 imports have increased to 88.8 thousand tonnes with a value of EUR 232.5 million. EU accession simplified entry into foreign markets for Slovak producers, however export volume significantly lag behind imports due to declining domestic production. The result is a constantly deepening negative trade balance and within the commodity structure of Slovak agricultural and food foreign trade, pork is the commodity aggregation with the highest negative balance of trade.

In 2002 the import volume exceeded exports by 14.6 thousand tonnes or EUR 36.6 million. By 2013 it had increased to 70.4 thousand tonnes or EUR 183.7 million. Based on these data there is clear that domestic production has gradually been replaced by cheaper pork imports as the purchase price of slaughter pigs is below the average production costs and they are only increasing the losses of pig keepers that as a final result have led to a dramatic decline in the pig herds in Slovakia. Domestic pig keepers are seeking a way out in the export of live pigs, mainly to Hungary. While in 2004 just EUR 1.5 million of live pigs were exported (live pigs were not exported previously), exports reached EUR 111.4 million in 2013. The level of self-sufficiency of Slovakia is radically decreasing along with a steady domestic consumption level through increasing exports of live animals and it is constantly increasing the need to cover consumption to a greater extent by pork imports. Uncertainty in future development of slaughter pig producer prices means that the Slovak pig keepers restore or widen their breeding through feeding of purchased weaners from abroad which it is demonstrated in terms of significant growth of live animals imports. Despite this, a markedly positive trade balance in live pigs trade was achieved during the last period, but at the expense of an increasing negative balance of trade in pork business.

The National Agricultural and Food Centre - Research Institute of Agricultural and Food Economics (NPPC-VÚEPP) compiles the pork balance in slaughter weight according to the Eurostat methodology. Differences between balance consumption and consumption declared by the SO SR are caused by differing calculation methodologies. Foreign trade in live animals, meat and meat products from domestic sows calculated into slaughter weight is counted in balance in line with Eurostat methodology as SO SR takes into consideration also trade with other types of meat.

During the period 2002-2014 the natural volume of gross domestic production decreased up to 50.7 per cent and balance of domestic consumption by 29.8 per cent. Since 2003 consumption balance indicates a significant declining trend, contrary to consumption declared by SO SR which predominantly relates directly to annual growth of animal amounts and other exported types of meat that are not included in the balance. Considerably progressive development of pork was noted in foreign exchange indicators. Total supply volume and total use increased just by 12.3 per cent and 14.8 per cent respectively. During the past 13 years the share of domestic production in total pork supply in Slovakia fell from 87.7 per cent in 2002 to 38.5 per cent in 2014 . 


\section{Conclusions}

In the three countries, despite the predominating large-scale systems, low efficiency and hence low level of profitability remain in pork production. Compared to the breeders in more developed EU countries (e.g. Denmark, Netherlands) production costs are high due to the lower number of weaned piglets per sow per year, and the cost of fattening pigs are also high due to lower gains and higher feed conversion. Concentration of the meat processing industry is low in comparison with the EU-15 (in the Czech Republic in 2010 there were 195 abattoirs slaughtering pigs, of which the top ten slaughtered more than 50 per cent). This is also reflected in the lower production efficiency. There is a lack of participation of producers and processors in quality systems which are applied in many developed EU countries (eg. Germany, Denmark, Austria etc.) as part of the marketing of domestic and European production of higher quality and added value. In terms of consumer demand, the sector appears to be very stable, it is up to local producers and processors to be able to meet consumer demand from domestic sources.

Increasing the efficiency of the processing industry and the average redemption price for the primary producer is a matter of supplier-customer relations between business entities. The processing industry is cost limited by concentrated retail requirements. Therefore, it is pushed to minimise the purchase price of the raw material. The high surplus EU and the uniform market of EU allows processors to buy cheaper pork from abroad. This displaces domestic producers, who are must look for pork sales abroad. Resolving of supplier-customer relations would both limit the export of live pigs on the one hand and enhance the performance of the processing industry on the other hand.

The Hungarian government has also elaborated a programme for the pig sector which would be one of the cornerstones of rural development. The programme aims to double the pig livestock population (presently 3 million heads) in seven years. To reach this ambitious target the programme states that in the Hungarian pig sector small and middle size as well as large farms should coexist and they should cooperate in order to increase their competitiveness and to facilitate successful rural development. Concerning the pig programme, at the end of August 2012 the government announced Decision No. 1323/2012. This decision states that the development and supporting of livestock production and especially of pig production and the processing industries is a high priority.

There is significant over-capacity in Hungarian slaughtering and processing. Some factories are operating in 100-year-old buildings where enlargement is not possible, and they lack the necessary capital for green field investments. The Bonafarm Group, with a significant pig production background and with processing capacity, can be the first to overcome this problem. The company published a plan to build a new slaughterhouse in Mohács with a slaughtering capacity of one million head (in case of one shift). The new and modern slaughterhouse could work with prices, even in case of contract slaughtering (slaughtering for third parties), that could be lower then the first cost at the small slaughterhouses. If the plan comes to fruition, considerable restructuring and development of the pig chain can be expected.

To enhance the competitiveness of Czech pig farmers it will be necessary to increase the efficiency of pork production by reducing costs at all stages of primary production (from production of piglets to fattening pigs); improve cooperation in product distribution within the stream of primary producers - sales organisation - the processor, i.e. increase the efficiency of the sales organisation; focus on improving marketing (introduction of own-brand quality in the promotion of local food, plus engaging in Q-system) and in other market segments (quality, regional food, animal welfare); increase the efficiency of the domestic processing industry; and to increase the effectiveness of primary producers and processors in the absence of own resources for modernisation, for which it is advisable to engage domestic non-agricultural and foreign capital. 
The MPRV SR has also begun to focus on the negative development in pig breeding in Slovakia. It aims to achieve following basic market indicators in the framework of the "Concept of Development of Agriculture for the years 2013-2020" in pig breeding: to increase the number of sows by 30 thousand units and simultaneously increase their reproductive efficiency to 20-21 piglets per sow; to increase the performance of processing industry in Slovakia at least by 42.5 per cent of current pure pork production, which in absolute terms is a performance increase of 272,9 thousand units or 24 thousand tonnes in carcass weight; and to achieve the average purchase price for primary producers per $1 \mathrm{~kg}$ of body weight, this would cover its own costs. The planned total number would move Slovakia back above the level of self-sufficiency by means of the improved reproductive performance indicators. It is clear though, that the recent development of the market makes such a massive expansion of pig breeding difficult. 


\section{Competitiveness of the milk sector}

VÖNEKI, Éva ${ }^{1}$, MATOSKOVA, Dagmar², BOSKOVA, Iveta ${ }^{3}$ and PÓTI, Gábor ${ }^{1}$

\section{Introduction}

Increasing global demand for dairy products and liberalisation of the markets create new opportunities for the milk sector of the EU. Abolition of the milk quota system in 2015 led to increased competition between the Member States. In this context, we assess and compare the competitiveness of the dairy sectors in Slovakia, the Czech Republic and Hungary. Specifically, we compare the characteristics of the raw milk production and the processing industry; the trade patterns of milk and milk products in the light of developments and expectations on the international markets; the price developments at the different stages of the dairy chain, and the legal and regulatory environment affecting the dairy sector in the three countries. National statistics, international databases and projections are used to compare the main characteristics of the dairy supply chain in the Slovak and Czech Republics and in Hungary and to describe the current and projected developments in the international markets. As results we present information about the factors which influence competitiveness and efficiency at the farm and processing industry levels and the expected effects of the international market processes on the milk market. The studied time period is basically the years from 2003 to 2013. However, in some cases we use different time periods because of data deficiencies or the importance of the latest developments.

\section{Supply side of the dairy chain}

According EC (2014) milk production of the EU-28 reached 148.9 million tonnes in 2013 which represented 21 per cent of the global production. Two thirds of the total milk output of the EU stems from six countries, Germany, France, the United Kingdom, Poland, the Netherlands and Italy. In 2013 , milk production of Slovakia amounted to 0.6 per cent of the total EU-28 milk production. The share was 1.8 per cent in the case of the Czech Republic. Hungary's share of the EU's milk production barely exceeded one percent in 2013. Within the limits of the quota, EU milk production has increased slightly in recent years. The growth has strengthened since 2010, due to the strong export demand, the relatively high raw milk prices and the seasonally favourable weather conditions.

Between 2003 and 2013, the number of dairy cows decreased by 33.2 per cent in Slovakia. The main reasons for this decrease were the increasing import of more competitive foreign milk products, the low profitability of Slovakian milk production, the pan-European milk crisis and the input price increase, as well as the volatility of agrarian markets mainly in connection with extreme weather events which impacted on the prices of grains and feed mixtures. Pursuant to these facts, total Slovakian cow milk production decreased by 18.2 per cent in the monitored period (Table 1).

Research Institute of Agricultural Economics, Budapest, Hungary.

National Agricultural and Food Centre - Research Institute of Agricultural and Food Economics, Bratislava, Slovak Republic.

Institute of Agricultural Economics and Information, Prague, Czech Republic. 
Table 1: Number of dairy cows and raw cow milk production in Slovakia, 2003-2013.

\begin{tabular}{lccccccccccccc}
\hline \multicolumn{1}{c}{ Year } & $\mathbf{2 0 0 3}$ & $\mathbf{2 0 0 4}$ & $\mathbf{2 0 0 5}$ & $\mathbf{2 0 0 6}$ & $\mathbf{2 0 0 7}$ & $\mathbf{2 0 0 8}$ & $\mathbf{2 0 0 9}$ & $\mathbf{2 0 1 0}$ & $\mathbf{2 0 1 1}$ & $\mathbf{2 0 1 2}$ & $\mathbf{2 0 1 3}$ & $\begin{array}{c}\mathbf{2 0 1 3 /} \\
\mathbf{2 0 0 3}\end{array}$ \\
\hline Cows number & 220.5 & 206.0 & 198.5 & 192.5 & 180.6 & 175.5 & 165.9 & 161.3 & 156.1 & 152.4 & 147.4 & 66.8 \\
\hline $\begin{array}{l}\text { Cow milk } \\
\text { production }\end{array}$ & 1,142 & 1,079 & 1,100 & 1,092 & 1,075 & 1,057 & 957 & 918 & 928 & 959 & 934 & 81.8 \\
\hline
\end{tabular}

Source: SO SR, NPPC-VÚEPP

Most milk from Slovak farms is delivered to an approved purchaser. In the quota year 2013/2014, 54 milk purchasers worked in Slovakia (22 marketing producer organisations, 19 processors ${ }^{4}$ and 13 other trade organisations). For farmers it is very important to trade through marketing producer organisations (MPOs). In 2013/1014, MPOs purchased 28.3 per cent of total purchased milk (in 2005/2006 they purchased only 11.6 per cent) in Slovakia. MPOs enable producers to assure adequate contractual terms with processors and trade organisations including retail chains. The main goal of mutual sale is to bargain reasonable prices on easy terms for longer periods.

As to raw milk use on-farm, the processing industry purchases more than 90 per cent of the produced cow milk, while farm animals consume nearly 5 per cent of the milk. The rest is used for direct sale and production of milk products. Until 2009, less than one percent of milk production was used for direct sale. The higher share of direct sale in the period of 2009-2013 (approximately 2.3 per cent) as compared to the previous period was caused mainly by permission for direct sale from the farm gate. The number of farms that produce own milk products in Slovakia is relatively low (28 farms in 2013). At the farm level most raw cow milk is used for marketing milk production. In spite of that, the share of marketing milk has decreased and the share of products with higher value added has increased.

Table 2: Purchase of raw cow milk from producers according to quality classes in Slovakia.

\begin{tabular}{lrrrrrrr}
\hline Description & $\mathbf{2 0 0 3}$ & $\mathbf{2 0 0 9}$ & $\mathbf{2 0 1 0}$ & $\mathbf{2 0 1 1}$ & $\mathbf{2 0 1 2}$ & $\mathbf{2 0 1 3}$ & $\begin{array}{c}\mathbf{2 0 1 3} \\
\mathbf{2 0 0 3}\end{array}$ \\
\hline \multicolumn{7}{c}{ thousand tonnes } \\
\hline Total & 976.5 & 852.4 & 800.0 & 811.5 & 851.3 & 826.6 & per cent \\
\hline Q class & 491.5 & 420.0 & 439.0 & 485.2 & 494.4 & 520.2 & 105,8 \\
\hline I. class & 429.7 & 388.6 & 334.2 & 305.0 & 335.4 & 292.5 & 68,1 \\
\hline Non-standard & 55.2 & 43.9 & 26.8 & 21.4 & 21.5 & 13.9 & 25,2 \\
\hline & \multicolumn{7}{c}{ per cent } \\
\hline Total & 100.0 & 100.0 & 100.0 & 100.0 & 100.0 & 100.0 & - \\
\hline Q class & 50.3 & 49.3 & 54.9 & 59.8 & 58.1 & 62.9 & - \\
\hline I. class & 44.0 & 45.6 & 41.8 & 37.6 & 39.4 & 35.4 & - \\
\hline Non-standard & 5.7 & 5.2 & 3.3 & 2.6 & 2.5 & 1.7 & - \\
\hline
\end{tabular}

Source: MPRV SR, NPPC-VÚEPP

In Slovakia, more than 95 per cent of the purchased milk was (extra) quality or first class. (Table 2). The increase in the share of quality class milk is a positive point. In the last decade, fat content has not changed significantly and it fluctuated around 3.8 per cent (Table 3 ). Protein content has increased from 3.23 per cent in 2003 to 3.37 per cent in 2013.

\footnotetext{
Milk industry enterprises.
} 
Table 3: Quality of raw cow milk according to fat and protein content in Slovakia, 2003-2013.

\begin{tabular}{lccccccccccccc}
\hline \multicolumn{1}{c}{ Description } & $\mathbf{2 0 0 3}$ & $\mathbf{2 0 0 4}$ & $\mathbf{2 0 0 5}$ & $\mathbf{2 0 0 6}$ & $\mathbf{2 0 0 7}$ & $\mathbf{2 0 0 8}$ & $\mathbf{2 0 0 9}$ & $\mathbf{2 0 1 0}$ & $\mathbf{2 0 1 1}$ & $\mathbf{2 0 1 2}$ & $\mathbf{2 0 1 3}$ & $\begin{array}{c}\mathbf{2 0 1 3} \\
\mathbf{2 0 0 3}\end{array}$ \\
\hline Fat & 3.70 & 3.80 & 3.80 & 3.70 & 3.80 & 3.80 & 3.70 & 3.80 & 3.80 & 3.80 & 3.85 & 104.1 \\
\hline Proteins & 3.23 & 3.30 & 3.30 & 3.30 & 3.30 & 3.30 & 3.30 & 3.30 & 3.40 & 3.40 & 3.37 & 104.3 \\
\hline
\end{tabular}

Source: MPRV SR, NPPC-VÚEPP

Since 2003 milk yield per cow has increased in Slovakia (Table 4), mitigated the impact of the decline in the number of dairy cows on total milk production. Milk yield is very significant in terms of production costs per litre of milk and competitiveness in domestic and foreign trade.

Table 4: Milk yield in Slovakia, 2003-2013.

\begin{tabular}{cccccccccccccc}
\hline Year & $\mathbf{2 0 0 3}$ & $\mathbf{2 0 0 4}$ & $\mathbf{2 0 0 5}$ & $\mathbf{2 0 0 6}$ & $\mathbf{2 0 0 7}$ & $\mathbf{2 0 0 8}$ & $\mathbf{2 0 0 9}$ & $\mathbf{2 0 1 0}$ & $\mathbf{2 0 1 1}$ & $\mathbf{2 0 1 2}$ & $\mathbf{2 0 1 3}$ & $\begin{array}{c}\mathbf{2 0 1 3} / \\
\mathbf{2 0 0 3}\end{array}$ \\
\hline Milk yield & 5,180 & 5,236 & 5,542 & 5,670 & 5,951 & 6,025 & 5,770 & 5,692 & 5,946 & 6,296 & 6,334 & 122,3 \\
\hline
\end{tabular}

Source: SO SR, NPPC-VÚEPP

In the Czech Republic, the dairy herd decreased by 18.9 per cent during the period 2003-2013. The main reasons are the low profitability of milk production, the import of foreign milk products frequently linked to multinational character of marketing chains operating on the Czech market, the pan-European milk crisis accompanied by the fall in farm milk prices, the volatility of agrarian markets and profitability of competitive agrarian production (suckler cow herd). Since the milk price has improved in the last two years, the dairy herd started to recover after a long period of decline, increasing by 1 per cent in 2013 (Table 5).

Table 5: Development of dairy cow number and production of cow's milk in the Czech Republic, 2003-2013.

\begin{tabular}{lrrrrrrrrrrrrr}
\multicolumn{1}{c}{} & \multicolumn{1}{c}{ Year } & $\mathbf{2 0 0 3}$ & $\mathbf{2 0 0 4}$ & $\mathbf{2 0 0 5}$ & $\mathbf{2 0 0 6}$ & $\mathbf{2 0 0 7}$ & $\mathbf{2 0 0 8}$ & $\mathbf{2 0 0 9}$ & $\mathbf{2 0 1 0}$ & $\mathbf{2 0 1 1}$ & $\mathbf{2 0 1 2}$ & $\mathbf{2 0 1 3}$ & $\begin{array}{c}\mathbf{2 0 1 3} \\
\mathbf{2 0 0 3}\end{array}$ \\
\hline Cows number & 460 & 433 & 438 & 423 & 410 & 403 & 394 & 378 & 374 & 369 & 373 & 81.1 \\
\hline Production & 2,646 & 2,602 & 2,739 & 2,694 & 2,684 & 2,728 & 2,708 & 2,613 & 2,664 & 2,741 & 2,775 & 104.9 \\
\hline
\end{tabular}

Source: CZSO; IAEI

Milk volume produced in the Czech Republic fluctuated at about 2.7 million $\mathrm{kg}$ because the decreasing dairy herd was accompanied by a noteworthy milk yield increase per cow. The annual milk yield increased during the period 2003 to 2013 by 29.3 per cent and reached 7,644 $\mathrm{kg}$ in 2013 (Table 6). Tthe herd was composed of the Holstein breed (55.1 per cent, with blood share exceeding 50 per cent), the Czech red pied (37.9 per cent) and crossbreds and other breeds ( 7 per cent).

Table 6: Milk yield in the Czech Republic, 2003-2013. 
Out of the total raw milk produced, around 96 per cent is marketed and the rest is used on-farm for feeding. In 2013, 2,725 million $\mathrm{kg}$ of milk were delivered for processing and 0,009 million $\mathrm{kg}$ were marketed at the farm gate, which together accounted for 96.1 per cent of total milk production. Fat content of Czech raw milk has slightly decreased while protein content has not changed significantly between 2003 and 2013 (Table 7).

Table 7: Quality of raw cow milk according to fat and protein content in the Czech Republic, 2003-2013.

\begin{tabular}{lccccccccccccc}
\hline Description & $\mathbf{2 0 0 3}$ & $\mathbf{2 0 0 4}$ & $\mathbf{2 0 0 5}$ & $\mathbf{2 0 0 6}$ & $\mathbf{2 0 0 7}$ & $\mathbf{2 0 0 8}$ & $\mathbf{2 0 0 9}$ & $\mathbf{2 0 1 0}$ & $\mathbf{2 0 1 1}$ & $\mathbf{2 0 1 2}$ & $\mathbf{2 0 1 3}$ & $\begin{array}{c}\mathbf{2 0 1 3 /} \\
\mathbf{2 0 0 3}\end{array}$ \\
\hline Fat & 3.97 & 4.00 & 3.90 & 3.90 & 3.88 & 3.86 & 3.71 & 3.86 & 3.88 & 3.85 & 3.88 & 97.7 \\
\hline Proteins & 3.39 & 3.40 & 3.38 & 3.35 & 3.37 & 3.35 & 3.31 & 3.37 & 3.38 & 3.39 & 3.40 & 100.3 \\
\hline
\end{tabular}

Source: MPRV SR, NPPC-VÚEPP

The number of registered quota holders, which is identical to the number of dairy farmers, has decreased significantly since the registration system was started in the country. While in 2003 there were 2,969 registered dairy farms, in 2013 there remained 2,182 registered dairy farms. As in other EU Member States, in Hungary the dairy cow stock has almost continuously declined in recent years; the figure of 204 thousand dairy cows as of 1 December 2013 is 58 per cent lower than ten years earlier.

The most significant changes were caused by the decreasing level of financial support and falling milk prices after Hungary's accession to the EU. Hungarian milk production declined remarkably, amounting to just 1.76 million tonnes in 2013. However, the stock of dairy cows has slightly increased since 2011, mainly due to the favourable development of the raw milk prices. The yields per cow have been continuously increasing in Hungary, thus since 2011 there has been some growth in production due to the increased number of cows and higher milk yields. Hungary has an average yield of 7,110 kg per cow in 2013, compared to an average of 6,517 kg per cow in the EU-28. Furthermore, the national average is above that of other CEECs including the Czech and Slovak Republics (Table 8).

Table 8: Cow milk production in Hungary, 2003-2013.

thousand heads and tonnes, $\mathrm{kg} / \mathrm{year} / \mathrm{cow}$

\begin{tabular}{lrrrrrrrrrrrr}
\hline \multicolumn{1}{c}{ Year } & $\mathbf{2 0 0 3}$ & $\mathbf{2 0 0 4}$ & $\mathbf{2 0 0 5}$ & $\mathbf{2 0 0 6}$ & $\mathbf{2 0 0 7}$ & $\mathbf{2 0 0 8}$ & $\mathbf{2 0 0 9}$ & $\mathbf{2 0 1 0}$ & $\mathbf{2 0 1 1}$ & $\mathbf{2 0 1 2}$ & $\mathbf{2 0 1 3}$ & $\begin{array}{c}\mathbf{2 0 1 3 /} \\
\mathbf{2 0 0 3}\end{array}$ \\
\hline Dairy cow number & 350 & 253 & 237 & 227 & 226 & 226 & 211 & 193 & 197 & 198 & 204 & 58.3 \\
\hline Production & 2,036 & 1,900 & 1,934 & 1,850 & 1,848 & 1,846 & 1,763 & 1,690 & 1,718 & 1,818 & 1,763 & 86.6 \\
\hline Procurement & 1,669 & 1,590 & 1,519 & 1,448 & 1,448 & 1,425 & 1,407 & 1,322 & 1,308 & 1,398 & 1,351 & 79.9 \\
\hline $\begin{array}{l}\text { Export of raw } \\
\text { milk }\end{array}$ & 11 & 36 & 75 & 123 & 132 & 168 & 177 & 170 & 240 & 267 & 275 & 2,500 \\
\hline Yield & 6,171 & 6,148 & 6,447 & 6,700 & 6,893 & 6,991 & 6,860 & 6,896 & 6,869 & 7,129 & 7,110 & 115.2 \\
\hline
\end{tabular}

Source: HCSO

The relatively weak quality parameters of milk and its low protein and fat contents spoil the competitiveness of processing and cause extra costs compared to Hungary's European competitors (Table 9). 
Table 9: Quality of raw cow milk according to fat and protein content in Hungary, 2003-2013.

\begin{tabular}{lcccccccccccc}
\hline \multicolumn{1}{c}{ Year } & $\mathbf{2 0 0 3}$ & $\mathbf{2 0 0 4}$ & $\mathbf{2 0 0 5}$ & $\mathbf{2 0 0 6}$ & $\mathbf{2 0 0 7}$ & $\mathbf{2 0 0 8}$ & $\mathbf{2 0 0 9}$ & $\mathbf{2 0 1 0}$ & $\mathbf{2 0 1 1}$ & $\mathbf{2 0 1 2}$ & $\mathbf{2 0 1 3}$ & $\begin{array}{c}\mathbf{2 0 1 3 /} \\
\mathbf{2 0 0 3}\end{array}$ \\
\hline Fat & 3.74 & 3.73 & 3.57 & 3.66 & 3.66 & 3.69 & 3.71 & 3.64 & 3.6 & 3.63 & 3.71 & 99.2 \\
\hline Protein & 3.29 & 3.28 & 3.17 & 3.25 & 3.24 & 3.27 & 3.31 & 3.24 & 3.24 & 3.21 & 3.23 & 98.2 \\
\hline
\end{tabular}

Source: HCSO

In Hungary, milk is now produced predominantly by agricultural enterprises with relatively high milk yields and the dairy cattle concentration in Hungarian farms is high compared to other EU Member States (Figure 1). The overwhelming majority of the dairy cow population in Hungary is held by cattle farms with a headcount 100 or more. Beside this, high specialisation and investments in modernisation in recent years are competitive advantages for Hungarian milk production. The hungarian cow herd is highly specialised (predominantly Holstein Friesian and Holstein crossbred). The international comparison of milk production costs demonstrates well that, related to the protein and fat content, milk production is relatively expensive in Hungary. Feeding costs are the biggest item in the cost structure. Although there are notable differences among factories in this cost element, most Hungarian milk producers are at a disadvantage against competitors in respect of feed utilisation and of green fodder use. In addition, expenditure on animal health and losses are also significant (Szajner and Vöneki, 2013).

Figure 1: Structure of cow farms in Hungary, 2013.

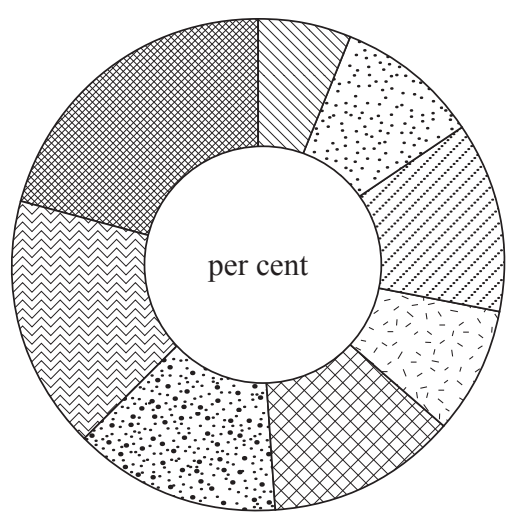

\begin{tabular}{|c|c|}
\hline MV & 1 - 9 heads \\
\hline$\because \because$ & $10-29$ \\
\hline 2 & $30-99$ \\
\hline$\%$ & $100-299$ \\
\hline$\infty$ & $300-499$ \\
\hline$\because 8$ & $500-999$ \\
\hline 図 & $1000-1999$ \\
\hline & $2000 \leq$ \\
\hline
\end{tabular}

Source: HCSO

\section{Demand side of the dairy chain}

According to the EC (2014a) the total amount of milk delivered to the processors in the EU was 141.6 million tonnes in 2013, one percent higher than in the previous year. In the EU-15 delivery has increased, while in the EU-13 less raw milk was delivered to the processors. Strong growth could be observed in countries (Ireland, the United Kingdom and France) where a year before milk output was significantly lower than usual. In addition, the Netherlands, Germany and Poland bought up more milk. The competitiveness of the milk industry, measured by Slovak milk products share on the domestic 
market, decreased from 84.2 per cent in 2004 to 41,1 per cent in 2013. In the monitored period, the total profit/loss of the milk industry was negative, even though two thirds of enterprises were profit-making. Only in 2009 and 2013 was the milk industry as a whole was profit-making (in 2009 following an ultralow milk price). The main reason for the unstable profits is the volatility of milk prices. This situation is also affected by increased import of milk products, because the majority of Slovak consumers have favoured cheaper products from abroad as a consequence of their low purchasing power. In the monitored period, the share of foreign capital in fixed assets increased from 70.6 per cent to 76.1 per cent. In the last decade, the number of enterprises decreased by 17 in Slovakia. In term of enterprise size defined by employee number, one large, seven medium, four small and five micro enterprises closed (Table 10).

Table 10: Number of enterprises in the milk industry of Slovakia, 2003-2012.

\begin{tabular}{lrrrrrrrrrrrrr}
\hline \multicolumn{1}{c}{ Description } & $\mathbf{2 0 0 3}$ & $\mathbf{2 0 0 4}$ & $\mathbf{2 0 0 5}$ & $\mathbf{2 0 0 6}$ & $\mathbf{2 0 0 7}$ & $\mathbf{2 0 0 8}$ & $\mathbf{2 0 0 9}$ & $\mathbf{2 0 1 0}$ & $\mathbf{2 0 1 1}$ & $\mathbf{2 0 1 2}$ & $\mathbf{2 0 1 3}$ & $\begin{array}{r}\mathbf{2 0 1 3} \\
\mathbf{2 0 0 3}\end{array}$ \\
\hline Total number, out of which: & 46 & 41 & 40 & 42 & 45 & 51 & 30 & 31 & 29 & 29 & 29 & 63.0 \\
\hline $\begin{array}{l}\text { According to the number } \\
\text { of employees }\end{array}$ & & & & & & & & & & & & \\
\hline Micro enterprises (0-9) & 8 & 6 & 11 & 13 & 14 & 21 & 5 & 5 & 4 & 4 & 3 & 37.5 \\
\hline Small enterprises (10-49) & 13 & 11 & 6 & 5 & 9 & 10 & 7 & 7 & 7 & 9 & 9 & 69.2 \\
\hline $\begin{array}{l}\text { Medium enterprises } \\
\text { (50-249) }\end{array}$ & 20 & 17 & 16 & 17 & 16 & 14 & 12 & 15 & 14 & 12 & 13 & 65.0 \\
\hline Large enterprises (250-) & 5 & 7 & 7 & 7 & 6 & 6 & 6 & 4 & 4 & 4 & 4 & 80.0 \\
\hline According to profit/loss & & & & & & & & & & & & \\
\hline Profit-making enterprises & 21 & 21 & 18 & 31 & 33 & 31 & 20 & 19 & 20 & 18 & 23 & 109.5 \\
\hline Loss-making enterprises & 25 & 20 & 22 & 11 & 12 & 20 & 10 & 12 & 9 & 11 & 6 & 24.0 \\
\hline According to capital & & & & & & & & & & & \\
\hline With foreign capital & 11 & 11 & 9 & 10 & 8 & 9 & 6 & 7 & 6 & 6 & 6 & 54.5 \\
\hline With domestic capital & 35 & 30 & 31 & 32 & 37 & 42 & 24 & 24 & 23 & 23 & 23 & 65.7 \\
\hline
\end{tabular}

Source: MPRV SR, NPPC-VÚEPP

A decline in the enterprise number implies increasing milk industry concentration which can be expressed through concentration ratio (CR) indicator measured by products production. At the present, concentration of the milk industry is not at a high level in spite of the CR increase. In 2013, the three, five and ten largest enterprises produced 45.7 per cent, 61.7 per cent and 83 per cent of total milk sector products respectively (Table 11).

Table 11: Concentration ratio in the milk industry of Slovakia, 2003-2013.

\begin{tabular}{ccccccccccccc}
\hline $\mathrm{CR}$ & $\mathbf{2 0 0 3}$ & $\mathbf{2 0 0 4}$ & $\mathbf{2 0 0 5}$ & $\mathbf{2 0 0 6}$ & $\mathbf{2 0 0 7}$ & $\mathbf{2 0 0 8}$ & $\mathbf{2 0 0 9}$ & $\mathbf{2 0 1 0}$ & $\mathbf{2 0 1 1}$ & $\mathbf{2 0 1 2}$ & $\mathbf{2 0 1 3}$ & $\begin{array}{c}\mathbf{2 0 1 3 /} \\
\mathbf{2 0 0 3}\end{array}$ \\
\hline $\mathrm{CR}_{3}$ & 30.1 & 35.6 & 37.3 & 30.7 & 39.8 & 39,6 & 42,1 & 44,1 & 43,5 & 45,3 & 45,7 & -8.7 \\
$\mathrm{CR}_{5}$ & 41.0 & 48.2 & 51.2 & 46.6 & 54.2 & 53,3 & 56,3 & 58,1 & 58,2 & 61,7 & 61,7 & -7.0 \\
\hline $\mathrm{CR}_{10}$ & 63.0 & 71.0 & 73.4 & 71.4 & 75.2 & 75,8 & 80,2 & 79,0 & 79,3 & 84,0 & 83,0 & -2.9 \\
\hline
\end{tabular}

a) Change in percentage points; concentration is calculated from data on production in financial expression.

Source: MPRV SR, NPPC-VÚEPP

From the total milk balance (Table 12) results, the milk purchase from farmers fell by 15,8 per cent and supply on the domestic market increased by more than one third as a consequence of EU market liberalisation and a sixfold increase in imports. Supply was increased in accordance with demand, but the export growth rate ( +86.2 per cent) significantly fell behind the import growth rate $(+500.8$ per cent $)$. 
Table 12: Balance of purchased cow milk in Slovakia, 2003-2013.

\begin{tabular}{|c|c|c|c|c|c|c|c|c|c|c|c|c|}
\hline Indicator & 2003 & 2004 & 2005 & 2006 & 2007 & 2008 & 2009 & 2010 & 2011 & 2012 & 2013 & $\begin{array}{l}2013 / \\
2003^{a)}\end{array}$ \\
\hline $\begin{array}{l}\text { Beginning } \\
\text { stocks }\end{array}$ & 36.5 & 20.0 & 18.9 & 17.6 & 27.7 & 32.7 & 39.5 & 26.0 & 19.2 & 27.5 & 22.9 & 62.8 \\
\hline $\begin{array}{l}\text { Milk } \\
\text { purchase } \\
\text { from } \\
\text { farmers }\end{array}$ & $1,008.2$ & 950.5 & 974.5 & 970.1 & 973.6 & 955.0 & 864.1 & 822.0 & 833.2 & 872.3 & 849.1 & 84.2 \\
\hline Import & 105.1 & 140.2 & 301.3 & 351.2 & 412.8 & 447.3 & 455.8 & 615.5 & 525.3 & 507.3 & 631.5 & 600.8 \\
\hline Supply & $1,149.8$ & $1,110.7$ & $1,294.7$ & $1,388.9$ & $1,414.0$ & $1,435.0$ & $1,359.4$ & $1,463.5$ & $1,377.8$ & 1407.0 & 1503.6 & 130.8 \\
\hline Export & 319.5 & 340.3 & 482.2 & 515.0 & 550.2 & 589.7 & 483.8 & 546.6 & 534.9 & 526.9 & 594.8 & 186.2 \\
\hline $\begin{array}{l}\text { Domestic } \\
\text { consump- } \\
\text { tion }\end{array}$ & 810.3 & 751.5 & 794.9 & 796.2 & 831.1 & 805.8 & 849.6 & 897.7 & 815.4 & 857.2 & 887.4 & 109.5 \\
\hline Demand & $1,129.8$ & $1,091.8$ & $1,277.1$ & $1,311.2$ & $1,381.3$ & $1,395.5$ & $1,333.4$ & $1,444.3$ & $1,350.3$ & 1384.1 & 1482.1 & 131.2 \\
\hline $\begin{array}{l}\text { Ending } \\
\text { stocks }\end{array}$ & 20.0 & 18.9 & 17.6 & 27.7 & 32.7 & 39.5 & 26.0 & 19.2 & 27.5 & 22.9 & 21.4 & 107.1 \\
\hline $\begin{array}{l}\text { Self-suffi- } \\
\text { ciency } \\
\text { ( per cent) }\end{array}$ & 124.4 & 126.5 & 122.6 & 121.8 & 117.1 & 118.5 & 101.7 & 91.6 & 102.2 & 101.8 & 95.7 & -28.7 \\
\hline
\end{tabular}

a) Change in percentage points; import and export of milk and milk products are calculated per liquid milk.

Source: SO SR, NPPC-VÚEPP

Since 2003, Slovakia's milk self-sufficiency has significantly decreased. Absolute self-sufficiency (100 per cent) was achieved in 2012 and in 2013 only 95.7 per cent self-sufficiency was achieved. If the downward trend in the number of the milking cows does not stop, eventually milk yield growth rate will not compensate for the decline in the number of milking cows, and in the future Slovakia will be obliged to import more milk products from abroad.

In the Czech Republic, around 97 per cent to 98 per cent of milk purchased is of first or quality class (Table 13). Protein content has not changed much over the last 11 years, being usually between 3.37 and 3.40 per cent on average. The fat component decreased slightly over the years, which is probably to attributable to the significant yield increase. However, both protein and fat components reached very good standards.

Table 13: Purchase of raw cow milk from producers according to quality classes in the Czech Republic, 2003-2013.

housand tonnes

\begin{tabular}{lrrrrrrrrrrrr}
\hline \multicolumn{1}{c}{ Indicator } & $\mathbf{2 0 0 3}$ & $\mathbf{2 0 0 4}$ & $\mathbf{2 0 0 5}$ & $\mathbf{2 0 0 6}$ & $\mathbf{2 0 0 7}$ & $\mathbf{2 0 0 8}$ & $\mathbf{2 0 0 9}$ & $\mathbf{2 0 1 0}$ & $\mathbf{2 0 1 1}$ & $\mathbf{2 0 1 2}$ & $\mathbf{2 0 1 3}$ & $\begin{array}{c}\mathbf{2 0 1 3} / \\
\mathbf{2 0 0 3}\end{array}$ \\
\hline Purchase & 2,599 & 2,563 & 2,543 & 2,393 & 2,454 & 2,433 & 2,354 & 2,312 & 2,366 & 2,446 & 2,382 & 91.7 \\
\hline $\begin{array}{l}\text { of which } \\
\begin{array}{l}\text { 1st and } \\
\text { higher class }\end{array}\end{array}$ & 2,554 & 2,532 & 2,509 & 2,351 & 2,419 & 2,400 & 2,318 & 2,259 & 2,298 & 2,382 & 2,322 & 90.9 \\
\hline \begin{tabular}{l} 
Nonstandard \\
\hline
\end{tabular} & 45 & 31 & 34 & 41 & 35 & 33 & 35 & 53 & 68 & 64 & 60 & 133.3 \\
\hline
\end{tabular}

Source: MZe; IAEI 
As regards organisations of primary dairy farmers, after their progressive increase and consolidation, their number and volume of milk marketed seem to have more or less stabilised in recent years (Tables 14 and 15). Early information indicates 14 producers' organisations in 2000 and the next known figure indicates 25 organisations in 2005. A jump to 37 organizations in 2006 is related to a revised registration system enforced in 2005. Marketing cooperatives are the most common form but not the only ones by far. Limited liability companies are also possible. In the dairy industry, the structural shift shows three main effects. Firstly, the decrease in the processing units on the domestic territory, secondly, the inclusion of German processing plants into the processing network, and finally, the entry of foreign capital investments into the domestic industry.

The number of processing units has declined substantially during last 20 years. In the last ten years the economics of the processing industry still suffered from low capacity utilisation, and it was (and is still) burdened by previous investments needed to meet the EU standards. Thus the dairy processors have to face three streams of economic pressure. The internal one: their position is made difficult by increasing pressure on the downstream market and permanent pressure from the farm level. On the downstream market, the growing competition in milk product sales generally, and the policy of retail chains operating on the domestic market, push down the prices of milk products. The dairy processors come to be highly dependent on the policy of the marketing chains. The figures of the annual retail research Shopping Monitor, compiled by the companies Income Research and by GfK, document the progress of retail chains on retail sales. In 2010 already 80 per cent of domestic consumers purchased milk products in hypermarkets, supermarkets and/or discount stores, while the share in 2000 was 60 per cent. On the other side, the tight economics of milk production at the farm level drives the farmers to improve their economic results by bargaining the milk price.

Table 14: Production and processing structure in the Czech Republic, 2005-2011.

\begin{tabular}{lcrrrrrrrr}
\hline \multicolumn{1}{c}{ Indicator } & Unit & $\mathbf{2 0 0 5}$ & $\mathbf{2 0 0 6}$ & $\mathbf{2 0 0 7}$ & $\mathbf{2 0 0 8}$ & $\mathbf{2 0 0 9}$ & $\mathbf{2 0 1 0}$ & $\mathbf{2 0 1 1}$ & $\begin{array}{r}\mathbf{2 0 1 1 /} \\
\mathbf{2 0 0 5}\end{array}$ \\
\hline Dairy farms & no. & 2,969 & 2,871 & 2,562 & 2,571 & 2,493 & 2,344 & 2,182 & 73.5 \\
\hline of that organised & no. & 1,071 & 1,212 & 1,212 & 1,210 & 1,268 & 1,217 & 1,147 & 107.1 \\
\hline of that organised & per cent & 36 & 42 & 47 & 47 & 51 & 52 & 53 & 147.2 \\
\hline of that in top 3 organisations & per cent & 16 & 16 & 15 & 14 & 15 & 15 & 14 & 87.5 \\
\hline Dairy farmers organisations & no. & 25 & 37 & 42 & 41 & 42 & 37 & 39 & 156.0 \\
\hline Dairies & no. & 48 & 49 & 41 & 38 & 38 & 38 & 39 & 81.3 \\
\hline
\end{tabular}

Source: SZIF, IAEI

The consequence of such pressure from both sides, combined with the internal economics, is the withdrawal of weak processors from the market. In 2010 there were only 35 per cent of the number of dairy plants that operated in 1989 . However, the reduction process seems to have been suspended since 2007. The market pressure excluded the less effective players but attracted new effective ones. For this reason, two German dairy plants located close to the Czech border became a permanent component of the processing network of the Czech Republic. Only a negligible share of milk processed abroad was processed in Italy and other close countries. Other agents who supported the domestic processing industry and thus the domestic farmers are foreign capital investors. The main foreign dairy companies operating on the domestic market are the Lactalis group, Bongrain S.A., the Bell group and Sachsenmilk Leppersdorf GmbH. 
Table 15: Production of selected milk products in the Czech milk industry, 2003-2013.

\begin{tabular}{lrrrrrrrrrrrrr}
\multicolumn{1}{c}{ Description } & $\mathbf{2 0 0 3}$ & $\mathbf{2 0 0 4}$ & $\mathbf{2 0 0 5}$ & $\mathbf{2 0 0 6}$ & $\mathbf{2 0 0 7}$ & $\mathbf{2 0 0 8}$ & $\mathbf{2 0 0 9}$ & $\mathbf{2 0 1 0}$ & $\mathbf{2 0 1 1}$ & $\mathbf{2 0 1 2}$ & $\mathbf{2 0 1 3}$ & $\begin{array}{r}\mathbf{2 0 1 3} \\
\mathbf{2 0 0 3}\end{array}$ \\
\hline Drinking milk total & 480.0 & 503.1 & 572.7 & 593.6 & 604.6 & 644.1 & 663.4 & 620.7 & 626.3 & 601.6 & 631.7 & 131.6 \\
\hline Natural cheeses & 94.4 & 94.4 & 91.7 & 88.1 & 85.9 & 81.4 & 81.2 & 81.0 & 79.5 & 80.7 & 84.8 & 89.8 \\
\hline Processed cheeses & 19.9 & 19.9 & 20.0 & 18.9 & 19.3 & 17.3 & 16.9 & 15.1 & 14.1 & 15.0 & 17.0 & 85.4 \\
\hline Creams & 11.3 & 49.8 & 53.8 & 42.4 & 43.2 & 45.6 & 50.1 & 51.1 & 46.8 & 46.5 & 49.9 & 441.6 \\
\hline $\begin{array}{l}\text { Fermented milk } \\
\text { products }\end{array}$ & 121.4 & 127.6 & 138.8 & 164.6 & 186.0 & 177.4 & 196.2 & 179.6 & 172.9 & 167.7 & 175.5 & 144.6 \\
\hline Butter & 59.1 & 59.4 & 49.1 & 52.1 & 51.3 & 48.6 & 45.8 & 40.7 & 39.3 & 38.9 & 38.0 & 64.3 \\
\hline Milk powder & 63.5 & 53.2 & 51.0 & 36.1 & 38.3 & 39.3 & 31.1 & 26.9 & 29.1 & 30.0 & 31.5 & 49.6 \\
\hline
\end{tabular}

Source: MZe, IAEI

In Hungary, the dairy sector accounted for 9.9 per cent of the food industry's production in 2013, a decrease of 16.9 per cent since 2008. In the last decade, the amount of milk delivered to the processors and the output of dairy products has decreased continuously (Table 16). In 2013 the total raw milk collected by the Hungarian processing units fell by 3 per cent. Between 2003 and 2013 the production of liquid milk declined by 26 per cent, that of butter by 21 per cent and that of cheese and curd by 35 per cent. Only the production of fermented milk products has not decreased in this period.

Table 16: Processing of dairy products in Hungary, 2003-2013.

thousand tonnes

\begin{tabular}{lrrrrrrrrrrrrr}
\hline \multicolumn{1}{c}{ Indicator } & $\mathbf{2 0 0 3}$ & $\mathbf{2 0 0 4}$ & $\mathbf{2 0 0 5}$ & $\mathbf{2 0 0 6}$ & $\mathbf{2 0 0 7}$ & $\mathbf{2 0 0 8}$ & $\mathbf{2 0 0 9}$ & $\mathbf{2 0 1 0}$ & $\mathbf{2 0 1 1}$ & $\mathbf{2 0 1 2}$ & $\mathbf{2 0 1 3}$ & $\begin{array}{r}\mathbf{2 0 1 3} \\
\mathbf{2 0 0 3}\end{array}$ \\
\hline Delivery of raw milk & 1,683 & 1,637 & 1,564 & 1,491 & 1,491 & 1,468 & 1,407 & 1,322 & 1,308 & 1,398 & 1,364 & 81.0 \\
\hline & & \multicolumn{7}{c}{ Production of milk products } \\
\hline Drinking milk & 562.9 & 586.0 & 559.0 & 503.0 & 526.0 & 415.0 & 387.0 & 361.5 & 345.3 & 394.0 & 414.6 & 73.7 \\
\hline Fermented products & 147.2 & 156.3 & 152.0 & 147.0 & 156.0 & 153.0 & 169.0 & 168.6 & 151.7 & 152.8 & 147.2 & 100.0 \\
\hline Butter & 12.0 & 9.9 & 10,7 & 8.4 & 8.0 & 8.1 & 8.4 & 10.5 & 8.8 & 8.8 & 9.5 & 79.2 \\
\hline Cheese & 110.3 & 110.0 & 103.0 & 93.0 & 72.0 & 72.9 & 74.9 & 72.0 & 65.0 & 72.2 & 71.4 & 64.7 \\
\hline
\end{tabular}

Source: HCSO

The high cost ratio of milk processors and their lag in economic efficiency have resulted in a significant drop in competitiveness. While Hungarian milk production is characterised by increasing concentration, there has been an opposite trend in the structure of milk processing. The number of processing plants has increased continuously since 2009 while average procurement has declined (Figure 2). 
Figure 2: Number of processors and average procurement in Hungary, 2003-2012.

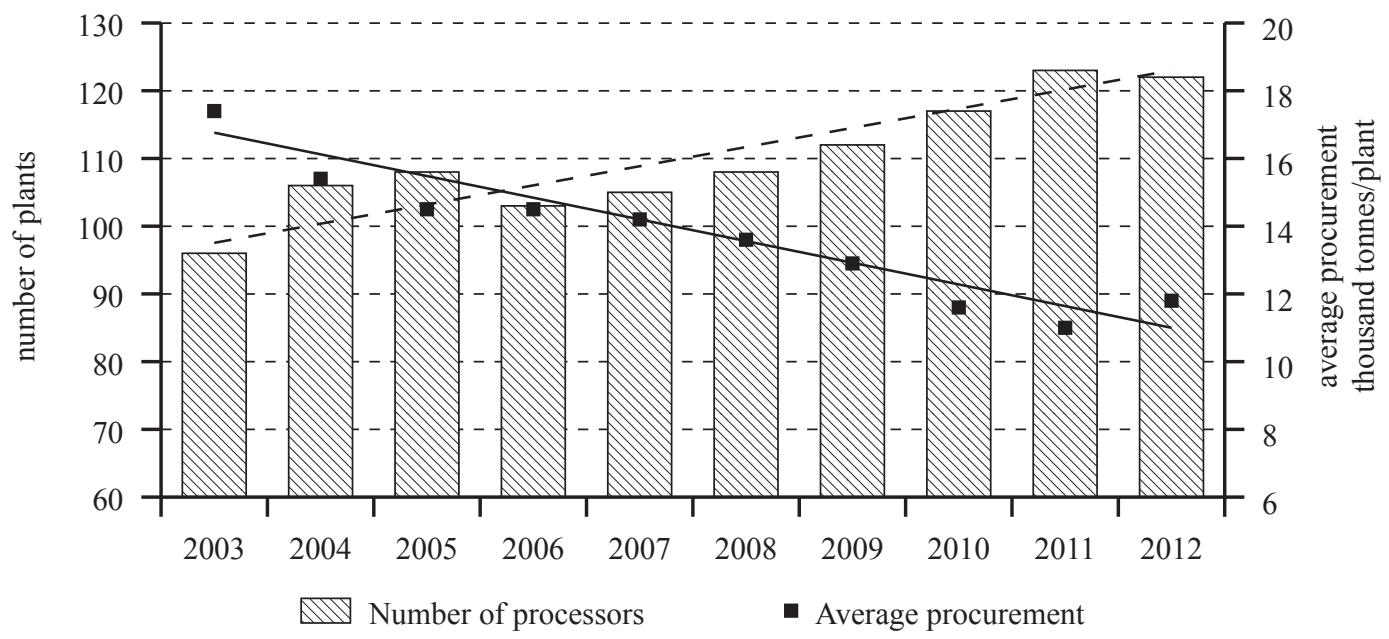

Source: HCSO

Still concentration is relatively high in the Hungarian milk processing sector. In terms of turnover, the top five dairy enterprises had a market share of 55 per cent in 2012. The increased number of very small processors can be explained by the growing importance of direct sales of milk and milk products. Both the number of the profitable enterprises and the number of processors in foreign ownership have decreased in recent years (Table 17). There is only one important processing company owned by the milk producers in Hungary. While there have been remarkable investments made in production in the past five years, the processing industry - except for a few examples - has lagged behind. The most serious disadvantage though, in comparison with the more developed EU Member States, is the weak solvency of the consumers and the drawback stemming from the economy of scale.

Table 17: Description of milk processors in Hungary, 2003-2012.

\begin{tabular}{lrrrrrrrrrrrrr}
\hline \multicolumn{1}{c}{ Indicator } & $\mathbf{2 0 0 3}$ & $\mathbf{2 0 0 4}$ & $\mathbf{2 0 0 5}$ & $\mathbf{2 0 0 6}$ & $\mathbf{2 0 0 7}$ & $\mathbf{2 0 0 8}$ & $\mathbf{2 0 0 9}$ & $\mathbf{2 0 1 0}$ & $\mathbf{2 0 1 1}$ & $\mathbf{2 0 1 2}$ & $\mathbf{2 0 1 2}$ & $\begin{array}{c}\mathbf{2 0 1 2} / \\
\mathbf{2 0 0 3}\end{array}$ \\
\hline $\begin{array}{l}\text { Number of } \\
\text { enterprises }\end{array}$ & 96 & 106 & 108 & 103 & 105 & 108 & 112 & 117 & 123 & 122 & 122 & 127,1 \\
\hline$\quad$ micro & 50 & 61 & 60 & 60 & 61 & 63 & 68 & 74 & 81 & 79 & 79 & 158 \\
\hline \multicolumn{1}{c}{ small } & 14 & 14 & 18 & 16 & 18 & 18 & 17 & 18 & 19 & 17 & 17 & 121,4 \\
\hline$\quad$ middle & 22 & 23 & 21 & 18 & 18 & 20 & 21 & 19 & 17 & 19 & 19 & 86,4 \\
\hline$\quad$ large & 10 & 8 & 9 & 9 & 8 & 7 & 6 & 6 & 6 & 7 & 7 & 70 \\
\hline $\begin{array}{l}\text { Profitable } \\
\text { enterprises }\end{array}$ & 53 & 62 & 46 & 60 & 59 & 54 & 65 & 61 & 59 & 59 & 59 & 111,3 \\
\hline $\begin{array}{l}\text { Enterprises in } \\
\text { foreign owner- } \\
\text { ship }\end{array}$ & 15 & 17 & 14 & 16 & 17 & 13 & 14 & 11 & 11 & 9 & 9 & 60 \\
\hline CR3 & 40,3 & 47,7 & 46,8 & 53,9 & 49,4 & 47,5 & 45,9 & 44,7 & 41,9 & 36,8 & 36,8 & 91,3 \\
\hline CR5 & 55,5 & 63,7 & 62,2 & 65,9 & 62,7 & 60,9 & 59,4 & 60 & 58,4 & 55 & 55 & 99,1 \\
\hline CR10 & 77,2 & 79,4 & 79,1 & 81,4 & 79,1 & 79,6 & 77,8 & 78,3 & 79,1 & 77,6 & 77,6 & 100,5 \\
\hline
\end{tabular}

Source: National Tax and Customs Administration of Hungary (NAV) 


\section{Milk and dairy prices}

Farm milk price is very important for ensuring, profit making and consequent investing in modern technologies, superior genetic material and purchase of good quality fodder. In 2009, as compared to the previous year, the milk price in Slovakia fell significantly as a consequence of the milk crisis, and also in 2013 (extra) quality and first class milk did not command the 2008 price level (Table 18).

Table 18: Farm price of raw cow milk in Slovakia according to quality, 2003-2013.

\begin{tabular}{lccccccccccccc}
\hline Description & $\mathbf{2 0 0 3}$ & $\mathbf{2 0 0 4}$ & $\mathbf{2 0 0 5}$ & $\mathbf{2 0 0 6}$ & $\mathbf{2 0 0 7}$ & $\mathbf{2 0 0 8}$ & $\mathbf{2 0 0 9}$ & $\mathbf{2 0 1 0}$ & $\mathbf{2 0 1 1}$ & $\mathbf{2 0 1 2}$ & $\mathbf{2 0 1 3}$ & $\begin{array}{c}\mathbf{2 0 1 3} \\
\mathbf{2 0 0 3}\end{array}$ \\
\hline Average price & 29.70 & 30.44 & 31.47 & 30.90 & 32.36 & 33.76 & 20.82 & 27.24 & 31.62 & 29.46 & 32.65 & 109.9 \\
\hline Q class & 30.37 & 30.94 & 32.13 & 31.50 & 32.83 & 34.09 & 21.30 & 27.50 & 31.90 & 29.72 & 32.89 & 108.3 \\
\hline I class & 30.00 & 30.74 & 31.73 & 31.17 & 32.70 & 34.29 & 20.85 & 27.41 & 31.64 & 29.48 & 32.59 & 108.6 \\
\hline Non standard & 21.61 & 21.87 & 22.90 & 23.17 & 24.90 & 27.15 & 15.88 & 20.84 & 25.22 & 23.32 & 25.41 & 117.6 \\
\hline
\end{tabular}

Source: MPRV SR, SO SR, NPPC-VÚEPP

As compared 2003 and 2013, the processor and consumer prices of the majority of milk products are increasing in Slovakia. However, the prices of selected milk products fell in 2009 as compared to the previous year following the milk crisis (Table 19).

Table 19: Processor prices (excluding VAT) and consumer prices of selected milk products (including VAT) in Slovakia, 2003-2013.

\begin{tabular}{|c|c|c|c|c|c|c|c|c|c|c|c|c|}
\hline & 2003 & 2004 & 2005 & 2006 & 2007 & 2008 & 2009 & 2010 & 2011 & 2012 & 2013 & $\begin{array}{l}2013 / \\
2003 \\
\end{array}$ \\
\hline \multicolumn{13}{|l|}{ Processor prices } \\
\hline $\begin{array}{l}\text { Marketing semi } \\
\text { fat milk, durable } \\
(\mathrm{EUR} / \mathrm{l})\end{array}$ & 0.47 & 0.49 & 0.49 & 0.48 & 0.47 & 0.52 & 0.34 & 0.40 & 0.43 & 0.40 & 0.45 & 95.7 \\
\hline $\begin{array}{l}\text { Nature yoghurt - } \\
\text { fat max. } 4.6 \text { per } \\
\text { cent }(E U R / k g)\end{array}$ & 1.20 & 1.36 & 1.48 & 1.42 & 1.41 & 1.60 & 1.36 & 1.36 & 1.35 & 1.39 & 1.42 & 118.3 \\
\hline $\begin{array}{l}\text { Edam cheese } \\
(\text { EUR/kg) }\end{array}$ & 3.54 & 3.60 & 3.83 & 3.55 & 3.46 & 4,18 & 3.16 & 3.91 & 4.16 & 4.19 & 4.69 & 132.5 \\
\hline Butter (EUR/kg) & 3.42 & 3.75 & 3.81 & 3.84 & 3.80 & 4.19 & 3.41 & 4.13 & 4.66 & 4.32 & 4.49 & 131.3 \\
\hline \multicolumn{13}{|l|}{ Consumer prices } \\
\hline $\begin{array}{l}\text { Marketing semi fat } \\
\text { liquid milk (EUR/l) }\end{array}$ & 0.60 & 0.65 & 0.66 & 0.64 & 0.66 & 0.73 & 0.60 & 0.62 & 0.71 & 0.74 & 0.76 & 126.7 \\
\hline $\begin{array}{l}\text { Edam cheese } \\
(\mathrm{EUR} / \mathrm{kg})\end{array}$ & 5.27 & 5.73 & 5.61 & 5.46 & 5.84 & 6.30 & 4.94 & 5.36 & 6.11 & 6.21 & 6.28 & 119.2 \\
\hline
\end{tabular}

Source: SO SR

In the Czech Republic, prices throughout the dairy chain have generally shown an upward trend with some exceptions in terms of particular years (2009 especially) and some product deviations (Table 20). The dairy product structure showed a rather significant increase in low value added products (drinking milk, fermented milk products) and a decrease in high value added products (cheese). That is the consequence of a massive growth in cheese imports. 
Table 20: Prices throughout the dairy chain in the Czech Republic, 2003-2013.

\begin{tabular}{|c|c|c|c|c|c|c|c|c|c|c|c|c|}
\hline Farm price & 2003 & 2004 & 2005 & 2006 & 2007 & 2008 & 2009 & 2010 & 2011 & 2012 & 2013 & $\begin{array}{l}2013 / \\
2003\end{array}$ \\
\hline $\begin{array}{l}\text { Raw milk average price } \\
(\mathrm{EUR} / 100 \mathrm{~kg})\end{array}$ & 23.47 & 25.61 & 27.83 & 27.38 & 30.95 & 31.52 & 22.91 & 28.74 & 31.53 & 29.64 & 30.13 & 128.4 \\
\hline \multicolumn{13}{|c|}{ Processor prices } \\
\hline $\begin{array}{l}\text { Marketing semi fat milk, } \\
\text { durable (EUR/l) }\end{array}$ & 0.38 & 0.42 & 0.39 & 0.38 & 0.43 & 0.48 & 0.36 & 0.39 & 0.41 & 0.39 & 0.41 & 107.9 \\
\hline Edam cheese (EUR/kg) & 2.62 & 2.93 & 3.30 & 3.32 & 3.88 & 4.12 & 3.19 & 3.43 & 3.68 & 3.69 & 3.65 & 139.3 \\
\hline Butter (EUR/kg) & 2.69 & 3.13 & 3.14 & 3.01 & 3.50 & 3.26 & 2.87 & 3.67 & 3.97 & 3.59 & 3.80 & 141.3 \\
\hline \multicolumn{13}{|c|}{ Consumer prices } \\
\hline $\begin{array}{l}\text { Marketing semi fat liquid } \\
\text { milk (EUR/l) }\end{array}$ & 0.44 & - & 0.49 & 0.48 & 0.58 & 0.66 & 0.53 & 0.59 & 0.64 & 0.66 & 0.66 & 150.0 \\
\hline Edam cheese (EUR/kg) & 3.45 & - & 3.89 & 3.97 & 4.64 & 5.11 & 4.25 & 4.74 & 4.78 & 5.08 & 5.14 & 149.0 \\
\hline
\end{tabular}

Source: MZe and CZSO

In Hungary, the abolition of the national price support system at the beginning of 2004 led to a fall in raw milk prices. Since Hungary's accession to the EU, milk prices have been more affected by the changes in the international prices through the prices of the EU. Hungarian raw milk prices are moving very close to the prices of other EU Member States (Szajner and Vöneki, 2013). The purchase price of milk in Hungary is mainly determined by the prices that can be obtained for Hungarian exports (Figure 3 ).

Figure 3: Farm price and export price of raw cow milk in Hungary, 2003-2013.

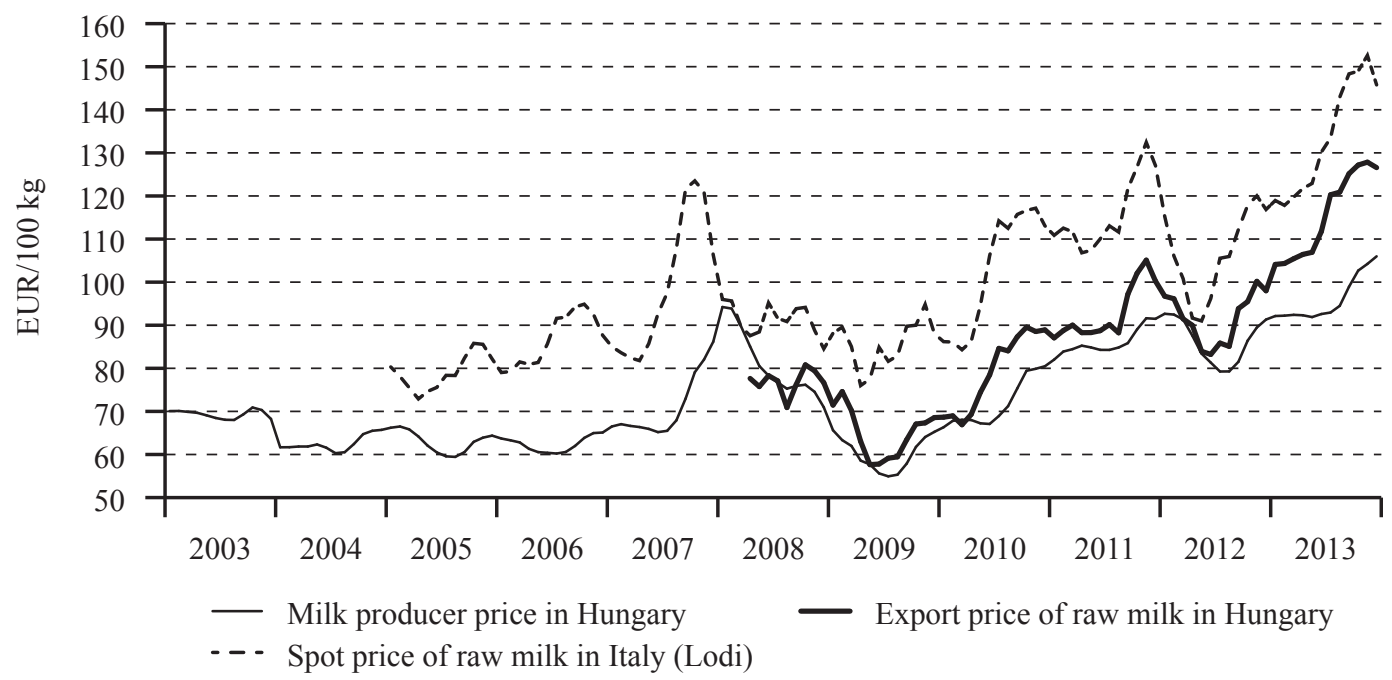

Source: AKI PÁIR, Italian Chambers of Commerce Industry Handicraft and Agriculture of Lodi

Based on the price data of the first four months of 2014, Hungarian raw milk prices were among the lowest in the EU. During this time, raw milk prices in euro terms were lower only in Poland, the Czech Republic, Latvia and Romania. The average Hungarian raw milk price amounted to 89 per cent of the average of the EU-28 (Figure 4). The standardised data show that the price advantage of Hungarian raw milk is a consequence of the slightly lower fat and protein contents. 
Figure 4: Raw milk producer price in the EU Member States, 2014.04.

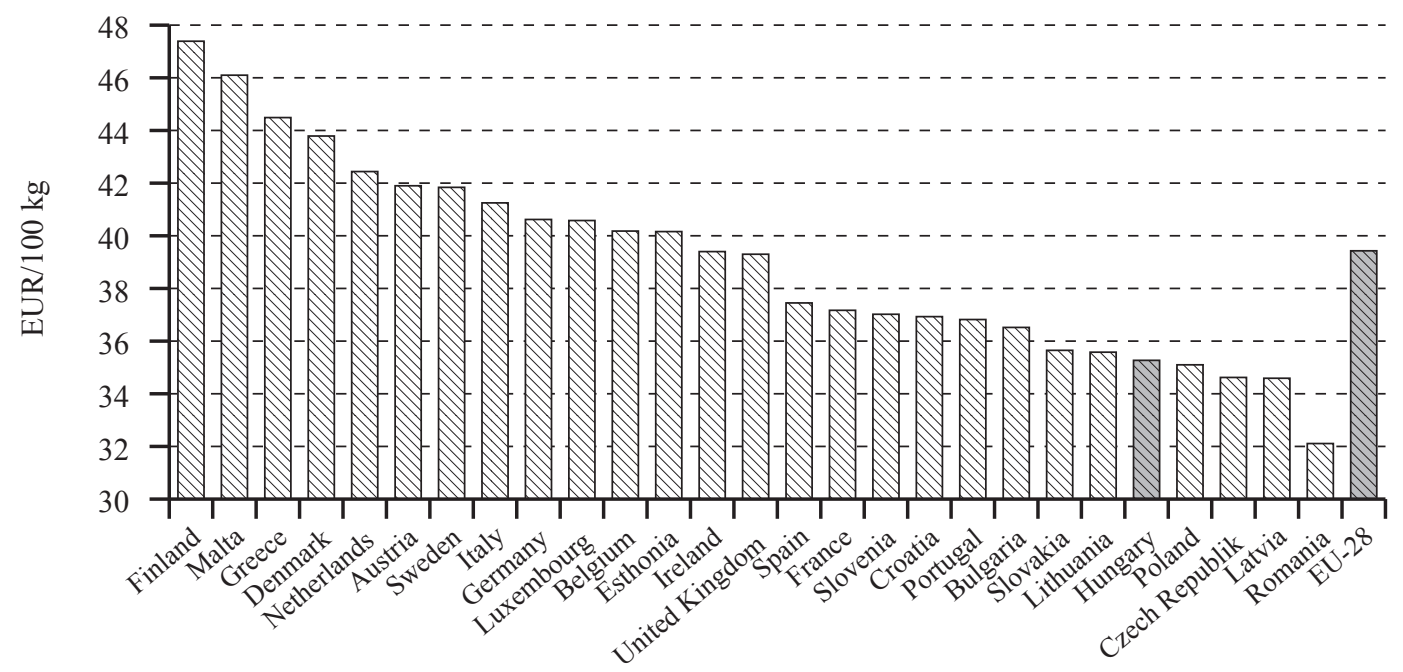

Source: EC European Milk Market Observatory

As a consequence of the direct commercial relationship, changes in the dairy product prices in other EU Member States strongly affect the Hungarian market for dairy products. By importing from other countries, the retail chains compel the Hungarian dairy industry to adapt. Between 2003 and 2013, retail prices of cheese and pasteurised milk were more volatile than wholesale prices (Table 21). In national currency the retail prices increased much more in this period than did wholesale prices or the producer price of raw milk which illustrates the relatively strong bargaining power of the retail chains in the Hungarian food sector.

Table 21: Processor prices (excluding VAT) and consumer prices of selected milk products (including VAT) in Hungary, 2003-2013.

\begin{tabular}{lccccccccccccc}
\hline Processor prices & $\mathbf{2 0 0 3}$ & $\mathbf{2 0 0 4}$ & $\mathbf{2 0 0 5}$ & $\mathbf{2 0 0 6}$ & $\mathbf{2 0 0 7}$ & $\mathbf{2 0 0 8}$ & $\mathbf{2 0 0 9}$ & $\mathbf{2 0 1 0}$ & $\mathbf{2 0 1 1}$ & $\mathbf{2 0 1 2}$ & $\mathbf{2 0 1 3}$ & $\begin{array}{r}\mathbf{2 0 1 3} \\
\mathbf{2 0 0 3}\end{array}$ \\
\hline Butter & 3.56 & 3.80 & 3.69 & 3.59 & 4.01 & 4.31 & 3.63 & 4.01 & 4.67 & 4.64 & 4.77 & 134.0 \\
\hline Butter cream & 2.71 & 2.77 & 2.72 & 2.55 & 2.80 & 2.94 & 2.53 & 2.65 & 2.88 & 2.69 & 2,78 & 102.6 \\
\hline Cottage cheese & 2.22 & 2.20 & 2.14 & 2.07 & 2.34 & 2.59 & 2.13 & 2.12 & 2.21 & 2.10 & 2.13 & 95.9 \\
\hline Sour cream & 1.15 & 1.14 & 1.14 & 1.11 & 1.26 & 1.34 & 1.11 & 1.17 & 1.31 & 1.28 & 1.31 & 113.9 \\
\hline Nature yoghurt & 1.07 & 1.10 & 1.18 & 1.10 & 1.40 & 1.52 & 1.30 & 1.27 & 1.22 & 1.05 & 1.02 & 95.3 \\
\hline Fruit yoghurt & 1.28 & 1.27 & 1.21 & 1.19 & 1.42 & 1.43 & 1.24 & 1.34 & 1.39 & 1.35 & 1.32 & 103.1 \\
\hline Trappista cheese & 3.69 & 3.49 & 3.35 & 3.33 & 3.92 & 4.10 & 2.92 & 3.38 & 3.90 & 3.55 & 3.95 & 107.0 \\
\hline Cream cheese & 3.80 & 3.75 & 3.85 & 3.68 & 3.93 & 4.42 & 3.97 & 3.83 & 4.01 & 3.69 & 3.54 & 93.2 \\
\hline & & & & $\mathbf{C o n s u m e r}$ & price & & & & & & \\
\hline $\begin{array}{l}\text { Pasteurized milk, } \\
\text { 2.8 per cent fat }\end{array}$ & 0.61 & 0.61 & 0.61 & 0.62 & 0.72 & 0.85 & 0.70 & 0.71 & 0.79 & 0.78 & 0.77 & 126.2 \\
\hline Trappista cheese & 5.25 & 5.80 & 4.80 & 4.65 & 5.49 & 6.21 & 4.53 & 5.08 & 5.52 & 5.42 & 5.69 & 108.4 \\
\hline
\end{tabular}

Source: HCSO, AKI PÁIR 


\section{Consumption}

Consumption of milk and milk products per inhabitant is low in Slovakia (Table 22). In 2013, it reached a level of $158.5 \mathrm{~kg}$. The situation is affected by consumption habits and the retail price level in relation to average incomes of inhabitants. In 2003-2013, the upward trend was monitored by consumption of cheeses, butter and fermented milk products. By contrast, the consumption of marketing milk fell.

In Hungary, domestic demand for milk and milk products has not increased during recent years, remaining far below the level of the 1990s. For example, the consumption of cheese, a typical high value added product, is much lower in Hungary than in the more developed European countries. Per capita consumption of milk and dairy products amounted to $156.2 \mathrm{~kg}$ in milk equivalent in 2012 , according to the data of the Hungarian Central Statistical Office (HCSO), which corresponds to the level of 2000 (Table 23).

Table 22: Average consumption of milk and milk products per inhabitant in Slovakia, 2003-2013.

\begin{tabular}{lrrrrrrrrrrrrrr}
\hline \multicolumn{1}{c}{ Indicator } & $\mathbf{2 0 0 3}$ & $\mathbf{2 0 0 4}$ & $\mathbf{2 0 0 5}$ & $\mathbf{2 0 0 6}$ & $\mathbf{2 0 0 7}$ & $\mathbf{2 0 0 8}$ & $\mathbf{2 0 0 9}$ & $\mathbf{2 0 1 0}$ & $\mathbf{2 0 1 1}$ & $\mathbf{2 0 1 2}$ & $\mathbf{2 0 1 3}$ & $\begin{array}{c}\mathbf{2 0 1 3} / \\
\mathbf{2 0 0 3}\end{array}$ \\
\hline $\begin{array}{l}\text { Milk and milk } \\
\text { products in total }\end{array}$ & 158,3 & 153,3 & 154,6 & 152,4 & 153,4 & 153,0 & 153,8 & 162,8 & 156,9 & 158,6 & 158,5 & 100,1 \\
\hline - Liquid milk & 63,9 & 59,1 & 55,7 & 55,9 & 52,4 & 48,3 & 49,5 & 54,5 & 53,1 & 54,3 & 49,3 & 77,2 \\
\hline - Cheese and curd & 9,3 & 8,2 & 9,1 & 9,5 & 9,8 & 9,2 & 9,8 & 9,9 & 10,4 & 10,1 & 11,4 & 122,6 \\
\hline - Butter & 2,8 & 2,2 & 2,0 & 2,0 & 2,1 & 2,2 & 2,8 & 2,6 & 2,9 & 3,2 & 3,0 & 107,1 \\
\hline $\begin{array}{l}\text { - Fermented } \\
\text { products }\end{array}$ & 12,4 & 12,6 & 13,1 & 12,3 & 13,7 & 13,8 & 13,7 & 13,8 & 13,7 & 14,3 & 14,7 & 118,5 \\
\hline
\end{tabular}

Source: SO SR

The difference between the EU and Hungary is relatively small for fluid milk, cream, sour cream and cheese, while smaller quantities of fermented products, flavoured milk drinks, cheese, cottage cheese, butter and condensed milk are consumed in Hungary than in other Member States. Hungarian cheese consumption is near to the level of the consumption of the former socialist countries. However, for butter and, to a lesser extent, fluid milk the gap is larger. Per capita consumption of fluid milk reached $50.5 \mathrm{~kg}$ in 2012, which is 23 per cent less than the EU average. Per capita consumption of cheese and cottage cheese was only one third of the EU average; it has not changed in recent years and amounted to $5.6 \mathrm{~kg}$ in 2012. Per capita consumption of butter and fermented milk products havd stagnated in recent years and amounted to only about $0.8 \mathrm{~kg}$ and $11.8 \mathrm{~kg}$ respectively. The low level of butter consumption can be explained by the negative image of the product in recent years. 
Table 23: Per capita consumption of dairy products in Hungary, 2003-2012.

\begin{tabular}{lrrrrrrrrrrrrr}
\hline \multicolumn{1}{c}{ Indicator } & $\mathbf{2 0 0 3}$ & $\mathbf{2 0 0 4}$ & $\mathbf{2 0 0 5}$ & $\mathbf{2 0 0 6}$ & $\mathbf{2 0 0 7}$ & $\mathbf{2 0 0 8}$ & $\mathbf{2 0 0 9}$ & $\mathbf{2 0 1 0}$ & $\mathbf{2 0 1 1}$ & $\mathbf{2 0 1 2}$ & $\begin{array}{c}\text { kg12/ } \\
\mathbf{2 0 0 3}\end{array}$ \\
\hline Milk and milk products & 161.2 & 175.5 & 186.0 & 182.7 & 183.2 & 178.1 & 174.3 & 179.9 & 174.9 & 180.4 & 111.9 \\
\hline - Liquid milk & 64.9 & 63.6 & 62.3 & 60.4 & 58.6 & 55.4 & 55.1 & 54.5 & 51.9 & 52.0 & 80.1 \\
\hline - Cheese and curd & 5.2 & 5.6 & 5.7 & 5.8 & 5.7 & 5.7 & 5.5 & 5.4 & 5.6 & 5.7 & 109.6 \\
\hline - Butter & 0.7 & 0.7 & 0.8 & 0.8 & 0.8 & 0.9 & 0.9 & 0.9 & 0.8 & 0.8 & 114.3 \\
\hline - Fermented products & 11.3 & 12.0 & 12.0 & 12.4 & 13.0 & 13.1 & 12.7 & 12.4 & 11.9 & 12.2 & 108.0 \\
\hline
\end{tabular}

Source: HCSO

In Hungary, 260-270 kg milk equivalent per capita consumption would be appropriate as a basic public health requirement which is nearly double of the current volume. A significantly increase is unlikely in the medium term, because it requires a much greater and more dynamic growth of purchasing power. Hungarian consumption has not increased in recent years despite of the fact that according to the survey of GfK (2013) cheese, drinking milk and sour cream were classified among the 15 most popular foods in Hungary. Regarding the frequency of consumption, milk products were in third place after bread and coffee: 64 per cent of the respondents consumed these products on a daily basis. In the background of the low consumption - in addition to the traditional culinary culture - are the low proportion of health-conscious consumers, misconceptions relating to milk products, low awareness and support of indications and trademarks, and most of all the price sensitivity of domestic consumers (Hungarian Dairy Producer and Inter-branch Organisation, 2013).

\section{Trade}

The foreign trade of Slovakia is oriented towards EU Member States. In the long term, Slovakia was a net exporter of milk products (except of fermented milk products and butter). This situation markedly changed in 2009 when Slovakia's trade balances in milk powder and cheese started to become negative (Figure 5). Nonetheless, Slovak cheeses remain one of the crucial export commodities for their high quality. In 2013 cheeses were exported predominantly to the Czech Republic (28.9 per cent), the United Kingdom (17.8 per cent), Hungary (19.4 per cent), Germany (12.3 per cent), Belgium (8.5 per cent) and Italy (5.8 per cent). Another important export commodity is liquid milk. In 2013, liquid milk was exported mainly to Hungary (42.8 per cent), Italy (27.9 per cent), the Czech Republic (13.9 per cent), Germany (3.5 per cent) and Poland (2.3 per cent).

Pursuant to the WTO ban on export subsidies, milk powder production and consequently its export was reduced in all EU Member States including Slovakia (Table 24). Milk powder was exported from Slovakia also to third countries (Near East) due to export subsidies. At present, Slovakia is not self-sufficient in milk powder and partially depends on imports. In 2013, milk powder was exported especially to the Czech Republic (45.3 per cent), Serbia (12.2 per cent), Hungary (5.3 per cent) and Germany (10.2 per cent). Butter was exported primarily to the Czech Republic (57.2 per cent), Hungary (24.1 per cent) and Romania (11.1 per cent); fermented milk products were exported to Spain (74.9 per cent), the Czech Republic (12.0 per cent) and France (9.0 per cent) and whey was exported mainly to the Czech Republic (36.0 per cent), Bulgaria (16.9 per cent), Italy (21.5 per cent) and Poland (13.3 per cent). 
Figure 5: Trade balance with milk and milk products in Slovakia, 2003-2013.

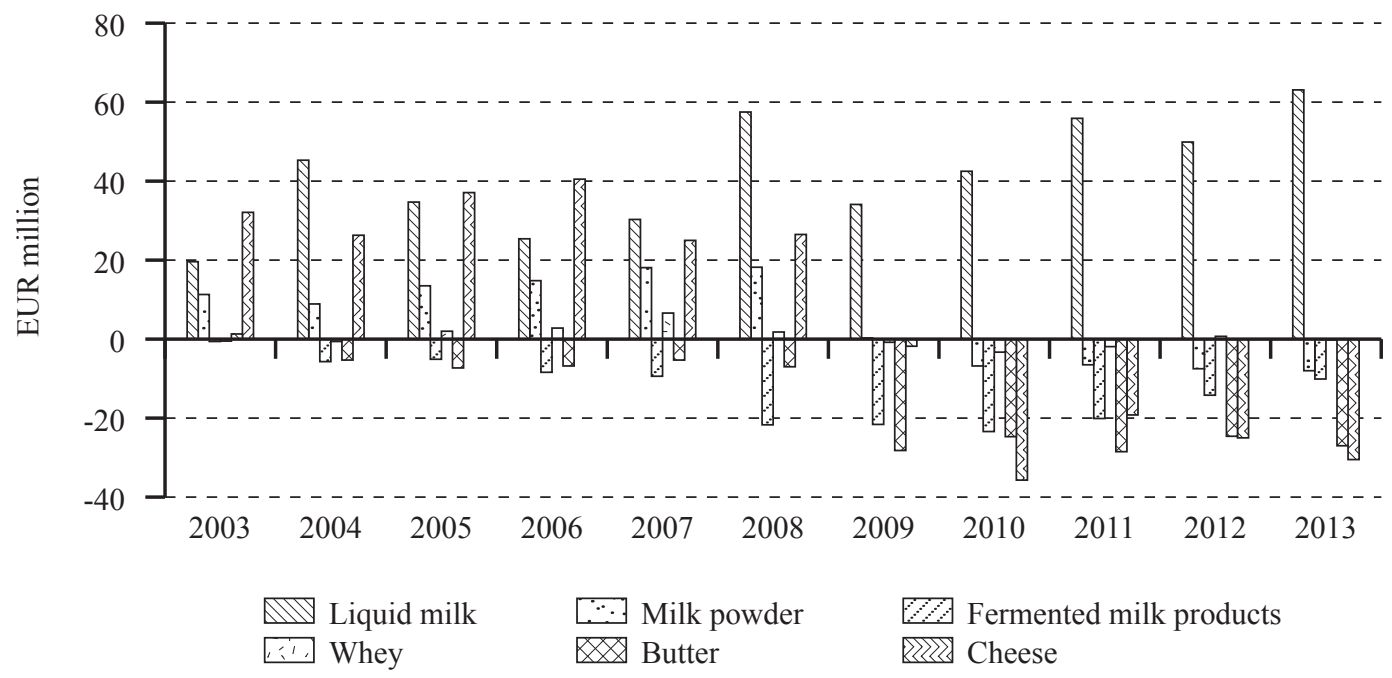

Source: SO SR, NPPC-VÚEPP

Table 24: The SR foreign trade with milk and milk products of Slovakia, 2003-2013.

\begin{tabular}{|c|c|c|c|c|c|c|c|c|c|c|c|c|}
\hline HS code/description/year & 2003 & 2004 & 2005 & 2006 & 2007 & 2008 & 2009 & 2010 & 2011 & 2012 & 2013 & $\begin{array}{l}2013 / \\
2003\end{array}$ \\
\hline \multicolumn{13}{|c|}{ Export } \\
\hline 0401 Liquid milk & 22.1 & 54.2 & 71.0 & 63.2 & 73.3 & 105.9 & 65.0 & 91.7 & 112.6 & 92.5 & 123.5 & 558.8 \\
\hline 0402 Milk powder & 21.6 & 17.6 & 44.6 & 32.2 & 57.7 & 40.0 & 16.1 & 10.1 & 10.7 & 11.9 & 18.0 & 83.3 \\
\hline 0403 Fermented products & 10.3 & 7.5 & 15.8 & 19.9 & 21.0 & 17.9 & 16.1 & 15.0 & 19.2 & 22.9 & 26.0 & 252.4 \\
\hline 0404 Whey & 1.1 & 2.2 & 4.8 & 6.8 & 12.0 & 4.9 & 3.5 & 4.7 & 6.6 & 7.3 & 7.7 & 700.0 \\
\hline 0405 Butter & 6.2 & 5.7 & 6.0 & 6.0 & 12.5 & 8.9 & 5.2 & 5.2 & 7.2 & 10.6 & 14.9 & 240.3 \\
\hline 0406 Cheese & 50.6 & 54.9 & 81.4 & 95.1 & 82.2 & 95.8 & 68.8 & 99.3 & 85.0 & 87.4 & 99.6 & 196.8 \\
\hline \multicolumn{13}{|c|}{ Import } \\
\hline 0401 Liquid milk & 2.5 & 8.9 & 36.3 & 37.8 & 43.0 & 48.4 & 30.9 & 49.2 & 56.7 & 42.5 & 60.3 & 2412.0 \\
\hline 0402 Milk powder & 10.3 & 8.7 & 36.1 & 17.5 & 39.6 & 21.7 & 15.8 & 16.9 & 17.2 & 24.8 & 27.2 & 264.1 \\
\hline 0403 Fermented products & 10.8 & 13.2 & 20.9 & 28.3 & 30.5 & 39.7 & 37.7 & 38.5 & 39.3 & 35.8 & 35.6 & 329.6 \\
\hline 0404 Whey & 1.6 & 2.8 & 2.8 & 4.0 & 5.4 & 3.0 & 4.3 & 7.9 & 8.5 & 7.1 & 7.0 & 437.5 \\
\hline 0405 Butter & 5.0 & 11.0 & 13.4 & 12.8 & 17.8 & 15.9 & 33.4 & 29.9 & 35.7 & 42.1 & 41.5 & 830.0 \\
\hline 0406 Cheese & 18.5 & 28.5 & 44.2 & 54.5 & 57.2 & 69.3 & 70.6 & 135.1 & 104.2 & 130.6 & 138.7 & 749.7 \\
\hline
\end{tabular}

Source: SO SR, NPPC-VÚEPP

The development of milk products kilogramme prices in 2003-2013 differed according to the value added of milk products. Prices of liquid milk, whey and fermented milk products swung less than prices of butter, cheeses and milk powder (Figure 6 and 7). 
Figure 6: Export prices (EP) of selected milk products in Slovakia, 2003-2013.

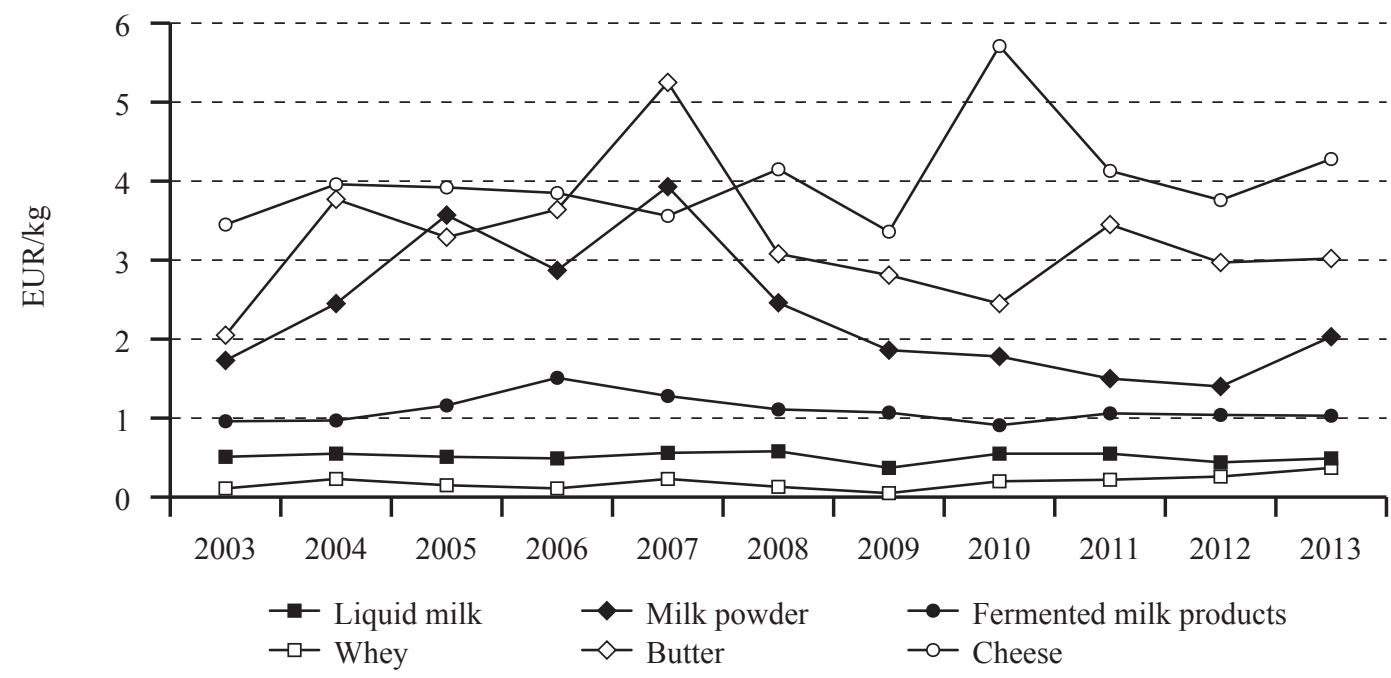

Source: SO SR, NPPC-VÚEPP

Figure 7: Import (IP) prices of selected milk products in Slovakia, 2003-2013.

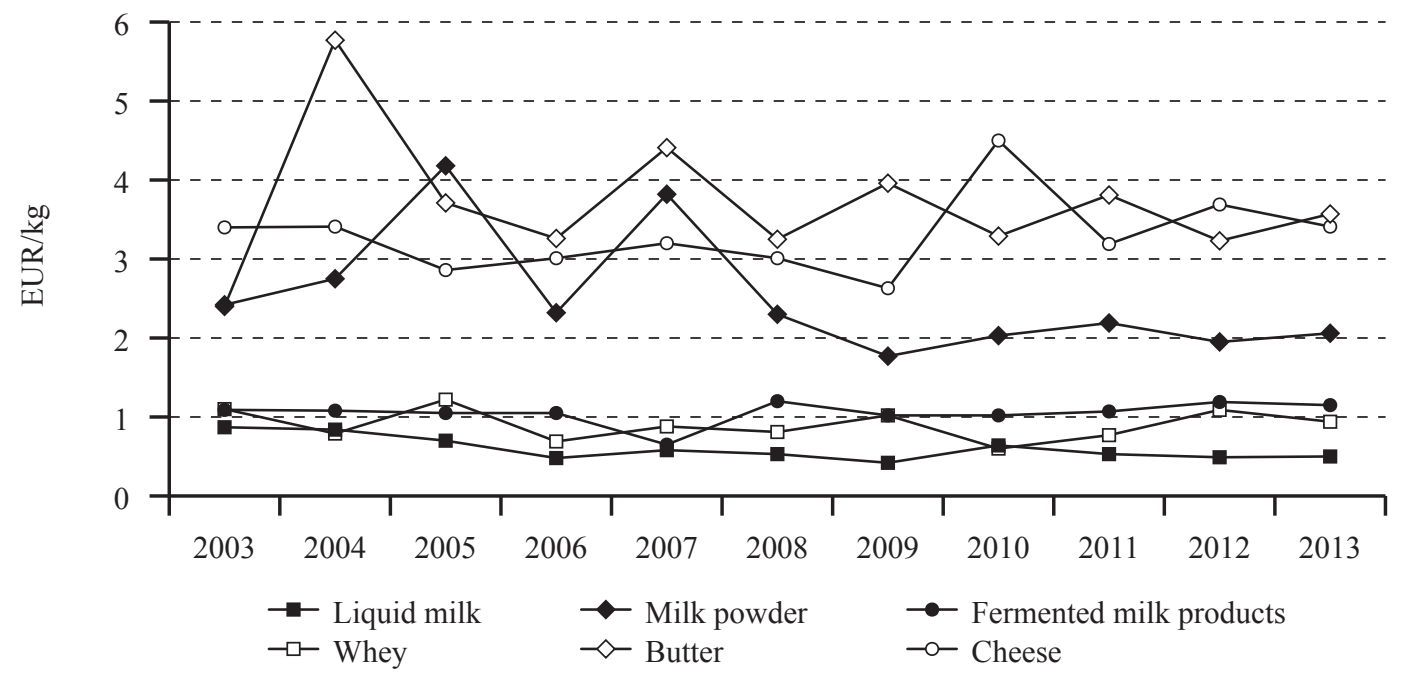

Source: SO SR, NPPC-VÚEPP

Export prices of cheeses were higher than import prices throughout the period 2003-2013. The opposite situation existed for other milk products, i.e. their export prices were lower than import prices in most monitored period (Figure 8). 
Figure 8: Difference between import (IP) and export (EP) prices in Slovakia, 2003-2013.

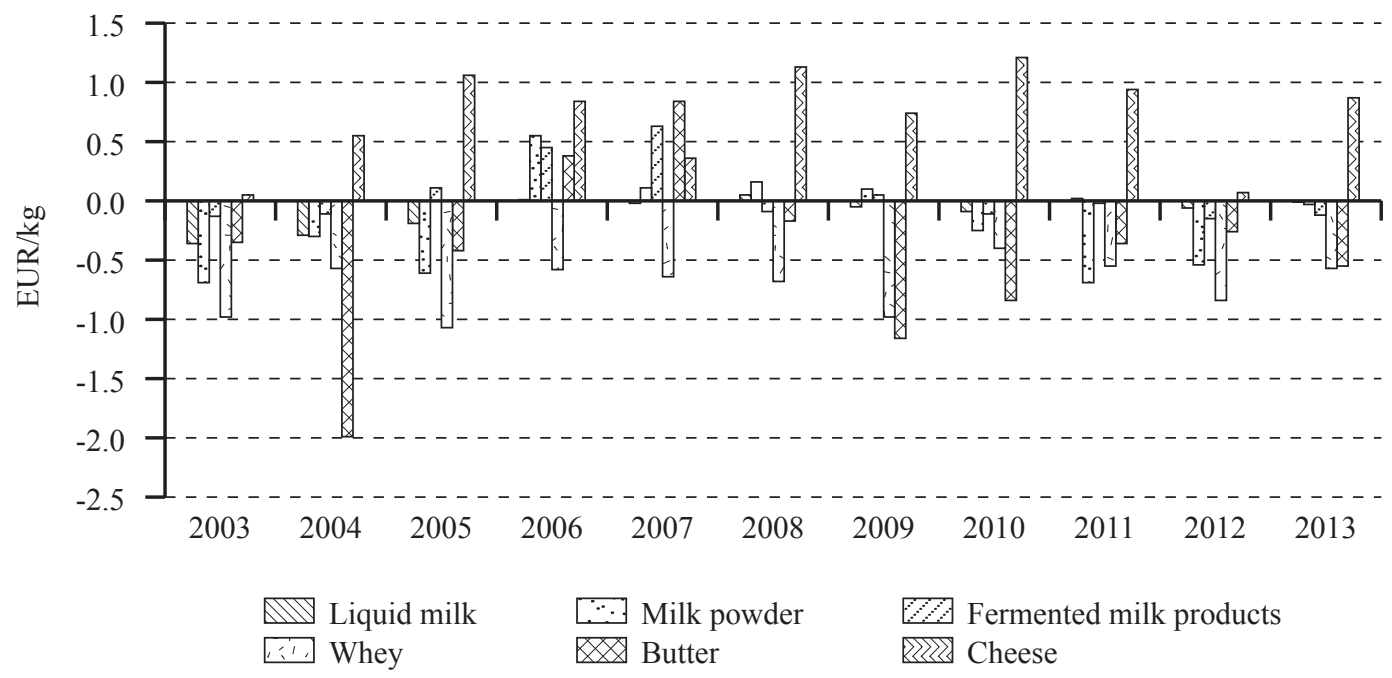

Source: SO SR, NPPC-VÚEPP

In the Czech Republic (Table 25), one of the most distinct trends visible in the milk balance is the more than 300 per cent increase in milk products imports, while exports increased by about 34 per cent only, predominantly due to an increase in raw milk exports. The self-sufficiency is more than 120 per cent. However, the self-sufficiency of milk products supply is significantly lower. At least by about 18 per cent, as this share of raw milk is being exported unprocessed. Milk consumption in the country is more or less stable with slight deviations, frequently related to milk price levels.

Table 25: Balance of purchased cow milk in the Czech Republic, 2003-2013.

million litres

\begin{tabular}{|c|c|c|c|c|c|c|c|c|c|c|c|c|}
\hline Indicator & 2003 & 2004 & 2005 & 2006 & 2007 & 2008 & 2009 & 2010 & 2011 & 2012 & 2013 & $\begin{array}{l}2013 / \\
2003\end{array}$ \\
\hline Beginning stocks & 133 & 92 & 69 & 66 & 56 & 71 & 98 & 60 & 61 & 125 & 62 & 46.6 \\
\hline Milk purchase from farmers & 2,531 & 2,496 & 2,476 & 2,330 & 2,381 & 2,369 & 2,292 & 2,251 & 2,304 & 2,382 & 2,320 & 91.7 \\
\hline Import $^{\text {a) }}$ & 281 & 330 & 535 & 701 & 836 & 810 & 854 & 849 & 853 & 899 & 880 & 313.2 \\
\hline Supply & 2,945 & 2,918 & 3,081 & 3,097 & 3,273 & 3,250 & 3,243 & 3,160 & 3,218 & 3,349 & 3,261 & 110.7 \\
\hline Exporta) $^{\text {a) }}$ & 772 & 738 & 833 & 851 & 958 & 938 & 910 & 902 & 1010 & 1086 & 1042 & 135.0 \\
\hline Domestic consumption & 2,081 & 2,110 & 2,182 & 2,191 & 2,244 & 2,215 & 2,233 & 2,197 & 2,139 & 2,201 & 2,156 & 103.6 \\
\hline Demand & 2,853 & 2,848 & 3,015 & 3,042 & 3,202 & 3,152 & 3,183 & 3,099 & 3,149 & 3,287 & 3,198 & 112.1 \\
\hline Ending stocks & 92 & 69 & 66 & 56 & 71 & 98 & 60 & 61 & 69 & 62 & 63 & 68.5 \\
\hline Self-sufficiency ( per cent) & 127 & 123 & 126 & 123 & 120 & 123 & 121 & 119 & 125 & 125 & 129 & 101.6 \\
\hline
\end{tabular}

a) Import and export of milk and milk products are calculated per liquid milk.

Source: MZe, IAEI

Since 2004, Hungary has been a net importer of milk and dairy products both in volume and in value. Both imports and exports have increased significantly, most of all due to the intensification of the trade relations with the other Member States. A significant improvement of the trade balance can be observed from 2011 (Figure 9). 
Figure 9: Dairy trade balance of Hungary, 2004-2013.

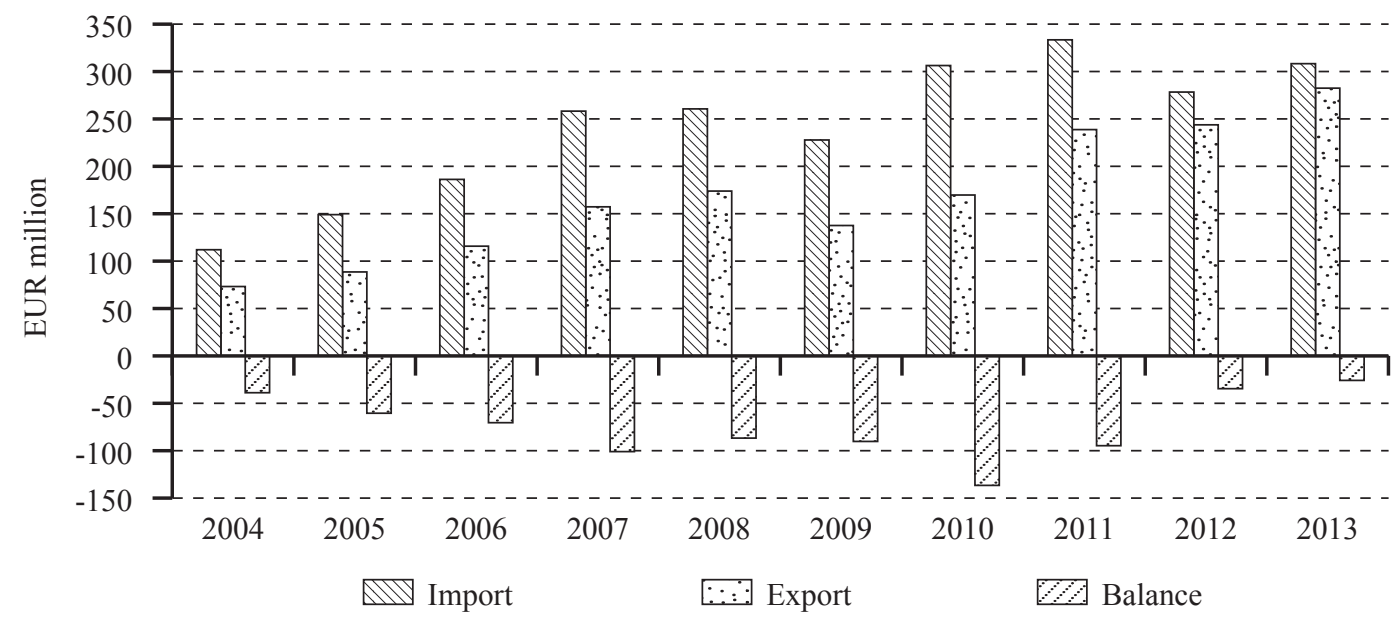

Source: HCSO

The different levels of competitiveness of production and processing can be seen in the trade structure. Imports consisted mainly of high value added products such as cheese and fermented milk products while Hungary exports mainly raw and skimmed milk (Figure 10 and 11).

Figure 10: Import value of milk and dairy products of Hungary, 2003-2013.

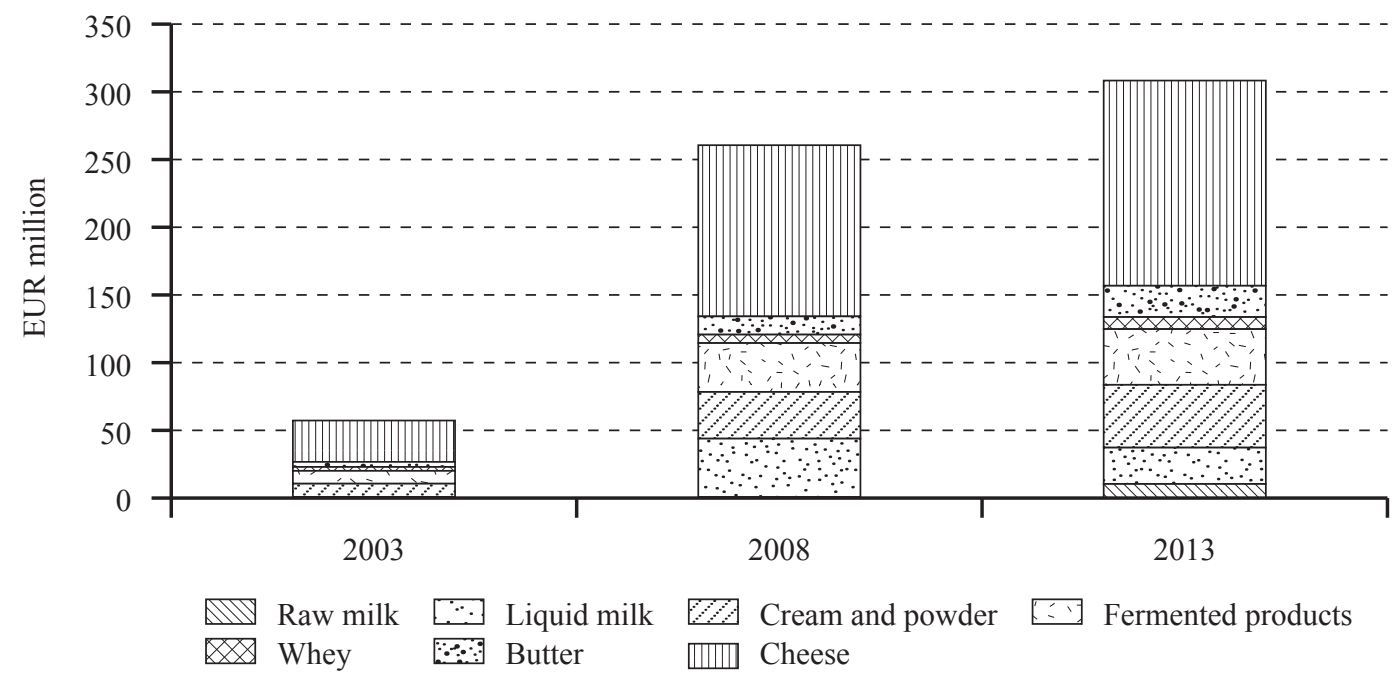

Source: HCSO 
Figure 11: Export value of milk and dairy products of Hungary, 2003-2013.

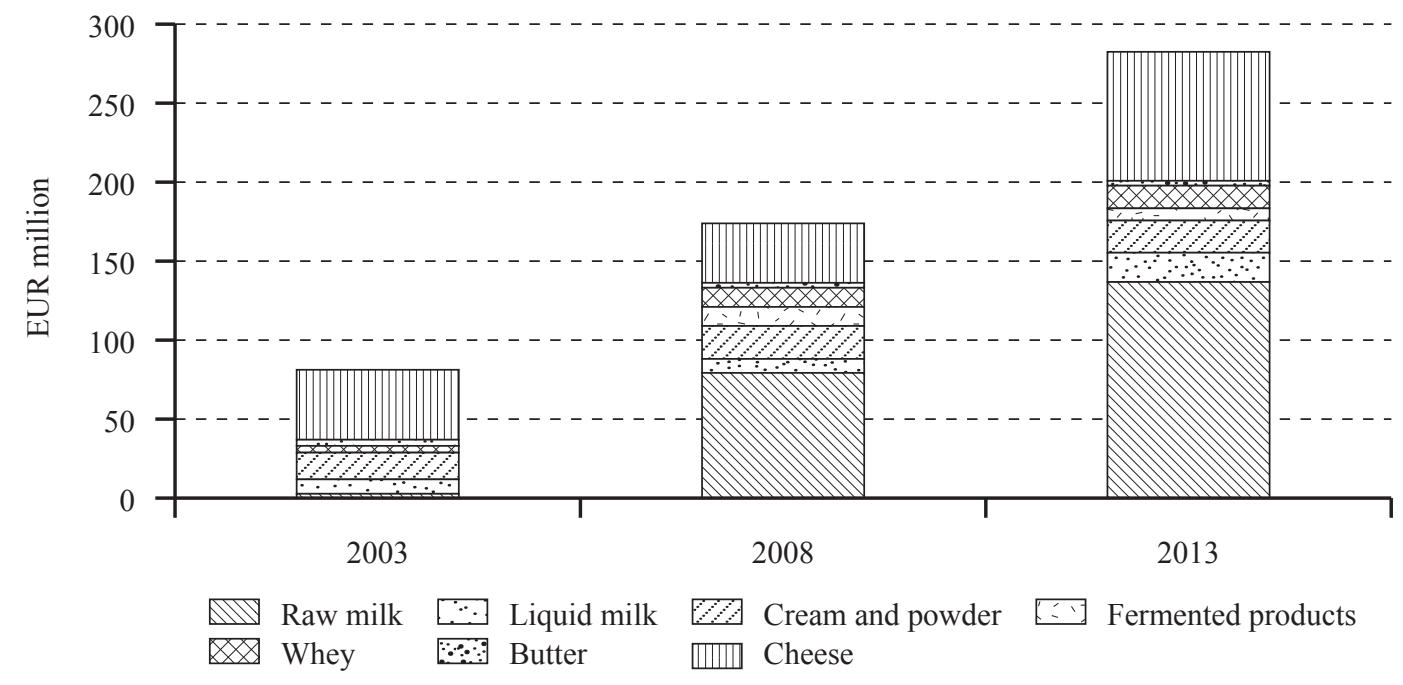

Source: HCSO

The key suppliers of Hungary are Germany and Poland with a combined 58 per cent share of the total Hungarian dairy imports. These two market players have exported increasing amounts of dairy products to Hungary (Figure 12). Slovakia, Austria and the Czech Republic had a combined 22 per cent share of total Hungarian dairy imports in 2013. Germany and Poland exported mainly cheese and fermented milk products to Hungary while Slovakia, Austria and the Czech Republic exported mainly fluid milk.

Figure 12: Import of milk and dairy products of Hungary in milk equivalent, 2003-2013.

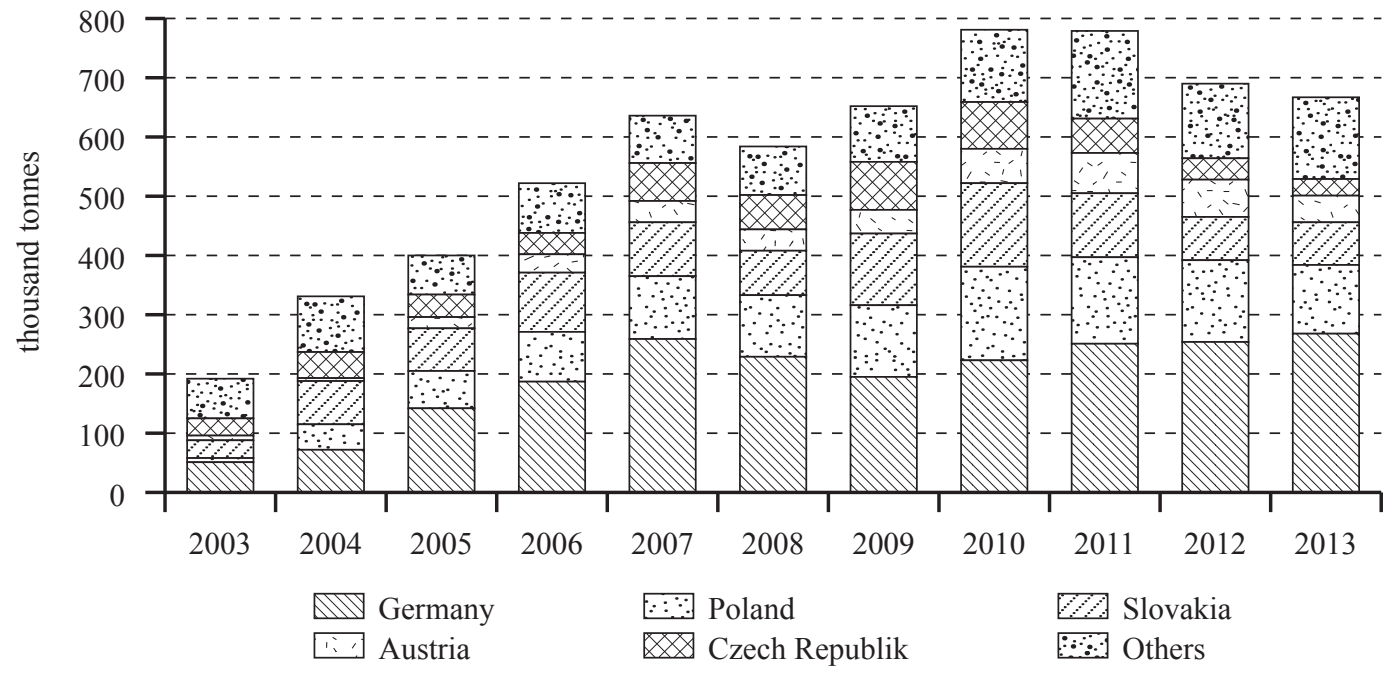

Source: HCSO

The most important markets are Italy, Romania and Slovakia, but Croatia is also importing increasing amounts of Hungarian raw milk (Figure 13). 
Figure 13: Export of milk and dairy products of Hungary in milk equivalent, 2003-2013.

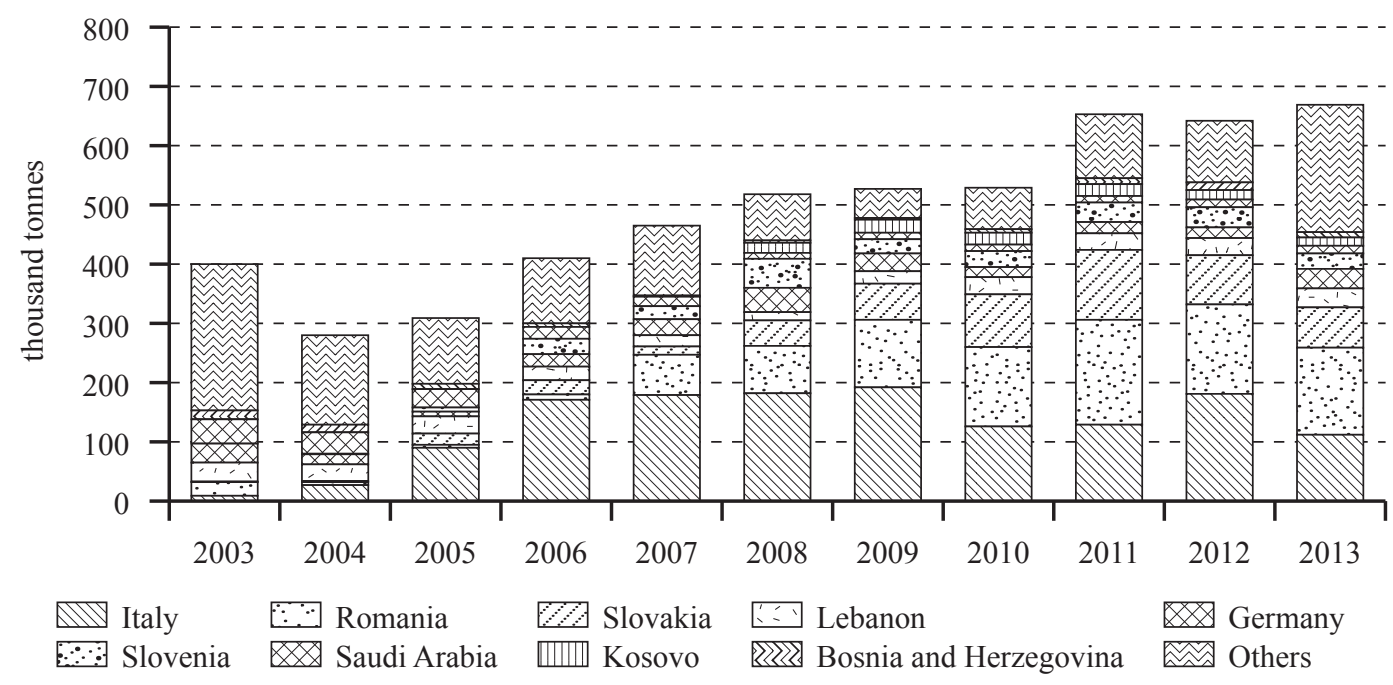

Source: HCSO

\section{Milk quota system and direct support of milk production}

The milk quota system that regulated cow milk production in EU Member States was introduced in 1984. The underlying reason for this measure was the financial problems caused by the increasing butter and milk powder reserves. The previous system provided a price guarantee and intervention for producers regardless of the quantity produced. Until the introduction of the direct milk supports in 2004, the milk quota system was the only measure that had a direct impact on EU milk production. The quotas that were defined both for the Member States and the producers also affected the processors, as the rules related to their raw material base and limited the processing quantity. The system has been, since its creation, constantly adjusted due the changes occurring in the market. In line with a decision of the EC in 2003, the quota system was abolished after 31 March 2015, and in order to ensure a 'soft landing' for the sector, the quotas have been raised by one percent annually from 1 April 2009, with the last increase occurring on 1 April 2013 (EC, 2012a).

Despite the growth in production of recent years, according to annual data sets submitted to the EU by individual Member States as specified by Commission Regulation 595/2004, the quantity of milk bought and directly sold has remained below the quota. The so-called 'lagging behind' started to become noticeable from 2009. The quantity of the milk supplied grew by 2.9 per cent to 144 million tonnes (corrected by fat content) in the 2013/14 quota year but the quota itself increased by 1.4 per cent to 150 million tonnes, thus quota utilisation increased from 94.0 to 95.4 per cent in comparison with the previous quota year. The increases in the quantity of milk bought and in the quotas were partly explained by Croatia's accession to the EU. The quota use in the EU-15 stood at 96.8 per cent. In most EU regions it was not the quantitative restrictions that hampered the increase in milk production during the phasing-out of the milk quota, but other factors such as the area of available agricultural land, the costs of financing, the environmental restrictions and the retail price war (EC, 2012b). In the quota year 2013/2014, the utilisation of the milk quota was the lowest in Bulgaria, Romania and Hungary (Figure 14).

Since the EU accession (in quota years 2004/2005-2012/2013), the national quota has never been fully used in Slovakia. In the quota year 2013/2014, 77,2 per cent of the national quota was used. In 2003-2013, without direct support, milk producers in Slovakia made a loss of EUR 0.01 to 0.14 
per litre of milk. This loss was eliminated by direct support. Only 2009 was crucial with regard to ultralow milk prices. However, in the same period the number of suckler cows increased.

In the Czech Republic, dairy production has remained below the quota limit since 2006-2007. Its utilisation had a decreasing trend until 2010/11 and only slightly recovered in last two years. The so called 'soft landing' scheme (which is basically the annual quota increase accompanied by other market measurements) was introduced in 2009 to prepare the branch for the quota abolition on 31 March 2015. Thus the farmers gained the opportunity to benefit from the increasing milk demand globally. At the national level the implementation of the scheme did not change much at the time of the low milk price. However, since 2011/12 the additional quota started to work as an advantage, as the total milk volume delivered exceeded the original accession quota. In 2012/13 in total 2,717.6 thousand tonnes of milk were delivered for processing, which is 94.2 per cent of the national delivery quota for that year. The return on cost is closely related to the milk price development and the price peaks are more or less accompanied by profitability peaks in the Czech Republic. The sample of farms under economic observation numbers around 180 which is considered to be a representative sample for the national average. Returns on cost without government payments have not been positive since 2005. Except for the extraordinarily difficult year of 2009, the return on cost was usually between zero and minus 10 per cent. Government payments usually improve the return on cost by about 10 percentage points, so that the return on cost becomes positive on average. A more detailed analysis shows that around the average figures a wide spectrum of results is included, which shows quite different picture. At least one third of farms showed a positive return on cost even without any government support.

Figure 14: Utilisation of the milk quota in the EU Member States, 2013/2014 quota year.

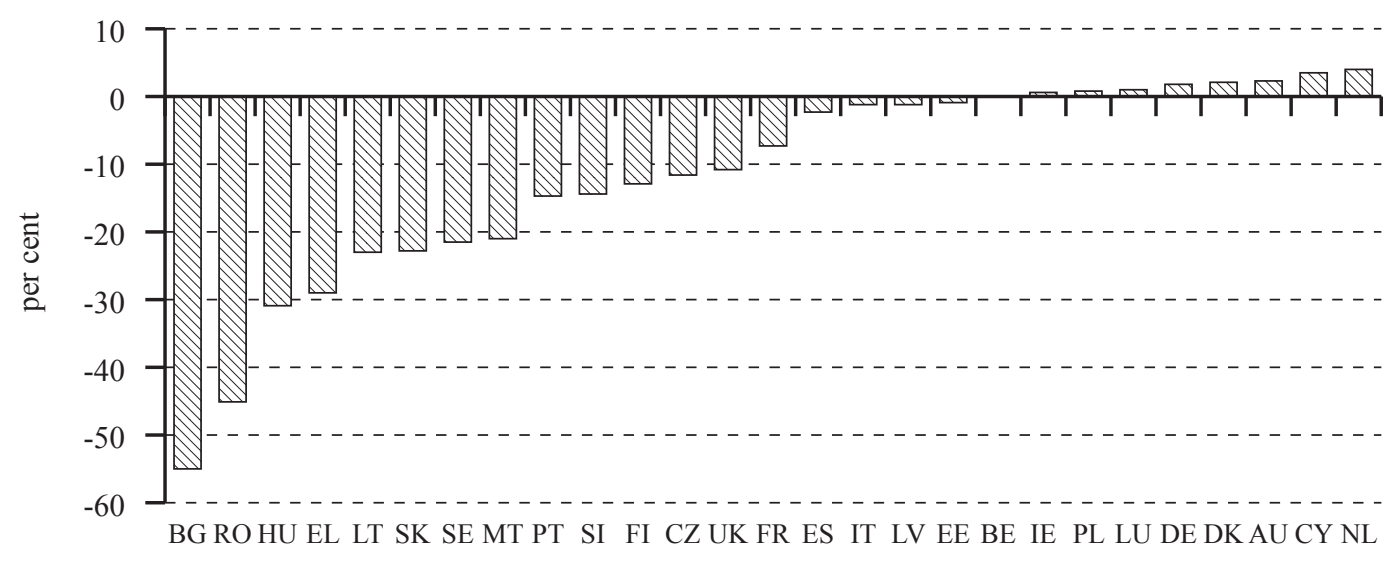

Source: EC

Since 2004 the EU regulations have been applicable in the Hungarian milk and dairy products market. Hungary negotiated a national quota of 1,947,280 tonnes (the requested quota amounted to 2.8 million tonnes), which included wholesale trade (delivery to dairy industry) of 1,782,650 tonnes, direct sale of 163,630 tonnes and a restructuring reserve of 42,780 tonnes to be used from the marketing year 2006/2007. The national reference fat content was 3.604 per cent by mass. At the end of the quota year 2013/2014, Hungarian producers had 1,957,288 tonnes of delivery quota and 176,116 tonnes of direct selling quota. The utilisation of the quota for delivery amounted to 1,415,508 tonnes and that of the quota for direct sales by producers to 59,491 tonnes. The rate of utilisation of the national quota amounted to around 69 per cent and, within it that of the quota for processing was only 72 per cent, showing that growth is not obstructed by the quotas at national level. Between the mar- 
keting years of 2004/2005 and 2013/2014, direct sales have increased by 150 per cent, thus the utilisation rate of this quota has increased from 15 to 34 per cent. From 2005, Hungarian milk producers received top-up payments linked to production from national funds, the so-called dairy premium. As from 2007 this support has been decoupled from production on a historical basis (the milk quota of 31 March 2007). The profitability of Hungarian milk production was favourable in recent years, due to the high milk prices and the high levels of financial support (Szajner and Vöneki, 2013). Since EU accession, milk production direct payments have continuously increased. Thus Hungary is the Member State with the highest direct support among those which joined the EU in 2004. Also the outlook regarding the support of the Hungarian milk production is very favourable.

\section{Conclusions}

Although the share of the EU's milk production was only 0.6 per cent in Slovakia, 1.0 per cent in Hungary and 1.8 per cent in the Czech Republic, the milk sector is of great importance to the three countries. Slovakian milk production accounts for about 13 per cent (2013) of the total agricultural production value and this share is about 8 per cent for Hungary and 18.2 per cent for the Czech Republic. Slovakia's milk production has significantly decreased since 2003. In the Czech Republic production has fluctuated at about the same level between 2003 and 2013 while in Hungary production has almost continuously declined during this time period. Self-sufficiency moved round 100 per cent in Slovakia and Hungary and 125 per cent in the Czech Republic.

Milk production is highly concentrated in these countries. In Slovakia the sector is dominated by medium and large sized farms with more than 100 dairy cows. In the Czech Republic farms with fewer than 50 heads almost disappeared in recent years. The cow herd is highly specialised and concentrated, as it is in Hungary, dominated by large agricultural enterprises. There are differences in the quality parameters of milk. The milk in the Czech Republic has the highest protein and fat contents while the lowest values are produced in Hungary. Marketing and production organisations play relatively important roles in Slovakia and the Czech Republic. In the contrary, in Hungary only a small proportion of milk is handled by these organisations despite progress in recent years.

In Slovakia, a decline in the number of enterprises implied increasing milk industry concentration. Milk purchase from farmers fell significantly but domestic market supply increased almost by a third since 2003 . The total profit/loss of the milk industry was prevailingly negative in the monitored period, even though two thirds of enterprises were profit-making. The main reason for unstable profits is volatility of milk prices and the increased import of milk products. In the Czech dairy industry, the structural shift shows three main effects. Firstly, the reduced number of processing units in the country, secondly, the inclusion of German processing plants in the processing network and, finally, the entry of foreign capital investments into the domestic industry. Milk processing concentration is relatively high in Hungary. However, the number of processing plants has increased while average procurement has declined. While there have been remarkable investments made in the past five years in Hungarian milk production, the processing industry - except for a few examples - has lagged behind. Raw milk prices in Slovakia, the Czech Republic and Hungary were among the lowest in the EU.

Consumption of industrial milk and dairy products in Slovakia, the Czech Republic and Hungary is 2-3 times lower than the EU average. In Slovakia, the average consumer expenditure on dairy products is about 17 per cent of total food expenditure while in Hungary this share amounts to about 14 per cent and in the Czech Republic about 18 per cent. For the short term, no major changes are foreseen in dairy product consumption in these countries. Owing to the low purchasing power, consumption remains at a moderate level; however, growth and development opportunities exist. Since 2009 , Slovakia has been a net importer of all milk products except liquid milk which is mainly raw milk exported to Hungary, the Czech Republic and Germany. Nonetheless, Slovak cheeses remain 
one of the crucial export commodities for their high quality. The Czech Republic is a net exporter of milk products. However, one of the most distinct trends visible is a more than 300 per cent increase in milk products imports, while exports have increased only by about 34 per cent since 2003, predominantly due to an increase in raw milk exports. Since 2004, Hungary has been a net importer of milk and dairy products, both in volume and in value. However, Hungary has a strong positive trade balance in raw milk and a slight positive trade balance in whey.

After the abolition of the quota system the EU is expected to produce more milk. Production is likely to be higher in those Member States where it already approximates to or exceeds the limit. Milk production, in the long term, is expected to shift to countries with high precipitation and high grass yield (where fodder production is inexpensive), boosting the flow of milk and dairy products from North to South and from West to East. In the medium term the more intense competition and the territorial realignment might redraw the structure of the EU milk market with raw material production taking place in cost efficient regions, and processing being carried out in regions with wellstructured markets.

From the analysis it is clear that the competitiveness of the Slovak milk sector has considerable reserves. To improve it, at the farm level it is necessary to make a profit - to reduce milk production costs especially via improving of cow yields that could be achieved inter alia by the use of sequential recovery of genetic resources. At the processing industry level it is necessary to boost the competitiveness of Slovak milk products not only on domestic but also on foreign markets, mainly through affordable, innovative products.

The relationships within the dairy supply chain can be considered as the weakness of the Czech dairy industry, partly because of missing forward integration between dairy farmers and processors. The incentives to the dairy industry should focus more on contracting. The bargaining power of dairy farmers should be bolstered by concentration of dairy farmers into fewer and more powerful producers' organisations. It is also necessary to strengthen the position of processors toward retailers and to continue supporting consumer education about the quality of Czech dairy products.

The weakest point in the Hungarian supply chain, with no doubt, is the processing industry. Investment is essential in order to increase the share of the high gross value added products at the processing stage. The competitiveness of the processors could also be boosted through cost reductions that could be achieved by the use of environmentally sound technologies which use less energy, improve the energy balance and utilise alternative energy sources. The most important challenges for the Hungarian dairy sector are the limited domestic demand for dairy products, the low profitability of milk production without high direct support and the low share of producer ownership in the processing subsector.

In the light of the quota abolition and the outlook on the dairy markets, intensification of competition can be expected. Hence, market opportunities will expand, of which the Member States with cost-effective production structures, competitive dairy sectors and effective, organised product chains will be able to take advantage. This could be an opportunity for Hungary to seize. The concentration, modernisation and selection processes that are taking place in Hungary might allow it to maintain or even slightly increase its raw milk production in the future. Taking into account the favourable conditions for milk production in Hungary, maintaining current export levels in the medium term is feasible. Hungarian prices are still competitive compared to the EU as a whole. However, it cannot be a long-term strategy for Hungary only to supply raw milk to those EU Member States which are struggling with temporary shortages and quality issues. 


\title{
Efficiency of the Food Industry
}

\author{
FELKAI, Beáta Olga', SZÉKELYHIDI, Katalin', \\ JANKUNÉ KÜRTHY, Gyöngyi', BELEŠOVÁ, Svetlana², MASÁR, Ivan², \\ MEZERA, Josef ${ }^{3}$ and NÁGLOVÁ, Zdeňka ${ }^{3}$
}

\section{Introduction}

Owing to the change of system in the CEECs at the beginning of the 1990s and also to their simultaneous accession to the EU, the Czech Republic, Slovakia and Hungary have historical, political and economic similarities. This provided the opportunity to compare the effect of EU accession on the development and the current economic and financial situations of the food industries of the three countries. We used primarily data from the period 2003-2013 and, in order to identify differences and similarities, both quantitative and qualitative analyses were employed.

Our analysis covered the general state of the food industries of the three countries, including their position in the national economy, their output, revenues, employment and their main financial results. Using secondary sources, we also examined the main branches, including their state and contribution to the food industry. Besides statistical analysis we used qualitative information and the results of interviews with industry participants in order to go beyond the data to obtain the views of producers. We tried to assess the technological situation of the industry as it is very important to examine what machines, equipment and production methods the food industry uses and how modern it is. We also analysed the local and export market opportunities of the market players, their innovation capabilities, their employment, their business relationships and cooperation with other participants, and generally what problems they face in the market. In addition to the supply side we looked at the demand side because it is essential to examine the purchasing power of consumers.

The study faced huge difficulties because the three research institutes use different methodologies and have access to different data. Moreover, they analyse the food industry according to different branches ${ }^{4}$. The differences between the indicators used made it difficult to compare the three countries $^{5}$. There are also differences in the periods examined ${ }^{6}$.

Despite the differences between the databases and methodology of the three countries, the weaknesses and opportunities of the food industry can be identified and the main characteristics of the situation can be compared.

\footnotetext{
Research Institute of Agricultural Economics, Budapest, Hungary.

National Agricultural and Food Centre - Research Institute of Agricultural and Food Economics, Bratislava, Slovak Republic.

Institute of Agricultural Economics and Information, Prague, Czech Republic.

4 For example the Czech Republic only analysed the manufacture of food products (Classification of Economic Activities - CZ-NACE 10) and the manufacture of beverages (CZ-NACE 11) while Slovakia highlighted the results of ten branches. On the other hand, Hungary dealt with the most important parameters of the food industry such as revenues, employment, share of foreign capital and financial results, underlining those branches that contributed the most to the general results of the industry. Both the Czech Republic and Slovakia characterised the food industry in less detail than Hungary, but Hungary did not analyse the branches separately. The branches used cannot be compared because Slovakia used branches that are not in the NACE classification in this form (for example canning, malt and brewing together, fat industry) so it is hard to decide what share of producers these cover and whether they represent the full market or not. This is important because Hungary used the NACE classification and the database of the Hungarian National Tax Office (NAV) of producers using double-entry bookkeeping, while the other two countries used data of their national statistical offices and the Ministry of Industry and Trade in case of the Czech Republic.

5 Hungary used output, revenue, export revenue, employment and a wide range of financial indicators such as Earning Before Taxes (EBIT), financial profit, indebtedness, Return on Sales (ROS), Return on Assets (ROA) and Return on Equity (ROE). Slovakia and the Czech Republic used value added indicators but these are also not comparable because of the differences in the population. Slovakia also used financial results in the analysis but with a different methodology and population (own products and services) than Hungary.

6 The Czech Republic analysed data between 2004 or 2005 and 2012 and Hungary analysed data between 2003 and 2012, but Slovakia could analyse the food industry only from 2005 because data are not available before then.
} 


\section{Role of the Sector}

In Hungary the output of the sector in current prices increased in the examined period, but its share in the national output declined (Figure 1) from 9.5 per cent to 6-7 per cent. This is because the growth in national output exceeded the growth of the food industry due to the performance of the chemical industry, the manufacture of fabricated metal products, the manufacture of machinery and equipment, trade and repair of vehicles. Employment in the sector decreased continuously until 2010, then it remained stable until 2012 when it increased by almost 2 per cent. Parallel to this the share of the sector's employment in the national economy's employment also grew but it is still well below the 6 per cent measured in 2003. The decline of the food industry's share in the national economy covered all examined parameters but after 2008 this trend came to an end and a slow increase can thereafter be observed.

Figure 1: Share of the food industry in the national economy in Hungary, 2003-2013.

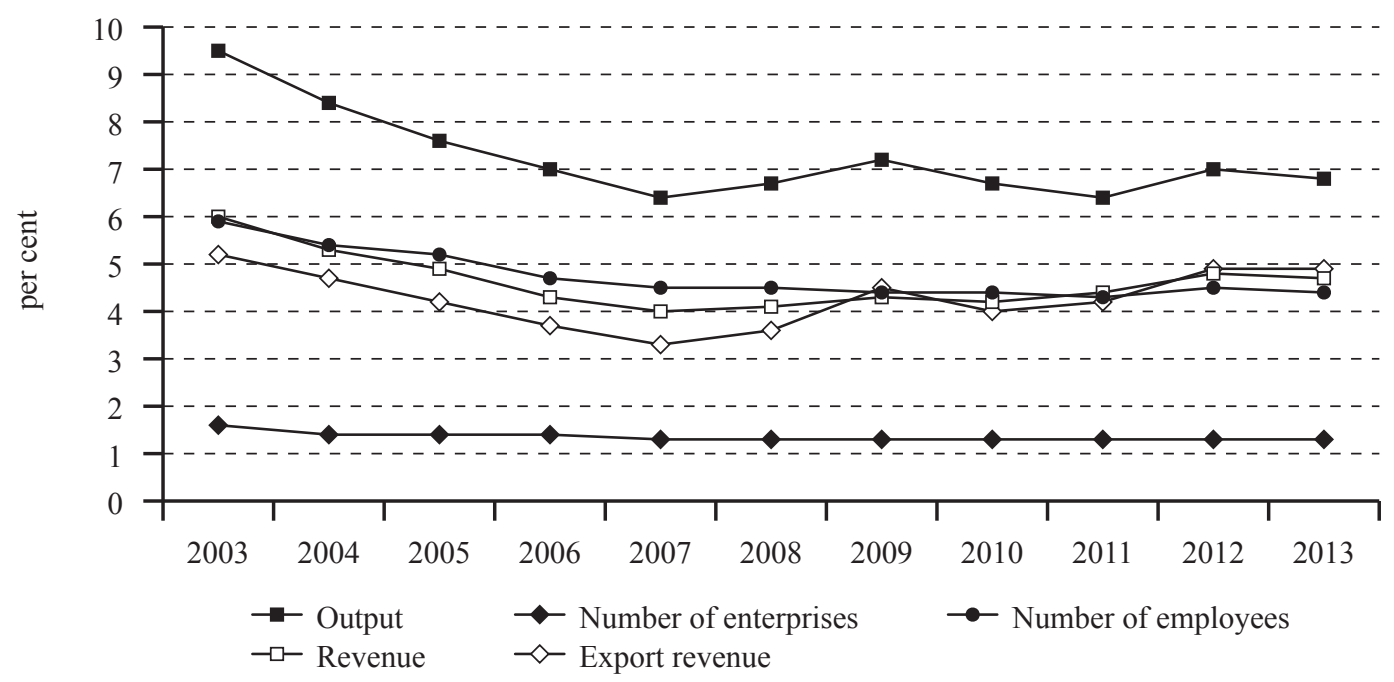

Source: Food Chain Analysis Department of AKI based on NAV data

Total and export revenue of the sector increased year by year except for a halt in 2009 but if inflation is taken into account when counting revenue, a 15 per cent decrease was experienced in the examined period instead of a 30 per cent increase excluding inflation (Table 1). Export revenue at current prices doubled and also grew at base prices by 40 per cent. The increase in exports is due to the changes in exchange rates, deeper knowledge of the export markets, higher willingness to meet foreign market needs and the narrowing of the domestic market. The decrease in the total revenue arises from several branches of the food industry: processing and preserving of meat, manufacture of dairy products, manufacture of feeds for farm animals, manufacture of tobacco products, other processing and preserving of fruit and vegetables and manufacture of oils. Revenue is influenced by companies with different accounting incomes. For example, in manufacture of tobacco products there are only a maximum of ten firms in each year while in the processing and preserving of meat almost 400 firms operate. The highest export revenues were reached by the processing and preserving of meat or processing and preserving of poultry meat and also processing and preserving of fruits and vegetables must be mentioned with regard to export revenue. 
Table 1: Main characteristics of the food industry in Hungary, 2003-2013.

EUR million

\begin{tabular}{|c|c|c|c|c|c|c|c|c|c|c|c|}
\hline Parameters & 2003 & 2004 & 2005 & 2006 & 2007 & 2008 & 2009 & 2010 & 2011 & 2012 & 2013 \\
\hline Output & 8,844 & 8,663 & 8,690 & 8,518 & 9,005 & 10,046 & 8,602 & 8,698 & 9,896 & 10,378 & 10,058 \\
\hline $\begin{array}{l}\text { Number of enterprises } \\
\text { (pcs) }\end{array}$ & 3,639 & 4,324 & 4,400 & 4,374 & 4,371 & 4,566 & 4,787 & 4,922 & 5,142 & 5,128 & 5,080 \\
\hline $\begin{array}{l}\text { Number of employees in } \\
\text { thousand persons }\end{array}$ & 124 & 119 & 113 & 105 & 100 & 99 & 96 & 95 & 95 & 96 & 94 \\
\hline Revenue & 9,982 & 9,785 & 9,959 & 9,548 & 10,145 & 11,355 & 9,886 & 10,028 & 11,271 & 11,779 & 11,358 \\
\hline Export revenue & 1,812 & 1,794 & 1,937 & 1,991 & 2,312 & 2,733 & 2,446 & 2,702 & 3,308 & 3,692 & 3,713 \\
\hline Operating profit (EBIT) & 389.2 & 159.5 & 243.3 & 273.3 & 201.1 & 225.2 & 342.3 & 319.2 & 337.4 & 244.6 & 333.9 \\
\hline Financial profit & -218.2 & -42.2 & -83.3 & -110.5 & -118.4 & -202.9 & -147.1 & -104.6 & -211.3 & -77.1 & -107.5 \\
\hline Extraordinary profit & 172.9 & 33 & 46.5 & 32.6 & 18.3 & 15.9 & -5 & 8.4 & 10.4 & 1.7 & 29.3 \\
\hline Earnings before taxes & 343.5 & 150 & 206.1 & 194.6 & 100.1 & 37.8 & 190.2 & 223 & 136.5 & 169.2 & 255.4 \\
\hline Balance Sheet Earnings & 131.6 & -99.4 & 11.7 & 54.1 & -14.7 & -207.7 & 1.8 & 4.7 & -70.6 & -23.2 & 61 \\
\hline Dividends paid & 191.5 & 274.8 & 165.3 & 204.1 & 77.5 & 207.7 & 195.9 & 220.1 & 175.1 & 170.2 & 205.2 \\
\hline $\begin{array}{l}\text { Share of fixed assets } \\
\text { (per cent) }\end{array}$ & 42.7 & 45 & 47.5 & 45.1 & 45.6 & 45.2 & 46.7 & 47.0 & 45.5 & 46.1 & 46.5 \\
\hline $\begin{array}{l}\text { Cover of fixed assets } \\
\text { (equity/fixed assets) } \\
\text { (per cent) }\end{array}$ & 99.1 & 108.7 & 116 & 115 & 124.9 & 130.4 & 124.5 & 124.1 & 130.6 & 127.8 & 119.2 \\
\hline $\begin{array}{l}\text { Share of equity in liabili- } \\
\text { ties (per cent) }\end{array}$ & 43.1 & 41.4 & 41 & 39.2 & 36.6 & 34.7 & 37.5 & 37.9 & 34.8 & 36.1 & 39 \\
\hline Indebtedness (per cent) & 53.5 & 54.9 & 54.7 & 55.3 & 59.1 & 60.9 & 58.1 & 58.5 & 61.5 & 60.4 & 57.2 \\
\hline $\begin{array}{l}\text { Debtors/creditors } \\
\text { (per cent) }\end{array}$ & 138.5 & 124.1 & 129 & 135.9 & 136.7 & 131.2 & 129.5 & 133.5 & 110.2 & 105.3 & 106.3 \\
\hline $\begin{array}{l}\text { Revenue per employee } \\
\text { (EUR thousand) }\end{array}$ & 80.8 & 82.5 & 88.2 & 90.7 & 101.1 & 114 & 102.9 & 105.8 & 118.8 & 122.2 & 121.1 \\
\hline $\begin{array}{l}\text { Operating profit per em- } \\
\text { ployee (EUR thousand) }\end{array}$ & 3.1 & 1.3 & 2.2 & 2.6 & 2.0 & 2.3 & 3.6 & 3.4 & 3.6 & 2.7 & 3.6 \\
\hline $\begin{array}{l}\text { Financial profit per em- } \\
\text { ployee (EUR thousand) }\end{array}$ & -1.8 & -0.4 & -0.7 & -1 & -1.2 & -2 & -1.5 & -1.1 & -2.2 & -0.9 & -1.1 \\
\hline $\begin{array}{l}\text { Earnings before taxes per } \\
\text { employee } \\
\text { (EUR thousand) }\end{array}$ & 2.8 & 1.3 & 1.8 & 1.8 & 1.0 & 0.4 & 2.0 & 2.4 & 1.4 & 1.9 & 2.7 \\
\hline Profitability (per cent) & 3.9 & 1.6 & 2.4 & 2.9 & 2 & 2 & 3.5 & 3.2 & 3 & 2.2 & 2.9 \\
\hline ROS (per cent) & 2.8 & 1.1 & 1.6 & 1.7 & 0.7 & 0 & 1.6 & 1.9 & 0.9 & 1.4 & 2.0 \\
\hline ROA (per cent) & 3.7 & 1.4 & 2.2 & 2.1 & 0.9 & 0 & 2.2 & 2.6 & 1.4 & 2 & 3.0 \\
\hline ROE (per cent) & 8.6 & 3.4 & 5.3 & 5.4 & 2.5 & -0.1 & 5.9 & 7 & 4 & 5.6 & 7.7 \\
\hline Liquidity (coef.) & 1.3 & 1.3 & 1.2 & 1.3 & 1.2 & 1.1 & 1.2 & 1.1 & 1.1 & 1.2 & 1.2 \\
\hline $\begin{array}{l}\text { Quick ratio (Acid Test) } \\
\text { (coef.) }\end{array}$ & 0.8 & 0.8 & 0.8 & 0.8 & 0.7 & 0.7 & 0.7 & 0.7 & 0.7 & 0.7 & 0.8 \\
\hline Cash ratio (coef.) & 0.2 & 0.2 & 0.1 & 0.1 & 0.1 & 0.1 & 0.1 & 0.1 & 0.1 & 0.1 & 0.1 \\
\hline
\end{tabular}

Source: Food Chain Analysis Department of AKI based on NAV data

The position of the Czech food industry expresses the share of employment in the manufacturing of food products and beverages of total employment for all economic activities, which during the period from 2004 to 2011 declined from 3.1 per cent to 2.5 per cent. This indicator was in 2011 higher in the Czech Republic (2.5 per cent) than in the EU 27 (2.1 per cent) and the EU 15 (2.0 per cent). The share of gross value added (GVA) for the manufacturing of food products and beverages in total GVA for all economic activities in the period from 2004 to 2012 declined from 3.3 per cent to 2.4 per cent. In 2012, the share of GVA of the food sector in the Czech Republic was higher than the same indicator for the EU 27 (2.0 per cent) and the EU 15 (2.0 per cent). After accession to the EU, the Czech food industry has been characterised by declining employment and declining share of GVA in 
the national economy. Food production in the Czech Republic between 2004 and 2012 increased by 32.6 per cent. The change in this indicator for the same period in the Slovak Republic was 38.2 per cent and in Hungary 13.0 per cent. According to MZe (2013), in the Czech Republic there were in 2013 total 8,432 enterprises (in CZ-NACE 10 and CZ-NACE 11 total). In CZ-NACE 10 there were 7,166 businesses and in CZ-NACE 11 there were 1,266 businesses.

Labour productivity in the food sector can be expressed by the annual GVA per 1000 employees. This indicator in the Czech Republic between 2004 and 2011 increased from EUR 18.1 million to EUR 27.7 million. The higher growth of this indicator (53.3 per cent) compared with growth in the EU 27 (8.0 per cent) was mainly due to a significant decrease in the number of employees in the Czech food industry. Despite this fact the the value of this indicator for the Czech food sector amounted to only 58.9 per cent of the figure for the EU 27 in 2011. The average gross monthly wage in the Czech food industry between 2004 and 2011 increased from EUR 474 to EUR 803.7. Although the growth of this indicator in the period was higher than in the EU 27 and EU 15, its value in the Czech food industry in 2011 is only 45.2 per cent of the value for the EU 27. Productivity and average monthly gross wage since the entry of the Czech Republic into the EU have grown faster than the same indicator for the EU 27. Owing to their low initial value at the time of entry into the EU, their values in 2011 are still much lower than the total data for the EU.

In 2013, exports of beverages and tobacco to the EU-28 increased by 10.2 per cent and achieved a positive balance of EUR 107.9 million. Exports of food and live animals grew by 5.9 per cent, but the balance was negative to the value of EUR 713.3 million. Since 2010, the biggest part in Czech food and beverages imports was comprised of groups CPA 10.8 Other food products (miscellaneous products), CPA 10.1 Preserved meat and meat products, and CPA 10.5 Dairy products. On the export side, in the long term, the most significant groups are CPA 10.8 Other food products, CPA 11 Beverages, and CPA 10.5 Dairy products (Pohlová and Mezera, 2014).

Foreign direct investment (FDI) in food, beverages and tobacco processing since EU accession peaked in 2012 at EUR 669.4 million. The fall in FDI between 2009 and 2010 was caused by the economic crisis. (Table 2). The volume of investments in fixed assets expressed per company in 2012 in the manufacture of food products was lower in the Czech Republic than in neighbouring countries (Mezera et al. 2014a).

Table 2: Inward food industry FDI in the Czech Republic, 2004-2013.

\begin{tabular}{lcrrrrrrrrr} 
& \multicolumn{10}{c}{ EUR million } \\
\hline Food and tobacco & $\mathbf{2 0 0 4}$ & $\mathbf{2 0 0 5}$ & $\mathbf{2 0 0 6}$ & $\mathbf{2 0 0 7}$ & $\mathbf{2 0 0 8}$ & $\mathbf{2 0 0 9}$ & $\mathbf{2 0 1 0}$ & $\mathbf{2 0 1 1}$ & $\mathbf{2 0 1 2}$ & $\mathbf{2 0 1 3}$ \\
\hline FDI & 6 & 91 & 129 & 255 & 297 & -93 & -528 & 132 & 669 & -134 \\
\hline $\begin{array}{l}\text { Index } \\
\begin{array}{l}100 \text { per cent }= \\
\text { previous year) }\end{array}\end{array}$ & - & $1,516.7$ & 141.8 & 197.7 & 116.5 & -31.3 & 567.7 & -25.0 & 506.8 & -20.0 \\
\hline
\end{tabular}

Remark: data on reinvested earnings and other capital have been included in FDI flows.

Source: Czech National Bank

In Slovakia the food industry as a whole achieved a higher profit in 2013 than in 2003 . Valueadded and labour productivity measured by value-added increased and the volume of bank credits declined by a quarter. Debt-equity ratio has declined. The share of domestic production in the Slovak food retail chain supply decreased from 78.9 per cent in 2003 to 45.9 per cent in 2013 . The dairy (20.7 per cent) and meat (13.5 per cent) processing industries predominate in the Slovakian food industry based on production volume, followed brewing-malting and bakery industry with their 9.6 per cent and 7.6 per cent shares of total food products output in 2013. The bakery, dairy, meat and wine industries are among the food branches with the lowest concentration level measured by the food products output indicator of the three largest producers (Table 3). 
Table 3: Main characteristics of the food industry in Slovakia, 2003-2013.

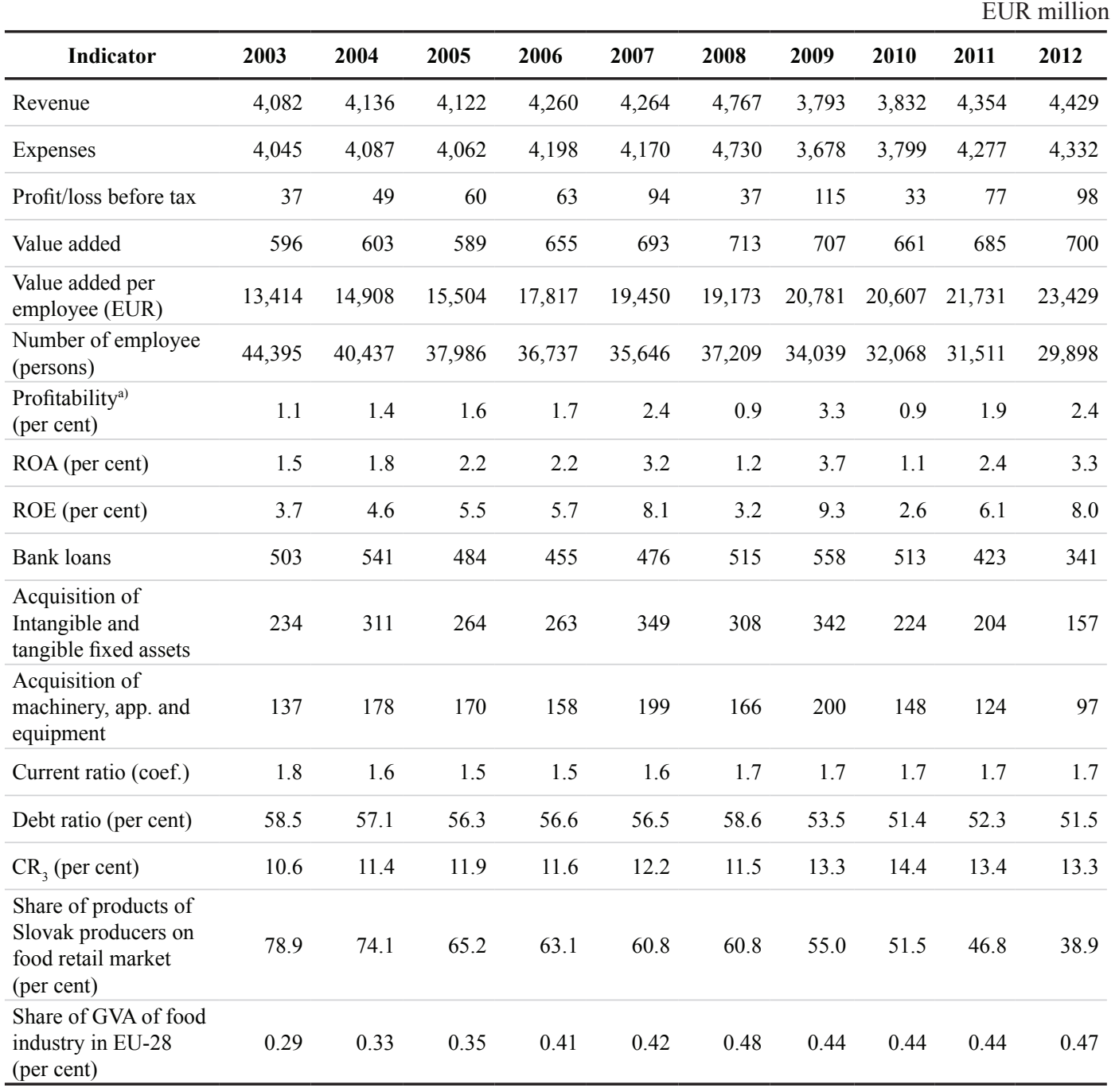

a) Revenue from the sale of own products, services and the sale of merchandise.

Source: MPVR of the SR, NPPC-VÚEPP, SO SR, Eurostat and NPPC-VUEPP

\section{The Financial Situation of the Sector}

In Hungary the sector's results showed significant changes year by year. Operating profit and the earnings before taxes are the most expressive parameters although they are related to each other, and they have fluctuated heavily. Profit was constantly negative, caused by high indebtedness (including the huge interest and redemption) and exchange rate changes. In 2008 the sector had only EUR 37.8 million in earnings before taxes caused by the financial loss which was over EUR 200 million in this year. The extremely high losses of the manufacture of cocoa, chocolate and sugar confectionary, manufacture of beer, production of meat products and other processing and preserving of fruit and vegetables, altogether account for almost half of the losses of the food industry. There are 1-3 companies in each of them which are responsible for the high loss of the branches. After 2008 the sector had profits similar to those in the years before 2008 due to lower prices of some agricultural raw materials. On the other hand, losses were a problem after 2008 and still remain so. 
We examined the results and their components using structural, efficiency, profitability and liquidity indicators. The share of fixed assets in the food industry did not change significantly in the examined period but it slightly increased through the decade. Its value reached an adequate level for production it should be higher. The value below 50 per cent is due to the high amount of receivables - mainly the high value of receivables from the delivery of goods and services. It is favourable if fixed assets are financed by the equity. Except for the first year the value of the cover of fixed assets indicator is over 100 per cent which means the financing of fixed assets is sufficient in the industry.

The share of equity in liabilities represents the holders' share in the capital and its increase is desirable. For the Hungarian food industry it decreased in the whole period, caused on the one hand by the decrease of the equity -by 5 per cent in ten years - while on the other hand liabilities increased by more than 10 per cent. It is critical if the indicator's value is below 30 per cent but this is not the case for Hungary. The above-mentioned high value of receivables can be observed in case of the debtors/ creditors share but its value is adequate over the period. The indebtedness of the food industry is very similar to that of the national economy for the processing industry including the food industry this value is remarkably high.

Examining profitability and efficiency, revenue per capita increased by more than 60 per cent from 2003 to 2012 in current prices. This increase derives from the slight rise in the revenue and the continuous decrease in the number of employees. Operating profit per employee fluctuated heavily due to the above-mentioned EBIT fluctuation and the continuously decreasing employee number did not improve the indicator's value. The situation is similar for the earnings before taxes per employee indicator from the opening value of EUR 2.8 thousand per capita it fell to EUR 0.4 thousand per capita by 2008. Since then it has increased but it did not reach the former value. The profit per capita is negative every year because of the losses of the food industry mentioned above but while in 2004 its value was EUR 0.4 thousand per capita in 2008 the loss per capita was more than EUR 2 thousand per capita.

Indicators using operating profit or earnings after taxes have positive values in all examined years. Values close to zero are the consequences of the EUR -3.6 million earnings after taxes reached in 2008. The sector has not been able to reach its 2003 value of profitability ever since. In 2009 the food industry had a fair year but since then a decreasing period started again because of the slightly increasing revenue and the stagnant operating profit. Indicators using earnings after taxes were the lowest in 2008 due to the high financial loss. Assets and revenue shaped in the same direction and with same scale in the period, so ROS and ROA had similar values The value of ROA indicators depend on the one hand on the valuation method and on the other hand enterprises may have rented assets which are not represented in the balance sheet. Owing to these the values of the indicators can be higher. Changes in ROE depend mainly on the earnings after taxes because they are not heavily influenced by equity fluctuations.

The usual liquidity rate of firms should be at least 1.3 but the Hungarian food industry could not maintain this value because the high amount of liabilities is due to the high share of current liabilities (typically 70 or sometimes more than 80 per cent). Quick ratio is used to evaluate how firms can cope with sudden financing situations. It divides the value of current liabilities by the amount of very liquid current assets (value without inventories). The expected value in Hungary is 0.7 , which the food industry could reach.

The operation of the sector highly depends on who are the owners of the capital. State property fell from 50 per cent at the beginning of 1990s so that by 2008 it did not even reach one per cent. Foreign capital has the highest share, and alongside it domestic joint ventures and domestic individuals are the most important holders. Since 2000 foreign capital has been continuously leaving the country and it is not being replaced by domestic capital. 
Nominal capital of the sector fell to 61.5 per cent in the examined period (Figure 2) due to the change in the share of foreign capital which decreased by almost half, but the share of domestic joint ventures also decreased by more than 30 per cent between 2003 and 2012. Other capitals such as state property, co-operative or monetary institution proper are not influential.

Figure 2: Composition of nominal capital in Hungarian food industry, 2003-2013.

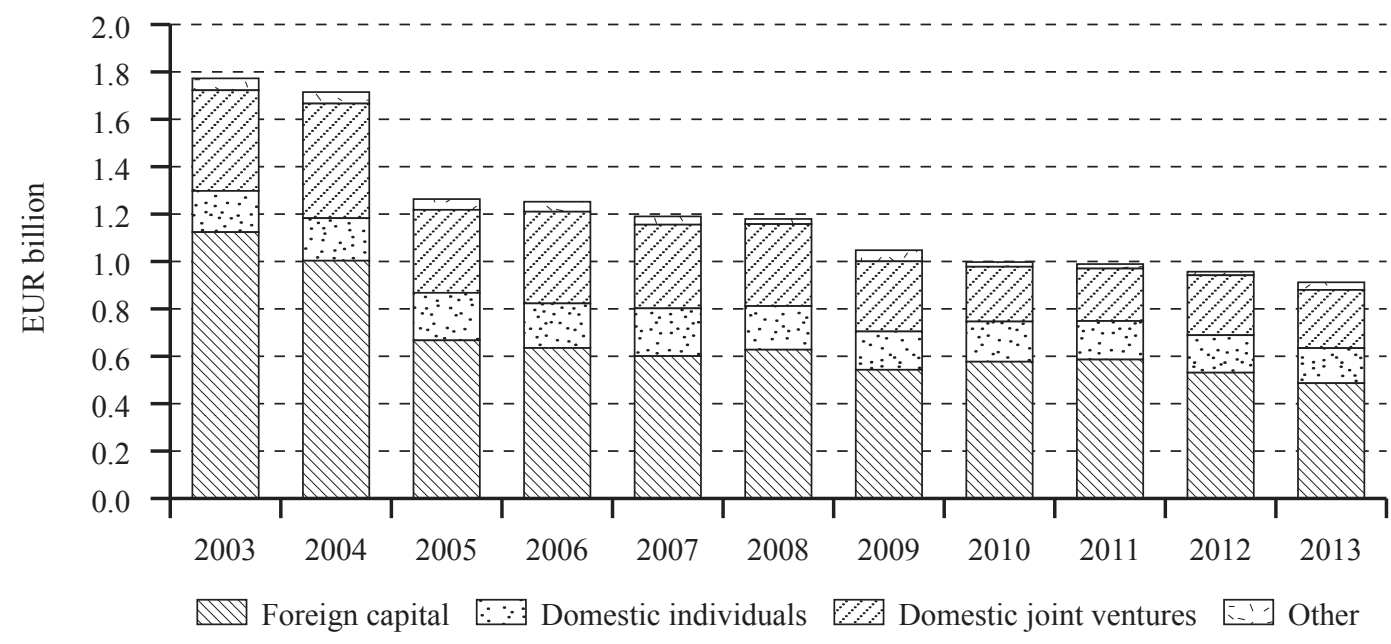

Source: Food Chain Analysis Department of AKI based on NAV data

Every year the amount of foreign capital is the highest in manufacture of soft drink and mineral waters, manufacture of beer, manufacture of cocoa, chocolate and sugar confectionary, manufacture of wine from grapes, production of meat products and manufacture of dairy products, but in a different order each year. The five branches with the highest foreign capital together cover more than half of the foreign nominal capital of the food industry. The capitals of the branches are frequently determined by one or two companies which are typically those with the highest revenue.

The share of foreign capital is more than 90 per cent in manufacture of beer, manufacture of prepared pet food, manufacture of ice cream, processing and preserving of potatoes and manufacture of cocoa, chocolate and sugar confectionary. There are typically 10-50 enterprises in these branches but only the performance a few of them are influential in the branches. The high share of foreign capital is due to the fact that the companies with the highest foreign capital are usually 100 per cent foreign owned. There are of course branches with no foreign capital, for example manufacture of other nondistilled fermented beverages or manufacture of fruit wine (at the end of the period).

Based on the data of companies with double-entry bookkeeping, the liabilities of the food industry are between EUR 3.9 and 4.6 billion in current prices. The liabilities are highest in the case of large companies and, among the branches, other processing and preserving of fruit and vegetables, processing and preserving of meat, preserving of poultry meat have the highest amount of liabilities. Every year, indebtedness is highest for smaller branches such as processing and preserving of fish, manufacture of ice cream and manufacture of malt. It was always higher than 50 per cent, and since 2007 it was always around 60 per cent which is very close to the value for the national economy. In the food industry, liabilities and balance sheet total changed in the same direction but the scales of their changes were different. The share of liabilities in equity increased significantly year by year, which is due to not only the increase in liabilities but also to the decrease of the equity. 
Figure 3: Number of enterprises in the food industry by SME categories in Hungary, 2003-2013.

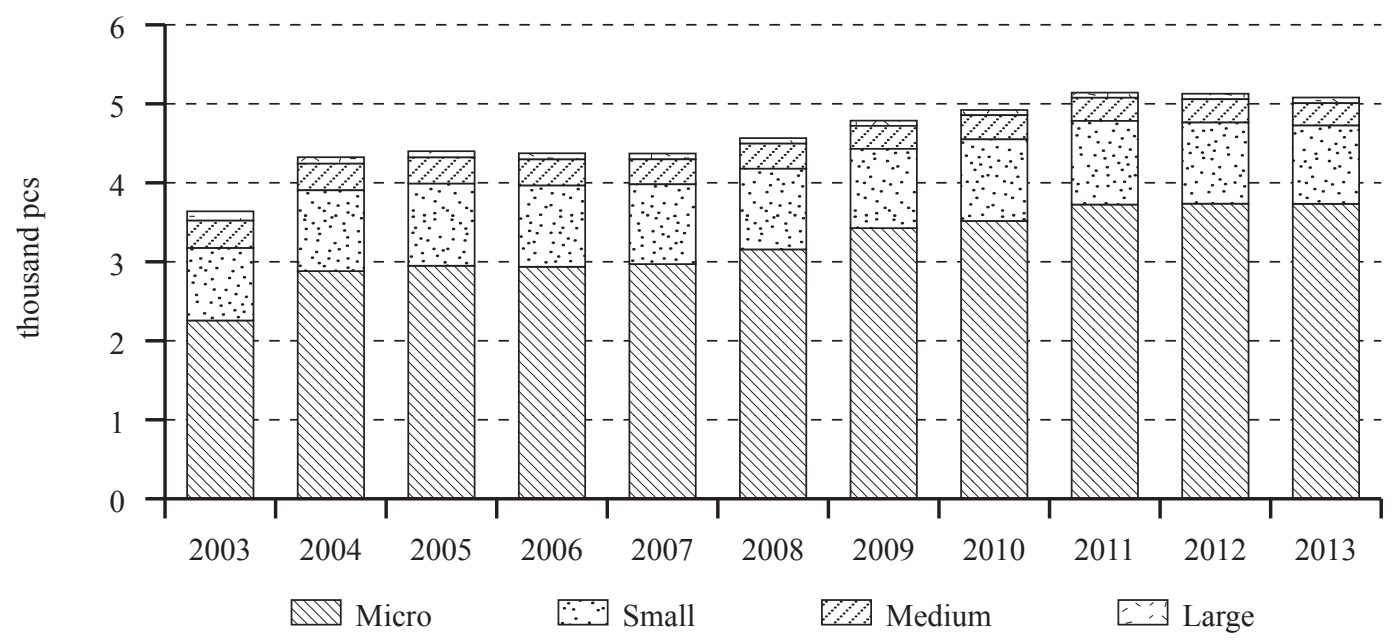

Source: Food Chain Analysis Department of AKI based on NAV data

The Hungarian food industry is characterised by a certain duality which is due to the fact that two thirds of companies are micro enterprises but the performance of the industry is determined by the large companies whose share is only 1-3 per cent in the industry. The number of companies in the food industry with double-entry bookkeeping increased by more than 30 per cent in the examined period. The number of medium-sized enterprises decreased by 17 per cent and the number of large companies halved. The number of micro enterprises grew by 60 per cent and the number of small enterprises increased by 10 per cent. There was a significant jump in the numbers in 2004 because of the changes in accounting rules due to Hungary's accession to the EU. These changes meant that new enterprises were to be established only by choosing double-entry bookkeeping and those previously using single-entry bookkeeping had to switch to double-entry bookkeeping.

The role of micro and small enterprises in employment increased: in 2003 they provided jobs for 20 per cent of the employees in the industry while in 2012this share was more than 30 per cent. This increase was also due to the closure of many large companies employing many people.

Although the number of large companies decreased in the examined period, their contribution to the revenue of the industry has not changed much since 2004. On the other hand, the role of small and medium-sized enterprises (SMEs) has increased. Export revenue also grew, in 2003 it was almost EUR 1.8 billion while by 2012 revenue from exports had almost doubled (EUR 3.3 billion) in current prices, and it increased by 30 per cent in base prices as well. The contribution of different sizes of enterprise to the export revenue has remained constant since 2004. The contribution of the large companies to the industry's total export revenue was about 65 per cent and that of medium-sized enterprises was 25 per cent . Micro and small enterprises each had a 5 per cent share.

The sector's results are best described by earnings before taxes, which are mainly characterised by the results of large companies. There is a strong relationship between the changes (both direction and scale) of large companies and the changes in the results of the industry. Medium-sized enterprises were becoming stronger and stronger after 2008 but their results had only a moderate effect on the overall result of the sector. 
The cause for the dominance of large companies can be the high share of foreign capital in their nominal capital. Companies in foreign ownership can afford investments for development and innovation and for better results (Kapronczai et al., 2009a). Foreign capital has not reached even 20 per cent since 2004; this share was 30-40 per cent for SMEs while there was more than 70 per cent foreign capital in large companies apart for two years (Figure 4). The time series of large and mediumsized companies are shaped in an opposite direction, due to the changes in the boundaries of the size categories year by year caused by exchange rate changes.

\section{Figure 4: Share of foreign capital in the food industry by SME categories} in Hungary, 2003-2013.

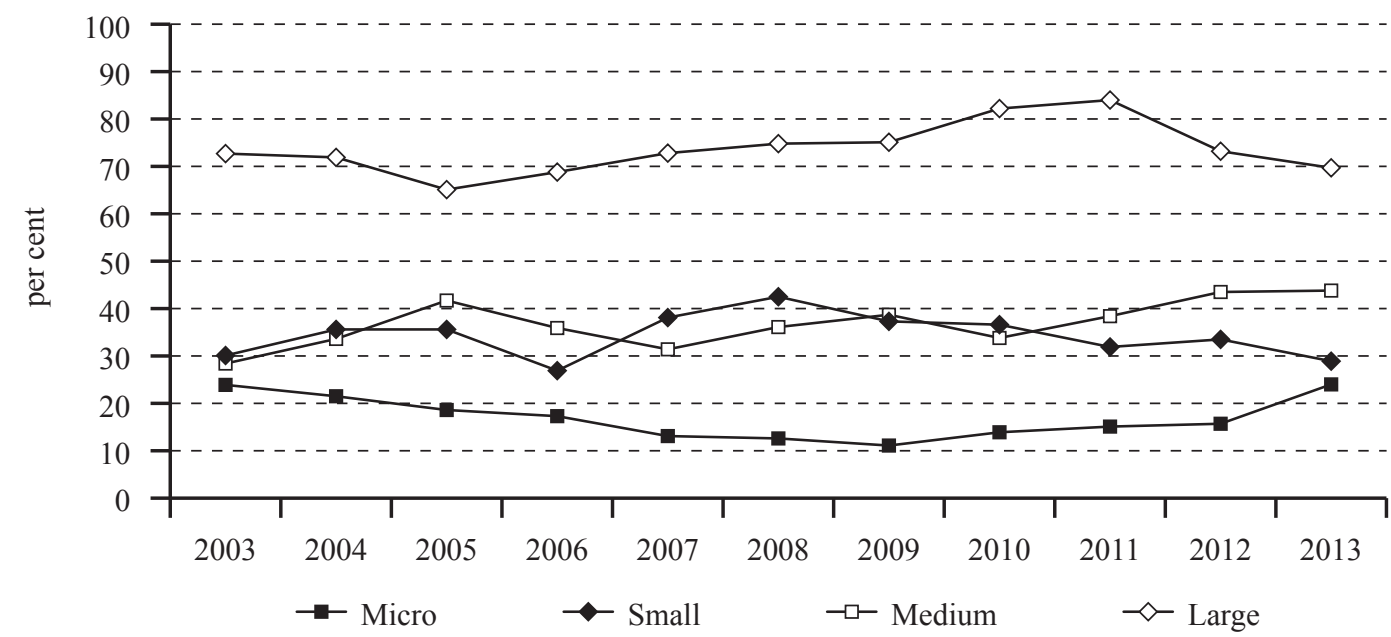

Source: Food Chain Analysis Department of AKI based on NAV data

In the Czech Republic, manufacture of food products is still an important sector in the context of the Czech processing industry. In 2013, revenues from sales of own products and services accounted for a 6.8 per cent share of the manufacturing industry. In the same year the indicator value added for this production contributed to the manufacturing industry 6.07 per cent and 8.29 per cent of employment. The the balance of foreign trade of food products in 2013 amounted to a negative value of EUR 1.07 billion while the beverage industry had a positive balance of EUR 0.08 billion.

Labour productivity in food processing measured as value added per employee increased between 2005 and 2013 by about EUR 5,612, i. e. 34.9 per cent of the value of 2005 . This increase was caused mainly by a 22,049 person reduction in the number of employees during the monitored period, i.e. 20 per cent of the figure in 2005. GVA increased for the nine-year period, but in 2012 it decreased due to a reduction in output including trade margins and increased costs. During the period from 2005 to 2012 the trend has been to reduce the number of persons employed in all food sectors.

Revenues grew in 2007 and 2008, but in 2009 and 2010 they fell due to the economic crisis. In 2011 , revenues grew by 3.5 per cent and in 2012 growth continued, reaching 3.9 per cent. The profitability of revenues during the period 2005-2013 increased only about 0.5 percentage points, to 2.5 per cent in 2013. The share of the profit margin on sales of goods in 2011 was 15.6 per cent for the whole trade sector (CZ-NACE 45, 46, 47). The development of the manufacture of food products indicators is shown in Table 4. 
Table 4: Main characteristics of manufacture of food products in the Czech Republic, 2005-2013.

EUR million

\begin{tabular}{lrrrrrrrrr}
\hline \multicolumn{1}{c}{ Indicators } & $\mathbf{2 0 0 5}$ & $\mathbf{2 0 0 6}$ & $\mathbf{2 0 0 7}$ & $\mathbf{2 0 0 8}$ & $\mathbf{2 0 0 9}$ & $\mathbf{2 0 1 0}$ & $\mathbf{2 0 1 1}$ & $\mathbf{2 0 1 2}$ & $\mathbf{2 0 1 3}$ \\
\hline Revenues & 10,524 & 10,968 & 11,976 & 13,435 & 11,995 & 11,732 & 12,489 & 12,686 & 12,212 \\
\hline Expenses & 10,318 & 10,779 & 11,727 & 13,217 & 11,694 & 11,393 & 12,180 & 12,414 & 11,823 \\
\hline Profit/loss after tax & 210 & 190 & 252 & 218 & 301 & 339 & 308 & 272 & 310 \\
\hline $\begin{array}{l}\text { Profitability of } \\
\text { revenue (per cent) }\end{array}$ & 2.0 & 1.74 & 2.11 & 1.62 & 2.51 & 2.89 & 2.47 & 2.14 & 2.54 \\
\hline $\begin{array}{l}\text { Value added } \\
\text { Value added per } \\
\text { employee (EUR) }\end{array}$ & 1,532 & 1,588 & 1,780 & 1,960 & 2,033 & 1,983 & 2,049 & 1,829 & 1,892 \\
\hline $\begin{array}{l}\text { Number of } \\
\text { employee (person) }\end{array}$ & 109,218 & 104,132 & 102,690 & 99,376 & 96,587 & 92,586 & 90,170 & 89,914 & 87,169 \\
\hline
\end{tabular}

Source: CZSO, MZe and IAEI

For the manufacture of beverages in the Czech Republic, the sales of own products and services have reached a 1.7 per cent share of the value of manufacturing industry. The share of value added in manufacturing industry in was 2.3 per cent and the share in employment was 1.3 per cent in 2013 . Labour productivity increased in this production between 2005 and 2013 more than in the production of food products. Growth was about EUR 9.7 thousand per employee, (i.e. 22.8 per cent of the value of 2005). Productivity in this sector has increased year on year, with the exception of 2010, when productivity decreased as a result of the reduction in the volume of value added. In 2013 this indicator reached EUR 54.2 thousand per employee (i.e. an annual increase of 4.3 per cent). The negative trend in the volume of value added has stopped and 2012 showed an annual increase of 2.8 per cent. Over the period 2005-2013 the number of employees decreased by 3,391 (i.e. 20.1 per cent of the value of 2005). Revenues in this production began to rise in 2012 after falling in 2009 and 2011. In 2013 revenues reached a moderate annual growth of about EUR 52.3 million (i.e. 2 per cent). The profitability of revenues decreased from 10 per cent in 2005 to 5.5 per cent in 2012 as a result of the increasing costs of production. The average value of this indicator during the reporting period was 7.9 per cent. The growth rate of labour productivity as an increase in value added per employee for the period 2005-2013 is lower in the beverage industry (an increase of 21.8 per cent from the 2005value ) than in the manufacture of food products (an increase of 34.9 per cent from the 2005 value, i.e. about EUR 5,612 per employee). While in the period 2005-2012 the profitability of revenues of manufacture of food products increased from 2 per cent to 2.1 per cent, for manufacture of beverages it decreased from 10 per cent to 5.5 per cent due to an increase in costs.

Table 5 summarises the most important financial indicators of the food industry in the Czech Republic according to different branches. The profitability of revenues of different branches was calculated as the ratio profit or loss to total revenues in per cent. This indicator was assessed for the period 2005-2013 in the same field of food businesses and at the same enterprise size. The highest increase in this indicator (3.1 per cent) was recorded for manufacture of other food products. Production with the highest value of this indicator in 2013 was the manufacture of beverages (5.4 per cent). The lowest value in the same year was in processing and preserving of meat and production of meat products ( 0.6 per cent). For the period 2005-2013 in the manufacture of food products the largest decline was in the profitability of revenues of small enterprises (10-49 employees) and the largest increase in this indicator occurred for medium-sized companies (50-249 employees). The highest absolute values for this indicator in 2012 were achieved by micro-enterprises (0-9 employees). In the manufacture of beverages, the largest decline in the profitability of revenues of small enterprises which also recorded the lowest absolute value of this indicator in 2012. The highest absolute value 
in 2012 was achieved by large enterprises (more than 250 employees). For both sectors the biggest decline in the profitability of revenues for the period 2005-2012 was in the category of small enterprises.

Table 5: Main financial indicators of food industry branches in the Czech Republic, 2005-2013.

\begin{tabular}{|c|c|c|c|c|c|c|c|c|c|c|c|c|}
\hline \multirow[t]{2}{*}{ Branch } & \multicolumn{3}{|c|}{$\begin{array}{c}\begin{array}{c}\text { Profitability of } \\
\text { revenues }\end{array} \\
\text { (per cent) }\end{array}$} & \multicolumn{3}{|c|}{$\begin{array}{l}\text { Share of sales of } \\
\text { own products } \\
\text { (per cent) }\end{array}$} & \multicolumn{3}{|c|}{$\begin{array}{l}\begin{array}{c}\text { Value added per } \\
\text { employee }\end{array} \\
\text { (EUR thousand) }\end{array}$} & \multicolumn{3}{|c|}{$\begin{array}{c}\text { CR-3 } \\
\text { (per cent) }\end{array}$} \\
\hline & 2005 & 2013 & Chg & 2005 & 2013 & Chg & 2005 & 2013 & Chg & 2005 & 2013 & Chg \\
\hline $\begin{array}{l}\text { Meat and meat } \\
\text { products }\end{array}$ & 1.1 & 0.6 & -0.5 & 26.0 & 22.7 & -3.3 & 11.7 & 15.4 & 114.6 & 13.8 & 21.0 & 7.1 \\
\hline $\begin{array}{l}\text { Fish, crustaceans } \\
\text { and molluscs }\end{array}$ & 3.4 & 0.6 & -2.8 & 0.7 & 0.8 & 0.1 & 15.4 & 21.9 & 123.6 & & & \\
\hline $\begin{array}{l}\text { Fruit and } \\
\text { vegetables }\end{array}$ & 2.9 & 3.3 & 0.4 & 3.1 & 2.4 & -0.7 & 15.0 & 19.2 & 111.3 & 24.4 & 37.3 & 12.1 \\
\hline $\begin{array}{l}\text { Vegetable and } \\
\text { animal oils and fats }\end{array}$ & 2.7 & 1.0 & -1.7 & 7.6 & 6.5 & -1.1 & 25.1 & 41.9 & 145.5 & 46.8 & 86.7 & 39.9 \\
\hline Dairy products & 0.9 & 3.4 & 2.5 & 18.6 & 17.8 & -0.8 & 14.2 & 28.1 & 172.9 & 32.3 & 28.7 & -3.6 \\
\hline $\begin{array}{l}\text { Grain mill and } \\
\text { starch products }\end{array}$ & 2.7 & 0.9 & -1.8 & 4.2 & 4.4 & 0.3 & 16.9 & 23.3 & 120.3 & 17.8 & 22.7 & 4.1 \\
\hline $\begin{array}{l}\text { Bakery and farina- } \\
\text { ceous products }\end{array}$ & 5.1 & 0.7 & -4.4 & 14.5 & 12.2 & -2.4 & 10.4 & 13.3 & 111.0 & 11.7 & 24.2 & 12.1 \\
\hline $\begin{array}{l}\text { Other food } \\
\text { products }\end{array}$ & 1.5 & 4.6 & 3.1 & 17.2 & 19.4 & 2.3 & 20.6 & 31.1 & 131.7 & 29.0 & 33.3 & 4.1 \\
\hline $\begin{array}{l}\text { Prepared animal } \\
\text { feeds }\end{array}$ & 1.7 & 4.7 & 3.0 & 8.2 & 13.9 & 5.9 & 21.2 & 60.4 & 247.9 & 15.0 & 39.5 & 24.1 \\
\hline Food products total & 2.0 & 2.5 & 0.5 & 100.0 & 100.0 & - & 14.0 & 21.7 & 134.9 & - & - & - \\
\hline Beverages & 10.0 & 5.4 & -4.6 & - & - & - & 38.8 & 54.2 & 121.8 & 36.6 & 36.8 & 0.2 \\
\hline Food and bev. total & 3.4 & 3.6 & 0.2 & - & - & - & - & - & - & - & & - \\
\hline
\end{tabular}

Source: Ministry of Industry and Trade of the Czech Republic

Manufacture of prepared animal feeds had the largest increase (5.9 percentage points) for the period from 2005 to 2013. This indicator decreased the most (by 3.3 percentage points) in the production of meat and meat products. The greatest growth in labour productivity was achieved by the production of prepared animal feeds due to high growth in sales of own products and services and the declining number of employees.

CR was calculated as a proportion of sales of own products and services for the three largest companies in the branch of total sales in the branch (in years 2008 and 2013). The biggest increase in this indicator in the period 2008-2013 was in manufacture of vegetable and animal oils and fats, from 46.8 per cent to 86.7 per cent. In the manufacture of dairy products the CR decreased by 3.6 percentage points. Between the years 2008 and 2013 there was an increasing level of concentration that ranges in 2013 by branch from 21.0 per cent to 86.7 per cent in most food industries. Only in manufacture of vegetable and animal oils and fats, this indicator exceeded 80 per cent. Other food branches have recorded low concentration ( 0 per cent to 50 per cent).

In Slovakia the detailed financial analysis was carried out according to the different branches of the sector. In the industry profit has developed variably in the dairy branch, and most years were loss-making although the level of loss was lower in past years compared to 2003-2005. In term of production output size, dairy is largest production branch with 20 per cent share of total food production. Value-added volume development was favourable with an increase from EUR 42-59 million in 
the period 2003-2006 to EUR 96 million in 2013. The number of employees is decreasing along with growth of labour productivity measured by value-added. Despite this the labour productivity is moderately below the food industry average although its level has increased more than twice compared to 2003-2004. The debt ratio indicator significantly exceeded the level in the Slovak food industry although since 2009 an improvement arose to average level (apart from in 2011). Available financial sources expressed by current ratio achieved a coefficient of 1.5 in 2013 and it increased compared to the period 2004-2007 but it is still below the average for the food industry (1.7). Dairy is characterised by a more important share of procuring long-term tangible and intangible assets (investments), of which 56-65 per cent was for the purchase of machines and technologies. CR of production increased from 30.1 per cent in 2003 to 45.7 per cent in 2013 and it has been growing moderately in the past three years. The weakness of dairy is that the share of domestic production declined from 92.1 per cent in 2003 to 62.8 per cent in 2013 , caused notably by finished goods imports.

Even though the meat processing industry is the second largest concerning the share of food products in the total food industry in the Slovak Republic, its position has declined during the period under review. While in 2003 the sector recorded a profit EUR 11 million, it was continuously loss making between 2010 and 2012 before generating a profit of EUR 2 million in 2013. Investment activity declined from EUR 46 million to EUR 14 million. Except for the period 2004-2006, more than half of financial resources were used for purchasing machines. More consolidated value-added volume declined slightly in 2013. The debt ratio indicator (58.8 per cent in the year 2013) substantially exceeds the level in the Slovak food industry. The values of current ratio indicator were below food industry average. Food products output concentration increased from 39.7 per cent in 2003 to 47.1 per cent in 2013 yet the concentration indicator is still low. The share of production of domestic meat producers in the Slovak retail chain is gradually declining. While in the period 2003-2004 it fluctuated between 78 and 85 per cent, later it declined below 60 per cent. After 2009 it did not even achieve 50 per cent and it represented only 36.5 per cent in 2013.

The losses of the poultry industry were the highest in 2008 at EUR 10 million, but have decreased in the past few years to EUR 1 million The number of employees has declined by more than half, which influenced labour productivity measured by valueadded, which increased particularly in last years. Labour productivity was 85 per cent higher in 2013 than in 2003. Value-added conversely increased by 6 per cent. Factories have invested less, thereby total investments declined by up to 61 per cent. The debt ratio indicator worsened from 45.6 per cent in 2003 to 67.3 per cent in 2013. Since 2006 it has continuously exceeded the average level of the Slovak food industry. Rising indebtedness resulted in a drop in assets due to falling production. Moreover, current ratio values (1.2 and 1.3 respectively) are below the level of the food industry (1.8). Until 2006 the poultry industry had a medium production CR. Later its concentration increased and stabilised at 85 per cent in 2012, a high level of concentration. Domestic poultry producers gained just a 33.8 per cent share in the the Slovak retail chain in 2013, compared to 84.2 per cent in 2003.

Profit in the milling industry in Slovakia ranged between EUR -2 and 2 million in the examined period except for 2008 (EUR 5 million) and 2013 (EUR 8 million). There were no significant fluctuations in achieving value-added although its volume was lowest (EUR 14 million) in the last year. As the number of employees declined the labour productivity measured by value-added grew. The current ratio indicator exceeded the average level of the food industry, with 2013 being an exception. In terms of debt ratio (indebtedness) the situation was less favourable because the indicator was higher than the average of the food industry. Until 2008 the branch had a low concentration level that later became a medium level. The three largest millers produced 66 per cent of the volume of food products. In 2013 Slovak milling products comprised 44.7 per cent of the domestic retail market whereas during the years 20032004 the figure was close to 90 per cent. 
Bakery is the lowest concentrated industry among all food branches in terms of food products output. Even so, the concentration level has increased from 16.6 per cent in 2003 to 35.7 per cent in 2013. The sector's losses gradually and moderately increased between 2008 and 2012 and reached EUR -12 million in 2012. By 2013 the loss decreased to EUR -2 million. Labour productivity measured by valueadded has increased, along with a slower decline in the number of employees compared to some other branches. The current ratio indicator worsened and it is significantly below the average level of the food industry in Slovakia. The debt ratio indicator has also moved in a negative direction and also exceeds the average level of food industry. The share of domestic bakery products in the domestic retail market declined to just 34.6 per cent in 2013.

Despite a long period of generating positive economic results, albeit at a lower volume, the fat industry operated at a loss during the last two years, with a year-to-year increasing of the loss from EUR 4 million in 2003 to EUR 17 million in 2012. There is a long-term decline in value-added volume. The number of employees declined by half as did labour productivity measured by value-added since 2009. Fat industry, except for declines in last two years, has favourable current ratio indicators but since 2008 the debt ratio indicator significantly deteriorated, caused by a partial drop of assets. Despite this the branch maintains one of highest CRs. The share of food products made by domestic producers in the Slovak retail chain has declined from 48.1 per cent in 2003 to 32.0 per cent in 2010 (data for the last three years are unavailable).

The malting and brewing industry has generated a lower level of net profit but the volume increased mainly during last two monitored years. In 2003 its profit was EUR 0.4 million and it increased to EUR 32 million by 2013. The value-added volume did not register any extreme fluctuations and since 2009 growth has mainly been rising. Labour productivity measured by value-added grew by 58 per cent compared to 2003 . The level of profitability was favourable in the last three years. The volume of bank credits fell significantly and the debt ratio indicator also decreased (after 2013). The current ratio of the branch is also not a marked weakness as it approaches the average level of the food industry. Malting and brewing industry were always characterised by high concentration level which increased after 2003. The share of food products made by domestic producers at retail market was 79.3 per cent in 2013, despite a 14.0 percentage point decline from 2003.

The net profit of the canning industry was between EUR 9 and 17 million in the examined period Value-added volume and labour productivity measured by value-added increased. Profitability reached significant values but declined. Employment increased and declined over time with an overall increase compared to 2003. The current ratio indicator was above the average values of the food industry. Despite moderate deterioration (increase) in the previous year, debt ratio fell below the average level of the food industry. The canning industry was initially a highly concentrated branch but after 2008 the level of concentration was decreased. The share of food products made by domestic producers tended to decline and in 2013 it reached 30.3 per cent.

The confectionery industry achieved a net profit with tendency of growth until 2011 when it reached a value of EUR 28 million, but it decreased to EUR 12 million by 2013. Profitability, valueadded and labour productivity increased but the number of employees declined modestly. Current ratio was above the average level of the food industry but declined up to 2012. Debt ratio declined and simultaneously its values were the lowest among all food branches. Concentration of production declined from 90.1 per cent in 2003 to 72.6 per cent in 2013. The share of food products made by domestic producers supplied to the Slovak retail chain fluctuated substantially but showed signs of decline.

The wine industry achieved lower volumes of net profit, its value was between EUR 1 and 10 million in the examined period, EUR 10 million was measured in 2011. The decline in the number of employees stopped in 2010 and employment was higher in the next two years. The decline in 
employment corresponded with labour productivity growth except in 2012 when it decreased. Debt ratio was one of the lowest among all branches assessed in this analysis and below the average of the food industry. The declining debt ratio a is positive factor. Current ratio is above the average of the food sector. Concentration was 50.3 per cent in 2003 and 49.6 per cent in 2013). The share of wine products made by domestic producers in the Slovak retail chain declined from 84.4 per cent in 2003 to 46.1 per cent in 2013.

\section{Qualitative analysis of the food industry sector}

In Hungary the food industry was examined not only using statistical data but also through interviews with enterprises operating in the industry. The structured questionnaire covered the whole food chain and its main concept was based on the research of Kapronczai et al. (2009b). Furthermore we applied the work of other researchers. Györe et al. (2009) had already examined sales and logistics, Juhász et al. (2010) looked at the role of private labels, while Darvasné et al. (2014) dealt with the reputation of trademarks and geographical indications. The shadow economy, which we also examined, has been the subject of much research such as that carried out by Tanító et al. (2013).

There are 5,000 enterprises in the Hungarian food industry but the performance of just 100 of them determines the results of the sector, so when we evaluate the sector's performance we should focus on these companies. We must also take into account the fact that the operation of many of these companies concerns other sectors (in most cases trade) besides processing. We examined the most important sub-sectors/branches and selected our interviewees from among them, choosing a representative sample by enterprise size.

A success factor of the sector is the adequate quality and quantity of raw materials. The relationship with business partners is typically based on trust. Long-term cooperation is the main aim of producers but sometimes there are negative experiences or defencelessness that leads to ad hoc partnerships. In the case of branches (meat, dairy, wine etc.) heavily dependent on agriculture, raw materials are best supplied from own production or integration because this reduces risk. There are branches where raw materials must be purchased from abroad (for example cocoa bean and malt), in such cases wholesalers are typical members in the supply chain, but more and more enterprises try to form direct relationships with foreign partners. Consequently they have to deal with language problems. Besides raw materials, other materials (for example packaging materials) are purchased from abroad in order to make the product unique with a unique design or technology.

The technology of Hungarian food production is lagging. The efficiency of second-hand machines, equipment and their age are not necessarily related because those machines that are older than ten years can be as modern as new ones, but this is very dependent on the branch we examine. It is common to buy used machines in Hungary; moreover technologies are often purchased from abroad that are much older than ten years because in Hungary they are still very modern while abroad these machines are no longer up-to-date. Only a few players can afford to buy new machines. When buying machines energy cost reduction is a crucial factor. Frequently the reason for buying new machines is to allow diversification because a new product line often requires new technology and new machines. The Hungarian food industry seems to be very creative: many interviewees said that they have world patents on new production methods and many of them had a unique idea that required unique machines. Innovation is of key importance in the food industry, it is essential to survive. Production methods and new products are the most frequent innovations. Innovation is very hard to describe or quantify, and the amount spent on it is difficult to determine unless staff are employed only for the implementation of the innovation. This is very rare. The most frequent innovation - for the consumers the most noticeable - is product innovation. According to the results of our interviews there are two types of investments, if there were any at all. One group of companies has one larger investment in a couple of years while the other group has one smaller investment every year. 
Almost all participants had experience with tenders. It is extremely hard to measure the utilisation of tenders because there is a strong relationship between the members of the product chain (for example meat processing, manufacture of dairy product, manufacture of wine from grapes). Hence it is very difficult to separate the amount of the subsidy and the effect of the tender. It is also very difficult in the case of innovation to determine what is connected to the food industry and what is linked to agriculture.

When financing investments it is necessary to have an adequate bank connection. When choosing a bank, the most important consideration in the countryside is trust while in big cities the companies evaluate the offers of many banks to exploit the opportunities. Companies with many financial transactions can afford to call for a bank tender. We examined the attitudes of interviewees about bank loans. Micro and small enterprises typically do not want to borrow from a bank either because they have never done it before or they had negative experiences when doing so. Large enterprises had their own ways of financing though they would be better business partners for banks. Many interviewees think that getting a loan is easy because well-operating enterprises regularly get offers from banks. Many of them borrowed from the so called Növekedési Hitelprogram launched in 2013.

The food industry often struggles with employment issues. In many branches the proper educational programmes are missing so there are not enough professionals (bakers, butchers, viticulturists/ winemakers, cheese masters etc.). The other problem is the out-migration of highly qualified professionals from Hungary. Skilled workers (technicians, electricians etc.) are also missing; they often go to work in sectors where wages are higher. Average wages in the food industry are below the average for the national economy. On the other hand, employment is hard to plan because for many products either the raw materials or consumption are seasonal.

There are more and more Private Labels (PLs) and they are increasingly dominant in consumption. Production of PLs is more frequent for large companies because they can use their extra capacities alongside their branded products. Its disadvantage is that PLs provide lower profitability, although frequently they are produced to the same quality and with the same technology as the company's branded products. Retailers push PLs because these products have no brands so consumers do not become loyal to them and the retailer can easily switch the supplier. On the other hand, producers are widely involved in PL production because it facilitates capacity utilisation, it is guaranteed revenue and frequently it is the only way to sell products via a retail chain. We examined the knowledge of producers about trademarks and it confirmed our earlier research results (Darvasné et al., 2014), that consumers do not know trademarks and they are not willing to pay more for products with trademarks.

In production and sales, the knowledge of consumption patterns and circumstances is essential. The interviewees mentioned that consumers' consumption culture causes problems for them because for example in the case of bread, quality is not the most important factor while cheese consumption is limited to the purchase of trappist cheese. On the other hand, consumers are willing to pay more for products often purchased as a gift (wine, confectionary etc.). Consumption is affected by fashion (butter vs. vegetable butter, handicraft products etc.) so it is profitable to start producing these products. Consumers in Hungary are very price sensitive and their purchasing power is rather low. Hence those producers who can produce products with different quality and price levels for different groups of consumers can ensure their position in the market. Large companies can achieve this. Seasonality is present in consumption as well, usually in most of the branches we examined. It is evident that for example in the case of ice cream seasonality is rather strong in summer. Similarly:

- In dairy production yoghurt consumption is very high in January - mainly because of New Year vows;

- In the case of bakeries, meat producers and dairy production, sales decline in summer because of the summer break in schools and canteens; 
- Beer consumption is high in summer;

- Chips and snack consumption are higher at sports events.

The main objective is to sell products with the highest margin and for this purpose many distribution channels can be used. The best solution for micro and small enterprises is the own store or chain of stores, but there are only a few examples of this. For retail chains, refunds cause problems for producers, and often reach 20-30 per cent. Among distribution channels, Hungarian retail chains buy from producers at the lowest price but sell the product with highest margins. Multinational retail chains are hard to negotiate with in the beginning but after the compromise is achieved they are easy to work with. The relationship between distributors and suppliers is more and more tense because of the losses in the trade sector, constantly changing regulations and increasing burdens of participants. Hotels and restaurants have the highest standards; they require outstanding quality. It is difficult for producers to plan production because sales partners often order with tight deadlines and the quantity of their orders varies over time. Handicraft products are typically not distributed in retail because they are not produced in large quantities and they have special production methods (for example chocolate without improvers etc.) which is why they cannot guarantee warrants required. On the other hand, producers with a unique and high-quality product can have a strong bargaining power but only a few can achieve it.

Increasing exports is a potential for the Hungarian food industry but Hungarian products have a low international reputation. Producers have started to recognise that it increases their competitiveness if they try to adjust to the foreign market with the flavour and content of their products. If they try to export the Hungarian version of the product using a trademark this could help in the foreign market. Community marketing could be a good initiative but it is not very sophisticated yet.

Participants in the food chain should think about the whole product line; long-term thinking is essential and they have to cooperate and form the market and power relationships together. The economic, political and legal environment is constantly changing, causing market players to struggle to survive, plan only for the short-term and make decisions without cooperating with other producers. It would be easier for food processors to operate in a constant legal environment. There are too many new regulations, sometimes they are rather inconsistent and there is not enough time allowed to adjust to them. Often, new regulations cause huge financial burdens, especially for smaller enterprises. There are general problems with regulations and there are some specifically disturbing ones such as the handicraft regulation. 'Handicraft product' does not mean that the product is necessarily good and it ruins the significance of the conception. Protection of products is problematic as well, stealing ideas from other producers is common, causing huge losses in competitiveness.

In the Czech Republic the qualitative analysis of the sector was mainly based on secondary data, an on-line survey on innovation activity in food companies and interviews with representatives of research institutes focused on innovation. Market opportunities for the food sector are given by the market environment in the Czech Republic. This environment features not only a wide range of foods and beverages from domestic producers, but also from other EU Member States, especially neighbouring ones, and also so-called third countries, including imports of products originating from outside the temperate zone. The market opportunities are for foods corresponding to current trends. These are:

- Convenience foods, in the context of the changing lifestyles (semi-finished products - such as frozen fruit dumplings, to pour hot water - such as Thai rice noodles),

- Functional foods - with positive effects on the health of the consumer who is willing to pay a higher price (e.g. yoghurts with probiotic cultures, vegetable fats with polyunsaturated fatty acids, products with increased roughage content),

- Organic foods - foods from organic farming (the plan is increase share of market to 3 per cent). Part is of domestic origin and part is from imports (the plan is 60 per cent Czech organic food). 
In the future, income growth should increase the share of high-quality foods, whether of domestic or foreign origin. Market opportunities are also expanding the range of homemade organic foods and health foods, for example containing herbal extracts. Product innovation will lead to greater differentiation of production and the possibility of achieving a competitive advantage for food manufacturers. The European trends will include more differentiation of production in the context of the increasing age of the population and specialisation of production for certain population groups, such as ethnic minorities (the results of interviews with Research and development (R\&D) experts).

Quality schemes are applied in the domestic market - National KLASA (appreciation of about 1,200 products over ten years. Regional foods - competition linked to the region since 2010, with marketing support and EU schemes - Protected Geographical Indication (PGI), Protected Designation of Origin (PDO) and Traditional Specialty Guaranteed (TSG) - with approximately 33 products). Other products from domestic raw materials are guaranteed by the Food Chamber of the Czech Republic (1,500 products from 54 companies). Quality logos are also used as a sales promotion tool. Nevertheless, the use of marketing tools still does not fully correspond with the needs of sales promotion.

On the domestic market, which consists of approximately 10 million consumers and tens of thousands of products, there is fierce competition for suppliers among 9 thousand food companies and other entities doing business under Act No. 513/1991. In doing so, the market shares between the key market players are basically already divided. The EU single market further enhances competition and opportunities for foreign manufacturers. Certain types of goods are purchased directly by consumers in neighbouring countries in the border areas. A significant minority of consumers prefer food from local producers and require that their designation was clear as to where the principal raw material originated and who is the processor.

The smaller part of the market is supplied by short supply chains directly from farms or sold directly at farmer's markets and in farm shops. Owing to the higher quality and usually freshness, these products are sold at a higher price. Although the technology used in the food industry is not usually referred as high, it is essential to maintain high standards of hygiene during the production process and to prevent contamination of raw materials etc. In this respect, the preparatory phase took place in the pre-accession period and later, with significantly positive results both in hygiene and sanitation.

The outdated production lines, packaging machines and other technological equipment are gradually being replaced by more modern versions. New technological units were acquired in all production fields to varying extents, in the context of available financial resources. The new technology is based on the application of the transfer of science and research. New technologies are characterised by continuous processes, integrating the entire sets of individual processes and automation. They are required to be environmentally friendly. Use of the Internet in the reference sector, according to the results of statistical surveys of the CZSO, increases with the size of the company.

The aim of technological change is increasing yield, reducing losses and consumption of energy, water and other materials, as well as increased production, productivity, reducing labour intensity and reducing the cost per unit produced, and in particular increasing the quality of final products. The key problems are concentrated mainly in the non-use of competitive advantages. Therefore, it seems desirable to support innovative processes to achieve greater differentiation and method of processing production. The main barriers of innovation activities in the view of the business community are economic factors - the lack of funds in the company (45 per cent) from other sources (27 per cent) and high innovation costs (32 per cent) and market factors - market dominated by incumbents (33 per cent). The problem remains the transfer of information from research institutions to practice, although cooperation has improved recently. In the period 2008-2010 about one quarter of food 
companies innovated with external partners. In the period 2007-2013, total expenditure on cooperation in the development of new innovations was EUR 16.2 million (EU contribution of 75 per cent, from national sources 25 per cent). Support should be implemented in the 2014-2020 programming period, especially for SMEs with innovations, particularly technological related investment. In 2005, the manufacture of food products invested in acquisition of intangible and tangible fixed assets EUR 394.5 million. But in 2011 only EUR 388.0 million was invested. In the manufacture of beverages, this volume was EUR 153.9 million in 2005 and in 2011 it was a little more (EUR 181.2 million). Investments are, however, cyclical in nature, so we can assume this process will continue, probably increasingly. Financial resources for development will be needed, both their own and foreign, primarily bank loans, which are relatively affordable especially at present, but also support. Public support for technological innovation in the food sector in 2012 was structured as follows:

- Seventh Framework Programme (3.7 per cent of the technically innovative food companies),

- The EU (14.1 per cent),

- The Government of the Czech Republic (9 per cent),

- The regional authorities and the local authorities (0.4 per cent).

Relationships of food companies to suppliers, particularly of agricultural raw materials, are conducted mostly via short-term contracts when there are enough of these materials. In recent years, cost-effective raw material (milk, cattle, cereals etc.) imports helped the food industry when the raw material supply from domestic sources was insufficient, especially in the case of milk where the abandonment of the quota system created pressure in the value chain. It is coming a new generation of packaging. Integrating food companies did not proceed in large numbers, mainly for lack of capital. but there is, both in terms of vertical form, for example within the company Agrofert and from horizontal, for example within the bakery industry. Food producers should strengthen their position as the use of established brands that the consumer prefers and retailers to extend their advantage to private label. The changes occurred in the last 10 years as well as in logistics, and in particular, the construction of modern warehouses near consumption centres (dairies, breweries and other industries).

The illegal economy figures are not only may be mentioned methanol affair on the spirits market, which has the character of crimes in the food industry. Restrictions on the sale of spirits after the onset of this affair in 2012 meant the impact on both the smaller producers of spirits and large manufacturers and distributors. The decrease in the spirits market (by about 10 per cent) is concerned mainly vodka, bitter and herbal spirits and rum. Corrective measures for companies and harsh penalties for the perpetrators of these crimes have already been adopted. As for the gray economy, rarely occurs opinion indicating this economy. The cause is seen in the disintegration of the national economy and good veterinary-hygiene conditions, such as at home slaughter of animals (pigs).

The use of scientific and technical results, development of product, technological and organisational innovations including purposeful acquisitions, seem prospective for the sector, as does the use of support coming both from sale via modern marketing methods and investments from EU funds and national funds (Mezera et al., 2014b). The document "Strategy of Growth - Czech agriculture, support of the national brand, regional production and bio foods" should also contribute to further development of the food industry. The prospect for beverage production are linked both to the growth of domestic consumption and exports, particularly of beed and malt. For this purpose, it is necessary to create conditions in agriculture, preserve areas for growing malt barley and hops. It is also necessary to protect the trademarks and commercial brands.

In Slovakia many changes have happened in the food industry during previous decade, namely production capacities modernisation, new technologies implementation, full adaptation to EU production and hygienic standards, ownership structure. Many branches of food industry are not competitive and they are characterised by low level of specialisation, innovation and co-operation with 
farmers. Production capacities utilization is different by particular food products and food industry dispose with sufficient number of capacities. The result is that imported foods started to displace domestic foodstuff on shop shelves. Since 2003 it started gradual reduction in number of employees in most branches of food industry due to application of rationalisation and effectiveness measures, labour productivity growth, changes in production structure and progressive output decline.

Economic results of food companies that are owned by foreign transnational corporations are affected by production co-operation among their operations located in different countries using price differences of production inputs, advanced processing systems and modern logistics. Economic efficiency of food companies owned by domestic entrepreneurs often lag behind foreign competitors due to outdated facilities and technologies, higher energy demanding and weak motivation to modernization because of small market capacity. In Slovak food industry is generally high wear of tangible and intangible fixed assets and low level of investments. Large food processors prefer purchase of some raw materials abroad due to more advantageous prices, consistency and quality parameters. One of key problem of food industry is virtually non-existent functional and capital linkages with farmers and food retailers.

In the reporting period, the progress of performance manufacture of food products and beverages production divided into three stages. In the first stage, the new conditions after joining the EU, up to 2008 performance in these productions grew. In later years, might be called the second stage, which is associated with the economic crisis and also hit the Czech Republic, the performance of these productions declined. In the third phase, from 2011, in the manufacture of beverages, from 2012 there was a revival again. Diversified and fluctuating development occurred as the individual disciplines and companies.

Labour productivity increased in the manufacture of food products in the time period of membership in the EU. Labour productivity growth has caused a reduction in the number of employees. Revenues grew with the exception of the years 2007 and 2008, when declined due to the economic crisis. The average value of the indicator of the profitability of revenues during the reporting period was 2.2 per cent. This indicator is influenced by the level of competition in the industry, cost and also price policy of the commercial chains. Labour productivity in the manufacture of beverages (value added per employee) increased more than in the production of food products. Revenues in this production began to rise in 2012 after three years of decline (2009-2011). Profitability of revenues decreased significantly from 10 per cent in 2005 to 5.5 per cent in 2012 due to the increasing costs of production. The largest growth in labour productivity for the period under review was achieved in the production of prepared feeds due to the high growth of sales of own products and services and the declining number of employees.

The highest increase profitability of revenues for the period 2005-2013 should manufacture of other food products (increase of 3.1 per cent). Production of the greatest value of this indicator was the production of beverages ( 5.4 per cent) in 2013. The lowest value of this indicator should Processing and preserving of meat and production of meat products ( 0.6 per cent) in the same year. In the manufacture of food and beverages had recorded the largest decline in profitability of the revenues for category of small enterprises (10-19 employees). According to the development of the share of sales of own products and services for various branches of the revenues of the entire production of food products had the largest increase (5.9 percentage point) during the reporting period Manufacture of prepared feeds (CZ-NACE 10.9). This indicator decreased the most from all branches (by 3.3 percentage point) in the production of vegetable and animal oils and fats (CZ-NACE 10.4). The food branch with the largest growth in the volume of sales of own products and for the period 2005-2013, had the production of prepared feeds (CZ-NACE 10.9). This branch should, according to preliminary results the largest revenue growth in 2013 (20.2 per cent). 
The indicator CR increased in most fields. This indicator in 2013 reached values by branches from 21.0 per cent to 86.7 per cent. The range of control of the food market from the largest companies increased. FDI resumed in 2012, when it reaches the maximum value from the entry into the EU. It shows to restoring of investors' confidence in the food industry. Entry fourth largest brewery on the Prague Stock Exchange shows the possibilities of obtaining financial resources for further development through public issue of shares. According the SWOT analysis for food fields within the document to the Ministry of Agriculture strategy - in the Czech food industry is expected mainly to the strong growth of the efficiency and competitiveness of this industry in the EU single market and the world market.

In 2012, 3.6 per cent of the total number of food businesses carried out the research and development. Expenditures for the research and development in food and beverage production of Slovakia has an increasing tendency. In 2004-2012 they raised from EUR 438 thousand up to EUR 1.2 million. Despite of it, the share of expenditure on research and development in the Slovak Republic is less than one percent. Of the total amount of food enterprises, 38.3 per cent food and beverage companies produced certified products (Certified products are the products with valid certificate issued either by an accreditation place on the basis of the Act on State Testing Lines or by a foreign organization. A certificate verifies that the properties of a certified product are in conformity with the relevant standards, technical documents or laws; definition of the SO SR). Most companies with certified products come from the meat and poultry field with 17 per cent and 13 per cent of dairy field, 11 per cent of bakery field and 7 per cent of canning field. In 2012, there were 7.3 per cent of the Slovak food companies with licences concluded with foreign organization for the purchase or sale of licences whose term of validity has not expired. Innovation expenditures amounted to EUR 62,031 in the food industry in 2012. This represents 4.5 per cent of the innovation expenditures of the Slovak economy and 5.8 per cent of the innovation expenditures of the industrial production. Revenues in companies with innovations in the Slovak Food industry were EUR 2.4 billion in 2012. Share of revenues in food companies with innovations of the Slovak economy was 3 per cent in 2012 and it has had falling trend since 2008 .

Number of innovative enterprises has falling tendency in 2006-2012. Enterprises without innovation activities dominate in the sector. Within innovative enterprises, enterprises with innovations in technology and product and/or process innovative enterprises prevail over enterprises: with product innovations, with process innovations and product and process innovative enterprises. In terms of the situation in innovations within the Slovak Food Industry it is not negligible (though not significant) number of enterprises with only non-technological innovations.

Investment state in the Slovak Food Industry was fluctuating during the years; since 2010 the investments are falling continuously with variable falling dynamics. The investments in the sector fell from EUR 234 million in 2003 to EUR 157 million in 2012. The amount of foreign capital in the food industry of Slovakia also had a falling tendency in 2003-2012. In 2012, costs for retail chain supplement ${ }^{7}$ were 4.2 per cent from the total costs of the industry, the costs oscillated around 4 per cent in the most recent years (the indicator was noticed since 2009 and in the period 2009-2012 reached maximum 4.3 per cent). Costs for retail chain supplement in food industry varied according to production sectors in 2012 as follows: canning 26.5 per cent, malting and brewing 22.6 per cent, dairy 13.3 per cent, meat 9.6 per cent, confectionery 6.4 per cent, wine 4.5 per cent, bakery 4.1 per cent, non-alcoholic beverages 3.4 per cent, starch 2.9 per cent and other sectors below 3.5 per cent (whereas poultry 2.1 per cent, fat 1.5 per cent, milling sector 0.8 per cent). Share of costs for retail chain supplement was differentiated among the sectors in the years 2009-2012. The highest propor-

\footnotetext{
Costs for retail chain supplement are costs connected with a sale of the product into a retail chain under the conditions in the contracts signed with costumers (for example, costs of the contractor while entering contractors' chain, costs connected with product registration and packing the goods to the shelf, costs of advertising leaflets, which are pre-financed by suppliers), as well as costs connected with discount prices. This indicator comes from the report of MPVR SR.
} 
tion in costs for retail chain supplement has traditionally canning companies and malting-brewing sector, both with rising ratio, and dairy, meat, confectionery sector with declining ratio.

Indicator "Share of the Slovak food products in the food retail market" was created to estimate measuring of the competitiveness of the Slovak food producers in the domestic market. Indicator is calculated from the databases of the SO SR and MPRV SR that are not identical, therefore the is not exact. Nevertheless, we might say the share of the Slovak food products in the Slovak food retail market is in a decline in a longer term; while in 2003 the share was 78.9 per cent, in 2012 it fell to 38.9 per cent.

There exist two systems connected with food quality in Slovakia (MPRV SR, 2014): the 'SK Mark of Quality' and 'EU Quality Policy'. Within the production and consumption of domestic food production, one of the basic aspects is the 'SK Quality Label' National Programme of Promotion of Agricultural Products and Foodstuffs, which was created to provide the consumer with sufficient information on safe and quality domestic products. The goal of this programme is to draw the attention of Slovak consumers to quality domestic foodstuffs. Any Slovak producer can be awarded the SK Quality Label if its products are made of domestic raw materials and if the producer complies with declared technological procedure, quality parameters and the safety of foodstuffs as stipulated by the relevant legal regulations governing food law. In order to hold the SK Quality Label, at least 75 per cent of raw materials must be made in Slovakia, while all the phases of the production process must take place in the country. A GOLD Quality Label is awarded to products with the abovestandard qualitative parameters, which distinguish them from other general foodstuffs and emphasise their higher quality.

'EU Quality Policy' is a philosophy of the development of the quality of original, traditional agricultural products and foodstuffs, and the promotion of cultural traditions and regions where these products are produced. The system has been developed in response to the increasing counterfeiting of products and the misuse of traditional names that guaranteed the reputation of traditional, regional products. The 'EU Quality Policy' means the protection of agricultural products and foodstuffs and their promotion. These foodstuffs must meet certain qualitative parameters that distinguish them from other similar products, this based on their precisely defined requirements for raw materials and the technological procedure of the production. Within the EU Quality Policy, the EU accepts, protects, supports, registers and inspects the products broken down into three categories as follows:

- Protected geographical indication - PGI

- Protected designation of origin - PDO

- Traditional speciality guaranteed - TSG

Within the EU Quality Policy system, the following Slovak products and foodstuffs were registered as of 11 February 2014: Skalický trdelník, Slovenská bryndza, Slovenská parenica, Slovenský oštiepok, Tekovský salámový syr, Zázrivský korbáčik, Oravský korbáčik - PGI; Bratislavský rožok/Pressburger Kipfel/Pozsonyi kifli, Ovčí hrudkový syr-salašnícky, Ovčí salašnícky údený syr, Lovecký salám/Lovecká saláma, Liptovská saláma/Liptovský salám, Špekáčky/Špekačky, Spišské párky - TSG and Žitavská paprika - PDO. As to the PGI, the EC has received applications for the following products: Klenovecký syrec and Zázrivské vojky in 2012 and Levický slad in 2013.

\section{Conclusions}

In this chapter the general economic and financial situation of the food industries of the Czech Republic, Slovakia and Hungary was analysed, including the position in the national economy, their output, revenues, employment and their main financial results. We also examined the main branches of the food industry including their state and contribution to the food industry. Besides statistical analysis, qualitative information was used in order to see behind the data and to find out the contrib- 
uting background factors of the values of the food industries' main parameters. Despite methodological differences, the main characteristics and development possibilities in the Czech Republic, Slovakia and Hungary are very similar. So they face the same problems, they undergo the same trends and they have similar weaknesses to work on.

Data from 2003-2013 clearly showed that the economic and financial crisis of 2007-2008 shocked the food industries in all three countries. The number of employees decreased in absolute values and as a share of national employment in all countries throughout the examined period, and after 2008 it started to fall more quickly. Revenues of the food industry increased until 2008 in all three countries but after the crisis they started to decline. By 2011 the decline halted and revenues started to increase. By 2012 revenue in Hungary exceeded the 2008 level.

During the past ten years the food industries of the three countries went through technological development, improvement of production methods and better utilisation of capacities. The cause on one hand is that the countries joined the EU in 2004 and from that time they had to meet certain hygienic, production and quality control requirements. On the other hand, the competition became sharper than before so food industry participants recognised the importance of development in order to be able to stay in the market. Despite the fact that the lag of domestic producers is still huge, mainly large enterprises can afford to invest and develop. In many cases the cause for the investment capability of large companies can be the high share of foreign capital in their nominal capital. Companies in foreign ownership can afford investments for development and innovation and for better financial results.

The situation of domestic producers is worsened not only the fact that they do not have the technology that large companies with foreign backgrounds have, but also because cheaper imported products and private labels started to flood store shelves. Besides the supply side there are problems on the demand side as well because the purchasing power of consumers is rather low, which is why they prefer cheaper solutions. Other common problems are that food industry participants do not cooperate and communicate with each other, they lack the strategic thinking for the longer term and they do not consider the whole food chain. Participants in the food chain have to think about the whole product line, long-term thinking is essential and they have to cooperate and form the market and power relations together to survive. 


\title{
Employment in agriculture
}

\author{
HAMZA, Eszter ${ }^{1}$, BUCHTA, Stanislav² and DRLÍK, Jan ${ }^{3}$
}

\section{Introduction}

In Slovakia, the Czech Republic and Hungary, agriculture has an important role in the national economy and the contribution of agricultural employment to improving the income positions of the rural population is indisputable. However, the high levels of economic inactivity and long-term unemployment in the three countries, especially in the rural areas, the aging population and the increasing proportion of people who continuously need the social care system are persistent problems.

This chapter presents a comparative analysis of the role of agriculture in employment, identifying the factors which have an impact on employment and exploring the potential of job creation in agriculture. It starts with an assessment of the situation in the period before the accession to the EU of the three countries and on this basis evaluates the changes that have led to the present situation of agricultural employment. The study includes a comparative analysis of the legal and support policy aspects of the dominant employment forms in the agricultural sector. Research cooperation offers the opportunity to develop policy instruments which are favourable in agricultural employment and to increase the efficiency of the interventions which are already in place.

\section{Labour market activity}

Agricultural employment is influenced by the general long term labour market trends. The employment rate increased in all three countries between 2004 and 2008, while the unemployment rate decreased by almost half in Slovakia and the Czech Republic, and it remained unchanged in Hungary. In the period 2008-2010, owing to the negative impact of the economic crisis on the labour market, employment decreased and unemployment increased significantly in all three countries. However, more favourable labour market trends were characteristic between 2010 and 2014: employment continuously expanded in all three countries, while unemployment has been declining (Figure 1). As a result of the improving labour market indicators, the unemployment rate of the population aged 15-64 was lower than the EU-27 average in Hungary (by 2.5 percentage points) and in the Czech Republic (by 4.1 percentage points).

Among the three countries the Czech Republic has the most favourable labour-market activity indicators (activity rate, employment and unemployment rate). The employment rate reached 69.0 per cent in 2014, which is 7.2 percentage points higher than the Hungarian and 8.0 percentage points higher than the Slovakian value. The unemployment rate is the highest in Slovakia, however the rate decreased from 18.1 per cent in 2004 to 13.2 per cent in 2014. The number of unemployed people dropped from 480.7 thousand persons in 2004 to 358.7 thousand persons in 2014 . The overall unemployment rate in Slovakia is still high in comparison with neighbouring countries and the average of the EU.

The available income from other sectors has a significant impact on agricultural employment and the labour supply. In Hungary, farm income was only 2.4 per cent of the whole income generated in the national economy in 2014. In the last 20-25 years, positions of income for the agricultural population have remained basically unchanged. Agricultural incomes lagged behind the national economy as a whole by around 23-30 per cent between 2004 and 2014. The low productivity of agricultural activities, the unskilled agricultural labour force and the low profitability level of the sector played a significant role in the unchanged income disparities (Kapronczai, 2010).

\footnotetext{
Research Institute of Agricultural Economics, Budapest, Hungary.

National Agricultural and Food Centre - Research Institute of Agricultural and Food Economics, Bratislava, Slovak Republic.

Institute of Agricultural Economics and Information, Prague, Czech Republic.
} 
Figure 1: Employment and unemployment rate in the Czech Republic, Hungary and Slovakia, 2004-2014.

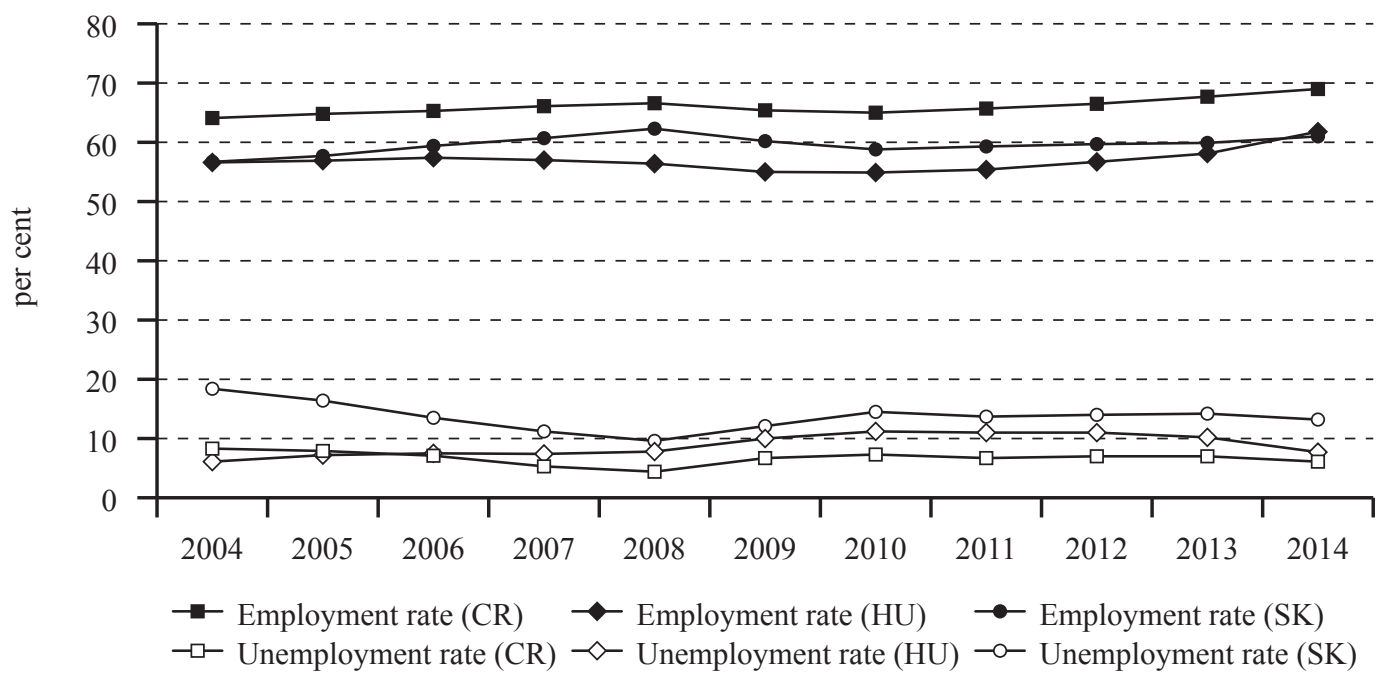

Source: Eurostat

As in Hungary, wages in Czech agriculture are as a long-term average lower than in industry and in the total national economy, and the rate of disparity fluctuates around 80 per cent. The significant wage between agriculture and both industry and the national economy is well-known and represents a barrier for graduates of agricultural schools to enter the agricultural sector. In Slovakia, the average wage in agriculture reached only 76 per cent of that of the national economy. Over the long term, the relationship has fluctuated around 75 per cent of the average wage in the national economy.

\section{Employment situation in the agricultural sector}

Agricultural employment and the agricultural labour force is examined using several statistics. The most commonly used sources of statistical data on labour use in EU agriculture are the National Accounts (NA), the Labour Force Survey (LFS) and the Farm Structure Survey (FSS). The LFS covers the whole economy and allows comparisons between different economic sectors. In contrast to the LFS, the EAA, which are part of the national accounts, take account of the characteristics of the sector, namely that the share of part-time and seasonal employment in agriculture is significant. However, these statistics are only provided for agriculture. Family labour force of agricultural holdings in the context of the FSS refers to persons who carry out farm work on the holding and are classified either as a holder or the members of the sole holder's family.

\section{Agricultural employment}

Since the political and economic transition, the labour force in agriculture has dramatically declined in the three countries. Between 1989 and 2014 the number of people working in agriculture declined to one-fifth in the Czech Republic, to nearly one-seventh in Slovakia and to about a quarter in Hungary. The pace of agricultural labour outflow has slowed in recent years due to the economic crisis but it is still continuing, while the role of the service sector in employment is growing. This is a general trend in times of economic growth: when unemployment is low, higher incomes are attainable and the more favourable working conditions in other sectors of the national economy speed up the outflow of labour from agriculture, generating technological development in the sector and thus the process of mechanisation becomes faster. This has been the prevailing trend in most EU Member 
States, resulting in the shrinking role of agriculture in the national economy and its declining share in total employment. In times of economic slowdown or recession, the fewer urban job opportunities and the moderate expansion or the contraction of the industrial sector reduce the flow of labour from agriculture and thus the demand for technological investment (Chavas, 2001; Davidova et al., 2013). The share of agriculture in employment was the highest in Hungary (4.2 per cent), while in the Czech Republic it was 2.6 per cent and it was 3.5 per cent in Slovakia in 2014. The development of employment by sector shows the effects of the economic crises in the late 2000s, when the decrease of agriculture's share in employment came to a halt (Figure 2). Meanwhile the share of employment of the tertiary (services) sector has been continuously rising since 2004 in all three counties.

Figure 2: Share of employment in agriculture in the Czech Republic, Hungary and Slovakia, 2004-2014.

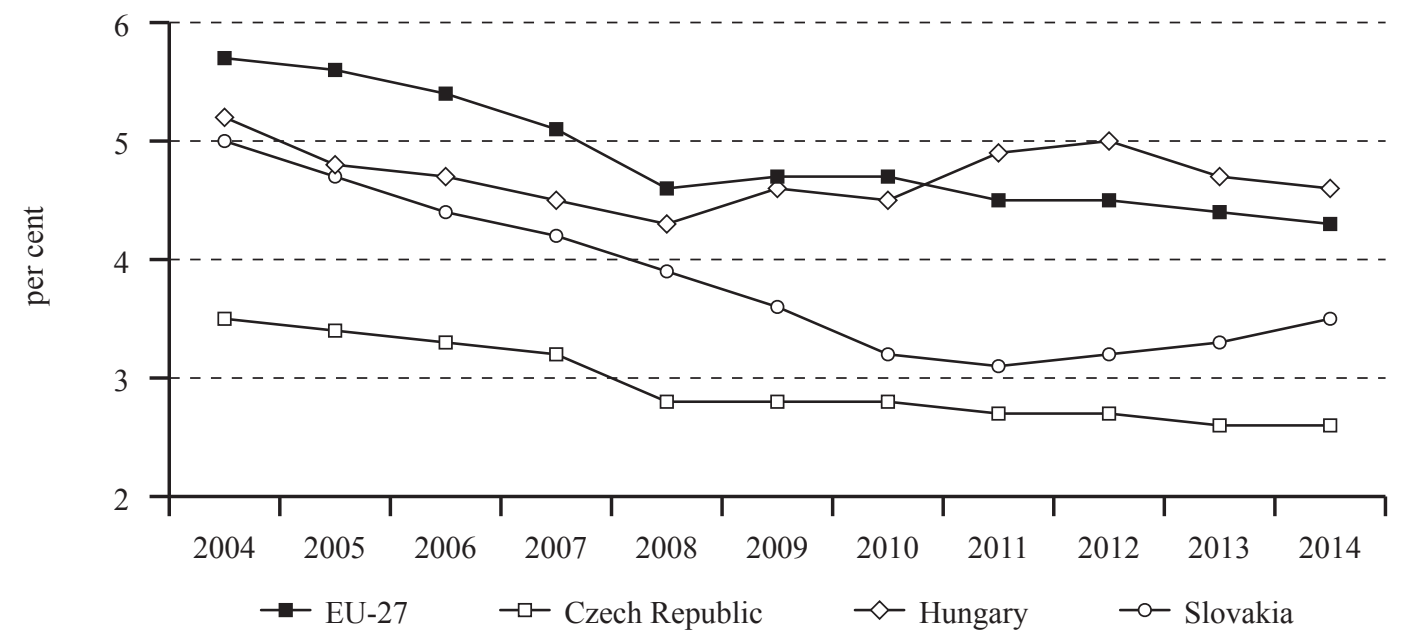

Source: Eurostat

In the Czech Republic, according to the LFS, 240 thousand people worked in agriculture in 2000 but by 2011 their number had decreased to 142 thousand, before recovering slightly in 2012 . In Hungary, after the strong decline in the 1990s the share of agriculture in employment decreased from 6.3 per cent to 4.5 per cent, i.e. at a slower pace, between 2000 and 2014. The declining trend was broken in 2011. The number of employees in the sector increased by 16.8 thousand between 2010 and 2014. In 2014, 189 thousand employees (4.6 per cent of total employment) worked in the agricultural sector. The employment growth mostly occurred in small-scale farmers' organizations, seasonal or part-time jobs, and it was helped by new legislation concerning these atypical forms of employment (Biró and Rácz, 2014).

In Slovakia the long-time continuous decrease in the number of farm workers in agriculture seemed to stop in 2014. The number of farm workers amounted to 51.5 thousand people, which represented a 1.8 per cent increase between 2014 and 2015. Job creation measures under the Rural Development Programme 2007-2013 affected job creation in agriculture positively. After a long time, the number of newly created jobs in agriculture was higher than the number of jobs lost in 2014. This increase in agricultural employment is shown by an annual increase of 5.8 per cent in organisations with 20 and more employees. 


\section{Agricultural labour input}

Agricultural labour input is measured in AWU, which are defined as full-time equivalent employment (corresponding to the number of full-time equivalent jobs) and represent the total number of days worked in a year by the salaried and unsalaried within the agricultural industry. Agricultural labour force input is the highest in Hungary. It shows as if 463 thousand people had performed agricultural activities all year long full time. Labour input follows a declining trend in the long term due to the continuous decrease in the number of holdings (including households engaged in production). Agricultural labour input has decreased by 14.4 per cent since 2004 . The decline of the agricultural labour force was the highest (48.1 per cent) in Slovakia, while in the Czech Republic it was 27.7 per cent between 2004 and 2014 (Table 1).

Table 1: Total labour force input in the agricultural sector in the Czech Republic, Hungary and Slovakia, 2004-2014.

\begin{tabular}{lrrc}
\multicolumn{1}{c}{ Country } & $\mathbf{2 0 0 4}$ & $\mathbf{2 0 1 4}$ & $\begin{array}{c}\text { thousand AWU } \\
\text { Growth rate } \\
(\mathbf{1 0 0 \%}=\mathbf{2 0 0 4})\end{array}$ \\
\hline Czech Republic & 144.9 & 105.1 & -27.7 \\
\hline Hungary & 553.8 & 462.9 & -14.4 \\
\hline Slovakia & 105.4 & 53.9 & -48.1 \\
EU-27 & $12,542.9$ & $9,573.7$ & -25.1 \\
\hline
\end{tabular}

Source: Eurostat

According to the EAA, there are substantial differences among the three countries in the shares of salaried and non-salaried labour in agricultural labour force. In the Czech Republic and Slovakia, the share of salaried labour was over 70 per cent, while in Hungary it was only 27.2 per cent in 2013. While in the Czech Republic the share of salaried labour decreased 8.5 percentage points between 2004 and 2014, it increased in Hungary (5.3 percentage points) and Slovakia (4.1 percentage points points) (Table 2).

Table 2: Share of salaried and non-salaried labour force in the agricultural sector in the Czech Republic, Hungary and Slovakia in 2004 and 2014.

per cent

\begin{tabular}{lcccc}
\hline \multirow{2}{*}{ Country } & \multicolumn{2}{c}{$\mathbf{2 0 0 4}$} & \multicolumn{2}{c}{$\mathbf{2 0 1 4}$} \\
\cline { 2 - 5 } & salaried & non-salaried & salaried & non-salaried \\
\cline { 2 - 5 } & \multicolumn{4}{c}{ labour force } \\
\hline Czech Republic & 83.2 & 16.8 & 73.5 & 26.5 \\
\hline Hungary & 23.0 & 77.0 & 27.0 & 73.0 \\
\hline Slovakia & 63.5 & 36.5 & 67.6 & 32.4 \\
\hline EU-27 & 21.0 & 79.0 & 25.5 & 74.5 \\
\hline
\end{tabular}

Source: Eurostat

Agricultural labour productivity - expressed in GVA/AWU - is the highest in the Czech Republic, 12,600 EUR/AWU, which is double the Hungarian value (EUR 6,409/AWU). In Slovakia labour productivity in agriculture was EUR 9,761/AWU in 2013. The number of AWU per 100 ha of UAA is about 3 in the Czech Republic, similar to Slovakia (2.8 AWU/100 ha) in 2013. This average is much higher in Hungary (9.3 AWU/100ha) due to the large number of small farms. Labour productivity is closely related to the characteristics of the farm and production structure. While the average farm size 
is relatively high (133.0 hectares) in the Czech Republic and in Slovakia (80.7 hectares) in 2013, the Hungarian agriculture was still characterised by a high share of small farms and family labour, and The average farm size was only 9.5 hectares.

\section{The typical forms of employment in agriculture}

In Hungary, as in most EU Member States, agriculture is characterised by family farms, and the family labour force represented 78.6 per cent of the total regular labour force in agriculture in 2013 , compared to 26.9 per cent in the Czech Republic and 28.5 per cent in Slovakia. These latter values can be attributed in part to the nearly 70 per cent of the total farm labour force in agriculture working in corporate farms.

Employees in holdings of legal persons (i.e. agricultural cooperatives, joint stock companies and limited liability companies) are predominant among workers in Czech agriculture, most of them as permanent staff. There are some seasonal workers, but - mainly due to the low share of the F\&V in total agricultural production - their numbers are not too high. Irregularly employed non-family members reached only 3.1 per cent of the total AWU in the Czech Republic (2013) which is just half of the EU average. Part-time employment in Czech agriculture (4.4 per cent in 2012) is only one fifth of the EU average. Other important group represents people working in holdings of natural persons - holders, their family members and employees. Not all the holdings of natural persons in Czech Republic are "genuine" family farms - some farms are too small (mainly holdings of pensioners - often "hobby farms") or too large (with predominantly salaried labour - as in holdings of legal persons).

In Hungary most of the agricultural labour is based on family labour (78.5 per cent of the regular labour force in agriculture). This labour input is seasonal and additional work carried out outside of agriculture is often required for subsistence (Biró and Székely et al., 2012). Based on FSS data, 983 thousand family members belonging to holdings performed agricultural work to various degrees in private holdings in 2013. This corresponds to 315.8 thousand workers Full Time Equivalent (FTE). The family labour input of private holdings decreased by nearly 28 per cent compared to the survey in 2003, mainly as a result of a 37 per cent drop in the number of farms. While family labour has decreased in recent years, the numbers of both temporary and permanent employees has increased in Hungary. The number of permanent employees (12.0 thousand people) of private farms in 2013 was 31.2 per cent higher than the level of the previous three years. The majority of the increase was accounted for employees who worked at least 225 days. The number of temporary employees has increased more significantly: their number was 85.5 thousand in 2013 , which is 53.0 per cent higher than in 2010. Corporate farms employ salaried work force only due to the characteristics of the legal form. These organisations employed 85.3 thousand permanent employees in 2013, which is 7.6 per cent higher than three years earlier. The size of the temporary labour force in corporate farms increased dramatically - more than one and a half times - during this period (42.7 thousand people, 153.3 per cent).

Act No. 75/2010 introduced substantial simplifications and concessions for temporary employment within seasonal agricultural work. Owing to the legislative changes intended to moderate public and administrative burdens, the number of seasonal employees showed a spectacular increase after 2010. The number of seasonal agricultural workers amounted to a quarter of the total agricultural workers and grew by 27.1 per cent between 2010 in 2013.

In Slovakia, employees (87 per cent) predominate in the agricultural workforce. The current structure of the agrarian workforce is characterised by a high share of employees with poorly perceived co-owner's motivation. Between 2004 and 2014 there was an increasing number of employees of private limited companies and fewer employees within farm cooperatives. Between 2000 and 2010 employment fell by half, while the number of persons working part-time increased threefold. The 
increasing number of part-time jobs was typical for all legal forms in agriculture. The seasonal workforce increased from year to year in agriculture. However, this trend continued until 2012. Since 2013 the short-term employment by working contracts has been substantially reduced. The reason for this decline (annual decline was 6,528 contracts, i.e. nearly one-third) was the fact that social security started to be paid and the price of seasonal work has substantially increased for employers. Large employers started to solve seasonal working through the temporary work agencies. Employees of the agencies replaced the individual workers and bartered jobs. This is confirmed by the fact that payments to part-time workers have increased by 28 per cent from 2011 to 2013.

\section{The features of agricultural labour}

\section{Age structure}

One of the most important demographic trends that influences the restructuring of agriculture is the reduction in the agricultural workforce of active age as a result of lifestyle changes, out-migration and ageing (Chavas, 2001). Demographic renewal is hindered by low wages, the low prestige of agricultural jobs in accordance with the low standard of living and the problematic access to basic services in many rural areas (Székely, 2009). The ageing of agricultural employees and farmers is typical in all the three countries. The age structure of agricultural employees is much worse than the average of national economy in Hungary and the Czech Republic. In the Czech Republic, agriculture - when compared to the average of national economy - has a lower share in the younger age categories (under 24 years, 25-29, and 30-44 years old) on the one hand and a higher share in the older age categories (45-59 years and over 60 years old) on the other hand. While the population in the whole national economy reflects only the general ageing of the population, the agricultural population is becoming older faster.

In Hungary, the share of the agricultural employees in the younger age categories (15-29 and 30-39 years old) is 5-6 percentage point lower than that of the employees in national economy. The share is almost the same in the 40-49 years old age category, but in the older (50-60 years old) age group the rate share agricultural employees is 7 percentage points higher than in the national economy. In Slovakia, most agricultural employees belong to the age categories 50-59 years (38.4 per cent) and 40-49 years (30.8 per cent). The average age in agriculture in 2014 reached 46.6 years (c.f. 41 years in the national economy).

Comparing the data of the three countries according to FSS categories, Slovak farm managers had the most favourable age structure (8.1 per cent of farm managers were under the age of 35 in 2013) (Table 3). While the share of farm managers under 35 years decreased between 2005 and 2013 in Hungary and the Czech Republic, it almost doubled in Slovakia.

In Hungary the age structure of farm holders is more unfavourable than of agricultural employees. The average age of farmers was 56 years in 2013. According to the trend, rejuvenation can be observed in Slovakia, while farm managers are characterised by ageing in Hungary and in the Czech Republic. 
Table 3: Age structure of the farm managers in the Czech Republic, Hungary and Slovakia in 2005 and 2013.

\begin{tabular}{lccccc}
\hline Country/Age group & $<\mathbf{3 5}$ & $\mathbf{3 5 - 4 4}$ & $\mathbf{4 5 - 5 4}$ & $\mathbf{5 5 - 6 4}$ & $\mathbf{6 5}<$ \\
\hline Czech Republic & 9.9 & $\mathbf{2 0 0 5}$ & \\
\hline Hungary & 7.8 & 14.3 & 28.6 & 27.5 & 16.7 \\
\hline Slovakia & 4.4 & 14.0 & 26.0 & 24.2 & 27.2 \\
\hline \multicolumn{7}{c}{$\mathbf{2 0 1 3}$} \\
\hline Czech Republic & 4.6 & 14.8 & 25.8 & 28.8 \\
\hline Hungary & 6.1 & 14.9 & 19.4 & 23.8 & 23.0 \\
\hline Slovakia & 8.1 & 15.4 & 24.9 & 30.0 & 21.6 \\
\hline & \multicolumn{7}{c}{ Change (100\%=2005) } \\
\hline Czech Republic & 46.0 & 85.4 & 83.1 & 130.3 \\
\hline Hungary & 79.1 & 100.5 & 74.9 & 123.2 & 111.3 \\
\hline Slovakia & 185.0 & 110.5 & 91.6 & 116.3 & 75.2 \\
\hline
\end{tabular}

Source: Eurostat, FSS

\section{Gender}

In the EU-27, 64.9 per cent of the total labour force in agriculture was male in 2013. The ratio of males to females working in agriculture was almost stable in the Czech Republic and Slovakia during the period 2005-2013, while it increased by 35.0 per cent - i.e. the proportion of males in total regular farm labour force grew - in Slovakia (Table 4). The proportion of female labour in the total regular farm labour force much lower in Slovakia (27.4 per cent) and the Czech Republic (30.1 per cent) than in Hungary (37.3 per cent).

Table 4: Males per female ratio as regular farm labour force in the Czech Republic, Hungary and Slovakia in 2005 and 2013.

\begin{tabular}{lccc}
\hline \multicolumn{1}{c}{ Country } & $\mathbf{2 0 0 5}$ & $\mathbf{2 0 1 3}$ & $\begin{array}{c}\text { Change } \\
(\mathbf{1 0 0 \% = 2 0 0 5 )}\end{array}$ \\
\hline Czech Republic & 2.1 & 2.3 & 109.2 \\
Hungary & 1.6 & 1.6 & 100.0 \\
\hline Slovakia & 2.0 & 2.7 & 135.0 \\
\hline EU-27 & 1.7 & 1.8 & 106.1 \\
\hline
\end{tabular}

Source: Eurostat, FSS

\section{Education and qualification level}

The presence and availability of qualified human capital is a basic condition for increasing agricultural productivity (Swinnen and Knops, 2013). Higher levels of qualifications and practical experience increase the adaptability of farms, promote specialisation and the application of innovative solutions, technologies and methods of productions (Baptista, 2012). Agriculture has become a knowledge-intensive sector. The management of challenges caused by the changes of economic, social and natural environment requires, besides traditional, farm-specific knowledge, the acquisition of new skills and competencies (Dudek et al., 2014). 
Although the general trend shows that the agricultural sector is lagging behind in the level of education compared to other sectors of the national economy in all the three countries, as in other sectors an improving trend can be observed.

In the Czech Republic, the general level of education of agricultural workers is the same as in industry. Small differences persist and the situation in agriculture is slightly worse, mainly because of the higher share of people with only elementary education in agriculture on the one hand and the lower share of people with secondary education with A-level qualifications on the other hand. At the same time, it means that contemporary agriculture in the Czech Republic does not provide many job opportunities to people with lower levels of education.

In Hungary the share of agricultural employees with tertiary education degrees is approximately 10 per cent while the figure in the national economy is 25 per cent according to the census in 2011. Almost two-thirds (62.5 per cent) of agricultural employees have completed secondary education, similar to the share of those employed in the national economy. The proportion of employees with only elementary education is 27 per cent in agriculture, which is double the figure in the national economy (11 per cent).

In Slovakia, 8 per cent of agricultural employees had only primary education in 2014 . On the contrary, the share of graduated employees in agriculture was 9.6 per cent in 2014. Furthermore, in 2014 every tenth worker in agriculture was a graduate. Considering increasing demands on the quality of human capital and sector modernisation, this share is still rising. The number and quality of qualified experts are able to ensure conditions for the sector, where business competitiveness have become the limiting development factor.

As regards the agricultural qualification levels of farm managers, the FSS data provide comparable information for the three countries. The proportion of qualified farm managers is the highest in the Czech Republic, where half of the farm managers have taken part in basic or full agricultural training (Table 5). However, in Hungary and in Slovakia the majority (82.1 per cent in Hungary, 75.7 per cent in Slovakia) of holders of private holdings managed their holdings on the basis of practical experience only. The level of professional qualifications of farm managers is the lowest in Hungary, which can be explained primarily by the high number of small farms that are managed on the basis of practical experience only.

Although the qualifications of agricultural workers are improving, in the agrarian sector qualification potential is lower than in other sectors, and this limits the possibility of increasing the technological level of production and the use of innovation. Weak innovation potential leads to lower quality production and shows the demand for labour with lower levels of human capital, the so-called low-skill and bad-job trap ${ }^{4}$ (Snower, 1994). In the human resources two important groups of workers are important, namely qualified and business-oriented management and skilled workers with the corresponding practice.

\footnotetext{
Bad jobs are associated with low wages and limit opportunities for accumulation of human capital.
} 
Table 5: Agricultural training level of the farm managers in the Czech Republic, Hungary and Slovakia in 2005 and 2013.

per cent

\begin{tabular}{|c|c|c|c|}
\hline Country / training level & $\begin{array}{c}\text { Practical experience } \\
\text { only }\end{array}$ & Basic training & $\begin{array}{c}\text { Full agricultural } \\
\text { training }\end{array}$ \\
\hline \multicolumn{4}{|c|}{2005} \\
\hline Czech Republic & 55.3 & 19.6 & 25.2 \\
\hline Hungary & 86.6 & 4.9 & 8.5 \\
\hline Slovakia & 85.4 & 11.2 & 3.4 \\
\hline \multicolumn{4}{|c|}{2013} \\
\hline Czech Republic & 46.7 & 18.7 & 34.6 \\
\hline Hungary & 82.1 & 14.4 & 3.5 \\
\hline Slovakia & 75.7 & 15.1 & 9.2 \\
\hline \multicolumn{4}{|c|}{ Change $(100 \%=2005)$} \\
\hline Czech Republic & 84.4 & 95.7 & 137.6 \\
\hline Hungary & 94.8 & 294.1 & 40.8 \\
\hline Slovakia & 88.6 & 134.0 & 275.4 \\
\hline
\end{tabular}

Source: Eurostat

\section{Agrarian unemployment}

In the Czech Republic the IAEI monitors agrarian unemployment using its own methodical tool "signal rate of agrarian unemployment". This is based on the number of unemployed people released from class "A" of CZ-NACE. Just after 1989, people (often young, educated and with non-agricultural professions) could quite easily find new non-farm jobs. After 1996 the signal rate of agrarian unemployment started to increase and reached its contemporary peaks in 1999 and 2004. After 2005 a decrease could be observed - but it still remained (over a long-term comparison) above the level of national economy as a whole. Seasonal volatility is a specific feature for agriculture. Another phenomenon is the permanently higher unemployment of women compared to men (however, this is possible to observe in the national economy as a whole too). On average, when omitting seasonal volatility there is no significant difference between unemployment in agriculture and in the national economy. For instance, in the second quarter of 2014 the level of agrarian unemployment reached 5.8 per cent, while in the national economy it was 4.8 per cent. Anyway agrarian unemployment is not negligible, but it is not a crucial problem of Czech agriculture (for instance the low influx of young and qualified people represents a more serious long-term problem).

In Hungary, the number of unemployed in the agricultural sector reached its peak in 2010 as it did in the national economy as a whole, and thereafter it decreased significantly. In 20154.4 per cent of job seekers (10.1 thousand people) worked in agriculture previously. The share of women within agricultural unemployment is overrepresented compared to their share in employment: while 24 per cent of the employed are female workers, their share among the unemployed is 30.5 per cent. Employers usually lay off middle-aged and older workers who are less likely to find new jobs and whose retraining is more difficult than for younger people. Job seekers' connection to agriculture is the strongest in rural areas. The number of vacancies connected to agriculture are also the highest in rural areas. The number of agrarian unemployed is higher than vacancies in agriculture, so agricultural labour markets are characterised by a moderate oversupply. In the sector, structural unemployment is more common in occupations requiring no qualifications.

In Slovakia, along with a decline in agricultural employment, unemployment of workers previously employed in agriculture - defined as agrarian unemployment (i.e. unemployed people last employed in agriculture) - declined as well. Following industry and construction, agriculture has 
become one of the main sources of unemployed persons in the Labour Offices. In some rural areas, this type of unemployment is becoming a difficult socio-political problem with multiplier effects on unemployment (the longer the persons are jobless, the less chance they have to find a job again). Long-term agrarian unemployment is becoming a problem in certain deprived areas and in certain social groups.

In 2005, according to the Central Office of Labour, Social Affairs and Family there 10.4 per cent of jobseekers were last employed in agriculture. In 2014, agriculture was the sector with the sixth highest number of jobseekers (5.0 per cent) registered in Labour Offices (Table 6). The difficult employability of this group has been affirmed for a long time. Certain options may be seen in the diversification potential of agricultural organisations, in the creation of alternative jobs in the place of residence and in small business development (especially in services) in their local community.

Table 6: Unemployed with last job in agriculture in Slovakia, 2001-2014.

\begin{tabular}{lccccccccc}
\hline \multicolumn{1}{c}{ Indicator } & $\mathbf{2 0 0 1}$ & $\mathbf{2 0 0 5}$ & $\mathbf{2 0 0 8}$ & $\mathbf{2 0 0 9}$ & $\mathbf{2 0 1 0}$ & $\mathbf{2 0 1 1}$ & $\mathbf{2 0 1 2}$ & $\mathbf{2 0 1 3}$ & $\mathbf{2 0 1 4}$ \\
\hline $\begin{array}{l}\text { Number of Jobseekers } \\
\text { by 31/12 }\end{array}$ & 41,140 & 21,462 & 10,096 & 11,898 & 11,497 & 10,609 & 8,203 & 7,654 & 6,729 \\
\hline $\begin{array}{l}\text { Share of the total sectorally } \\
\text { identified jobseekers (per cent) }\end{array}$ & 11.1 & 10.4 & 7.9 & 6.5 & 6.9 & 6.1 & 5.0 & 5.1 & 5.0 \\
\hline
\end{tabular}

Source: Central Office of Labour, Social Affairs and Family and NPPC-VÚEPP

\section{Opportunities for agricultural job creation}

The opportunities for increasing the agricultural labour demand under market conditions are strongly determined by the profitability of the agricultural sector as well as by the supports (and the taxes) to be paid. The rural development subsidies, that is, the measure to improve competitiveness through investments, the measure to maintain and/or improve environmental conditions through surplus labour demand, and subsidies to improve quality of life through increasing consumption or services are expected to stimulate an increase in employment. Measures in the frame of the CAP generally help to stabilise agricultural employment. The agricultural investments co-financed in the frame of supports provided by the Rural Development Programme help to bolster the competitiveness of agricultural enterprises and to maintain adequate employment. Special support for young farmers helps to manage the necessary generational change in the sector (Biró et al., 2016). For the continued market-based increase in agricultural employment, not only are the development of the labour intensive sectors, the atypical employment types and the expansion of multifunctional agriculture required, but enlarging the group of qualified labour, its continued training and the vertical extension of activities are also necessary.

\section{Labour intensive agricultural sectors}

All of the three counties' agricultural policy objectives are aimed at the development of labour intensive sectors (e.g. fruit and vegetables, livestock) to increase agricultural employment. In the Czech Republic there is a strong political effort to recover agricultural branches with higher labour input needs which have mostly declined significantly in the Czech Republic in recent years. Some of them are especially supported for this reason as "sensitive commodities" nowadays. Sowing areas of potatoes and vegetables declined rapidly to one third in the period 2000-2015. Increasing production would result in job creation. The total area of orchards in the Czech Republic seems to have stabilised at about 20 thousand hectares. But in fact many of the orchards are old and losing their production abilities, and activities in such orchards are ceasing. Their restoration would require high investment costs. The contemporary situation in the fruit market does not encourage potential investors 
sufficiently. This problem brings potential significant negative impacts on agricultural employment. The Czech Republic is a traditional and significant producer and exporter of hops. This commodity demands intensive labour input. The number of pigs (1.6 million in 2014) in the Czech Republic is less than half of that in 2000, in case of sows (about 100 thousand in 2014) it is only one third. Just sows require a lot of care from experienced and reliable breeders, so their breeding contributes significantly to agricultural employment.

In Hungary the Government launched the national programme of "More employment in agriculture!" for the labour intensive agricultural sectors in order to retain the jobs and create new employment, aiming to generate several thousand new jobs until 2020. In the increase in rural employment the 8-26 thousand AWU potential connected to agriculture can be based on the additional labour demand generated by the development of various labour intensive agricultural sectors. By considering the market prospects up to 2020 and by making use of the opportunities, 5-10 per cent additional output can be projected, depending on the sector. This increase in output might require considerable additional labour mainly in the fruit (5-11 thousand AWU), vegetable (2-5 thousand AWU) and wine (1-3 thousand AWU) sectors; while in livestock farming, in the pig, poultry and beef cattle sectors, there is only a modest potential for increase in employment even if the output increases (Biró and Székely et al., 2012).

The Slovak Government plans to increase the labour intensive fruit and vegetable production too. According to an estimate of the Slovak Vegetable Union: "In the case of increased sale of Slovak vegetables and fruit by 10 per cent, $4-5$ thousand new jobs will be established. In the last 10-15 years, the area of vegetables decreased from 30,000 ha to the current 9,400 ha. To change the situation, a range of measures must be accepted to make growing vegetables more attractive for farmers with appropriate support systems. Thus, in five years the area of orchards may be extended by 5,000 hectares. Each hectare of orchard requires one worker, and to this must be added the additional jobs in related activities. Furthermore, according to the Association of Vinedressers SR (2013) about 10,000 hectares of vineyards are currently being farmed, while Slovakia has negotiated a right to plant about 22,000 ha. That means the possibility to extend the area of vineyards by 12,000 hectares. As one worker for five hectares may be counted on, there is a chance to create about 2,400 jobs in primary production and other opportunities in the processing of grapes and in other related activities. Increasing the level of livestock production would also lead to an increase in agricultural employment. Since the constant increasing dependence of Slovakia on imports of meat and meat products (mainly pork and poultry) should be strengthened livestock production. Self-sufficiency rate has therefore a decreasing trend. An increase in pork production would create a significant number of sustainable jobs.

\section{New jobs in agriculture}

In Hungary in 2007-2013, the labour market supply was strengthened by measures for training and consultancy in the framework of Axis I of the NHRDP, while the preservation of local (rural) culture and traditions helped to acquire the utilisation of skills and knowledge measured in Axis III. The subsidies of Axis I focused on investments in agricultural production, and the development of technology rather resulted in lower demand for labour and the parameters and quality of human resources have not improved significantly (Hungarikum konzorcium, 2010). As a result of measures under Axis III. some long-term jobs have been created. The LEADER developments have provided opportunities for employment in LAGs. In agriculture, becoming entrepreneurs was promoted by the measure "setting up of young farmers". There was considerable interest in this measure: 5343 young farmers have gained an average of EUR 32.5 thousand in financial support.

In the Czech Republic the most efficient measure as to directly creating new jobs (in the frame of RDP 2007-2013) was the support for establishment and development of enterprises, support for touristic activities and also the diversification of activities of non-agricultural nature. All these 
measures are included in Axis III and altogether they helped to create more than 4 thousand new jobs (according to commitments of beneficiaries of supports). Another special measure (included in Axis I) directly supported the inflow of new young farmers into the sector - altogether 1.3 thousand young farmers used this opportunity.

In Slovakia an increasing number of persons employed in agriculture was positively influenced by measures aimed at job creation under the Rural Development Programme of the Slovak Republic (RDP) 2007-2013 (MARD of SR, 2015). By the end of 2014, 6,364 projects at a cost of EUR 1,263 million were approved under the project measures. There were 4,832 projects completed. The subsidies had a significant impact on maintaining employment and creating new jobs. Projects of the measure 3.1 "Diversification into non-agricultural activities" had created 531 new jobs by the end of 2014. Within the context of sectoral employment, the support from the RDP 2007-2013 has become an important motivation to maintain employment or to slow its decline.

\section{Socially-based job creation}

There are typical societal problems in the majority of the CEE countries such as the high share of the population that is in poverty and/or long-term unemployed, especially in the rural areas. While the proportion of people at risk of poverty ${ }^{5}$ was quite low in Slovakia (18.4 per cent) and the Czech Republic (14.8 per cent), it was 31.1 per cent in Hungary in 2014. The most disadvantaged population can generally be found in rural areas which are suitable for agricultural production but where the basic requirements of self-employment (land, capital and qualification) are missing the most. The situation might be improved by an increase in socially-based employment. Potential instruments may be special active labour market programmes, social land programmes, social cooperatives or municipal public work programmes in agriculture. Increased employment, in addition to the impacts on the labour market, also has broad economic and social consequences in the rural areas. The additional employment on a social basis has numerous economic and social benefits. The marginalised people will not only be prepared for agricultural production and subsistence but by improving their standards of living might also catch up and their economic and social activities might also be increased. In this way the younger generation living in persistent deep poverty might have a chance of breaking out (Biró and Székely et al., 2012).

In Hungary, social land programmes and public employment programmes played major roles in socially-based agricultural job creation, but the role of social cooperatives has also become stronger in recent years. Social land programmes have been operating in Hungary since 1992. The programme aimed to help small settlements and villages in the micro regions of low economic development and in disadvantageous situations. The main objective of the programme was to provide additional sources of income for unemployed or persistently inactive low-skilled people who were formerly linked to agricultural production (Biró and Székely et al., 2012). The main point of the programme was that the local resources of agricultural production (land, machinery) and the inputs required for the production (materials) should be provided as allowances in kind - by connecting these with the unused workforce of the families participating in the programme.

The number of settlements operating social land programmes annually ranges from 180 to 250 . The total amount of cultivated land area in social land programmes is about 4.5-5 thousand hectares, the majority of land is in municipal ownership or use (Márkusz and Tóth, 2010). The production structure of social land programmes is characterised by the dominance of high value added and labour-intensive vegetable and fruit production (Rácz, 2013). Experience shows that two main factors determine the successes/failures of the social land programmes: the activity of stakeholders (leaders and beneficiaries) and the market environment of produced products (Biró and Székely et al., 2012).

\footnotetext{
People at risk of poverty or social exclusion (people at risk of poverty or severely deprived or living in a household with low work intensity over the total population): total and by type of area (thinly-populated, intermediate urbanised and densely-populated) (EC, 2013b)
} 
The public employment programmes organised and funded by the state or local governments generally provide short-term (several months) work which fulfils public interest objectives. Public work is an active employment policy tool which touches most unemployed people in Hungary. It affected 208 thousand people in 2015. Typically, the older and less qualified long-term unemployed people are mobilised under the programmes so as not to lose their connections with the world of work permanently, and to retain their ability to work while they perform useful tasks for society. They get - covering their subsistence - an average amount corresponding to the minimum wage, public employment benefits are paid instead of aid. The majority of public employment positions do not require qualifications; they are only simple occupations. Of the 208 thousand public employees 2.6 per cent (5400 person) were in simple jobs in agriculture or forestry. There has been greater emphasis on sustainability because of the permanent expansion of employment in public work, this assertion serves the training of public workers ${ }^{6}$. The products which were produced by the participants were utilised in local catering and the fuel derived from forestry and land-use planning were utilised for the heating of public buildings.

Social cooperatives ${ }^{7}$ are supported in the EU and they are key players in the social economy of advanced countries. Their role is negligible in Hungary. These organisations, however, can be important tools for increasing employment related to agriculture and affecting the countryside. The creation of such cooperatives in Hungary was encouraged both by national and EU grants. EUR 3.1 million was paid from the Labour Market Fund to establish them between 2007 and 2011. These organisations have undertaken a number of tasks ${ }^{8}$ in connection to agriculture. Social cooperatives are currently estimated to employ 1000-1500 people. Social cooperatives or the wider interpreted social economy can play an important role in the expansion of agricultural employment by the creation of up to 5-10 thousand full-time job depending on changes in consumer demand.

In the Czech Republic, the Ministry of Agriculture launched the programme of social agriculture and assigned for it EUR 1.8 million for 2015. The aim of this programme is to create jobs for handicapped people (in terms of health or socially) on the labour market. Some similarly based jobs in agriculture are generated for instance by churches. In Slovakia the special public social land programme has not been established. The creation of new jobs has been carried out only through the Rural Development Programme 2007-2013.

\section{Conclusions}

The labour force in agriculture in Hungary, Slovakia and the Czech Republic has declined considerably since the beginning of the 1990s. This decline was not only related to limiting of agricultural production, but also as a result of the elimination of agricultural production cooperatives with the disappearance of non-agricultural activities. The application of modern technologies leading to reduced labour input, the simplification of the production structure, the specialisation and concentration as well as the higher incomes attainable and the more favourable working conditions in other sectors of the economy have speeded up the outflow of labour from agriculture.

The role of agriculture in employment in Hungary is significantly greater than in Slovakia and the Czech Republic. One important difference is that most of the agricultural labour is based on salaried labour - it means most people working in agriculture are employees - in the Czech Republic and in Slovakia, but in Hungary most of the agricultural labour is non-salaried family labour. Family farms are based primarily on self-employment, that is, on the best possible utilisation of the household's own labour, while corporate farms rely on full time salaried labour force. The labour productivity

\footnotetext{
The public workers learn crop production and livestock breeding for one year by the agricultural projects.

According to Act No. 10/2006 ,the social cooperatives aimed to create working conditions for its unemployed and socially disadvantaged members and otherwise to improve their social solution".

8 For example, processing agricultural products (drying, jam making, pumpkin seed oil pressing), collecting waste wood and by-products from forestry and agriculture, processing biomass etc.
} 
of farms employing salaried labour force seems to be higher than that of farms that use part-time employment and family labour. However, in order to increase the level of employment in agriculture by improving the utilisation of labour and increasing efficiency, developing the farms that are based on family labour is of outstanding importance.

In all of the three countries, one of the possible ways to increase agricultural employment is the development of labour intensive sectors. In order to make better use of employment potentials the challenge is to increase in parallel both the value-added and the level of employment as well as to encourage enterprise and to develop the economy to provide a base of innovations, new ideas and cooperation. In rural areas which are lagging behind in terms of social and economic conditions due to limited market-based employment opportunities and restricted resources, the emphasis could be put on the self-supplying and subsistence function of agriculture. In the context of the even worse social situation, among the three countries Hungary has the greatest tradition in the field of socialbased job creation programmes based on agriculture. 


\title{
Effects of Rural Development Programmes
}

\author{
BIRÓ, Szabolcs ${ }^{1}$, TÓTH, Orsolya1 ${ }^{1}, R A ́ C Z$, Katalin", \\ ČÁMSKÁ, Klára², VAJCÍKOVÁ, Ružena ${ }^{3}$, \\ ČıČOVÁ, Tatiana ${ }^{3}$ and FEDERIČOVÁ, Zuzana ${ }^{3}$
}

\section{Introduction}

Rural development plays a significant role in modernisation of farming, management of natural resources and revitalisation of rural areas. In this chapter, rural development during the last ten years in the three countries is summarised. Besides improving the competitiveness of agriculture, ensuring sustainable management of natural resources and public goods, the main target of rural development is to raise the quality of life in rural areas and to retain rural population (Potori et al., 2012). The combined result of the assessments of the rural development programmes showed that the effects are smaller than the former estimations (Fertő and Varga, 2013; Michalek and Zarnekow, 2012; Molnár et al., 2011).

\section{Pre-accession programmes (2000-2006)}

The Special Accession Programme for Agriculture and Rural Development (SAPARD) regulated by Council Regulation (EC) No 1268/1999 in the pre-accession period was the first rural development instrument of the EU assigned for the candidate countries to use the EU financial resources in the period 2000-2006, i.e. prior to joining the EU as full members. The aim of the programme was to help to introduce the law of the European Community in the area of agricultural policy in order to deal with priority and specific problems through permanently sustainable changes in the agricultural sector and in the rural areas of candidate countries. Another benefit of SAPARD was the opportunity to adopt the demanding regulations of EU Structural Funds and the principles of programming, building the required institutions and preparing a legislative framework and the conditions for monitoring the SAPARD programme. In order to implement the SAPARD Programme in the three countries, accredited Paying Agencies had to be established. During the course of the SAPARD Programme implementation, detailed procedures were introduced and officers at all stages of implementation gained valuable knowledge and skills related to the administration of EU structural funds, especially as regards control procedures and public procurement according to EU rules.

In all the three countries, SAPARD programme supports were mainly used for increasing competitiveness of agricultural production (58.1 per cent-63.5 per cent) and for the development of rural areas (34.6 per cent-36.5 per cent) (Table 1). In Slovakia the SAPARD Programme was divided into three priorities and nine measures. From the geographical point of view, all the measures of the Programme were applied in the whole territory of Slovakia.

Research Institute of Agricultural Economics, Budapest, Hungary.

Institute of Agricultural Economics and Information, Prague, Czech Republic.

National Agricultural and Food Centre - Research Institute of Agricultural and Food Economics, Bratislava, Slovak Republic. 
Table 1: Public expenditure of SAPARD programmes, 2000-2006.

\begin{tabular}{|c|c|c|}
\hline Priorities & EUR million & per cent \\
\hline \multicolumn{3}{|c|}{ Slovakia } \\
\hline 1. Improvement of agriculture and food industry & 65.8 & 63.5 \\
\hline 2. Sustainability of the rural development & 35.9 & 34.6 \\
\hline 3. Development of human activities & 0.8 & 0.8 \\
\hline Technical assistance & 1.2 & 1.2 \\
\hline Total & 103.7 & 100.0 \\
\hline \multicolumn{3}{|c|}{ Czech Republic } \\
\hline 1 Increasing the competitiveness of agriculture & 132.6 & 63.1 \\
\hline 2. Sustainable development of rural areas & 75.3 & 35.9 \\
\hline Technical assistance & 2.1 & 1.0 \\
\hline Total & 210.0 & 100.0 \\
\hline \multicolumn{3}{|c|}{ Hungary } \\
\hline 1 Improving the competitiveness of agriculture & 205.9 & 58.1 \\
\hline 2 Raising environmental awareness & 15.1 & 4.3 \\
\hline 3. Strengthening rural areas & 129.3 & 36.5 \\
\hline Technical assistance & 3.8 & 1.1 \\
\hline Total & 354.1 & 100.0 \\
\hline
\end{tabular}

Source: MPRV SR; MZe; Ministry of Agriculture and Rural Development (MARD)

Financial allocation of the European and national resources for Slovakia's SAPARD programme was EUR 103.7 million. Two main measures dominated with 538 approved projects and a budget of almost 65 per cent of all allocated financial support within Priority 1 (Improvement of the agricultural production sector, including food- processing industry). The shares of the approved financial obligation of Measure 1 (Investment in agricultural holdings) and Measure 2 (Improvement of processing and marketing of agricultural and fishery products) each exceeded 30 per cent of the total public programme expenditures for 2000-2004. There were 1,306 submitted project applications with a combined value of EUR 240.2 million. Finally, there were 904 contracted projects in total, which means that 69 per cent of project applications were approved and funding committed. The Managing Authority solved the high level of interest by allocating additional financial support from the financial framework of the Rural Development Plan (RDP) for the Slovak Republic 2004-2006 under Commission Regulation (EC) No 447/2004. The main objective of the programme was to improve the quality of life of the rural population, to ensure sufficient job opportunities and adequate incomes also for agriculturally disadvantaged areas (MPRV SR and RIAFE, 2008).

In the Czech Republic the four largest measures in the SAPARD programme in terms of public expenditure was Land improvement and parcelling (EUR 42.9 million), Improving the processing and marketing of agricultural and fishery products (EUR 35.7 million), Investments in agricultural holdings (EUR 34.8 million), and Development and diversification of economic activities, providing for multiple activities and alternative income (EUR 34.5 million). These accounted for 70.4 per cent of the public expenditure. The benefits of the SAPARD programme were mainly seen in the reconstruction and modernisation of animal production operations, the modernisation of storage technology, compliance with hygiene and veterinary standards, the renewal of ownership relationships, erosion protection as part of land consolidation, the development of farm tourism and the preservation of cultural heritage in the countryside. In addition to outputs related to operational objectives, the SAPARD Programme brought also numerous results: increased income of supported operators, 
increased labour productivity, rationalisation of production processes, effective use of production factors, positive effects on the environment and animal welfare, greater diversification, sustainability and attractiveness of economic activities in rural areas, higher competitiveness thanks to higher productivity and improved quality, improved working and public health conditions in plants, and new jobs, which has been particularly important in the regions suffering from high unemployment.

The objectives of the Hungarian SAPARD Programme promised integrated programme-based developments concentrating on sustainability, integration and human resources development. The implementation, however, focused on classical, intensive and competitive agriculture. From among the eight measures of the SAPARD Programme, only three were implemented as planned; these focused on the development of agricultural enterprises (39.2 per cent), on the development of the processing of agricultural and fishery products ( 28.3 per cent) and on the development of rural infrastructure (23.1 per cent). By implementing more than 2500 projects, the purchase of machinery of 76 thousand kilowatts, construction of grain storage capacity of 190 thousand tonnes, renewal of livestock farms for 88 thousand cattle and 450 thousand pigs as well as the maintenance or renewal of architectural heritage in 124 villages were financed.

\section{Post-accession programmes (2004-2006)}

In the period of 2004-2006 Council Regulation (EC) No 1257/1999 established the framework for Community support for rural development programmes. In Slovakia the Ministry of Agriculture in cooperation with the APA implemented two programmes co- financed from the European Agricultural Guidance and Guarantee Fund (EAGGF) and the Financial Instrument for Fisheries Guidance (FIFG) in parallel: Sectoral Operational Programme "Agriculture and Rural Development" of the SR 2004-2006 and RDP of the SR 2004-2006. The Sectoral Operational Programme Agriculture and Rural Development (SOP ARD) of the SR 2004-2006 represented the elaboration of one of the priority axes "Multifunctional agriculture and rural development" of the National Development Plan of SR for the period 2004-2006 and territorially related to the area falling within Objective 1 (other than the Bratislava region). EUR 181.2 million from the EAGGF guidance and of EUR 1.8 million from the FIFG were allocated (Table 2). By the end of 2007 the APA had received requested contributions under the programme for projects exceeding 194 per cent of the total financial limit. From the 1694 approved projects, 98 per cent were finalised by 2009. The most interest was noted in projects of Priority 1 Support of productive agriculture: Measure 1.1- Investments in agricultural holdings (62.6 per cent) and Measure 1.2- Improving processing and marketing of agricultural products (12 per cent). Priority 2 Support of sustainable rural development consisted of five measures: Sustainable forest management and forestry development, Fisheries, Promoting the adaptation and development of rural areas (e.g. Land consolidation and Diversification of agricultural activities), Training and Technical Assistance. This priority was less favoured in terms of projects and budget as well.

In the same period the RDP of the SR 2004-2006 established by Council Regulation (EC) No $1257 / 1999$ aimed to increase the profit in the agrarian sector, to maintain agricultural activities in disadvantaged areas, to elaborate and implement specific agro-environmental programmes, to intensify afforestation, to improve forest management and to enable farmers to meet the production and environmental standards. The Plan also supported greater economic viability of semi-subsistence farms and creation of producer groups. The main priorities of the RDP 2004-2006 were Priority 1 - Development of a sustainable rural economy and Priority 2 - Protection and improvement of the rural environment. RDP 2004-2006 only partially improved life quality because most subsidies were not allocated directly to rural areas but mostly to production assets of corporate organisations. The programmes improved the overall market situation for basic agricultural products, and in particular production and labour productivity increased, the technological level and production quality improved and diversity of production and services enlarged (MPRV SR and RIAFE, 2008). 
Table 2: Public expenditure for operational agriculture and rural development programmes, 2004-2006.

\begin{tabular}{|c|c|c|c|}
\hline & Programme & EUR million & per cent \\
\hline \multicolumn{4}{|c|}{ Slovakia } \\
\hline SOP ARD & & 361.6 & 41.0 \\
\hline RDP & & 520.7 & 59.0 \\
\hline Total & & 882.3 & 100.0 \\
\hline \multicolumn{4}{|c|}{ Czech Republic } \\
\hline Agriculture OP & & 256.6 & 27.4 \\
\hline HRDP & & 678.5 & 72.6 \\
\hline Total & & 935.1 & 100.0 \\
\hline \multicolumn{4}{|c|}{ Hungary } \\
\hline ARDOP & & 422.8 & 35.9 \\
\hline NRDP & & 754.1 & 64.1 \\
\hline Total & & $1,176.9$ & 100.0 \\
\hline
\end{tabular}

Source: MPRV SR; Ministry of Rural Development (MRD); MZe

In the Czech Republic the Operational Programme Rural Development and Multifunctional Agriculture (2004-2006) was jointly financed by the guidance section of the EAGGF and FIFG. Public funds of EUR 245.1 million from the EAGGF and of EUR 11.5 million from the FIFG were allocated. It covered the area of the Czech Republic apart from the City of Prague. The purpose of the Agriculture OP was to support agricultural primary production and the processing of agricultural products, to support forest and water management and to ensure the continually sustainable development of the countryside. Priority 1 Support to Agriculture, Processing of Agricultural Products and to Forestry had the highest budget, 60.0 per cent of the total allocation, while Priority 2 - Rural Development, Fisheries and Vocational Training had most of the rest (39.1 per cent). The share of the budget was the highest for the measures Investments in agricultural holdings (49.9 per cent) and Promoting the adaptation and development of rural areas (34.4 per cent).

To assess the degree of fulfilment of the global targets, two impact indicators were set, the development of the Czech population (without Prague) and the development of net value added of agricultural production. The population of the Czech Republic (including Prague) increased by almost 0.2 million persons (index 102.1 per cent) during the period. The increase in the rural population from 2001 was even more pronounced (index 102.4 per cent). On the other hand, there was a long-term weakening the position of the primary sector in the economy, which was also reflected in the continuous fall in employment. Based on the above facts it can be assumed that the population growth in rural communities was strongly influenced by factors other than developments in agriculture, and that these factors were associated primarily with the development of urbanisation in the residential agglomerations and big cities. The second indicator evaluated the actual performance of the agricultural sector (measured by net value added at constant prices 2000). In this case, the development was slightly less favourable than the underlying assumptions. Net value added remained in comparison with 2001 at almost on the same level (index 100.2), while the planned target value was not fully achieved (index 95.5 per cent) (MZe, 2010).

The RDP of the Czech Republic (2004-2007) started in 2004. Its main objective was to ensure the sustainable development of agriculture, the countryside and its natural resources. The largest share in the total financial allocation was the agro-environmental measures (52.4 per cent of support) and support for less favoured areas (40.7 per cent of support). Within the framework of the 
programme, in the period 2004-2007 applicants could submit applications for grants related to four measures (Early retirement, Agro-environmental, Forestry and Setting up of producer groups) and in the period 2004-2006 for Less-favoured areas supports. According to the ex-post evaluation (MZe, 2009), the agro-environmental measures contributed to maintaining and encouraging conservation in agricultural operations, to positive changes in land use, to a decrease in the use of inorganic fertiliser and chemical products on arable crops and grassland, and to supporting biodiversity. Measures supported forestry - the social or economic influence of these measures was mostly apparent in the initial phase, when there was a noticeable increase in short-term (seasonal) employment, especially with the sub-measure Planting of fast-growing timber species for use in energy production. The social impact of the measures included the increased attractiveness of the landscape. The payments for less favoured areas were intended to ensure the viability of farms that otherwise would not be competitive and whose farming would be in jeopardy from natural and/or climatic reasons. Gross income from agriculture increased in mountain regions, where it is most difficult to maintain employment rates in agriculture. The Early retirement schemes and Setting up of producer groups measures also had positive results.

In Hungary the Agricultural and Rural Development Operational Programme (ARDOP) 20042007 mainly supported the modernisation and the upgrading of the technical conditions in agriculture but also to a certain degree contributed to increasing rural incomes, renewing buildings and improving the human conditions of production. ARDOP had the priority role in the adjustment and reduction of territorial disparities ensuing from disparities in conditions of agricultural production, resolving rural social problems, sustaining and conserving ecological and natural values, as well as the protection of the environment. Public funds of EUR 422.8 million (EUR 411.3 million from the EAGGF guidance and of EUR 11.5 million from the FIFG) were allocated. Priority 1 "Establishing competitive raw material production in agriculture" accounted for the largest share ( 58 per cent). Priority 2 "Modernisation of food processing" accounted for 14 per cent and Priority 3 "Development of rural areas" amounted to 25.5 per cent of total support. The results of ARDOP are the following: purchase of machinery of a total of 128 thousand kilowatts, the construction and renewal of livestock farms for 26 thousand cattle and for 343 thousand pigs (MRD, 2010). In the National Rural Development Programme (NRDP) 2004-2007 with public funds of EUR 754.1 million, Agro-environmental and Afforestation measures accounted for 82.9 per cent of the total budget. The measures of the NRDP mainly raised awareness and had an opinion forming effect as well as contributing to improving the environment and the quality of life in rural areas. Through the NRDP measures, annually about 35 thousand farmers received subsidies. The agro-environmental measures used two thirds of the budget by providing subsidies to 24 thousand farmers for environmentally-friendly production. The total area affected was 1.5 million hectares (Respect, 2009).

\section{The first full-term programmes (2007-2013)}

For the EU Member States in the period 2007-2013 the CAP set out the rules and procedures in agriculture, with the second pillar supporting rural development. Council Regulation (EC) No. 1698/2005 laid down the support framework for sustainable rural development while the rural development measures complemented and accompanied the first pillar instruments of the CAP. The European Agricultural Fund for Rural Development (EAFRD) was established by Council Regulation (EC) No 1290/2005.

In Slovakia, the Rural Development Programme (RDP) of the Slovak Republic 2007-2013 was established. The global objective of the programme was sustainable development of the rural areas. It may be achieved by development of economic activities, protection of the environment and the cultural heritage and improvement of the quality of life of the rural population. Within the RDP 20072013 four main axes were set: Axis I - Improving the competitiveness of the agricultural and forestry 
sector, Axis II - Improving the environment and the countryside, Axis III - Quality of life in rural areas and diversification of the rural economy, Axis IV - Implementation of the Leader approach, with an additional financial allocation for Technical assistance (MARD, 2009). In Slovakia, 44.4 per cent of the RDP budget was allocated to Axis 1 (EUR 1,544.9 million); 36.6 per cent to Axis 2 (EUR 1,273.3 million), 14.3 per cent to Axis 3 (EUR 498.2 million) and 3,1 per cent to Axis 4 (EUR 107.8 million), with 1.6 per cent available to fund Technical Assistance (EUR 56.3 million).

With the purpose of drawing down EU funding the Czech Republic prepared a basic strategic document - the National Strategic RDP of the Czech Republic for the period 2007-2013 and later the programme document - Rural Development Programme of the Czech Republic for the period 20072013 which specified in detail the measures for meeting the objectives of the development of rural areas. Rural Development Programme measures assisted in achieving the goals of the Lisbon Strategy in all its areas: society based on knowledge, internal market and business environment, labour market and sustainable development. For the whole programming period, EUR 3,669.8 million of public funds were allocated. The programme consisted of four basic axes, i.e. groups of measures: Improving the competitiveness of the agricultural, food and forestry sectors - Axis I (23.4 per cent of total public expenditure), Increasing biodiversity, water and soil protection and mitigating climate change - Axis II (52.9 per cent of total public expenditure). The task of Axis III was to improve the quality of life in rural areas and to encourage the diversification of economic activities (17.6 per cent of total public expenditure). The objective of Axis IV (5.6 per cent of total public expenditure) was helping the residents of rural micro-regions to apply the 'bottom up' principle to work out their local development strategy (LDS) and to support the projects concerning development of the region with the so called LEADER method.

In Hungary the Ignác Darányi - New Hungary Rural Development Plan (NHRDP) 2007-2013 focused on investment promotion and on increasing those environmental services which generate agricultural surplus income. In the programme budget, finance was allocated to measures for increasing directly the competitiveness of food processing (51.2 per cent), maintaining and improving the rural environment (32.4 per cent), as well as improving the quality of life in rural areas (13.1 per cent) and implementing the objectives of LEADER (3.3 per cent). In the NHRDP - despite the fact that two measures, the modernisation of farms and the agro-environmental measures, accounted for half of the total budget - with its more diversified structure the 11 most significant measures account for three-quarters of the total budget of EUR 5,159.1 million (MRD, 2013a). The implementation of the programme was determined by the general economic environment. By evaluating the investments implemented by subsidies under Axis I of the NHRDP, the market-oriented use of the funds seems to have been extremely risky since the economic depression. The average NHRDP subsidy is EUR 16.7 million per LAU 1 micro-region but the northern regions of Hungary and the regions of Transdanubia received a smaller share and the majority of the funding has flowed into the regions of the Great Plain. In addition, the more prominent regions of the Great Plain with traditional agricultural activity have an outstanding resource absorbing capacity (Figure 1). The main reason is that the subsidies from Axes I and II flowed into those micro-regions where there were a large number of farmers with large land area (over 50 hectares) and livestock (over one thousand Livestock Units). The relationship shows a strong correlation $(\mathrm{R}=0.72)$. 
Figure 1: Distribution of NHRDP subsidies by micro-regions in Hungary, 2007-2013.

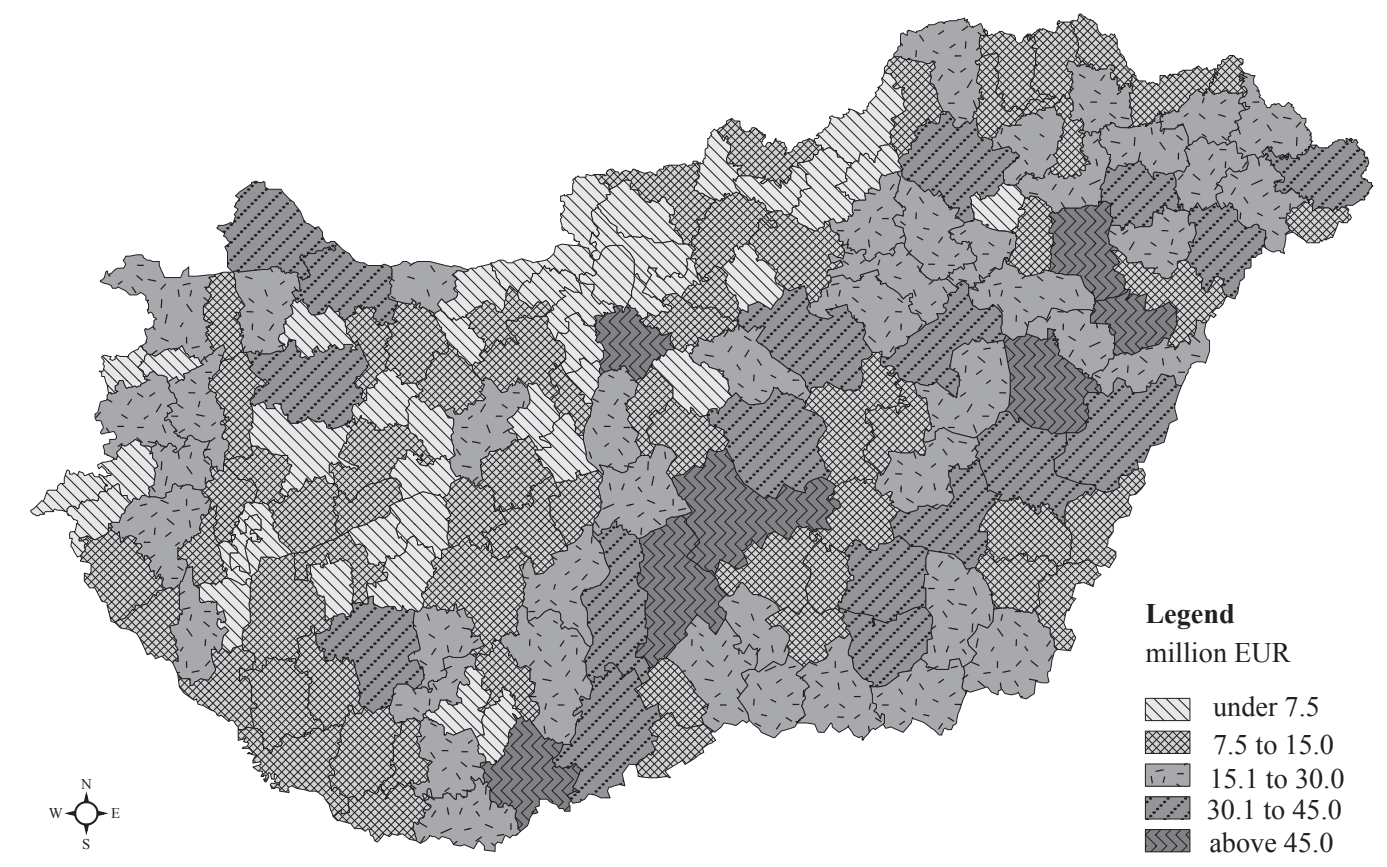

Source: Based on data of APA

\section{Main results of RDPs 2007-2013}

\section{AXIS I: Improving the Competitiveness of the Agricultural and Forestry Sector}

In Slovakia, the greatest interest in Axis I was in the measure "Modernisation of agricultural holdings" (NAFC et al., 2015). Up to 45 per cent of all approved applications in Axis I came from this measure; EUR 439.5 million of public funds were approved for this measure (54.8 per cent of the approved allocation for the Axis) by the end of 2014 and 1,420 projects were completed at that time. Among the 1,268 business holdings supported, 29.8 per cent were natural persons. Payments of EUR 386.4 million were realised, with most public expenditure targeting mechanisation (55.6 per cent) and investments in buildings (44.4 per cent). More than half (53.5 per cent) of the public funds paid out were allocated to agriculturally less favoured areas (mountain and other areas). The second largest measure in terms of approved funds was the measure "Adding value to agricultural and forestry products". At the end of 2014, there were 396 approved projects amounting to EUR 199.3 million, which represents up to 97 per cent of all contracting. Of these approved projects, 339 were on food production and 57 on forestry. Average public funds per enterprise in the food industry were about 8.6 times higher than in forestry and targeted mainly the cereals and products of the milling industry, pulses and oil seeds sectors. On the basis of the objectives it is assumed that every second supported holding introduced new production processes or new products. Investments in production value changed at a high rate, 86 per cent of supported holdings have already achieved the expected results so far.

In the Czech Republic, the measure "Modernisation of agricultural holdings", with 3,184 approved projects and EUR 278.8 million expenditure, showed only minor gross value added increase (around EUR 60 on average per project). Nearly three quarters of the projects were about construction or reconstruction of buildings, mostly for livestock. More than one third of the projects were connected 
to organic agriculture on mixed crop and livestock production or grazing livestock farms. Under the measure "Adding value to agricultural and food products", with 897 approved projects and EUR 83.1 million expenditure, prevailed food firms with a focus on the winery business. A slight positive effect in terms of the proportion of sales of own products and services in total output was proved; supported businesses were better off placing their products on the market. The changes in GVA of supported enterprises showed less development (19.0 per cent) than did agriculture overall (39.8 per cent), mainly due to favourable price developments of agrarian products. There was a wide range of innovative projects, from the optimisation of production processes through technological innovation to improved quality and durability of food up to the design of new products. Half of the completed projects were focused on meat and meat products, and about one third focused on the processing of milk and dairy products. The measure "Training and education" involved 88 thousand participants, significantly exceeding the original target. Three quarters of them were trained in the agricultural sector, 20 per cent attended informational and educational events in the food sector, and 5 per cent in forestry. Advisory services were provided to 3,764 farmers and 424 land owners or tenants of the forest. The majority of projects of consulting services were to be directed primarily at minimum management requirements and the environment. The measure "Setting up of young farmers" attracted 1,387 new entrants to farming business.

In Hungary the measure of modernisation of agricultural holdings of Axis I, which provided for purchasing machinery and technologies not requiring construction of buildings (8.6 thousand approved applications for subsidies of EUR 31.5 thousand on average), improved the age structure of the machinery and encouraged the purchase of energy-saving equipment. Subsidies were financed also for the modernisation of the post-harvesting facilities (522 approved applications for subsidies of EUR 165.2 thousand on average). In the frame of the measure of modernisation of the facilities of livestock farms (2.3 thousand approved applications for subsidies of EUR 428.9 thousand on average, for poultry farms (46 approved applications for average subsidies of EUR 176.3 thousand), livestock farmers could make use of the complex infrastructural subsidies. In connection with the subsidies provided for horticulture (219 thousand approved applications for subsidies of EUR 291.1 thousand on average), facilities for horticultural activities were developed. In addition to mechanisation (4.4 thousand approved applications for subsidies of EUR 24.4 thousand on average), the improvement of plantations (210 approved applications for subsidies of EUR 103.3 thousand on average) also increased the efficiency of the sector. The increase in the value of agricultural products measure (635 thousand approved applications for subsidies of EUR 433 thousand on average) resulted in improved competitiveness, restructured the production structure and in developments in food safety and energy saving. In the measure of infrastructure development irrigation, melioration and the construction of the buildings of the regional water management (377 approved applications for subsidies of EUR 199.3 thousand on average) and of agricultural roads (159 approved applications for subsidies of EUR 247.4 thousand on average) were included. In the frame of the measure of extension services about 14 thousand farmers and forest owners could use this service for EUR 700 up to three times per year (29.2 thousand approved applications for subsidies of EUR 500 on average). From the training and information activities 54.7 thousand farmers used the information service and 80 thousand people received professional training. From agricultural restructuring subsidies 3.3 thousand young farmers benefited. (MRD, 2013b)

In Hungary, owing to the need to comply with EU regulations, investments were mainly required for renovating and upgrading the existing outdated and depreciated capacities rather than for new technologies that would increase the added value and expand sustainable agricultural employment AKI evaluation (2014). The concentrated production increase raised also the demand for labour. The greater capacity use improved the economies of scale and increased productivity. The farmers of various land size categories obtained subsidies of similar values (Table 3 ). 
Table 3: Main measures of Axis I of the NHRDP by farm size categories, 2007-2013.

\begin{tabular}{lrrrrrrrr}
\hline \multirow{2}{*}{ Measure } & \multicolumn{2}{c}{$\begin{array}{c}\text { Less than 50 } \\
\text { hectare }\end{array}$} & \multicolumn{2}{c}{$\mathbf{5 0}$ to 500 hectare } & \multicolumn{2}{c}{$\begin{array}{c}\text { More than 500 } \\
\text { hectare }\end{array}$} & \multicolumn{2}{c}{ Total } \\
\cline { 2 - 9 } & $\begin{array}{c}\text { EUR } \\
\text { million }\end{array}$ & per cent & $\begin{array}{c}\text { EUR } \\
\text { million }\end{array}$ & per cent & $\begin{array}{c}\text { EUR } \\
\text { million }\end{array}$ & per cent & $\begin{array}{c}\text { EUR } \\
\text { million }\end{array}$ & per cent \\
\hline Training and extension & 15.9 & 75.9 & 4.1 & 20.2 & 0.7 & 4.0 & 21.1 & 100.0 \\
\hline Subsidies to young farmers & 113.0 & 94.5 & 6.7 & 5.5 & 0.0 & 0.0 & 119.6 & 100.0 \\
\hline $\begin{array}{l}\text { Machinery, technological } \\
\text { devices }\end{array}$ & 80.4 & 32.5 & 83.7 & 34 & 82.6 & 33.5 & 246.7 & 100.0 \\
\hline Crop production facilities & 52.6 & 45.8 & 21.9 & 19.1 & 40.0 & 35.1 & 114.4 & 100.0 \\
\hline $\begin{array}{l}\text { Modernisation of livestock } \\
\text { farms }\end{array}$ & 242.6 & 38.2 & 117.8 & 18.5 & 274.8 & 43.3 & 635.6 & 100.0 \\
\hline Horticulture development & 41.5 & 60.2 & 19.3 & 28.2 & 8.1 & 11.7 & 68.9 & 100.0 \\
\hline Infrastructure development & 50.4 & 64.9 & 12.6 & 16.1 & 14.8 & 19.0 & 77.8 & 100.0 \\
\hline Main measures Axis I & 596.7 & 46.5 & 266.3 & 20.7 & 421.5 & 32.8 & 1284.4 & 100.0 \\
\hline
\end{tabular}

Source: AKI, 2014

\section{AXIS II: Improving the Environment and the Countryside}

Subsidies for the Axis II measures were paid mostly for the area or livestock units. The effectiveness of using public funds is not measured in terms of economic parameters, but in terms of area with successful landscape management. It is expected that successful management reflects the fulfilment of the conditions required by the measure or assumed commitment. Area determines the extent to increase biodiversity, improve water and soil quality, reduce climate changes and prevent the marginalisation of the territory.

In Slovakia, from the territorial point of view the most extensive support was targeted to less favoured areas totalling 1,246 thousand hectares, where payments primarily contribute to prevention of backwardness. The synergistically largest environmental effect is achieved by Agro-environmental support to 388.9 thousand new and 495.5 thousand hectares of ongoing commitments from the RDP 2004-2006 and by Restoring forestry potential and introducing prevention actions on 376.2 thousand hectares (Table 4). Since 2007-2014, the cumulative implementation of measures within the LFA supported 7,132 farms, of which 3,458 were in mountain areas with an area of 472.8 thousand hectares, and 3,674 in other handicapped areas with an area of 772.7 thousand hectares. The average aid per ha of agricultural land in mountainous areas is EUR 659, in other handicapped areas EUR 312 and in specifically handicapped areas EUR 250. The total amount paid under the measure LFA reached EUR 666 million at the end of 2014. In the measure Agro-environmental payments (AEP) 1,252 businesses were supported through 2,069 contracts. The total new commitment area reached 388.9 thousand ha. When comparing the regional placement of AEP, the overlay with LFA is around 75 per cent of the area. At the same time, from the beginning of RDP implementation 4,924 livestock units of endangered animals (cattle breeds, horses, sheep and goats) were supported Within the measure Restoring forestry potential and introducing prevention actions there were 375 projects supported at a cost of EUR 128.5 million by the end of 2014. Total supported area of damaged forests reached 376.0 thousand ha. The supported projects were concentrated mainly on renewal of production potential of forests damaged by natural disasters (191.9 thousand ha) and to prevent forest fire (181.5 thousand ha). 
Table 4: Area and result indicators of Axis II measures in Slovakia, 2014.

\begin{tabular}{|c|c|c|c|c|c|c|}
\hline \multirow[b]{2}{*}{ Measure } & \multirow[b]{2}{*}{$\begin{array}{l}\text { Total area } \\
\text { (thousand } \\
\text { ha) }\end{array}$} & \multicolumn{5}{|c|}{ per cent with the aim of enhancing } \\
\hline & & $\begin{array}{l}\text { Biodiver- } \\
\text { sity }\end{array}$ & $\begin{array}{l}\text { Water } \\
\text { quality }\end{array}$ & $\begin{array}{l}\text { Mitigate } \\
\text { climate } \\
\text { change }\end{array}$ & $\begin{array}{c}\text { Soil } \\
\text { quality }\end{array}$ & $\begin{array}{l}\text { Avoidance } \\
\text { of land } \\
\text { abandon- } \\
\text { ment } \\
\end{array}$ \\
\hline LFA payments & $1,245.5$ & 16.3 & 0.0 & 0.0 & 0.0 & 100.0 \\
\hline $\begin{array}{l}\text { Natura } 2000 \text { and Directive } \\
\text { 2000/60/EC payments }\end{array}$ & 0.4 & 100.0 & 100.0 & 100.0 & 100.0 & 100.0 \\
\hline Agri-environmental payments ${ }^{\text {a) }}$ & 884.4 & 44.5 & 96.2 & 93.6 & 82.9 & 100.0 \\
\hline Afforestation $^{\text {a) }}$ & 0.2 & 100.0 & 100.0 & 100.0 & 100.0 & 100.0 \\
\hline Natura 2000 forest payments & 17.5 & 100.0 & 100.0 & 100.0 & 100.0 & 100.0 \\
\hline Forest-environment payments & 14.6 & 100.0 & 100.0 & 100.0 & 100.0 & 100.0 \\
\hline $\begin{array}{l}\text { Restoring forestry potential } \\
\text { and introducing prevention } \\
\text { actions }\end{array}$ & 376.2 & 100.0 & 100.0 & 52.8 & 99.6 & 0.0 \\
\hline Total $^{\text {a) }}$ & $2,575.8$ & 39.0 & 48.9 & 41.1 & 44.3 & 84.0 \\
\hline
\end{tabular}

a) With ongoing commitments of RDP 2004-2006.

Source: NAFC et al., 2015

Axis II in the Czech Republic contained three priorities and its share of total EAFRD fund allocation amounted to 55.2 per cent. The Priority Biodiversity, conservation and development of agricultural and forestry systems with a high added value and traditional agricultural landscapes supported increasing the biodiversity, development of traditional landscapes and the conservation of natural resources. For this priority 80.1 per cent of Axis II resources were allocated. The second priority Water and soil protection supported the protection of natural water regime quality in the landscape using suitable agricultural systems (with 14.8 per cent of Axis II resources). The third priority Mitigation of climate changes supported cultivation of renewable energy sources, reducing the emission of greenhouse gases and maintaining forest functions (5.1 per cent of Axis II resources were dedicated). "Agro-environmental" measures affected 13,120 farms and 1,075 thousand hectares. The "Environmentally friendly farming" sub-measure supported complex management methods providing the base for production of quality raw material and ensuring compliance with the highest requirements for food safety with Organic farming and Integrated production schemes. The "Grassland maintenance" sub-measure provided support for targeted management of parcels according to the natural conditions or applied grassland management. The "Landscape management" sub-measure also encompassed schemes suitable for special conditions. Conversion of arable land to grassland and Growing of catch crops schemes were introduced to decrease soil erosion risk. The main objective of the scheme "Bio-belts" was increasing the food offer and therefore support for the development of bird communities and other animal species bound to field habitats and ecosystems connected with field localities. Several measures of Axis II were focused on the sustainable management of forests. LFA payments were monitored in the interim evaluation (DHV, 2013). LFA payments contributed to the continuity of land management in the mountainous and specific areas, maintaining people working in agriculture.

In Hungary, the payments for various environmental projects in Axis II of the NHRDP contributed to increased agricultural incomes on 1760.8 thousand hectares by providing environmental services for all of society (Körtáj Tervezö Iroda, 2013). The main objectives of the measures were to support the sustainable development of rural areas, preserve and improve the environment, reduce the environmental impact of agricultural origin, provide environmental services, and strengthen agricultural practices based on the sustainable use of natural resources. The land use for environmental purposes 
concentrates mainly on maintaining soil quality (28.3 per cent), conserving biodiversity (23.2 per cent) and preserving water quality (22.6 per cent). On the basis of the impacts further efforts are required since biodiversity is significantly declining and, without subsidies, maintaining the agricultural land (2.8 million hectares) and forests (964 thousand hectares) of high nature value is not possible. At the national level, owing to reduced nutrient inputs, substantial improvement of the quality of surface water could not be measured. The dynamics of afforestation fell significantly, therefore, in the fight against climate change no major result could be reached.

\section{AXIS III: Quality of Life in Rural Areas and Diversification of the Rural Economy}

In Slovakia the most important measure of Axis III was measure Diversification into non-agricultural activities. By the end of 2014, 229 projects were approved, their value amounted to EUR 100.6 million of public funds. Three quarters ( 73 per cent) of the approved projects were oriented to tourism, 11 per cent to retail activities, 10 per cent to renewable energy production and 6 per cent to other activities. Tourism absorbed nearly two-thirds of the total investment budget. Under the measure Basic services for rural population, 597 contracts were made. EUR 93.9 million of funds were approved. Almost 89 per cent of projects are oriented to cultural and social infrastructure, with activities of reconstruction and modernisation of local infrastructure, buildings and objects of social significance (e.g. municipal offices, culture houses etc). Another important measure was Village Renewal and Development. There were 537 projects with EUR 93.7 million of public funds approved. Data show that 308 thousand rural residents benefited from realised and completed projects (NAFC et al., 2015).

In the Czech Republic Axis III was divided into three priorities. Priority Creation of employment opportunities and support of renewable energy sources: the share of financial resources in the framework of Axis III was 50 per cent for this priority, while the main emphasis was placed on diversification of agricultural activities, support for establishment of enterprises and support for tourism. In the framework of diversification of agricultural activities, a particular goal was the support of energy self-sufficiency of the countryside and reaching the Czech Republic commitment to achieve 8 per cent of energy from renewable resources. The priority was oriented towards securing compensation for an expected decline in jobs in agriculture and the food sector, and therefore fulfilment of the Lisbon Strategy goals. The priority Conditions of growth and quality of life in the countryside was oriented to improving conditions such as infrastructure, water purity in municipalities, cultural and social infrastructure. The largest share of financial resources in the framework of Axis III was allocated for this priority (48 per cent). The priority Education was aimed at the education and information of business entities to which Axis III was applied. The priority has 2 per cent of the total allocation of Axis III. The distribution of projects and public expenditures of Axis III measures are shown in Table 5.

In the case of measure Diversification into non-agricultural activities, almost 90 per cent of funds were directed to renewable energy, and the same proportion corresponded to the amount of total investment in renewable energy. A positive result was that all recipients reported an increase in turnover. In the successfully implemented projects the manufacturing industry with higher added value dominated (67 per cent). For the measure Encouragement of tourist activities, $372 \mathrm{~km}$ of hiking trails and $11 \mathrm{~km}$ of wine trails were realised within 81 supported projects aimed at building hiking trails and roads. Most of the completed projects ( 80 per cent) focused on the construction or refurbishment of accommodation and catering facilities, bed capacity projects supported 5,249 beds. Under the measure Village renewal and development, the most complex projects ( 85 per cent) were focused on the infrastructure in public spaces, including, for example, reconstruction of local roads together with stops for public transport, lighting, village greens etc. On the financial side, however, the shares of subsidies provided to improve the appearance of the village and the water infrastructure were equal 
(about 50 per cent). Through the implemented projects under the measure Public amenities and services, Internet was made available to nearly 30 thousand persons and the realised actions contributed to the improvement of facilities and the use of the variety of services in rural areas. In the case of the Measure Conservation of cultural heritage, the majority of projects focused on support for building restoration and enhancement of rural heritage. The number of people utilising the service improvement reached nearly 650 thousand persons.

Table 5: Axis III measures approved projects and public expenditures in the Czech Republic, 2007-2013.

\begin{tabular}{lrrrr}
\hline \multicolumn{1}{c}{ Measure } & $\begin{array}{c}\text { Number of } \\
\text { projects }\end{array}$ & per cent & EUR million & per cent \\
\hline Diversification into non-agricultural activities & 475 & 10.6 & 145.4 & 22.2 \\
\hline Support for business creation and development & 1,170 & 26.1 & 96.3 & 14.7 \\
\hline Encouragement of tourism activities & 677 & 15.1 & 77.6 & 11.9 \\
\hline Public amenities and services & 271 & 6.1 & 55.3 & 8.4 \\
\hline Village renewal and development & 1,129 & 25.2 & 218 & 33.3 \\
\hline Conservation of the rural cultural heritage & 657 & 14.7 & 59.6 & 9.1 \\
\hline Training and information & 99 & 2.2 & 2.6 & 0.4 \\
\hline Total & 4,478 & 100.0 & 654.8 & 100.0 \\
\hline
\end{tabular}

Source: MZe

In Hungary the main objective of Axis III of the NHRDP was the development and diversification of the rural economy and the improvement of the quality of life in rural areas. By taking into account the absorption capacities it is evident that the rural population needs developments in basic services rather than those requiring entrepreneurial, risk taking and innovation skills and ideas. Cohesion of the rural communities is also an important part of rural development. The most important result of the LEADER-approach is that in rural areas, based on the cooperation of the local governments, the enterprises and civil organisations, Local Action Groups of national coverage were organised for implementing the demands of the local population in development. In Axis III, in the frame of the measure Encouragement of tourism activities (313) requiring the largest budget (EUR 139.3 million), about 1500 new tourism activities (e.g. access to natural areas, establishment of accommodation places of low capacity, marketing) were supported by increasing slightly the employment. In the frame of the other major measure of Axis III (EUR 134.3 million), that is, Basic services for the economy and rural population (321), 493 multiple service centres and 1069 micro-transport services were supported by creating 138 new jobs. In the frame of the measure Village renewal and development (322), which was popular also in the previous programming period, activities to the value of EUR 105.2 million, relating mainly to infrastructural developments and encouraging rural societies, were implemented in 2816 settlements. Under the measure Support for business creation and development (312), 1874 micro-enterprises received financing to the value of EUR 90 million from among which 1180 were new enterprises. The number of jobs (up to 2014) created by the measure was 911.5 FTE (Managing Authority of NHRD, 2015).

\section{AXIS IV: Implementation of the LEADER Approach}

A final user of the LEADER approach is the local partnership composed of the public, entrepreneurial and social sectors, namely the Local Action Group (LAG). The LAG defines its own region in which will implement its activities and thereby fulfil the objectives determined in the LDS. The advantages of the LEADER approach are the cooperation and also the voluntary activity in the rural areas. 
In Slovakia, LAGs announce the calls for projects. The LAG submits a report on the selection of grant applications after the completion of the evaluation for each closed call. The APA subsequently carries out an administrative check on all received applications. The APA accepted projects of Axis III are implemented through Axis IV LEADER to a value of 127 per cent (requested contribution) of the public expenditure limit to the end of 2014. Implementation of measure 431 Running the local action group is shown in Table 6 . There were also 35 cooperation projects supported with 50 cooperating LAGs. There were 14 inter-district projects (with 26 cooperating LAGs) to the value of EUR 476.1 thousand and 21 trans-national projects (with 24 cooperating LAG) for which the total amount of public expenditure was EUR 664.9 thousand.

Table 6: Implementation of the measure 431 Running the local action group by activity, 2007-2014.

\begin{tabular}{lcrcr}
\hline \multicolumn{1}{c}{ Activity } & $\begin{array}{c}\text { Number of } \\
\text { projects }\end{array}$ & per cent & $\begin{array}{c}\text { Public } \\
\text { expenditure, } \\
\text { EUR } \\
\text { thousand }\end{array}$ & per cent \\
\hline Studies of relevant areas & 25 & 0.9 & 266.0 & 2.8 \\
\hline $\begin{array}{l}\text { Measures to provide information about the } \\
\text { area and the LDS }\end{array}$ & 832 & 28.7 & 853.6 & 9.0 \\
\hline Training of staff preparing, implementing LDS & 928 & 32.0 & 393.2 & 4.1 \\
\hline Promotional events & 457 & 15.8 & 305.2 & 3.2 \\
\hline Other & 659 & 22.7 & $7,716.0$ & 80.9 \\
\hline Total & 2,901 & 100.0 & $9,534.0$ & 100.0 \\
\hline
\end{tabular}

Source: NAFC et al., 2015

In the Czech Republic the SAPARD Programme already enabled 210 local development strategies to be prepared and implemented. The first 29 LAGs have been gaining experience within LEADER+ sub-measure of the Operational Programme "Rural Development and Multifunctional Agriculture", and the national programme, LEADER CR, since 2004 and 2005. Within this measure, LAGs implemented their strategic plans. The main aim of the support was increasing the competitiveness of agriculture and forestry as well as improving the quality of life in rural areas and the diversification of economy through an introduction of LDS into the system of rural development programmes and application of LEADER principles. In 2013, 112 LAGs were supported across a territory of 49,826 square kilometres with a total population of 3,670 thousand people. By the end of 2013, 6,267 projects were completed. The vast majority of projects administered through the LAG were focused on measures of Axis III (5,539 projects). Most projects were implemented in relation to Civic amenities and services and Village renewal and development (2,598 and 1,295 projects). Projects with primary measures of Axis I ( 719 completed projects) have been directed overwhelmingly to the measure Modernisation of agricultural holdings (583 projects), as well as to the measure Adding value to agricultural and food products (73 projects) and Investments in forests (60 projects).

In Hungary, rural development policy is actively facilitated by a new network of LEADER LAGs established at micro-regional level. By linking central support and local opportunities these organisations, established to create programmes, organise society and develop projects, were supposed to ensure sources are exploited as efficiently as possible. AAM Group (2013) studied the impacts of NHRDP Axis III and IV. In terms of GVA, micro-level analyses of business associations showed that in supporting micro-enterprises each EUR 1,000 added on average EUR 339 to the GVA value of beneficiary enterprises. Payments to private enterprises translated into even more significant growth, as the turnover from sales in the targeted group in 2012 was 54 per cent higher than that of the control group. As far as FTE is concerned, for each EUR 10 thousand payment increased employment by 2.7 FTE on average, resulting in a total FTE increase of 832.5 in the country. 


\section{The current programmes (2014-2020)}

The rural development subsidies in the current programming period will mainly support the improvement of the competitiveness of small and medium size enterprises in agriculture and forestry. The flexibility of the CAP rural development policy depends on the limits of the economic reality, the new challenges and the experience gained during earlier programmes. In the light of all these, changes can be forecasted which do not alter the delicate balance established in different areas, but which take advantage of the changes and the possibility of adjustment in the new planning period (Matthews, 2012). The implementation mechanism is based on a strategic approach; the key elements are the clearly defined common priorities and the related objectives to be applied by all Member States as well as the adjustments required based on earlier experience. From the CAP reform scenarios, for the period 2014-2020 the one relating to integration prevailed; the main objectives of which (Potori et al., 2012) are: efficient, equitable and targeted allocation of resources; the "greening" of the payments, providing assistance to the competitiveness of the sector, to sustainable development, to innovation as well as to encouraging the cooperation and providing support for the adaptation to the new environmental challenges.

In the new framework, in accordance with the Europe 2020 strategy for "smart, sustainable and inclusive growth", the challenges of the environment, climate change and innovation determine more and more strongly the direction of rural development (EC, 2010). In this context the second pillar of the CAP supports knowledge transfer and innovation, increasing competitiveness, assisting food chain organisation, risk management and the sustainability of the agricultural environment and, in rural areas, increasing social acceptance, reducing poverty and promoting economic development. The priorities all contribute to achieving the overall objectives through innovation, environment and climate change reduction as well as by adaptation to all of these. In the three countries, Priority 1, which concerns knowledge transfer and innovation in agriculture, forestry and rural areas is also a horizontal priority, incorporated into the remaining five priorities (Table 7).

Table 7: Indicative public support for the RDPs, 2014-2020.

\begin{tabular}{lrrrrrr}
\hline \multirow{2}{*}{ Priority } & \multicolumn{2}{c}{ Czech Republic } & \multicolumn{2}{c}{ Slovakia } & \multicolumn{2}{c}{ Hungary } \\
\cline { 2 - 7 } & $\begin{array}{c}\text { EUR } \\
\text { million }\end{array}$ & per cent & $\begin{array}{c}\text { EUR } \\
\text { million }\end{array}$ & per cent & $\begin{array}{c}\text { EUR } \\
\text { million }\end{array}$ & per cent \\
\hline 1. Knowledge transfer and innovation & - & - & - & - & - & - \\
\hline 2. Farm viability, competitiveness & 552.1 & 18.0 & 374.3 & 18.0 & 716.0 & 17.2 \\
\hline 3. Food chain organisation & 240.0 & 7.8 & 400.4 & 19.3 & 772.0 & 18.5 \\
\hline 4. Preserving ecosystems & $1,976.7$ & 64.3 & 896.5 & 43.1 & $1,203.4$ & 28.8 \\
\hline 5. Resource efficiency & 24.2 & 0.8 & 19.2 & 0.9 & 629.2 & 15.1 \\
\hline 6. Social inclusion & 231.3 & 7.5 & 310.1 & 14.9 & 753.2 & 18.0 \\
\hline Technical assistance & 30.0 & 1.0 & 79.1 & 3.8 & 96.9 & 2.3 \\
\hline Early retirement (M113) & 20.0 & 0.7 & & & 3.4 & 0.1 \\
\hline Total & $3,074.2$ & 100.0 & $2,079.6$ & 100.0 & $4,174.0$ & 100.0 \\
\hline
\end{tabular}

Source: EC, 2015b

The Slovak Rural Development Programme (RDP), based on EP and the Council Regulation No. 1305/2013 and Commission Implementing Regulation No. 808/2014, has been allocated EUR 2.1 billion of public money for the period 2014-2020 (EUR 1545 million from the EU budget and EUR 534 million of national funding). The programme as assessed by the targets (EC, 2015b) will increase the competitiveness of agriculture and forestry by supporting investments on 1250 farms and 400 food enterprises. It will ensure appropriate management of natural resources and encourage farming 
practices which are climate-friendly. Around 20 per cent of farmland will be farmed in a manner that protects biodiversity, soil and/or water resources. The RDP aims to boost the whole rural economy by creating 2000 jobs. These new jobs will be created through investment in enterprises (including innovative cooperation projects), infrastructure, human resources via training, advisory services and local services (including integration of marginalised communities).

In the Czech Republic the RDP has a budget of EUR 3,074 million of public money for the period 2014-2020 (EUR 2.3 billion from the EU budget, including EUR 135 million transferred from the envelope for CAP direct payments, and EUR 769 million of national co-funding). The RDP focuses mainly on ensuring the sustainable management of natural resources and encouraging climate friendly farming practices, with around 25 per cent of agricultural land under contract to protect biodiversity, 11 per cent to improve water management and 12 per cent to protect soil. The second focus is to increase the competitiveness of agriculture and forestry as well as that of the food industry, aiming to provide investment support to 3500 farms, 1450 investment projects in forestry technologies and 830 projects in the food industry. The RDP will also help boost the rural economy by creating almost 1900 new jobs. The priorities will be completed by knowledge transfer and advisory services, where almost 19,000 participants will be trained and 3000 will receive specific advisory services (EC, 2015b). In addressing these challenges, the RDP will fund actions under all six Rural Development priorities - with a particular emphasis on Priority 4: Restoring, preserving and enhancing ecosystems related to agriculture and forestry.

In Hungary the RDP will use EUR 4,174 million of public funding that is available for the period 2014-2020 (EUR 3.4 billion from the EU budget and EUR 740 million of national co-funding). Hungary's RDP puts particular emphasis on actions related to restoring, preserving and enhancing ecosystems, promoting social inclusion, poverty reduction and economic development in rural areas and promoting food chain organisations and risk management in agriculture. Almost 538,000 ha of agricultural land are expected to come under management contracts supporting biodiversity, improved water management and soil management. In addition, 132,000 ha of forests will come under management contracts mainly for protecting biodiversity. Hungary's RDP will contribute to social inclusion and economic development in rural areas by bringing improved services to 68 per cent of the rural population. 2600 investment projects will receive support to increase energy efficiency in the agricultural and food processing sector. The RDP will support 5500 investment projects related to processing activities and a further 4800 to improve the competitiveness of farmers. Young farmers and short supply chains will have dedicated sub-programmes, under which 3000 young farmers and 3900 farms will receive targeted support (EC, 2015b). Hungary has put particular emphasis on innovation when selecting operations and 3.6 per cent of RDP public expenditure is earmarked for actions that foster innovation and cooperation including projects under the European Innovation Partnership for agricultural productivity and sustainability (EIP-Agri). In addressing these challenges, Hungary's RDP will fund actions under all of the six Rural Development priorities - with a particular emphasis on restoring, preserving and enhancing ecosystems related to agriculture and forestry as well as promoting social inclusion, poverty reduction and economic development in rural areas and promoting food chain organisations and risk management in agriculture.

Concerning the focus areas, expenditures by main measures are targeting Agro-environment and climate, and Payments for areas with natural and other specific constraints in the Czech Republic and Slovakia (51.4 per cent and 30.1 per cent of the public expenditures of the RDPs); Productive investments and Farm and business development in Hungary (42.0 per cent of the public expenditures of the RDP). Productive investments are also in focus in the Czech Republic and Slovakia (18.3 per cent and 26.1 per cent respectively), and Agro-environment and climate in Hungary, but all to a lower extent (15.3 per cent) (Table 8). 
Table 8: Main RDP measures in budgetary terms, 2014-2020.

\begin{tabular}{llrr}
\hline \multirow{2}{*}{ Country } & \multicolumn{1}{c}{ Measure } & $\begin{array}{c}\text { EUR } \\
\text { million }\end{array}$ & per cent \\
\hline \multirow{3}{*}{$\begin{array}{l}\text { Czech } \\
\text { Republic }\end{array}$} & M10 - Agri-Environment and climate & 905 & 29.4 \\
\cline { 2 - 4 } & M13 - Payments for areas with natural and others specific constraints & 677 & 22.0 \\
\cline { 2 - 4 } & M4 - Productive investments & 563 & 18.3 \\
\cline { 2 - 4 } & M11 - Organic Farming & 330 & 10.7 \\
\cline { 2 - 4 } & Total public expenditure & 2,475 & 80.4 \\
\cline { 2 - 4 } Slovakia & M13 - Productive investments & 542 & 26.1 \\
\cline { 2 - 4 } & M10 - Agri-Environment Climate & 483 & 23.2 \\
\cline { 2 - 4 } & M8 - Forestry & 143 & 6.9 \\
\cline { 2 - 4 } & Total public expenditure & 137 & 6.6 \\
\hline \multirow{3}{*}{ Hungary } & M4 - Productive investments & 1,305 & 62.8 \\
\cline { 2 - 4 } & M10 - Agri-Environment and climate & 638 & 34.1 \\
\cline { 2 - 4 } & M6 - Farm and business development & 328 & 15.3 \\
\cline { 2 - 4 } & M7 - Basic services in rural areas & 279 & 6.9 \\
\cline { 2 - 4 } & Total public expenditure & 2,670 & 64.0 \\
\hline
\end{tabular}

Source: EC, $2015 b$

In the Czech Republic, the competitiveness of agriculture and sustainable forestry priority of the RDP includes support to modernise 3,500 farms (13.3 per cent of the total). The aim is to improve their overall performance and competitiveness. It will also support around 420 land consolidation projects which will improve the competitiveness of the farms and reduce the risk of soil erosion. Generational renewal will be enhanced by providing start-up support to 750 young farmers. These actions will be supported by knowledge transfer activities via vocational training, information actions and integrating knowledge from research in order to provide innovative solutions to increase the sustainability and productivity of agriculture and the food industry. In order to multiply the investment effects more than 6,500 persons will be trained and 25 operational groups will be supported linked to the EIP-Agri. Almost 250 cooperation projects, including 20 projects within EIP-Agri Operational Groups, are to be supported. The competitiveness of forestry should be increased by building and/or modernising $830 \mathrm{~km}$ of forest roads and by investing in modern technologies on around 900 private forestry enterprises. The RDP aims to increase the added value of agricultural production by supporting nearly 830 operations in agricultural processing and marketing as well as supporting short supply chains and local markets. The RDP will also improve animal welfare on 1400 farms.

Slovakia is rich in natural and traditional heritage and natural resources which provide opportunities for more diversified agriculture, forestry and the rural economy (e.g. through rural tourism). The RDP 2014-2020 support will promote innovative projects delivering new products, technologies, techniques or ways of working. One main objective will be to increase the competitiveness of agriculture and forestry by supporting the investments bringing the higher added-value to the primary production and increasing the efficiency of the organisation of the supply chain. In this way, agricultural diversification with particular focus on the specialised plant (e.g. fruits and vegetables) and animal sectors should create more resilient and productive agriculture with new jobs and alternatives for agricultural diversification. 
Under this priority the RDP includes support to 1250 farms (5.1 per cent of the total) for investments in the specialised plant (i.e. excluding cereals and oilseeds) and animal sectors, while simultaneously targeting resource efficiency (water, soil, energy) and GHG emissions. The generational renewal will be enhanced by providing start-up aid support to 600 young farmers and development aid for 330 small family farms. These targets will be supported by knowledge transfer activities via vocational training, demonstration actions and research projects providing innovative solutions to increase the sustainability and productivity of agriculture. The competitiveness of the forestry sector should be increased by building and/or modernising $250 \mathrm{~km}$ of forest roads, by investing in modern technologies including processing investments in 230 forestry holdings. Around 400 food companies will receive support for investments aimed at increasing the added-value of domestic production, as well as collective investments and integrated projects aimed to promote the horizontal and vertical cooperation of food chain actors. The risk of flood damage in agriculture will be reduced by restoring and modernising $512 \mathrm{~km}$ of hydro-melioration channels which will protect 46 thousand ha of agricultural land.

Hungary will invest quite heavily in actions related to the knowledge transfer and innovation in agriculture, forestry and rural areas priority. Knowledge transfer will address the training, information actions, exchanges and farm visits, advisory services and the training of advisors. In total, 46,400 participants will benefit from training supported by the RDP 2014-2020. An important element is innovation: 470 projects will be supported to strengthen the link between agriculture, food and forestry sectors and research and innovation, 70 of which will be under the EIP-Agri. Given the ageing farmer population and the small size of agricultural holdings in Hungary, the RDP will support the start-up of 3000 young farmers and the development of 3000 small farms. The investments and modernisation of 4800 existing and competitive farms are also programmed with a clear targeting on the animal husbandry and horticultural sectors and on young farmers to increase the competitiveness of the agri sector and sustainable forestry. Hungary will support 5,500 projects targeting processing and marketing development. It aims to improve the market position of the farmers by supporting the setting up of 200 producer groups, which will bring together 4000 farmers. Hungary will also support farmers' participation in quality schemes and quality promotion activities. Hungary is also introducing risk management instruments. Insurance premiums and income stabilisation support will be provided to 15,000 farms.

In the Czech Republic, the restoring, preserving and enhancing ecosystems related to agriculture and forestry priority targets more than 1 million ha to prevent land abandonment and to promote organic farming (support to either maintain or convert 400 thousand ha to organic farming). This will maintain sustainable farming in areas with natural and other specific constraints. It will also bring benefits in terms of biodiversity and the environment. Nearly 870 thousand ha of farmland will be subject to voluntary agro-environmental and climate-related commitments by farmers, who will receive training and advice so that they can better deliver environmental and climate-related benefits. Preventive and restorative actions will increase the resilience of forests in the face of natural disasters. Resource efficiency and climate priority will support renewable energy investments to process agricultural waste (e.g. supporting the construction of biogas plants to process manure). It will also support the afforestation of 1,000 ha of agricultural land in order to increase $\mathrm{CO}_{2}$ sequestration.

In Slovakia the second main objective will be the protection and maintenance of high nature value agricultural and forestry areas, targeting the sustainable use of soils and water, and thus providing more opportunities for high quality food production and creation of rural tourism activities including diversifying products and services outside agriculture towards a variety of economic activities in rural areas. Restoring, preserving and enhancing ecosystems related to agriculture and forestry will prevent land abandonment (1.2 million ha targeted) and promote organic farming practices (150,000 ha will be supported), maintaining the farming activity in areas with natural and other 
specific constraints to farming. Nearly 250,000 ha of agricultural land will be under voluntary agroenvironmental and climate-related commitments by farmers, who will also use related training and advisory services to better deliver the environmental and climate-related benefits. The resilience of forests against natural disasters will be increased by preventive and restoration actions against fire, biotic diseases and floods. Resource efficiency and climate priority will focus on the use of renewable energy resources, mainly by processing the waste and biomass production from agro-food sector and forestry. Additional impacts on resource efficiency and climate are expected to result from the investment projects supported under other priorities.

In Hungary the RDP has a strong focus on energy efficiency related investments in the agriculture and food processing sectors and aims to support 2600 projects. The efficiency of existing water management systems will be improved on 6000 ha of agricultural land. Under the climate change mitigation priority, the RDP will pursue carbon sequestration mainly by supporting afforestation, agroforestry systems, the prevention and restoration of damage to forests, the improvement of the resilience and environmental value of forest ecosystems, as well as their conservation, also by encouraging environmentally and climate friendly forest conservation services. The RDP will also pursue the reduction of greenhouse gas and ammonia emissions by investments in manure storage. Under the restoring, preserving and enhancing ecosystems related to agriculture and forestry priority, Hungary will target interventions on territories with inland water and drought problems and on high nature values areas. Around 11.5 per cent of agricultural land and 6.4 per cent of forests will be under management contracts for supporting biodiversity, to improve water and soil management. Around 26 per cent of the allocated EAFRD funds will be used for area-based payments to farmers for using environment/climate-friendly land management practices, including organic farming, support to areas facing natural constraints and support to areas under Natura 2000 management. Over 111 thousand hectares of farmland will receive support to either convert or maintain organic farming.

In the framework of social inclusion and local development priority the Czech RDP aims to create 1100 jobs through operations focused on investments in non-agricultural activities and agro-tourism. It will support 160 LAGs and create 750 jobs. Actions under this priority will be complemented by other ESI Funds interventions in the context of multi-funds Community Led Local Development initiatives. In addition, the RDP will improve the economic and social conditions of rural citizens through investments in infrastructure, including broadband Internet. The LEADER approach should also help in the more efficient use of local resources and to enhance the ownership of investments and cooperation of local actors in integrating economic activities for creating new jobs and improving the quality of life. In Slovakia, investments in diversification of the rural economy beyond agriculture should create 1100 jobs through the implementation of local development strategies and an additional 900 jobs in micro and small enterprises. The broadband infrastructure investments in small municipalities should provide high-speed Internet for rural citizens and local enterprises with affordable prices. Specific actions will promote the social integration of marginalised communities. In Hungary, in operations programmed under the social inclusion and local development priority, 4500 additional jobs will be created and 68 per cent of the rural population will benefit from improved services. The Hungarian RDP will support the diversification of farmers' activities and improve access to local services. It will also support basic service development in small and very small villages by waste water treatment in villages with fewer than 2000 inhabitants and with the establishment of multifunctional community spaces in villages with fewer than 1000 inhabitants. LDSs will be implemented through LEADER LAGs and will cover over 68 per cent of the rural population. 


\section{Conclusions}

Slovakia focused mainly on multifunctional agricultural and forestry systems with a positive impact on the environment, and appearance of the land and nature through implementation of the measures adopted in the RDP SR 2007-2013. Another objective of the support was the competitiveness in the agricultural and forestry sectors in connection with innovation, restructuring, modernisation, education and advising. Activities aimed at diversification toward non-agricultural activities, renovation and development of municipalities and development of tourism contributed to increasing the opportunities in the rural areas.

The new RDP SR 2014-2020 follows the aims of the previous programme with filling the objectives of the rural development policy through the implementation of the diverse measures focusing in particular on: the promotion of the agricultural and forestry holdings through investments in physical assets, business support and investments in forest technologies, including preventive measures for agricultural land and forests. The programme support is dominantly focused on creating jobs, increasing competitiveness and promoting livestock and specialised crop production.

The Czech Republic used the offered possibilities to solve many issues of agriculture and rural development. The priorities were aimed at four areas: support of competitiveness of the Czech agriculture and forestry, mitigation of environmental impacts of agricultural activities, improving of quality of rural life and encouragement of local activities.

The ex-ante analysis of the new Rural Development Programme pointed out the vastness of rural issues, the amount and severity of needs which are highly desirable to be supported from public sources. However, the experience of the implementation of earlier programmes shows that the RDP cannot cover all the needs of rural areas on its limited budget, neither in terms of their spectrum nor in terms of their scope. The rural support strategy will therefore be based on an assessment focusing on those needs that the instruments of the CAP can solve more efficiently. Agriculture, forestry and food production is one of the main RDP priorities where support will be channelled, in particular with a view to increasing the competitiveness of these sectors. Analyses also indicate the lagging of the Czech Republic in a number of indicators and although previous programmes recorded significant progress, further support for the competitiveness of agriculture and the food sector is highly desirable.

The greatest emphasis in the RDP will be placed on addressing environmental concerns. Focusing primarily on this area stems from the fact that the needs identified in the analysis are significant in their impact and influence throughout the country. The issue of preserving biodiversity, preventing soil and water degradation, are climate change are ones that cannot be resolved through the market functioning of agricultural production, forestry and food processing. Moreover, environmental protection is a society-wide public interest.

In Hungary the rather modest result of the earlier rural development programmes is that over the last ten years their application contributed to reduce out-migration from rural areas. The rural development subsidies created opportunities for developing the rural economy, environment and society, assisted in preserving environmental values, induced community initiatives and mobilised the rural society. The main shortcoming of the programmes is that instead of encouraging sustainable developments to be implemented by creative ideas the programmes, they only relieved the symptoms. In rural areas the developments were determined by social constraints and basic infrastructural needs rather than by the need for economic development. A further lesson is that investments in this sector are basically encouraged by the market and rural development by itself is not able to stop the unfavourable regional processes and the lagging behind of the disadvantaged areas. In order to develop such areas and the agricultural economy suffering from competitive disadvantages, a great number of fields can be identified, the equal treatment of which might simultaneously remedy the problems of both the sector and rural areas. 
The challenge of rural development in the present programming period (2014-2020) is to achieve a simultaneous increase in value added and in job creation, as well as to enhance the development of human resources. Enterprise and economy development based on innovative ideas and projects are required as well as cooperation in the implementation. In the RDP 2014-2020 the primary means of job creation is the support provided for labour intensive sectors, livestock farming, horticulture, fruit and vegetable production, food processing as well as enhanced support for forestry. The achievement of the objective of job creation is ensured by the fact that numerous interventions of the RDP require as a condition of eligibility to maintain the number of employees and the expansion of employment is preferred in the evaluation. Regarding the priority sectors, in the cases of investment subsidies for horticulture the basic objective is to improve resource efficiency, to use geothermic energy as well as to encourage post-harvest activities either through joint investments. Employment and resource efficiency in the development of the livestock sector are also priority objectives. As for the latter, the developments focus on the energetic upgrading of the existing buildings, modernisation of the building technologies as well as on the development of the old technologies. In addition, investments supporting the reduction of greenhouse gas emissions are supported. Investment resources for arable crop production can be spent in a more targeted way than in the NHRDP (such as water retention, melioration, modernisation of irrigation, development of small grain silos and dryers, upgrading equipment as well as technology developments aiming at improving resource efficiency). In order to optimise the management of water resources the RDP will provide subsidies for water retention and melioration as well as for improvement and development of the irrigation systems by putting a great emphasis on supporting joint investments. 


\title{
Agricultural land ownership, land market and land rent market
}

\author{
BIRÓ, Szabolcs¹, BUDAY, Štefan², GRAUSOVÁ, Gabriela 2 , TÓTH, Orsolya1, \\ ČIČOVÁ, Tatiana ${ }^{2}$ and VILHELM, Václav ${ }^{3}$
}

\section{Introduction}

Land as a basic resource of agricultural production has a significant economic, social and also political role. The importance and relationships between these tasks in the long term with respect to farm structure, ownership and use of land are often significantly modified. In the field of farm structures, land ownership and land use Slovakia, the Czech Republic and Hungary in many respects have similar features. The concentration of land use has a historical background, while privatisation has led to fragmented land ownership and separation of land use to a large extent. Land prices and land rent are also low. The purpose of this comparative study is to explore the common trends in land use and land market processes to identify the setbacks and search for common solutions. Another objective of the research is the analysis of market prices and rental fee development of agricultural land, and the differences in regulation of land transactions to identify development paths of structural change. The research starts from the analysis of the historical background of land use before the EU accession, describes the current situation in the farm structure and land use patterns and the status and development of the agricultural land markets to indicate the possibilities of common solutions for further development.

\section{Historical background}

Agriculture underwent considerable changes in the second half of the $20^{\text {th }}$ century that affected land use in the three countries. Under the communist regime the traditional structure based on the existence of family farms was gradually liquidated. Agricultural production was organised into largescale collective and state farms based mainly on a central planning mechanism. The key process was collectivisation, which resulted in large scale management systems with efforts to increase productivity with the economy of scale and modernisation of agricultural equipment.

In the Czech Republic in 1989 more than two-thirds of the area of agricultural land was utilised by agricultural cooperatives, less than 30 per cent by state farms and only less than 4 per cent of agricultural land was farmed by private peasants. In Hungary, the pre-transition farm structure was characterised by a dominance of collective and state farms also. In 19893.8 per cent of farmed land ownership belonged to state farms, 61.1 per cent to collective farms and nearly one third of farmed land ownership to collective farm members. On the other hand, in the case of land use there were 136 state farms with an average size of 6886 hectares. In Hungarian collective farms (1245 collective farms with average area 4180 hectares) production assets and three-fifths of the collective farm land were in collective ownership, while another one-third of the land was privately owned by the members. Household plots were cultivated by members of collective farms or state farm workers. Together with other private farmers their number was estimated 1.4 million in 1989 with an average farm size of 0.6 hectares. The 'symbiosis' between large-scale farms and household plots led to the relative success of Hungarian agriculture under the former regime (Mathijs and Mészáros, 1997).

In Slovakia in 1989, co-operatives accounted for a 64 per cent share of total agricultural output, with state farms (public sector) accounting for 21 per cent and family farms and household plots 15 per cent. These figures may better express the importance of private agricultural production under the former system than data on farmed land only, especially since household farms often specialised in livestock

Research Institute of Agricultural Economics, Budapest, Hungary.

National Agricultural and Food Centre - Research Institute of Agricultural and Food Economics, Bratislava, Slovak Republic.

Institute of Agricultural Economics and Information, Prague, Czech Republic. 
and other high value added produce (e.g. greenhouse vegetables). The process of transformation to a market economy started in 1990, and this again significantly affected the agriculture and business in this sector. In the 1990s the transformation of agricultural cooperatives and privatisation of state farms took place and other private farmers started to manage independently. Some of the new agricultural cooperatives were further transformed into joint-stock companies or limited liability companies.

In Slovakia, agricultural cooperatives have been transformed into cooperatives shareholders. State farms also lost their role in production, losing the business structure of agricultural farms (the number of state farms in 1990 reached 73 with an average area of 5,083 hectares of agricultural land, currently managed five state owned enterprises on agricultural land with an average area 1441 ha (HCSO, 2011). As the results of transformation to a market economy in Slovakia, commercial companies use 40.8 per cent of agricultural land, agricultural cooperatives cultivate 39.0 per cent, while natural persons and farmers manage only 16.7 per cent. In the Czech Republic half of agricultural land is managed by companies, 20.1 per cent is used by cooperatives, and 29.9 per cent by individual farms. In Hungary the changes were the most considerable in land use, where 59.3 per cent is cultivated by private farms, while the rest is used by economic organisations.

\section{Farm structure}

In all the three countries land use is concentrated and characterised by a bipolar farm structure. Most of the utilised agricultural area in Slovakia (76.7 per cent), in the Czech Republic (69.4 per cent) and in Hungary (36.1 per cent) is cultivated by the few large farms $(1.5 ; 3.9$ and 0.2 per cent respectively) (Table 1). This pattern of land use strongly limits the development capability of the middle size farm group (50 to 500 hectares).

Table 1: Farm structure by main size groups, 2013.

\begin{tabular}{|c|c|c|c|c|}
\hline \multirow{2}{*}{ Size group (UAA ha) } & \multicolumn{2}{|c|}{ Number of farms } & \multicolumn{2}{|c|}{ Utilised agricultural area } \\
\hline & thousand & per cent & thousand ha & per cent \\
\hline \multicolumn{5}{|c|}{ Slovakiaa) $^{\text {a) }}$} \\
\hline under 10 & 60.7 & 91.3 & 65.7 & 3.4 \\
\hline 10 to 50 & 2.9 & 4.4 & 67.8 & 3.5 \\
\hline 50 to 500 & 1.9 & 2.9 & 318.5 & 16.4 \\
\hline 500 to 1000 & 0.4 & 0.6 & 318.9 & 16.5 \\
\hline 1000 and more & 0.6 & 0.9 & $1,165.7$ & 60.2 \\
\hline Total & 66.5 & 100.0 & $1,936.6$ & 100.0 \\
\hline \multicolumn{5}{|c|}{ Czech Republic } \\
\hline under 10 & 29.9 & 64.6 & 77.8 & 2.2 \\
\hline 10 to 50 & 9.3 & 20.2 & 211.8 & 6.0 \\
\hline 50 to 500 & 5.3 & 11.4 & 789.8 & 22.4 \\
\hline 500 to 1000 & 0.8 & 1.8 & 603.6 & 17.1 \\
\hline 1000 and more & 1.0 & 2.1 & $1,848.1$ & 52.3 \\
\hline Total & 46.2 & 100.0 & $3,531.1$ & 100.0 \\
\hline \multicolumn{5}{|c|}{ Hungary } \\
\hline under 10 & 402.7 & 88.9 & 427.9 & 9.3 \\
\hline 10 to 50 & 36.0 & 7.9 & 769.7 & 16.8 \\
\hline 50 to 500 & 13.0 & 2.9 & $1,735.6$ & 37.8 \\
\hline 500 to 1000 & 0.6 & 0.1 & 447.8 & 9.8 \\
\hline 1000 and more & 0.6 & 0.1 & $1,208.4$ & 26.3 \\
\hline Total & 452.9 & 100.0 & $4,589.4$ & 100.0 \\
\hline
\end{tabular}

a) In the case of Slovakia 2007

Source: Eurostat 
The land use shares of family size farms are relatively small. In Slovakia, 7.3 per cent of all farms belong to the 10 to 500 hectares' size group, compared to 31.6 per cent in the Czech Republic and 10.8 per cent in Hungary, while their land use expands only to 19.9 per cent; 28.4 per cent and 54.6 per cent respectively. The small farms (under 10 hectares) constitute the third branch of land use and are the most numerous size group: 91.3 per cent of all farms in Slovakia, 64.6 per cent in the Czech Republic, and 88.9 per cent in Hungary, but cultivating the smallest shares of agricultural land (3.4 per cent; 2.2 per cent and 9.3 per cent).

Farm structure development in all three countries is also characterised by the progress of concentration, which covers two, slightly contradictory, processes: the declining number of private farms and the growing number of legal entities. In Slovakia there was a gradual ( 70 per cent) decrease in the number of private farms larger than 1 hectare, although their average cultivated agricultural area grew (4.2 times) to 16.5 hectares between 2001 and 2013. In this period the number of legal entities grew by 67.8 per cent to 2746 , while the average cultivated agricultural area decreased by 42 per cent to 671.8 hectares. Cooperatives (38.8 per cent) and limited liability companies ( 35.6 per cent) are the main user groups of the total agricultural land (Table 2).

\section{Table 2: Development of farm structure by legal form in Slovakia,} the Czech Republic and Hungary, 2000-2013.

\begin{tabular}{|c|c|c|c|c|c|c|}
\hline \multirow[t]{2}{*}{ Legal form } & \multicolumn{2}{|c|}{ Number of farms } & \multicolumn{2}{|c|}{$\begin{array}{l}\text { Utilised agricultural } \\
\text { area } \\
\text { (thousand hectares) }\end{array}$} & \multicolumn{2}{|c|}{$\begin{array}{l}\text { Average area } \\
\text { (hectares) }\end{array}$} \\
\hline & 2000 & 2013 & 2000 & 2013 & 2000 & 2013 \\
\hline \multicolumn{7}{|c|}{ Slovakia } \\
\hline Natural persons total & 69,402 & 20,820 & 269.8 & 368.9 & 3.9 & 16.5 \\
\hline of which reg. agric. entrepreneurs & 5,874 & 5,389 & 222.2 & 310.2 & 37.8 & 52.7 \\
\hline Legal persons total & 1,636 & 2,746 & $1,889.5$ & $1,532.7$ & $1,154.9$ & 671.8 \\
\hline of which commercial companies & 825 & 1,970 & 723.5 & 816.6 & 876.9 & 414.5 \\
\hline limited liability companies & 700 & 1,833 & 549.9 & 677.0 & 785.6 & 487.4 \\
\hline joint stock companies & 123 & 131 & 173.1 & 139.2 & $1,407.7$ & $1,087.7$ \\
\hline cooperatives & 722 & 567 & $1,131.4$ & 700.1 & $1,567.1$ & $1,198.8$ \\
\hline Together & 71,038 & 23,566 & $2,159.3$ & $1,901.6$ & 30.4 & 77.7 \\
\hline \multicolumn{7}{|c|}{ Czech Republic } \\
\hline Natural persons total & 24,053 & 22,844 & 934.1 & $1,049.9$ & 38.8 & 46.0 \\
\hline of which reg. agric. entrepreneurs & 20,115 & 17,936 & 849.3 & 982.5 & 42.2 & 54.8 \\
\hline Legal persons total & 2,587 & 3,431 & $2,680.7$ & $2,458.2$ & $1,036.2$ & 716.5 \\
\hline of which commercial companies & 1,726 & 2,751 & $1,578.9$ & $1,725.0$ & 914.8 & 627.0 \\
\hline limited liability companies & 1,171 & 2,079 & 783.7 & 830.4 & 669.3 & 399.4 \\
\hline joint stock companies & 519 & 637 & 779.7 & 877.1 & $1,502.3$ & $1,377.0$ \\
\hline cooperatives & 723 & 513 & $1,059.4$ & 704.0 & $1,465.3$ & $1,372.4$ \\
\hline Together & 26,640 & 26,275 & $3,614.8$ & $3,508.1$ & 135.7 & 133.52 \\
\hline \multicolumn{7}{|c|}{ Hungary } \\
\hline Natural persons total & 86,400 & 69,860 & $1,756.8$ & $2,220.8$ & 20.3 & 31.8 \\
\hline of which reg. agric. entrepreneurs & - & 12,909 & - & 292.6 & - & 22.7 \\
\hline Legal persons total & 3,872 & 5,901 & $2,350.4$ & $2,119.7$ & 607.0 & 359.2 \\
\hline of which commercial companies & 3,550 & 5,088 & $2,271.1$ & $2,007.3$ & 639.7 & 394.5 \\
\hline limited liability companies & 1,667 & 3,674 & 689.0 & $1,145.7$ & 413.3 & 311.8 \\
\hline joint stock companies & 224 & 308 & 460.0 & 542.6 & $2,053.7$ & $1,761.9$ \\
\hline cooperatives & 939 & 387 & $1,045.6$ & 232.3 & $1,113.5$ & 600.3 \\
\hline Together & 90,272 & 75,761 & $4,107.2$ & $4,340.5$ & 45.5 & 57.3 \\
\hline
\end{tabular}

Remark: Farm size more than 1 ha in Slovakia, more than 3 ha in The Czech Republic and 5 ha in Hungary.

Source: Eurostat 
In the Czech Republic the number of private farms (22.8 thousand) operating more than 3 hectares did not change considerably between 2000 and 2013. Their average agricultural area grew by 18.3 per cent. The number of legal persons grew by 32.6 per cent, while their average agricultural area fell by 30.9 per cent to 716.5 hectares. The main land user group by legal form is the registered natural persons (28.0 per cent), while the share of joint stock ( 25.0 per cent), the limited liability companies (23.7 per cent) and the cooperatives (20.1 per cent) are almost equal.

In Hungary the number of private farms with more than 5 hectares of farmed agricultural land (69.9 thousand) declined by 19.1 per cent in the monitored period. By 2013 their average agricultural area reached 31.8 hectares, which is a 56.1 per cent growth over 2000. The number of legal entities raised by 52.4 per cent to 5.9 thousand, while their average agricultural area decreased by 40.8 per cent to 394.5 hectares. The main land user groups are the natural persons (51.2 per cent), Limited liability (26.4 per cent) and Joint stock companies (12.5 per cent).

There is a strong correlation between the prevalence of land rental at the country level and the proportion of corporate farms in total land use. While corporate farms own little land, they operate on a high proportion of UAA, almost all of which is rented. Of the total agricultural land area, 80.6 per cent in Slovakia, 70.1 per cent in the Czech Republic and 48.9 per cent in Hungary was used by corporate farms in 2013.

These corporate farms continue to use large proportions of the land for a variety of reasons. A major underlying factor is that historically the large-scale farms have been the primary users of the land. New landowners may face significant transaction costs if they want to withdraw their land from the farms and reallocate it (Swinnen and Vranken, 2009). In all the three countries the development of the land rental market plays a key role in flexible land allocation to efficient agricultural production.

\section{Land ownership and use}

In the three countries, agricultural land is mainly private property. In Hungary more than 85 per cent of the 5.6 million hectares of total agricultural land were owned by natural persons and 11.3 per cent was state property in 2014. The ownership share of cooperatives and economic organisations is just 2.9 per cent. In Hungary, based on the HCSO (2014) land tenancy is 67.3 per cent (Figure 1). The operation of larger farms is based almost exclusively on rented land. Land ownership is fragmented and scattered. In rural areas 2.8 million units - of only 3 hectares on average - are registered. The average size of units owned by natural persons is 2.7 hectares, while the average size of the land that is state property is 7.9 hectares. In order to stop the decline in the sizes of the units (between 2000 and 2014 it was 10 per cent), measures for land consolidation and for preventing further fragmentation the introduction of regulations on agricultural inheritance are required.

In Slovakia, 75 per cent of agricultural land is owned by private persons. In the restitution process, governed by Act No. 229/1991 Coll, 43.9 thousand decisions were adopted by 31 December 2013 to grant the ownership of 209 thousand hectares of land. In Slovakia 7 per cent of the UAA is state-owned, while the owners of 438 thousand hectares were not known. Unknown ownership is also managed by the land fund and might be subject to restitution or privatisation. The major disintegration of the land and the high number of owners hinder the development of the land market. In Slovakia few owners use the land for their own business purposes, the majority rent it out. On average almost 90 per cent of agricultural subjects operate on leased land. In the Czech Republic, land ownership is also still characterised as very fragmented. The share of rented land in agriculture is 74 per cent, but with a decreasing trend in the last ten years. 
Figure 1: Share of rented land in total UAA in Slovakia, the Czech Republic and Hungary, 2003-2013.

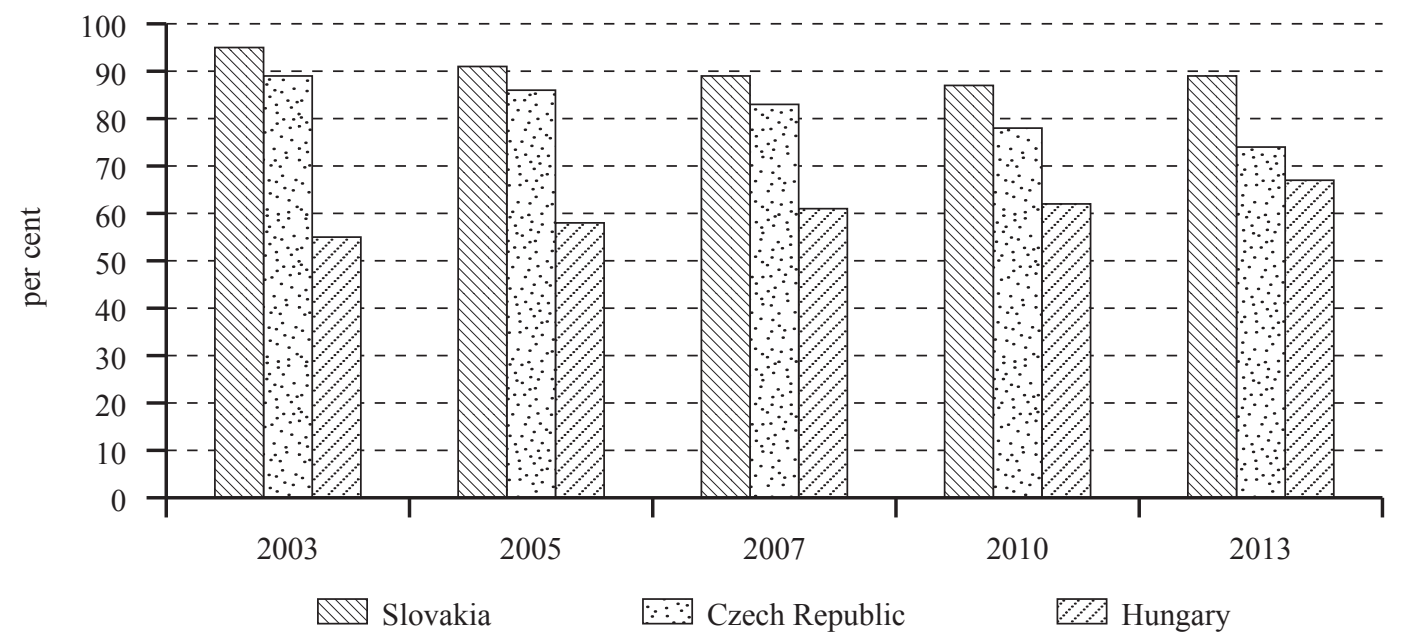

Source: Eurostat

Land consolidation is a long-term measure for increasing agricultural production efficiency. Land consolidation in the Czech Republic, Slovakia and Hungary focus more on addressing the fragmentation of land ownership issues than structure of land use (Hartvigsen, 2015). In Act No. 122 of 2013 Coll (New Land Act), Hungary uses regulative elements such as pre-emption right of the local neighbouring farms for eliminating the negative effects of high unit transaction costs of small parcels. Beyond domestic and foreign investors, private investment funds could also participate in structural change through the accumulation of capital for land consolidation and land banking activities.

Despite privatisation, a considerable amount of agricultural land still remained in the ownership of the State, managed by national land funds. In Hungary, privatisation of the state land fund started in 2015 with 380 thousand hectares of agricultural land out of the 2 million hectares of productive area in the property of the Hungarian State. A considerable part of the area sold was under lease agreements. The sale of state agricultural land in the Czech Republic is almost completed: more than 500 thousand hectares of state land have been privatised. Not surprisingly, this sale of state agricultural land has had a substantial impact on the average land sales price as the administrative prices which are used for privatisation were considerably lower than the market prices. Owing to the increased supply of land for sale, the latter prices have fallen in the last few years. Under the control of the state, around 360 thousand hectares, 20 per cent of UAA remains in administration of the Slovak Land Fund. This fact affects the agricultural land market and also the amount of paid rent. Problems persist, especially the high percentage of agricultural land under state administration, the fragmentation of agricultural land, problems with setting the price of agricultural land and the different regional policies on taxes for agricultural land.

\section{Agricultural land market}

In Slovakia, the Czech Republic and Hungary, the highly fragmented land ownership is a significant common feature that obstructs land market development. The largest differences among the three countries in the development paths of land market exists in regulations. In Hungary land acquisition opportunities of legal entities are prohibited and ownership and tenancy have size limits while in Slovakia and in the Czech Republic the land market is relatively free: legal entities can buy land on the market and size limits do not apply. 


\section{Regulations}

In Slovakia the acquisition of agricultural property is regulated by the Act No. 140/2014 Coll. The purpose of the Act is to create a legal environment that will allow agricultural land to continue to serve its purpose. The Act favours land purchase by persons who have performed agricultural production as a business for at least three years in the municipality where the agricultural land is located, or in the neighbouring municipality. If such persons are not interested in the transfer of agricultural land, the authorised person is also the person who has performed agricultural production as a business for at least three years regardless of the place of business. The Act does not apply to all agricultural land. Gardens, agricultural land in urban zone and small areas of land (up to $0.2 \mathrm{ha}$ ) located outside the urban zone are excluded from its scope.

In Slovakia, before 1 May 2014 there were restrictions on the ownership of agricultural land by foreigners, defined as a natural person with no permanent residence in Slovakia or a legal person not established in Slovakia (Act No. 312/2004 Col.). At the same time, there were some specific exceptions and some practical limitations. Firstly, foreigners with a residence permit in Slovakia who had rented and farmed the land for at least three years after Slovakia's accession to the EU can buy and own land in Slovakia. In such cases, a rental contract between the landowner and the tenant (foreign individual) duly signed by both parties was necessary. In addition, foreigners could acquire agricultural land through inheritance and by exercising pre-emptive rights in the case of co-ownership (Civil Code No. 40/1964 Col.). On the other hand, foreigners from non-EU member states cannot own agricultural land in Slovakia. Furthermore, foreigners could establish legal entities (a joint stock company or a limited liability company) registered in Slovakia and buy land through that legal entity. According to Act No. 513/1991 Col., the procedure and requirements for setting up a legal entity in Slovakia are the same for Slovak and foreign individuals. A legal entity registered in Slovakia and owning land in Slovakia can later sell that land without any restrictions to a company registered in another country (Act No. 220/2004 Coll.).

The tenancy of agricultural land in Slovakia is regulated by Act No. 504/2003 Coll.. The agreement on the amount of rent or method of its regulation is required for the formation of a contract for rent of land for agricultural purposes. The amount of rent is at least one percent of the official price of agricultural land.

In the Czech Republic, the private land market has no ownership restriction now. Only the sales of state land were restricted to natural persons until November 2010, when the Czech government eased the eligibility conditions for foreigners who wanted to buy state land. Pre-emptive right for purchases of state land is given to the following persons: farmers, landowners, partners in corporate farms, members of cooperatives and eligible persons from restitutions (Ciaian et al., 2012). Foreign natural persons and legal entities could not acquire agricultural land until 2011 (Act No. 219/1995 Coll.). There were some exceptions, however. Firstly, foreigners could acquire land if they have Czech citizenship or if they were married to a Czech person. In addition, foreigners could acquire land through inheritance or if they exercise pre-emptive rights that emerge from co-ownership. They could also acquire land if the land cannot be separated from another asset that is already owned by the foreigner or in exchange for domestic land. EU-citizen farmers could also acquire agricultural land if they are registered as selfemployed farmers and if they have been resident in the Czech Republic for at least three years. This means that natural persons residing and farming for at least three years in the Czech Republic on rented land, as well as Czech legal entities combining Czech and foreign capital, were eligible to buy private agricultural land. The farmers had to prove their integrity, professional knowledge in farming and also knowledge of the Czech language (Act No. 252/1997 Coll.). No other special procedures or conditions were required for eligibility, except to be officially registered as a farmer or a Czech company and to use the purchased land in a 'proper way' according to the Land Protection Law (Act No. 334/1992 Coll.). There were also no limits to the amount of land that can be bought by eligible foreigners. 
In the Czech Republic until the mid-2012, the rent for agricultural land was regulated by Act No. 299/1991 Coll., where the rent was set at one percent of the official price of agricultural land unless the tenant with the landlord agree otherwise. Since mid-2012, this provision applies only to stateowned land and since October 2013 this provision was cancelled for state-owned land as well. In most cases, the tenancy relationships and the resulting rent are mutually accepted. In recent years there have been cases (in terms of tens) where a demand for a rent increase has not been accepted and some disputes have been taken to court.

From 1 May 2014, Hungary, owing to its EU membership, had to lift the bans and restrictions on land acquisition that treating Hungarian nationals EU and those from other Member States differently. The termination of the land moratorium means that from this date farmers of other EU Member States can also purchase land in Hungary with the same conditions of domestic farmers in accordance with the corresponding legislation. The aims of the legislator with the introduction of the New Land Act were also to strengthen small and medium-size family farms, to consolidate the properties by the pre-emption rights, to limit speculative land purchases and use, as well as to assist the transformation and development of the rural economy with the involvement of local communities.

The acquisition and use of agricultural land is regulated by the New Land Act. In principle, ownership of agricultural land may be acquired by Hungarian and Member State citizens registered at the land office as farmer engaged in agriculture and forestry activity in his/her own name and at his/her own risk as the main occupation or part time, and with at least a secondary agricultural or forestry qualification or certification of own agricultural or forestry activity for at least three consecutive years in Hungary. Regarding the acquisition of property rights of land, normally only registered farmers can purchase land and even then not more than 300 hectares per the farmer and their family members. National and foreign legal entities are excluded from the land market. The total area of land used by natural persons qualified as farmers and by agricultural production organisations may not exceed 1200 hectares (tenancy maximum). For livestock farming or seed production the preferential tenancy maximum is 1800 hectares entitling to use the land of a member of the agricultural cooperative. Larger farms should release excess land by the time of the termination of the leasing contract.

In the New Land Act, pre-emption rights are provided for the Hungarian state, the farmer using the land, the neighbouring farmers, local farmers and farmers living within a distance of $20 \mathrm{~km}$. The pre-emption right assists the land acquisition of persons registered for farming. Land purchases by family farms and young farmers and new entrants are preferred. The new regulation implies great administrative loads and applies strong state control on the land market; for land property acquisition the approval of the agricultural administrative authority is required which has to be supported by the local land commission. The authorities control the land acquisitions and impose sanctions in the case of violations of laws.

\section{Market development}

Low land prices supplemented with high transaction costs have resulted from fragmentation and co-ownership of parcels, hindering land owners' willingness to sell their property. Inheritance leads to further fragmentation and co-ownership. Plots usually pass to all legitimate heirs, and not only to those who farmed them In the Czech Republic and in Slovakia, it is not possible to identify accurately a great number of land owners or the location of their land parcels. In Hungary, co-ownership of land exists for around 1 million hectares, hindering land transactions with considerable costs. The evaluation process of land market development in all the three countries is hindered by lack of transparency in transactions on agricultural land and rental market and, complicated by the absence of proper statistical surveys and functional information networks. Access to up to date specific issues on processed ownership and land tenure data based on land sales and rental contracts is not always possible, despite the fact that the cadastres are operating as public institutions. 
In Slovakia the Research Institute of Agricultural and Food Economics has monitored development of land market and prices in six districts since 2001 and in twelve districts of Slovakia since 2007. The analysis shows that the largest area of agricultural land, 10.3 thousand hectares, was sold in 2010. The land market was less active in 2008 with sales of 3.0 thousand hectares. The best-selling type of land was arable land. The largest share of arable land in the monitored districts was sold in 2012 (1.68 per cent). The land market price, on average EUR 1260 per hectare in 2014, forms on the open land market under the pressure of supply and demand, while relatioshipns between prices in one market are differentiated according to quality of the land (Figure 2).

Figure 2: Average agricultural land price development in Slovakia, the Czech Republic and Hungary, 2004-2014.

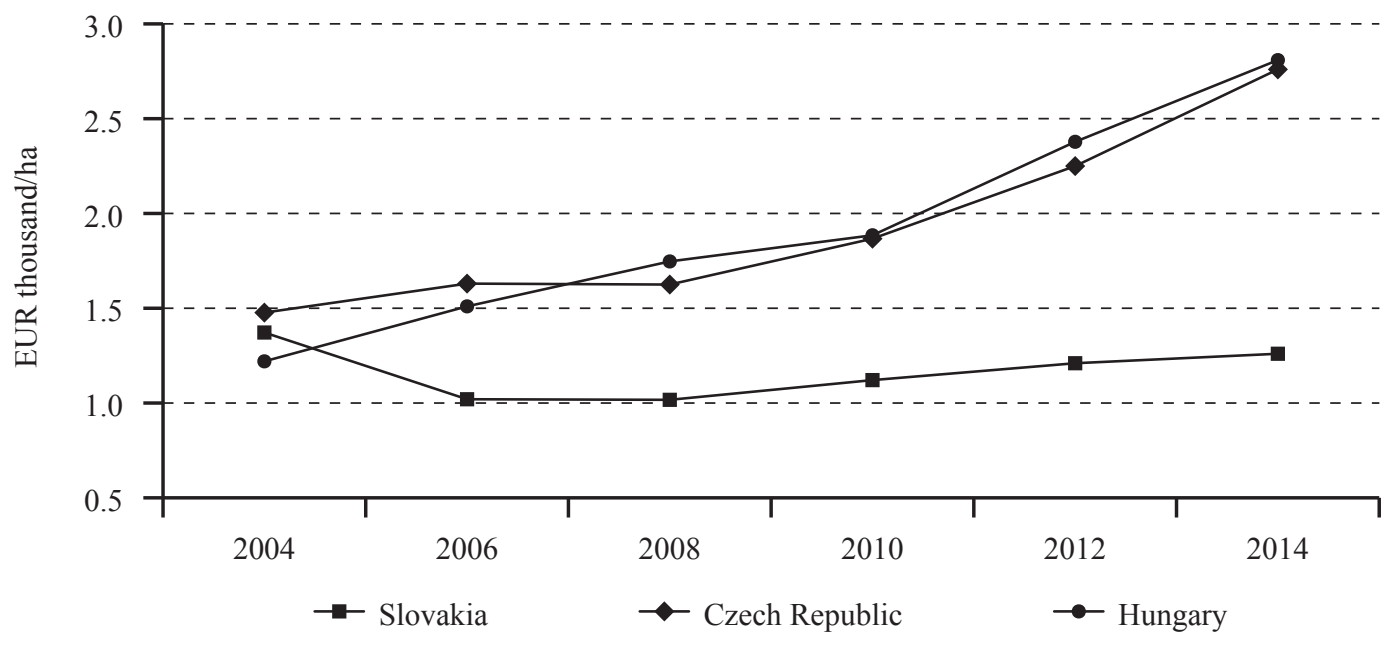

Source: Eurostat, VUZE, VUEPP, HCSO, FADN

Fragmentation of land ownership significantly limits the market. In terms of buying agricultural land for agricultural use, an interested person faces difficulties. Rent contracts concluded for at least five years also burden owners, who have to notify their tenants of cancellation of the contract one year in advance. Another factor limiting the land market is high transaction costs. Development of the average market price of agricultural land in the selected districts of Slovakia in 2007-2012 showed a variable trend and within each district it was very different. Price development of the monitored district should be carefully evaluated since sale of plots for other development purposes (e.g. real property) are also included in the database. The highest average market price for all monitored districts was in 2008 and reached EUR 27,600 per hectare ${ }^{4}$ and the lowest average market price for all monitored districts was in 2012 and reached EUR 6000 per hectare. The average land rental fee in Slovakia was EUR 44.5 per hectare in 2014, tripled from 2004 (Figure 3). The highest increase in monitored regions was recorded in the Trnava region, while in 2008 the amount of rent was EUR 42.7.per hectare, raised to EUR 73.2 per hectare in 2012. The lowest average amount of rent in 2012 was in Žilina and Prešov regions EUR 17.9 and EUR 18.8 per hectare respectively.

In the Czech Republic, the agricultural land market was until recently on the supply side dominated by the state, which since 2000 offered, according to Act No. 95/1999 Coll., the Land Fund of the Czech Republic, land for privatisation through the agency of the Land Fund of the Czech state. Because this process is now almost complete, private entities have become the dominant players in

\footnotetext{
4 A fundamental problem in monitoring the prices of agricultural land represents the distinguishing between the transfers of agricultural land with the intention of further agricultural use and of its future non-agricultural use.
} 
the Czech agricultural land market. On 1 January 2013 the State Land Office was established pursuant to Act No. 503/2012 Coll., thereby completing the transformation of the Land Fund, which was cancelled and its residual agendas were connected with the activities of the former land offices. Farmers who buy farmland most often are motivated by stabilising or expanding their own business through the purchase of agricultural land which they have only leased or additional land or an interest in entering into farming. Sometimes companies buy agricultural farmland as an investment, without farming themselves.

\section{Figure 3: Average rental fee development of agricultural land in Slovakia, the Czech Republic and Hungary, 2004-2014.}

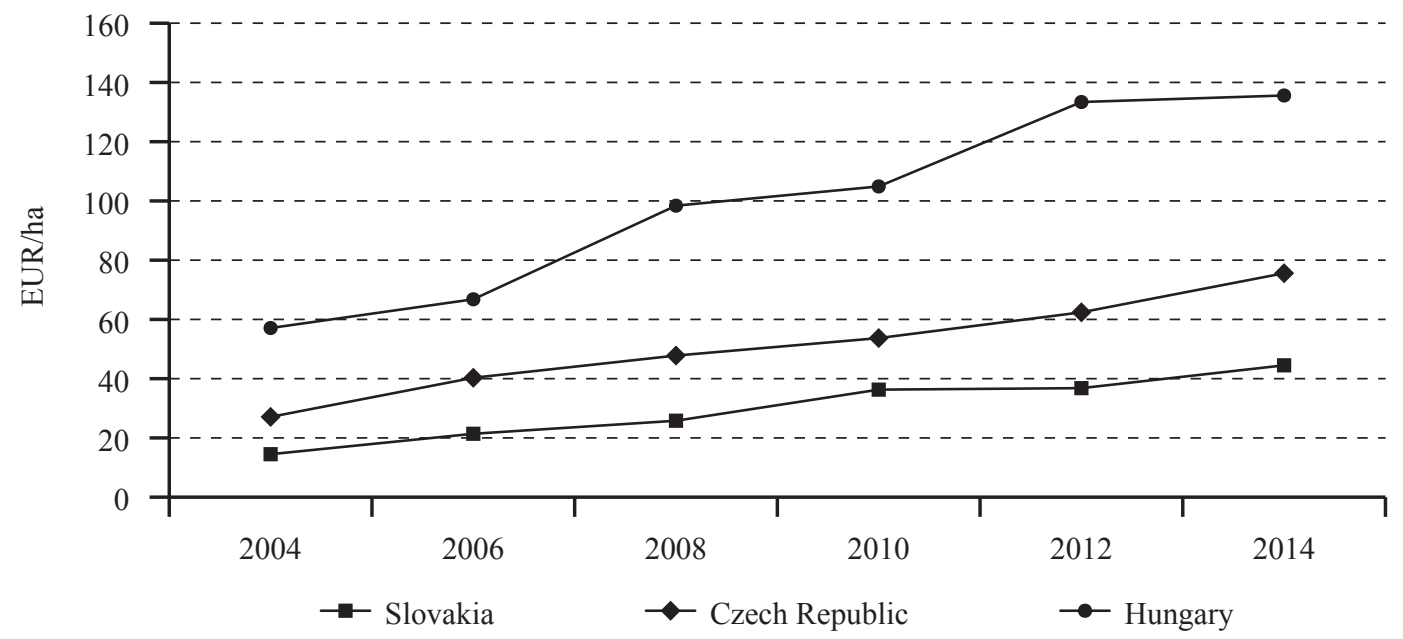

Source: Eurostat, VUZE, VUEPP, HCSO, FADN

The market price of agricultural land, EUR 2,760 per hectare in 2014, i.e. more than double the average Slovak price of land designated for agricultural use in the long term, is at present and in particular compared to the EU 15 countries relatively low. It is fair to assume that the prices of agricultural land in the Czech Republic will grow in the coming years. The economic recession stagnated the land market, both in terms of the volume of land transfers and the price level. Agricultural companies and cooperatives have the biggest shares of the land purchased. The market prices of agricultural land grew by 52.3 per cent from 2004 compared to 2012 and reached in the first half of 2013 average price levels of EUR 2,500 per hectare in Klatovy, EUR 3,100 per hectare in Havlíčkův Brod and EUR 3,600-3,800 per hectare in Znojmo and Olomouc.

The average land rental fee was EUR 75.6 per hectare in 2014, having almost tripled from 2004 (Figure 3). The highest average rental fee in 2012 was recorded in beet-growing and maize growing areas: EUR 89.9 per hectare and EUR 78.2 per hectare respectively in the case of legal persons and EUR 70.6 per hectare and EUR 77.7 per hectare respectively in the case of natural person tenants. The average rental fee was the lowest for natural person tenants in potato growing (EUR 39.0 per hectare) and in mountain areas (EUR 29.7 per hectare).

On the Hungarian land market yearly trade is balanced, with inheritance at around 200-210 thousand hectares per year on average, that is 2.5-3.0 per cent of all land changing hands. Land sale is hindered by the fact that land is an important and traditional form of safeguarding and increasing wealth, and therefore market sales are minimal. The average land price, EUR 2,809 per hectare in 2014, was a little higher than the average price in the Czech Republic. The average rental fee of EUR 135.6 in 2014 was threefold that of the Slovak and 1.8 fold that of of the Czech average fee. Despite 
the fact that since the accession to the EU land prices have more than doubled and the land rental fees have almost tripled, the prices are still lagging behind those prevailing in the 'old' EU Member States. Location, infrastructure and land quality determine land prices and rents. In land prices between regions, even 12 fold differences could be found from poor quality (EUR 700 per hectare) to excellent quality (EUR 8,600 per hectare) agricultural land in 2013 (Table 3).

In land rents within regions, 3-4 fold differences occur between the best and the worst quality of arable lands; in the Northern Great Plain even almost sevenfold differences can be found. In most parts of Hungary arable land of average and good land quality can be rented for EUR 80-210 per hectare. Arable land rents for excellent quality land are the highest (EUR 150-397 per hectare) in the Northern Great Plain and in the Southern Transdanubian regions. At the county level, the highest prices are in Hajdú-Bihar (EUR 3511 per hectare) and Györ-Moson-Sopron (EUR 3321 per hectare), and the lowest the price in Nógrád (EUR 1139 per hectare). The average rental fee is also the highest in Hajdú-Bihar county (EUR 178,5 per hectare) and the lowest in Nógrád county (EUR 60 per hectare).

Table 3: Arable land prices in Hungary by land quality and regions, 2013.

thousand EUR/ha

\begin{tabular}{lcccc}
\hline \multicolumn{1}{c}{ Region/land quality } & Poor & Average & Good & Excellent \\
\hline Central Hungary & $1.0-2.4$ & $2.1-3.5$ & $2.8-5.2$ & $3.5-6.2$ \\
\hline Central Transdanubia & $1.4-2.8$ & $1.6-3.5$ & $2.2-4.3$ & $3.5-5.5$ \\
\hline Western Transdanubia & $1.2-3.1$ & $2.6-4.5$ & $2.8-5.5$ & $2.9-7.6$ \\
\hline Southern Transdanubia & $1.2-3.1$ & $1.4-4.7$ & $2.1-5.9$ & $3.3-6.9$ \\
\hline Northern Hungary & $0.7-1.2$ & $1.0-3.1$ & $1.6-4.1$ & $1.7-4.5$ \\
\hline Northern Great Plain & $1.2-3.8$ & $1.7-5.2$ & $2.2-6.2$ & $2.8-8.6$ \\
\hline Southern Great Plain & $0.9-2.1$ & $1.4-2.4$ & $1.7-3.8$ & $2.8-6.9$ \\
\hline
\end{tabular}

Remark: Land quality expressed in Golden Crown (GC) value (under 17 GC; 17-25 GC; 25-30 GC above 30 GC) per hectare.

Source: Based on data from the National Food Chain Safety Office, 2014

Beyond regulations, transaction costs also apply on the land market to influence efficient allocation of land. Land taxes (sales capital profit tax, registration tax and real estate tax) also play an important role in the market participants' decisions to sell, buy and own agricultural land. In Slovakia, the tax on agricultural land is regulated by Act No. 582/2004 Coll.. The taxpayer under this Act is the owner of the land, the administrator of state-owned land or the administrator of land owned by municipality. The taxpayer is the natural person or legal person with allocated plots of land from the land fund used by a legal person until completion of land consolidation or it is a tenant, if the land tenancy lasts at least five years and the tenant is registered in cadastre or the tenant, who administrate the land of Slovak land fund. The tax for arable land is based on the value of the land. In 2012 the average amount of tax on agricultural land was highest in Nitra region (EUR 29,8 per hectare) and the lowest in Banská Bystrica region (EUR 9,1 per hectare) (Table 4).

In the Czech Republic, tax income from agricultural land is regulated by Act No. 338/1992 Coll. The taxpayer is the owner of the plot. For land owned by the Czech Republic the taxpayer is a state organisation, unless specified otherwise, or a government organisation established under special legislation or a legal person who has the right to permanent use or the right of permanent use has changed to a loan under a special legal prescription. The taxpayer on leased land is normally the lessee of the land. The tax is 0.75 per cent of the official price of the agricultural land in the appropriate cadastral area. 
Table 4: Average amount of tax of agricultural land in Slovakia, 2008-2012.

\begin{tabular}{lrrr} 
& & & EUR/ha \\
\hline Rrnava & $\mathbf{2 0 0 8}$ & $\mathbf{2 0 1 0}$ & $\mathbf{2 0 1 2}$ \\
\hline Nitra & 22.15 & 33.12 & 28.55 \\
\hline Žilina & 32.05 & 29.58 & 29.84 \\
\hline Banská Bystrica & 5.40 & 7.75 & 7.04 \\
\hline Prešov & 12.59 & 10.42 & 9.1 \\
\hline Košice & 14.54 & 8.61 & 10.11 \\
\hline Total & 13.26 & 14.17 & 11.04 \\
\hline
\end{tabular}

Source: Research Institute of Geodesy and Cartography, Research Institute of Agricultural and Food Economics

In Hungary land is generally exempt on tax. In the case of lending a 16 per cent tax applies on the land lease fee. However, based on Act CXVII. of 1995, rental income revenues from land leasing contracts exceeding five years are exempt from tax. So far, only 13 settlements have been introduced land tax, which is paid by the owner of the land. Land tax is around EUR 15-30 per hectare per year. There is a local government levy of the full amount of land tax only non-resident land owners, while local residents have a 90 per cent discount.

Although official data on foreign investments in agricultural holdings usually do not exist, because of the low land prices and presence of large-scale farms with concentrated land use, large corporate farms in Slovakia, the Czech Republic and Hungary were exposed to domestic and foreign investors to a large extent.

In Hungary, foreigners only officially bought 700 ha of agricultural land between 2005 and 2006, which represents less than 0.2 per cent of the total turnover. The share of foreigners is slightly larger when it comes to buying farmsteads: between one percent and 1.5 per cent of the farmsteads that changed ownership were bought by foreigners. These low figures seem to indicate that foreigners do not really pose a threat to land purchase opportunities for Hungarian farmers. Nevertheless, the above figures only refer to official statistics. Many agricultural land parcels are sold using so-called 'pocket contracts', which were illegal but used. According to land experts, foreigners currently could use around 400 thousand ha, almost 8.7 per cent of total UAA, including land bought in an official or an unofficial way (TNI, 2013).

In the Czech Republic, where foreigners can buy agricultural land relatively easily according to a survey carried out by the Czech Union of Agricultural Businesses, in 2006 foreigners owned 90 thousand ha of agricultural land (or 2.1 per cent of all agricultural land) and rented around 400 thousand ha, corresponding to 9.5 per cent of all agricultural land. In Slovakia, according to land experts, foreigners currently can use around 200 thousand hectares, 11 per cent of total UAA.

\section{Future land policy}

In Hungary, land policy gives preference to the establishment and development of family farms The number of preferred family size farms increased by 71 per cent since the millennium and their average area by 10 per cent. Land concentration will continue with dynamic land use structure change in the longer term. Family farms might initiate land acquisition. The land acquisition of owners of large capital intensive farms might also be realised. In the land policy it is still a challenge to encourage investments and concentration process for the development of the labour-intensive sectors. Besides the New Land Act, in accordance with the Basic Law the acts on farm regulation and production organisation will bring under regulation. These regulations to be created in the future 
might include further special rules on land ownership and use. The introduction of farm regulation might lead to the dissemination and development of family farming and result in the further forcing back of large farms.

In Slovakia, present forms of management will strengthen the position of the company at the expense of cooperatives. The average area of and the share of cultivated area in commercial farms of individuals will slightly increase. The priority in terms of the future configuration of the business structure will be economically justified size and production structure of the legal form of business. The size structure of farms will influence the future routing of the CAP i.e. presented routing support (financial prioritisation of small farms), support of organic food cultivation and raw materials for biofuels). The municipal policy will differentially affect the development, size structure and economic stabilisation of the business of primary producers. Its real power (e.g. tax policy, agribusiness local support and tackling unemployment and so on) will affect the extent of diversification of production towards non-agricultural activities, in particular services, and it can significantly support the level of economic activity, in particular in the less developed regions.

In the Czech Republic, digitalisation of cadastre and clearly knowing the ownership of plots of agricultural land is one of actual solved problems. The second is the land consolidation, which would help to solve the problems of land ownership fragmentation.

\section{Conclusions}

Investment in agriculture will occur primarily where land prices are low and farm structures are concentrated. National land policies have different aims in the three countries, due to the diversity in farm structures. Their common feature is to assist in meeting the land demand of efficient farms, moderate land fragmentation and to regulate or intervene directly to stimulate or obstruct land concentration.

Hungary decided to support family farming as part of its national land policy with limiting domestic and foreign investments occurring in agriculture. This will reduce land concentration, slow down structural change and land price and rental fee development, but strengthen the positions of family farms on the land and rental markets. The next step for Hungarian land policy is to establish the legal framework for establishing model farms which, based on their qualifications, experience and positive impacts, could become the driving force of Hungarian agriculture.

The introduction of a free land market in Slovakia and in the Czech Republic will stimulate investments in agriculture leading to structural change and land price and rental fee growth in the middle term. Higher prices might induce further land sales, increasing land concentration and eliminating the problems arising from land fragmentation. Czech and Slovak land policies also focus on strengthening the economic position of the current farmers, on creating legislative conditions for the purchase of agricultural land and on assisting young farmers to start farming. 


\section{Annex}

\section{Abbreviations}

\begin{tabular}{|c|c|}
\hline AKI PÁIR & AKI Market Price Information System \\
\hline AKI & Research Institute of Agricultural Economics, Budapest, Hungary \\
\hline APA & Agricultural Paying Agency \\
\hline ARDA & Hungarian Agricultural and Rural Development Agency \\
\hline ARDOP & Agricultural and Rural Development Operational Programme \\
\hline AWU & Annual Work Unit \\
\hline BPS & Basic Payment Scheme \\
\hline CAP & Common Agricultural Policy \\
\hline CEECs & Central and Eastern European Countries \\
\hline CNDP or top-up & Complementary National Direct Payments \\
\hline Comecon & Council for Mutual Economic Assistance \\
\hline COP crops & Cereals, oilseeds and protein crops \\
\hline $\mathrm{CR}$ & Concentration Ratio \\
\hline $\mathrm{CZK}$ & Czech koruna \\
\hline CZ-NACE & Classification of Economic Activities \\
\hline CZSO & Czech Central Statistical Office \\
\hline EAA & Economic Accounts of Agriculture \\
\hline EAFRD & European Agricultural Fund for Rural Development \\
\hline EAGF & European Agricultural Guarantee Fund \\
\hline EAGGF & European Agricultural Guidance and Guarantee Fund \\
\hline EBIT & Earning Before Taxes \\
\hline $\mathrm{EC}$ & European Commission \\
\hline EFA & Ecological Focus Area \\
\hline EIP-Agri & European Innovation Partnership for Agricultural Productivity and Sustainability \\
\hline EP & European Parliament \\
\hline EU & European Union \\
\hline EUR & Euro \\
\hline $\mathrm{F} \& \mathrm{~V}$ & Fruit and Vegetable Sector \\
\hline FADN & Farm Accountancy Data Network \\
\hline FDI & Foreign Direct Investment \\
\hline FIFG & Financial Instrument for Fisheries Guidance \\
\hline FSS & Farm Structure Survey \\
\hline FTE & Full Time Equivalent \\
\hline GAEC & Good Agricultural and Environmental Condition \\
\hline GC & Golden Crown \\
\hline GDP & Gross Domestic Product \\
\hline GM & Genetically Modified \\
\hline GNI & Gross National Income \\
\hline GVA & Gross Value Added \\
\hline $\mathrm{HCSO}$ & Hungarian Central Statistical Office \\
\hline HUF & Hungarian Forint \\
\hline IAEI & Institute of Agricultural Economics and Information, Prague, Czech Republic \\
\hline LDS & Local Development Strategy \\
\hline LFS & Labour Force Survey \\
\hline LU & Livestock Unit \\
\hline
\end{tabular}




$\begin{array}{ll}\text { MARD } & \text { Ministry of Agriculture and Rural Development, Hungary } \\ \text { MPO } & \text { Marketing Producer Organisations } \\ \text { MPRV SR } & \text { Ministry of Agriculture and Rural Development of the Slovak Republic } \\ \text { MRD } & \text { Ministry of Rural Development, Hungary } \\ \text { MSs } & \text { Member States } \\ \text { MZe } & \text { Ministry of Agriculture of the Czech Republic } \\ \text { NA } & \text { National Accounts } \\ \text { NAV } & \text { National Tax and Customs Administration of Hungary } \\ \text { NHRDP } & \text { New Hungary Rural Development Plan } \\ \text { NPPC-VÚEPP } & \text { National Agricultural and Food Centre - Research Institute of Agricultural } \\ & \text { and Food Economics, Bratislava, Slovak Republic } \\ \text { PDO } & \text { Protected Designation of Origin } \\ \text { PGI } & \text { Protected Geographical Indication } \\ \text { PLs } & \text { Private Labels } \\ \text { R\&D } & \text { Research and Development } \\ \text { RDP } & \text { Rural Development Plan } \\ \text { ROA } & \text { Return on Assets } \\ \text { ROE } & \text { Return on Equity } \\ \text { ROS } & \text { Return On Sales } \\ \text { SAPARD } & \text { Special Accession Programme for Agriculture and Rural Development } \\ \text { SAPS } & \text { Single Area Payment Scheme } \\ \text { SFS } & \text { Small Farmers Scheme } \\ \text { SKK } & \text { Slovak koruna } \\ \text { SMEs } & \text { Small and Medium-sized Enterprises } \\ \text { SMP } & \text { Skimmed Milk Powder } \\ \text { SMR } & \text { Statutory Management Requirements } \\ \text { SO SR } & \text { Statistical Office of the Slovak Republic } \\ \text { SOP ARD } & \text { Sectoral Operational Programme Agriculture and Rural Development } \\ \text { SZIF } & \text { State Agricultural Intervention Fund } \\ \text { TSG } & \text { Traditional Specialty Guaranteed } \\ \text { UAA } & \text { Utilised Agricultural Area } \\ \text { VCS } & \text { Voluntary Coupled Support } \\ \text { WMP } & \text { Whole Milk Powder } \\ & \\ & \end{array}$




\section{References}

1. AAM Group (2013): Az Új Magyarország Vidékfejlesztési Program III-IV. tengely négy hatásindikátorának mérése. (Measurement of the four impact indicator of NHRDP AXIS 3 and 4.) p. 56.

2. AKI (2014): ÚMVP I. tengelyes hatásindikátorok meghatározása. (Measurement of impact indicators of of NHRDP AXES 1.) p. 33.

3. Association of vinedressers SR (2013): Employment is the result and not the cause. Farming newspapers no. 6

4. Baptista, R.D. (2012): Technological transition and the new skills required by the agribusiness sector. International Food and Agribusiness Management Review, Special Issue A, 5, 105-109.

5. Béládi, K. and Kertész, R. (2010): A termelési méret szerepe a fontosabb mezőgazdasági ágazatok eredményességében a tesztüzemek adatai alapján (2006-2008). Agrárgazdasági Tanulmányok. AKI. Budapest. pp. 88.

6. Béládi, K. and Kertész, R. (2013): A szántóföldi növények költség- és jövedelemhelyzete. In: A főbb mezőgazdasági ágazatok költség- és jövedelem helyzete 2011. Agrárgazdasági Információk.

7. Biró, Sz., Dudás, Gy., Fieldsend, A., Fogarasi, J., Hamza, E., Miskó, K., Kürthy, Gy., Potori, N., Rácz, K., Tikász, I., Tóth, O., Vágó, Sz., Varga, E. and Varga, E. (2016): 'Research for AGRI Committee - Farm structural change in Central and Eastern Europe and the CAP' (pp. 79-196) in: Research for AGRI Committee - Structural change in EU farming: How can the CAP support a 21 st century European model of agriculture? Brussels: Policy Department B: Structural and Cohesion Policies, European Parliament. (ISBN 978-92-823-8818-1)

8. Biró, Sz. (ed.), Székely, E. (ed.), Hamza, E., Molnár, A., Rácz, K., Tóth, K., Tóth, O. and Varga E. (2012): A mezőgazdasági foglalkoztatás bővítésének lehetőségei vidéki térségeinkben. (Opportunities to increase employment in agriculture in the rural areas of Hungary.) Budapest: Agrárgazdasági Kutató Intézet.

9. Biró, Sz. and Rácz, K. (2014): Hatékonyság és foglalkoztatás a magyar mezőgazdaságban. Gazdálkodás 56 (4), 376-383.

10. Blaas, G. and Varošćák, J. (2006): Slovak agricultural markets and farm income after the EU accession. AGRIC. ECON. - CZECH 52 (1), 23-29.

11. Brooks, K. and Nash, J. (2002): The rural sector in transition economies, in Garrdner, B. and Rausser, G. (eds.), Handbook of agricultural economics. Vol. 2. Amsterdam: Elsevier. http://dx.doi.org/10.1016/s1574-0072(02)10012-0

12. Buchta, S. (2005): Regional aspects of the SAPARD programme implementation in the Slovak Republic. AGRIC. ECON. - CZECH 51 (12), 539-546.

13. Cerna, P. (2005): National review on the SAPARD Programme in the Czech Republic. Prague: EUROPEUM Institute for European Policy.

http://pdc.ceu.hu/archive/00004256/01/SAPARD_report.pdf

14. Chavas, J. (2001): Structural Change in Agricultural Production: Economics, Technology and Policy, in Gardner, B. and Rausser, G. (eds.), Handbook of Agricultural Economics, NorthHolland: Elsevier, 264-282. http://dx.doi.org/10.1016/s1574-0072(01)10008-3

15. Chevassus-Lozza, E., Majkovic, D., Persillet, V. and Unguru, M. (2005): Technical Barriers to Trade in the European Union: Importance for the New EU Members. An Assessment for Agricultural and Food Products. In: Drabik, D. - Pokrivcak, J. - Ciaian, P. (2007): Trade Creation and Diversion in the Enlarged EU Market: Evidence for Agricultural Trade in Slovakia. Finance a Úvěr - Czech Journal of Economics and Finance, 57, 2007, no. 9-10.

16. Ciaian, P., Kancs, d'A., Swinnen, J., van Herck, K. and Vranken, L. (2012): Sales Market Regulations for Agricultural Land in EU Member States and Candidate Countries. Factor Markets No. 14, February 
17. Czerván, Gy. - Hungarian Ministry of Agriculture (2015): Basic payments and young farmers scheme. (Alaptámogatás és a fiatal gazdák kiegészítő támogatása.) Agrya Conference, Budapest, 27.02.2015.

http://www.agrya.hu/sites/default/files/downloads/1._czervan_gyorgy.pdf (Accessed 10.03.2015.)

18. Darvasné, Ö.E., Székelyhidi, K., Felkai, B.O. and Szabó, D. (2014): Az Európai Uniós és nemzeti élelmiszerminőség-rendszerek és védjegyek helyzete Magyarországon. Agrárgazdasági Könyvek, Agrárgazdasági Kutató Intézet, p. 161.

19. Davidova, S., Bailey, A., Dwyer, J., Erjavec, E., Gorton, M. and Thomson, K. (2013): Semisubsistence farming: value and directions of development, European Parliament, Policy Department B: Structural and Cohesion Policies.

http://www.europarl.europa.eu/RegData/etudes/etudes/join/2013/495861/IPOL-AGRI_ ET(2013)495861_EN.pdf

20. DHV CR, spol. s r.o. a TIMA Liberec, s.r.o. (2013): On-going evaluation of the Rural Development Programme for the Czech Republic 2007-2013. Final report. (In Czech.)

21. Dudek, M., Chmieliński, P., Karwat-Woźniak, B. and Wrzochalska, A. (2014): Human capital in the structural transformation process of rural areas and agriculture. Warsaw: Institute of Agricultural and Food Economics - National Research Institute (IERIGZ).

22. EC (2001): SAPARD: How the Multi-annual Financing Agreement works. MEMO/01/106 26/03/2001. http://europa.eu/rapid/press-release_MEMO-01-106_en.htm?locale=hu

23. EC (2010): Europe 2020 - A strategy for smart, sustainable and inclusive growth. Communication from the Commission, COM (2010) 2020 final.

24. EC (2012a): Evolution of the market situation and the consequent conditions for smoothly phasing-out the milk quota system - second ,soft landing” report. Brussels: European Commission, October 2012.

25. EC (2012b): Agriculture in the European Union, Statistical and Economic Information, Report 2012. Brussels: European Commission, December 2012.

26. EC (2013a): Annex to the Communication from the Commission to the Council and the European Parliament. Technical adjustment of the financial framework for 2014 in line with movements in GNI. (Article 6 of Council Regulation No 1311/2013 laying down the multiannual financial framework for the years 2014-2020)

27. EC (2013b): How many people work in agriculture in the European Union? EU Agricultural Economics Briefs. Brussel: European Commission.

28. EC (2014): Direct payments - Decisions taken by Member States by 1 August 2014. Presentation at the 5th Meeting of the Expert Group on Monitoring and Evaluating the CAP, 14.10.2014. DG Agriculture and Rural Development, European Commission.

http://ec.europa.eu/transparency/regexpert/index.cfm?do=groupDetail. groupDetailDoc\&id=16267\&no=4 [Accessed 16.03.2015].

29. EC (2015a): The CAP towards 2020 - Implementation of the new system of direct payments MS notifications. DG Agriculture and Rural Development, European Commission.

http://ec.europa.eu/agriculture/direct-support/direct-payments/docs/implementation-msnotifications-slides_en.pdf

30. EC (2015b): Rural Development 2014-2020 Country Files. http://ec.europa.eu/agriculture/rural-development-2014-2020/country-files/

31. EC DG AGRI (2002a): Situation in the candidate countries. Country Report on the Czech Republic. http://ec.europa.eu/agriculture/external/enlarge/publi/countryrep/czech.pdf

32. EC DG AGRI (2002b): Situation in the candidate countries. Country Report on the Slovak Republic. http://ec.europa.eu/agriculture/external/enlarge/publi/countryrep/slovak.pdf

33. EC DG AGRI (2002c): Situation in the candidate countries. Country Report on Hungary. http://ec.europa.eu/agriculture/external/enlarge/publi/countryrep/hungary.pdf 
34. EC DG AGRI (2010): Agriculture in the European Union. Statistical and economic information. http://ec.europa.eu/agriculture/agrista/2010/table_en/2010enfinal.pdf

35. EC DG AGRI (2013): Agriculture in the European Union. Statistical and economic information. http://ec.europa.eu/agriculture/statistics/agricultural/2013/pdf/full-report_en.pdf

36. EC DG AGRI (a): EU agriculture - Statistical and economic information. http://ec.europa.eu/agriculture/statistics/agricultural/index_en.htm

37. EC DG AGRI (b): Distribution of direct aid to farmers.

http://ec.europa.eu/agriculture/cap-funding/beneficiaries/direct-aid/index_en.htm

38. Ecsediné, Wanek Zs., Egri, E., Elek, R., Isépy, A., Kálmán, Á., Mándi-Nagy, D., Stummer, I. (ed.) and Tikász, I.E. (2013): A fontosabb termékpályák piaci folyamatai 2012. Agrárgazdasági Információk. Agrárgazdasági Kutató Intézet, Budapest.

39. Ecsediné, Wanek Zs., Egri, E., Elek, R., Isépy, A., Kálmán, Á., Mándi-Nagy, D., Stummer, I. (ed.) and Tikász, I.E. (2014): A fontosabb termékpályák piaci folyamatai 2013. Agrárgazdasági Információk. Agrárgazdasági Kutató Intézet, Budapest.

40. European Council (2013): Multiannual Financial Framework - Conclusions. Brussels, 8 February 2013, EUCO 37/13

41. European Parliament (EP) (2013): European Council Conclusions on the Multiannual Financial Framework 2014-2020 and the CAP.

42. Eurostat (2014): Farm Structure Survey 2013.

43. Eurostat (2015): Agriculture, forestry and fishery statistics. 2015 edition. p. 204.

44. Eurostat (2016): Unemployment statistics 2016.

http://ec.europa.eu/eurostat/statistics-explained/index.php/Unemployment_statistics

45. Evangelos, N. (2010): Agriculture in post-transition CEECs: reconstruction or deconstruction? Journal of Economics and Business XIII (1)

46. Evenson, R. (2002): Technology and Prices in Agriculture. In: Consultation on Agricultural Commodity Price Problems. Commodities and Trade Division. Food and Agriculture Organization of the United Nations. Rome, 25-26 March 2002.

47. F.O. Licht (2015): Weak crude oil changes biofuels feedstock use patterns. Published: 21 July 2015 12:39 PM

https://www.agra-net.com/agra/world-ethanol-and-biofuels-report/opinion/weak-crude-oilchanges-biofuels-feedstock-use-patterns-485576.htm

48. Feldman, Zs. - Hungarian Ministry of Agriculture (2015): Voluntary Coupled Support 20152020. (Termeléshez kötött támogatás 2015-2020.) Agrya Conference, Budapest, 27.02.2015. http://www.agrya.hu/sites/default/files/downloads/2._feldman_zsolt.pdf

49. Fertő, I. and Varga, Á. (2013): Vidékkutatás 2012-2013. A vidékfejlesztési programok hatásai. (Rural Research 2012-2013. The effects of rural development programs.) Budapest: MTA Közgazdasági és Regionális Tudományi Kutatóközpont

50. Futó, Z. and Sárvári, M. (2015): A kukorica termesztés technológiájának fejlesztési lehetőségei. Szent István Egyetemi Kiadó, Gödöllő.

51. GFK (2013): A magyar háztartások kedvelik a tejet. HáztartásPanel, 2013. 5. 25.

52. Györe, D., Popp, J., Stauder, M., and Tunyoginé, N.V. (2009): Az élelmiszer-kiskereskedelem beszerzési és árképzési politikája. Agrárgazdasági Tanulmányok 10, Agrárgazdasági Kutató Intézet, p. 129.

53. Halmai, P. and Vásáry, V. (2007): Transformational Crisis, Transformational Depression, The Changing Agriculture the Hungarian Case in Agricultural economics and transition: What was expected, what we observed, the lessons learned Proceedings. (Volume I) A Joint IAAE-EAAE Seminar September 6-8, 2007, Corvinus University of Budapest (CUB) Budapest, Hungary

54. Hartvigsen, M. (2015): Experiences with Land Consolidation and Land banking in Central and Eastern Europe after 1989. FAO Land Tenure Working Paper series, Rome: Food and Agriculture Organization of the United Nations 
55. HCSO (2011): Farm Structure Survey 2010.

56. HCSO (2014): Farm Structure Survey 2013.

57. Hungarian Dairy Producer and Inter-branch Organization (2013): Situation of the Hungarian dairy Sector and development trends. Budapest: Hungarian Dairy Producer and Inter-branch Organization.

58. Hungarikum konzorcium (2010): Az Új Magyarország Vidékfejlesztési Program (2007-2013) félidei (Mid-Term) értékelése. Zárójelentés 1-4. fejezetek, 2010. december, p. 54.

59. ISAMM Communication No. 07. 2014. 07 Voluntary Coupled Support - Implementation - Decision of Member States Financial discipline. ISAMM CM - v. 1.27.8 branches/1.27/ IsammCtm-r3970 - nvasarmi - 01/08/2014 13:09 Disclaimer

60. Juhász, A., Darvasné, Ö.E. and Jankuné, K.Gy. (2010): Minőségi rendszerek szerepe a hazai élelmiszergazdaságban. Agrárgazdasági Könyvek, Budapest: Agrárgazdasági Kutató Intézet, p. 177.

61. Kapronczai, I. (2010): A magyar agrárgazdaság az adatok tükrében az EU csatlakozás után. Agrárgazdasági Tanulmányok 12. Budapest: AKI, p. 185.

62. Kapronczai, I., Kovács, H. and Varga, E. (2006): Mezőgazdasági termelők alkalmazkodása a beruházások és a foglalkoztatás aktuális kihívásaihoz. Statisztikai Szemle, 84. évfolyam 8. szám

63. Kapronczai, I. (ed.), Bojtárné, L.K., Felkai, B.O., Györe, D., Kürti, A., Székelyné, R.É., Tóth, P. and Vágó, Sz. (2009a): Tulajdonosi és szervezeti változások a hazai élelmiszeriparban. Agrárgazdasági Tanulmányok 1. Budapest: Agrárgazdasági Kutató Intézet, p. 136.

64. Kapronczai, I. (ed.), Bojtárné, L.K., Felkai, B.O., Gáborné, B.A., Székelyné, R.É., Tóth, P. and Vágó, Sz. (2009b): Az élelmiszerfeldolgozó kis- és középvállalkozások helyzete, nemzetgazdasági és regionális szerepe. Agrárgazdasági Tanulmányok 9. Budapest: Agrárgazdasági Kutató Intézet, p. 130.

65. Kartali, J. (2009): A hazai élelmiszer-kiskereskedelem struktúrája, különös tekintettel a kistermelők értékesítési lehetőségeire. Agrárgazdasági Könyvek, Budapest: Agrárgazdasági Kutató Intézet, p. 138.

66. Körtáj Tervező Iroda (2013): Az ÚMVP környezeti indikátorainak értékelése. (Evaluation of NHRDP environmental indicators.)

67. Kovács, G. (ed.), Czárl, A., Kürthy, Gy. and Varga, T. (2009): Az agrártámogatások hasznosulása. [The efficiency of agricultural subsidies.] Budapest: AKI.

68. Kovács, K., Magócs, K. and Bihari, Zs. (2005): Planning and implementing the SAPARD Program in Hungary, in SAPARD Review in Bulgaria, Czech Republic, Estonia, Hungary, Latvia, Poland and Romania, Impact analysis of the agriculture and rural development. European Institute Foundation, Bulgaria.

http://www.europeum.org/doc/publications/SAPARD_book_eng.pdf

69. Krrístková, Z. and Golová, A. (2011): Modelling direct payments to agriculture in a CGE Framework - analysis of the Czech Republic. Agricultural Economics (Zemědělská ekonomika) 57 (11), 517-528.

70. Liefert, W.M. and Swinnen, J. (2002): Changes in agricultural markets in transition economies. Agricultural Economic Report 806, ERS, USDA.

71. Macours, K. and Swinnen, J. (2000): Causes of Output Decline in Economic Transition: The Case of Central and Eastern European Agriculture. Journal of Comparative Economics 28 (1), 172-206. http://dx.doi.org/10.1006/jcec.1999.1643

72. Managing Authority of NHRD (2015): Jelentés a Darányi Ignác Terv - Új Magyarország Vidékfejlesztési Program végrehajtásának 2014. évi előrehaladásáról. Kecskemét, 2015. június

73. Márkusz, P. and Tóth, E. (2010): A szociális földprogramok szerepe a hátrányos helyzetủ vidéki népesség megélhetésében. Kertgazdaság 1. 
74. MARD of SR (2015): Rural Development Programme of the Slovak Republic 2007-2013. 7th RDP revision.

75. Marton, L. Cs., Berzy, T., Pintér. J., Spiktó, T., Tóthné, Zsubori Zs., Szőke, Cs., Nagy, Z. (2015). Kukoricanemesítés Martonvásár módra. Agrofórum Extra. 62. pp. 48-50.

76. Mathijs, E. and Mészáros, S. (1997): Privatisation and Restructuring of Hungarian Agriculture, in: Swinnen, J.F.M., Buckwell, A. and Mathijs, E. (eds.), Agricultural Privatisation, Land Reform and Farm Restructuring in Central and Eastern Europe, Ashgate, Aldershot, 161-188. http://dx.doi.org/10.1017/s0956793300001849

77. Matthews, A. (2012): The political feasibility of CAP redistribution. http://capreform.eu/the-political-feasibility-of-cap-redistribution

78. Mezera, J., Němec, R. and Špička, J. (2014a): Support of strengthening the cooperation and efficiency factors acceleratin innovation processes in the food industry. Agricultural Economics 60 (7), 295-300. ISSN 1805-9295.

79. Mezera, J., Němec, R. and Špička, J. (2014b): The aspects of investment in the food industry. The International Scientific Conference INPROFORUM 2014 - Investment Decision-Making in the Period of Economic Recovery, Faculty of Economics, University of South Bohemia in České Budějovice, Czech Republic. Book of proceedings, November 6-7, 2014, 88-94. ISBN978-80-7394-484-1.

80. Michalek, J. and Zarnekow, N. (2012): Application of Rural Development Index to Analysis of Rural Regions in Poland and Slovakia. Social Indicators Research 105, 1-37. http://dx.doi.org/10.1007/s11205-010-9765-6

81. Ministerstvo zemědělství (2006): Final report on the Sapard Programme in the Czech Republic. http://eagri.cz/public/web/file/17671/Zaverecna_zprava_SAPARD_AJ_web_pdf

82. Molnár, A. (ed.), Hamza, E., Székely, E. and Varga, E. (2011): Az EU társfinanszírozásával megvalósuló főbb vidékfejlesztési intézkedések átfogó értékelése. (Comprehensive assessment of the main EU co-financed rural development measures.) Agrárgazdasági Tanulmányok, Budapest: Agrárgazdasági Kutató Intézet, p. 101.

83. MPRV SR (2009): Rural Development Programme of the Slovak Republic 2007-2013. 2nd RDP revision., Dec. 2009.

84. MPRV SR (2014): Report on Agriculture and Food Sector in the Slovak Republic 2013.

85. MPRV SR (2015a): RDP - Financing Slovak agriculture, food and rural development in the programming period 2014 - 2020, March 2015

86. MPRV SR (2015b): Rural Developing Programme 2014 - 2020 - presentation, March 2015

87. MPRV SR and RIAFE (2008): Final Report. Ex-post evaluation of the Rural Development Plan of the Slovak Republic 2004-2006.

88. MRD (Vidékfejlesztési Minisztérium) (2010): Záró Végrehajtási Jelentés az Agrár és Vidékfejlesztési Operatív Program megvalósításáról. (ARDOP Final Report.) AVOP MB írásbeli eljárás, 2010. március 3.

89. MRD (Vidékfejlesztési Minisztérium) (2013a): J/13214. számú jelentés az agrárgazdaság 2012. évi helyzetéröl. (Report on agriculture, 2012.) I-II. kötet. 2013. november, Budapest.

90. MRD (Vidékfejlesztési Minisztérium) (2013b): Jelentés a Darányi Ignác Terv-Új Magyarország Vidékfejlesztési Program végrehajtásának 2012. évi előrehaladásáról. (NHRDP 2012 report.) 2013. június, Budapest.

91. MZe (2009): Horizontal rural development plan of Czech Republic. Annual progress reports for the years 2008. (In Czech.)

92. MZe (2010): Annual report of Operational Programme Rural Development and Multifunctional Agriculture in the Czech Republic. Praha: Fond EAGGF - Guidance section. (In Czech.)

93. MZe (2013): Panorama potravinářského průmyslu 2013 [Panorama of the food industry]. http://eagri.cz/public/web/file/352133/Panorama_potravinarskeho_prumyslu_2013.pdf 
94. NAFC, EuroConsulting, ltd. (2015): Annual Progress Report on the RDP 2007-2013 of the SR for 2014.

95. OECD (2005): Agricultural Policies in OECD countries: Monitoring and Evaluation 2005. Part II - Country Chapters. AGR/CA/APM (2005)5 Paris. 25-28 April 2005.

http://dx.doi.org/10.1787/agr_oecd-2005-en

96. OECD (2011), Fostering Productivity and Competitiveness in Agriculture, OECD Publishing. http://dx.doi.org/10.1787/9789264166820-en

97. OECD (2012): OECD Economic Surveys, Poland. Paris: OECD. http://dx.doi.org/10.1787/eco_surveys-pol-2012-en

98. OECD and FAO (2014): Agricultural Outlook 2014-2023. OECD Publishing. http://dx.doi.org/10.1787/agr_outlook-2014-en

99. Pepó, P. (2002): A hazai őszibúza-termesztés helyzete és fejlesztési lehetőségei. Gyakorlati Agrofórum. Volume 13. Number 9. 2-5. p.

100. Pepó, P. (2012): Kockázatok a repcetermesztésben. Agrofórum. Volume 23. Number 8. 12-19. p.

101. Pohlová, K. and Mezera, J. (2014): Analysis of Development of Czech Foreign Trade in Foods and Beverages. Agris on-line Papers in Economics and Informatics VI (4), 121-131.

102. Popp, J. and Potori, N. (2009): A főbb állattenyésztési ágazatok helyzete. Agrárgazdasági Tanulmányok, Budapest: Agrárgazdasági Kutató Intézet, p. 137.

103. Potori, N., Chmieliński, P. and Karwat-Woźniak, B. (2014): A comparison of the agro-food sectors in Poland and Hungary from a macro perspective. [In: Structural changes in Polish and Hungarian agriculture since EU accession: lessons learned and implications for the design of future agricultural policies. Potori, N. - Chmieliński, P. - Fieldsend, A. (ed.)] Agricultural Economics Books. 8-32.

104. Potori, N. (ed.), Biró, Sz., Bögréné Bodrogi, G., Kovács, M., Kozak, A., Mándi-Nagy, D., Molnár, A., Papp, G., Popp, J., Rácz, K., Radóczné Kocsis, T. and Székely, E. (2012): Közös Agrárpolitika 2014-2020: A reformtervezetek alapján várható hatások és kihívások Magyarországon. (The Common Agricultural Policy 2014-2020: Expected impacts and challenges for Hungary based on the reform proposals.) Budapest: Agrárgazdasági Kutató Intézet, p. 78.

105. Potori, N. and Nyárs, L. (2007): EU integration experiences of the agro-food sectors in Hungary, in: Czartoryski, W. (ed.), Changes in the food sector after enlargement of the EU. Warszawa: IERIGZ-PIB, 94-121.

106. Potori, N., Fieldsend, A.F., Garay, R., Popp, J. and Udovecz, G. (2011): The impacts of the global financial and economic crisis on the agro-food sector of Central and Eastern European and Central Asian countries. Studies in Agricultural Economics 113, 5-32.

107. Potori, N., Kovács, M. and Vásáry, V. (2013a): A közvetlen támogatások új rendszere Magyarországon 2014-2020 között: kötelező elemek és a döntéshozók mozgástere. [The new direct payment system in Hungary during 2014-2020: Mandatory measures and options for decision makers.] Gazdálkodás 57, 323-331.

108. Potori, N., Kovács, M. and Vásáry, V. (2013b): The Common Agricultural Policy 2014-2020: an impact assessment of the new system of direct payments in Hungary. Studies in Agricultural Economics 115 (3), 118-123. http://dx.doi.org/10.7896/j.1318

109. Rácz, K. (2013): Szegénységkezelés aktív eszközökkel? Egy produktív szociálpolitikai program két évtizedes müködésének tapasztalatai, in Kovács, K. and Váradi, M.M. (eds.), Hátrányban vidéken. Budapest: Argumentum Kiadó, 135-155.

110. Respect Tanácsadó és Szolgáltató Kft. (2009): Nemzeti Vidékfejlesztési Terv 2004-2006 ex-post értékelése, zárójelentés. Budapest, 2009. március 24.

111. RIAFE (2009): Final Report. Ex-post evaluation of the SAPARD Programme in the SR. Oct. 2009. 
112. Snower, D. J. (1994): The Low-Skill, Bad-Job Trap. International Monetary Fund Working Paper 83. p. 15.

113. Swinnen, J. and Knops, L. (eds.) (2013): Land, Labour and Capital Markets in European Agriculture, Centre for European Policy Studies (CEPS). Brussels.

114. Swinnen, J. and Vranken, L. (2009): Land and EU Accession: Review of the Transitional Restrictions by New Member States on the Acquisition of Agricultural Real Estate, CEPS Paperback. Brussels: CEPS, p. 104.

115. Szajner, P. and Vöneki, É. (2013): Recent developments in the dairy sector in Poland and Hungary, in Potori, N., Chmieliński, P. and Fieldsend, A.F. (eds), Structural changes in Polish and Hungarian agriculture since EU accession: lessons learned and implications for the design of future agricultural policies. Budapest: AKI.

116. Szanyi, M. (2013): Large-Scale Transformation of Socio-Economic Institutions - Comparative Case Studies on CEECs, Background Paper 3: Varieties of Capitalism and CEECs Work Package 105, MS23 "Interim report on comparative country studies" Working Paper no19. WWW for Europe project.

117. Székely, E. (2009): Nemzedékváltás a mezőgazdaságban. Agrárgazdasági információk (2), Budapest: Agrárgazdasági Kutató Intézet, p. 66.

118. Tallage (2015): Strategie Grains. Supply \& Demand Balance Sheets. http://www.strategie-grains.com/content_raw-materials-consumption_1530

119. Tanító, D. (ed.), Lámfalusi, I. (ed.), Felkai, B.O., Péter, K., Tóth, K. and Varga, T. (2013): A mezőgazdasági és az élelmiszeripari termékekre vonatkozó áfarendszer és -mérték változása és hatásai. Agrárgazdasági Könyvek, Budapest: Agrárgazdasági Kutató Intézet, p. 110.

120. Tikász, I.E. and Varga, E. (2015): Főbb szemes termények piaca. Manuscript.

121. TNI (2013): Land concentration, land grabbing and people's struggles. Take Action Against Land Grabbing in Europe, Transnational Institute for European Coordination Via Campesina and Hands off the Land network.

122. Varga, E., Aliczki, K., Garay, R., Mándi-Nagy, D., Nagy, L. and Vőneki, É. (2013): A Magyar mezőgazdaság főbb ágazatainak helyzete, piaci kilátásai rövid és középtávon. Agrárgazdasági Tanulmányok. Agrárgazdasági Kutató Intézet, Budapest. p. 172.

123. Vőneki, É., Mándi-Nagy, D. and Stark, A. (2015): Prospects for the European Union and Hungarian dairy sectors after the abolition of the milk quota system. Studies in Agricultural Economics 117. 1-9. http://dx.doi.org/10.7896/j.1424

\section{Acts/Regulations}

1. Act No. $10 / 2006$ Coll. On Social Cooperatives

2. Act No. 40/1964 On Civil Code Coll. as amended by later regulations

3. Act No. $75 / 2010$ on simplified employment

4. Act No. 95/1999 Coll. On the transfer of agricultural and forest land from state ownership to another person and to amend Act No. 569/1991 Coll.

5. Act No. 122/2013 Coll. On agricultural and forestry land turnover

6. Act No. 140/2014 Coll. On the acquisition of the property of the agricultural land and on amendments of certain acts

7. Act No. 219/1995 Collection of Laws

8. Act No. 220/2004 Coll. On Protection and Use of Agricultural Land

9. Act No. 229/1991 Coll. as amended

10. Act No. 252/1997 Collection of Laws

11. Act No. 299/1991 Coll. On land

12. Act No. 312/2004 Col. On Foreign Exchange Art. 2 and Art. 19a

13. Act No. 334/1992 Collection of Laws

14. Act No. 338/1992 Coll. On real estate tax 
15. Act No. 503/2012 Coll. On the State Land Office

16. Act No. 504/2003 Coll. On the lease of agricultural land, farm and forest land and on amendments of certain acts

17. Act No. 513/1991 Col. as amended by later regulations of the Commercial Code

18. Act No. 582/2004 Coll. On local taxes and fees for municipal waste and minor construction waste

19. Commission Regulation (EC) No 447/2004 of 10 March 2004 laying down rules to facilitate the transition from support under Regulation (EC) No 1268/1999 to that provided for by Regulations (EC) Nos 1257/1999 and 1260/1999 for the Czech Republic, Estonia, Latvia, Lithuania, Hungary, Poland, Slovenia and Slovakia

20. Commission Regulation (EC) No 595/2004 of 30 March 2004 laying down detailed rules for applying Council Regulation (EC) No 1788/2003 establishing a levy in the milk and milk products sector

21. Commission Regulation (EU) No 808/2014 of 17 July 2014 laying down rules for the application of Regulation (EU) No 1305/2013 of the European Parliament and of the Council on support for rural development by the European Agricultural Fund for Rural Development (EAFRD)

22. Council Regulation (EC) No 1257/1999 of 17 May 1999 on support for rural development from the European Agricultural Guidance and Guarantee Fund (EAGGF) and amending and repealing certain Regulations

23. Council Regulation (EC) No 1268/1999 of 21 June 1999 on Community support for preaccession measures for agriculture and rural development in the applicant countries of central and eastern Europe

24. Council Regulation (EC) No 1290/2005 of 21 June 2005 on the financing of Rural Development in the CAP

25. Council Regulation (EC) No 1698/2005 of 20 September 2005 on support for rural development by the European Agricultural Fund for Rural Development (EAFRD)

26. Council Regulation (EC) No. 73/2009 of 19 January 2009 establishing common rules for direct support schemes for farmers under the common agricultural policy and establishing certain support schemes for farmers, amending Regulations (EC) No. 1290/2005, (EC) No. 247/2006, (EC) No. 378/2007 and repealing Regulation (EC) No. 1782/2003

27. Council Regulation (EU) No. 1305/2013 of the European Parliament and of the Council of 17 December 2013 on support for rural development by the European Agricultural Fund for Rural Development (EAFRD) and repealing Council Regulation (EC) No 1698/2005

28. Council Regulation (EU) No. 1306/2013 of the European Parliament and of the Council of 17 December 2013 on the financing, management and monitoring of the common agricultural policy and repealing Council Regulations (EEC) No. 352/78, (EC) No. 165/94, (EC) No. 2799/98, (EC) No. 814/2000, (EC) No. 1290/2005 and (EC) No. 485/2008

29. Council Regulation (EU) No. 1307/2013 of the European Parliament and of the Council of 17 December 2013 establishing rules for direct payments to farmers under support schemes within the framework of the common agricultural policy and repealing Council Regulation (EC) No. 637/2008 and Council Regulation (EC) No. 73/2009

30. Council Regulation (EU) No. 1308/2013 of the European Parliament and of the Council of 17 December 2013 establishing a common organisation of the markets in agricultural products and repealing Council Regulations (EEC) No. 922/72, (EEC) No. 234/79, (EC) No. 1037/2001 and (EC) No. 1234/2007

31. Government Decision No. 1323/2012 on Swine strategy

32. Government Regulation no. 342/2014 Coll.: Government Regulation laying down the rules for aid in agriculture for Schemes of decoupled direct payments.

33. Government Regulation no. 36/2015 Coll.: Slovak Government Regulation on conditions for granting subsidies in agriculture in the form of coupled payments. 